\title{
Allenamides: A Powerful and Versatile Building Block in Organic Synthesis
}

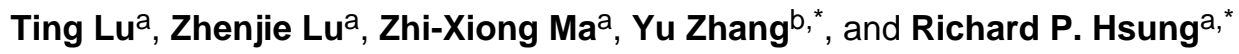 \\ aDivision of Pharmaceutical Sciences, School of Pharmacy, University of Wisconsin, Madison, WI \\ 53705

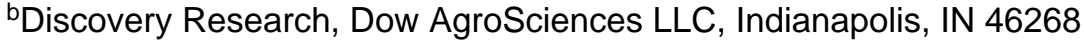

\section{Introduction}

In the past four decades, allenes have progressively risen from an unenviable status of being a structural curiosity to becoming one of the most powerful and versatile synthetic building blocks in organic synthesis. ${ }^{1-3}$ Although the focal theme of this review is centered on chemistry of allenamides, a proper introduction would need to commence with allenamines. Allenamides are functionally derived from allenamines, ${ }^{4}$ which along with structurally related systems such as allenol ethers ${ }^{5}$ and allenyl sulfides, ${ }^{6}$ can be classified as heteroatomsubstituted allenes. Allenamines have been known for more than forty years since the first documentation of their preparations and characterizations in 1968 by Viehe. ${ }^{7}$ It is noteworthy that Viehe was at the time developing a based-catalyzed isomerization of propargyl amines as a useful protocol for synthesizing ynamines (Scheme 1), which had just come onto the scene as a useful synthetic building block. ${ }^{8-10}$ Allenamines were postulated as an intermediate en route to ynamines in this prototropic isomerization that follows essentially the zipper-type mechanism.

The $\pi$-donating ability of nitrogen atom renders allenamines more electron-rich than simple allenes, thereby predisposing them to electrophilic activations. An electronic bias can be exerted through delocalization of the nitrogen lone pair toward the allenic moiety as demonstrated in the resonance form of allenamines. Accordingly, highly regioselective transformations can be achieved with consecutive addition of electrophiles and nucleophiles (Scheme 2). In addition to aforementioned regiochemical control, allenamines also offer a number of other advantages over simple allenes. The trivalent nature of the nitrogen atom allows: (1) Tethering of a chirality-inducing unit for providing stereochemical induction; concomitantly with the inclusion of a coordinating unit to provide conformational rigidity; (2) a much greater flexibility in designing intramolecular reactions or tandem processes than with oxygen- or sulfur-substituted allenes; and last but not the least, (3) a novel entry to alkaloids if the nitrogen atom can be preserved throughout the entire transformative sequence. Moreover, intramolecular reaction manifolds as shown with a possible diastereoselective cyclopropanation reaction (Scheme 2) can greatly manifest these remarkable features, particularly the latter two. Therefore, while the chemistry of other

\footnotetext{
”To whom correspondence should be addressed. yzhang9@dow.com, rhsung@wisc.edu.
} 
heteroatom-substituted allenes is of high impact and value to organic synthesis, allenamines should prove to be more attractive for developing stereoselective methodologies as well as rapid assembly of structural complexity. ${ }^{1,2}$

Without illustrating any specifics here on allenamine chemistry given all the comprehensive reviews, ${ }^{1,2}$ elegant precedents adopting allenamines in a range of transformations have indeed been documented to further support their synthetic potential and provoke interest from the synthetic community. Unfortunately, further developments had been severely thwarted because allenamines are also highly sensitive toward hydrolysis with a tendency to polymerize even at low temperatures (Scheme 3), thereby creating serious difficulties in their preparation and experimental handling. ${ }^{1,2}$ Consequently, the great potential of chemistry of nitrogen-substituted allenes could only be partially realized. Therefore, efforts to identify an allenamine-equivalent should be of high significance if it can strike the right balance between stability and reactivity.

Toward this end, allenamides should represent ideal candidates as a stable allenamineequivalent. Delocalization of the nitrogen lone-pair into the electron-withdrawing amido group should diminish its donating ability toward the allenic moiety, thereby leading to improved stability (Scheme 4). In short, the very simple fact that allenamides can champion an extra resonance form speaks volume of its superior stability over allenamines. It could be a great story if allenamides were a result of some clever design in search for a stable allenamine-equivalent. However, this is not true and the story is much less dramatic. Allenamides have co-existed along side of allenamines for all of the last four plus decades after Dickinson's first preparation and concise characterizations of 1,2-propadienyl-2pyrrolidinone in 1967 (Scheme 5). ${ }^{11}$

In fact, Dickinson coined the term "allenamide" to describe 1,2-propadienyl-2-pyrrolidinone based the analogy of using enamides ${ }^{17}$ for Stork's $N$-acylated enamines. To clarify reports by $\mathrm{Cho}^{12}$ and others, ${ }^{13}$ Dickinson concisely demonstrated that treatment of 2-pyrrolidinone with $\mathrm{NaH}$ and propargyl bromide had indeed led to the allenamide as the major and stable product also via the same prototropic isomerization pathway. Intriguingly, unlike Viehe's work, allenamide did not undergo further isomerization to the respective ynamide, although with further treatment of $\mathrm{NaOMe}$ and pyrrolidine, ynamide was postulated as an intermediate en route to the $N$-acyl-pyrrolidine product. Nevertheless, this documentation of ynamide actually predated Viehe's 1972 account, ${ }^{14}$ and chemistry of ynamides has indeed generated an immense amount of interest from the synthetic community in the last 15 years. ${ }^{15,16}$

To align with the history, our foray into this field coincides with both of Viehe and Dickinson's work. In search of a useful synthetic method to construct chiral ynamides 16 years ago, ${ }^{10}$ we found that based-catalyzed prototropic isomerization of propargyl amides reliably arrested at the allenic stage and gave none of the desired ynamides ${ }^{10}$ (Scheme 6) regardless of nature of the base used, temperature, and solvents (also see Schemes 24 and 25 vide infra). More importantly, to properly acknowledge a critical person in our entire endeavor in allenamide chemistry, I owe everything to the very first postdoctoral research fellow in my group, Dr. Lin-Li Wei [Ph.D. with Professor Teck-Peng Loh at National 
University of Singapore]. Dr. Wei, who was working on these isomerizations, pointed out that these allenamides that she had obtained could prove to be an excellent allenamineequivalent, and evolve into highly versatile synthetic building blocks in organic synthesis.

Given the precedent, the ease of preparation, and stability, the most critical question would be whether these allenamides could possess sufficient reactivity. A survey of the literature indicates that although it was far from a blank page, allenamides have been much less explored relative to allenamines. ${ }^{4,18-20}$ Precise reasons are not very clear, but there were very few citations on synthesis and applications of allenamides before 1989. While few more reports appeared from late 1980's to mid-1990's, the real outburst in chemistry of allenamides came 16 years ago, just as we also became deeply involved in the development of allenamide chemistry. Such sustained emergence strongly suggests that allenamides have set the gold standard for balancing reactivity and stability. They are becoming proven allenamine-equivalents that can be employed in a diverse array of stereoselective and intramolecular reactions that were not possible with traditional allenamines. They represent the ideal platform for pushing the limit of synthetic potential of nitrogen-substituted allenes.

It is the purpose of this review to provide proper illustrations of the elegant chemistry involving allenamides that has come to pass, thereby eliciting a greater amount of interests from the synthetic community to create new allenamide chemistry. Lastly, this perspective that advancement of any field requires collective creativity and innovation from many people and not just a few individuals rings hollow here. On that note, although we are trying our very best to be comprehensive, it is likely that we have inadvertently missed some beautiful work for which we express our regret here in advance.

\section{Preparation}

\subsection{Historical Examples}

Besides Dickinson's first allenamide synthesis ${ }^{11}$ (Scheme 5), Bogentoft ${ }^{21}$ reported another earlier example of allenamide synthesis (Scheme 7). Allenamide 2 was prepared in 50\% yield via a base-induced isomerization of propargyl amide 1. Per-hydrogenation of allenamide $\mathbf{2}$ was also reported to give alkyl amide 3 . In addition, under basic conditions, a mixture of oxazole $\mathbf{4}$ and oxo-quinazoline $\mathbf{6}$ could be obtained via C-O (pathway $a$ ) and C-N (pathway $b$ ) bond formation, respectively, from a ring-opened intermediate 5 .

In 1976, Corbel $^{22}$ achieved the first synthesis of an acyclic allenamide 8 also via the base induced isomerization of $N$-propargyl phosphoramidate $[\mathrm{X}=\mathrm{OEt}] /$ phosphoramide [X $=$ $\left.\mathrm{NMe}_{2}\right] 7$ (Scheme 8). Ynamide $\mathbf{9}^{15}$ was found along with $\mathbf{8}$, as a mixture when $\mathrm{X}=\mathrm{NMe}_{2}$.

\subsection{Sigmatropic Rearrangement}

Balasubramanian's ${ }^{23}$ syntheses of benzimidazolyl thiazoles 12 represents the first applications of [3,3]-sigmatropic-rearrangement in allenamide synthesis (Scheme 9). Although not isolated, allenamides $\mathbf{1 1}$ were postulated as intermediates to 12 through [3,3]sigmatropic rearrangements of benzimidazolyl propargylic sulfides $\mathbf{1 0}$. 
Balasubramanian ${ }^{24}$ also found that de-propargylation occurred when bis-propargyl thiol benzimidazole 13 was refluxed in HMPT to afford benzimidazolyl thiazole 17 (Scheme 10). However, when heated in non-polar solvents, polymerization products were observed, presumably through allenamide $\mathbf{1 4}$ resulting from the initial [3,3]-sigmatropic rearrangement, albeit not isolated.

Overman ${ }^{25}$ discovered that allenamides $\mathbf{1 9}$, a secondary allenamide, could be isolated through an Overman-Claisen rearrangement of propargyl trichloroacetimidates 18 (Scheme 11). Allenamides $\mathbf{1 9}$ could be further isomerized to $1 Z-3 E$-dienamides 20 in a highly stereoselective manner via 1,3-H shift from the $\gamma$-substituent.

Padwa ${ }^{26 a}$ found that when heating oxazole 21a in a benzene-pyridine solution, 4oxazolin-2-one derived allenamide $\mathbf{2 1 b}$ was obtained in high yield via an aza-Claisen rearrangement (Scheme 12). This very much reminiscences chiral allenamides later on reported by Hsung (see Scheme 6).

Very Recently, Anderson ${ }^{26 \mathrm{~b}}$ reported a related rearrangement in the synthesis of a- $(\mathrm{N}-2-$ pyridonyl)ketones $\mathbf{2 3}$ via an $\mathrm{Au}(\mathrm{III})$ catalyzed tandem amination-hydration reaction from propargyloxypyridines $\mathbf{2 2}$. The formation of allenamides $\mathbf{2 2 c}$ was the result of a formal azaClaisen rearrangement of $\mathbf{2 2 a}$.

More recently, Mapp ${ }^{27}$ cleverly designed a facile synthesis of allenamides 28 via palladiumcatalyzed [3,3]-sigmatropic rearrangement of propargyl phosphorimidates 27 generated from propargyl alcohols $\mathbf{2 4}$, chlorophosphite $\mathbf{2 5}$, and azide $\mathbf{2 6}$ (Scheme 13). With this method, an array of mono-, di-, and trisubstituted allenamides were obtained in good yields. When optically pure alcohols $\mathbf{2 4}$ [see $\mathbf{c}-\mathbf{d}$ ] were used as precursors, chiral allenamides 28 [see $\mathbf{c}-\mathbf{d}$ ] could be prepared with a high level of chirality transfer. It is noteworthy that formally with two electron-withdrawing substituents on the nitrogen atom, these are allen-imide equivalents.

$\mathrm{Lu}$ and Wang ${ }^{28 \mathrm{a}}$ reported the isolation of $N$-phosphoryl allenamides $\mathbf{3 1}$ from propargyl alcohol 29 through an $\mathrm{Yb}(\mathrm{III})$-catalyzed Meyer-Schuster type rearrangement ${ }^{29 \mathrm{a}}$ followed by trapping with $N$-tolyl phosphoroamidate $\mathbf{3 0}$ (Scheme 14).

Very recently, Carbery ${ }^{30}$ attempted to prepare allenamides $\mathbf{3 4}$ via Ireland-Claisen rearrangements ${ }^{29 b}$ of ynamide ${ }^{15}$-derived silyl ketene acetal 33 (Scheme 15). However, they obtained Z-2-amido diene $\mathbf{3 5}$ only, presumably through a facile decarboxylationisomerization sequence from allenamides $\mathbf{3 4}$ after the rearrangement.

Tamura $^{31}$ reported the first example of [2,3]-sigmatropic rearrangement of sulfimine 38, leading to allenamide 39 (Scheme 16). The rearranged precursor 38 was obtained by acylating the propargyl sulfide $\mathbf{3 6}$ with $N$-triflate carbamate $\mathbf{3 7}$.

Van Vranken ${ }^{32}$ demonstrated that a range of allenamides $\mathbf{4 2}$ could be synthesized in moderate to high yields by a Fe(II)-catalyzed tandem $S$-imidation/[2,3]-sigmatropic rearrangement of the possible ironnitrene intermediates 41 (Scheme 17). 
Armstrong ${ }^{33}$ showed that allenamides $\mathbf{4 6}$ could be prepared from propargyl sulfides 43 in an analogous manner but using oxaziridine $\mathbf{4 4}$ (Scheme 18). This reaction also proceeds through a related cascade Simidation/[2,3]-sigmatropic rearrangement sequence, under metal-free conditions with propargyl sulfimides $\mathbf{4 5}$ as a possible intermediate.

Armstrong ${ }^{34}$ later synthesized allenamides $\mathbf{5 0}$ in high yields via a [2,3]-sigmatropic rearrangement of propargyl sulfimides $\mathbf{4 9}$, which were prepared in situ from propargyl sulfides 47 and amidation agent 48 (Scheme 19). Notably, optically enriched allenamides 50 [see a-d] were also achieved with effective transfer of chirality information from enantiomerically enriched propargyl sulfimides $\mathbf{4 7}$ [see $\mathbf{a}-\mathbf{d}$ ] .

\subsection{Base-Induced Isomerization}

2.3.1. Cyclic Propargyl Amides-Base-induced isomerization of propargyl amides represents a highly atom-economical synthesis of allenamides. Padwa ${ }^{35 a}$ first discovered that propargyl amide $\mathbf{5 1}$ and allenamide $\mathbf{5 2}$ could be interconverted at high temperature under basic conditions when they were investigating flash vacuum pyrolysis of $\mathbf{5 2}$ (Scheme 20).

Galons $^{35 b}$ reported another earlier example in which allenamides $\mathbf{5 5}$ were formed through a solid-liquid phase transfer catalyst-promoted reaction of imidazoles $\mathbf{5 3}$ with propargyl bromide 54 (Scheme 21).

$\mathrm{Radl}^{36}$ employed the base-induced isomerization method to synthesize quinolone-derived allenamides 57 by using $\mathrm{NaHCO}_{3}$ in aq EtOH solution (Scheme 22). Intriguingly, the desired isomerization product $57 \mathbf{c}$ was not attainable from the respective $N$-propargyl acridone under this isomerization condition.

Zemlicka ${ }^{37}$ documented syntheses of a series of nucleoside derived allenyl alcohols $\mathbf{5 9}$ through the base promoted isomerization of the corresponding 2-butynols 58 (Scheme 23). These nucleoside-derived analogues possess potential cytotoxic and antiviral activities. ${ }^{38}$

The $N$-propargylation-isomerization protocol for preparation of ynamide $\mathbf{6 3}^{15}$ from acridone $\mathbf{6 0}$ have been documented from several research groups. ${ }^{39}$ By slightly modifying previous propargylationisomerization protocol, ${ }^{39 a}$ Hsung ${ }^{40}$ prepared ynamide $\mathbf{6 3}^{15}$ from acridone $\mathbf{6 0}$ in two steps. However, they also found that by shortening the reaction time, allenamide $\mathbf{6 2}$ could be isolated in high yield as the isomerization intermediate ${ }^{41 a}$ (Scheme 24).

When extending this base-induced isomerization sequence to access a broader scope of ynamides $67,{ }^{15}$ Hsung ${ }^{41 \mathrm{a}}$ found that with $t$-BuOK as the base at room temperature, isomerization of propargyl amides 65 only provided allenamides 66 (Scheme 25). Consequently, a facile two-step protocol was established to prepare cyclic allenamides $\mathbf{6 6}$ from amides 64: ${ }^{41}$ (i) alkylation of amides 64 with propargyl bromide 54; and (ii) baseinduced isomerization to allenamides $\mathbf{6 6}$. With this protocol, chiral allenamides $\mathbf{6 6} \mathbf{e}-\mathbf{g}$ were accessible for the first time, and a large scale synthesis of chiral allenamide $66 \mathbf{g}$ was later documented. ${ }^{41 \mathrm{c}}$ 
Pellón ${ }^{42}$ found that this two-step protocol could be rendered in one-pot by heating the mixture of acridones 68 and propargyl bromide 54 in $\mathrm{KOH}$ aqueous/butanone solution with cetyltrimethylammonium bromide as the phase transfer catalyst (PTC) (Scheme 26). Without isolating the $N$-propargylated intermediate 69, acridone-derived allenamides $\mathbf{7 0}$ were isolated in good yields. It is noteworthy that these allenamides could not be prepared under Radl's conditions (Scheme 22). ${ }^{36}$

Plumet $^{43}$ also examined the base-induced two-step/one-pot operation using lactams 71 with different ring sizes $(n=1-5)$ (Scheme 27). They found that as the ring size increases, it is more difficult to obtain the desired isomerized products 73 .

Ishihara ${ }^{44}$ reported an $N$-alkylation of selenium-containing $\beta$-lactams $\mathbf{7 4}$ in their synthesis of a key intermediates en route to antibacterial agents (Scheme 28). A small amount of allenamide $\mathbf{7 7}$ was isolated in addition to propargyl amide 75. Both propargyl amide $\mathbf{7 5}$ and allenamide $\mathbf{7 7}$ could be cyclized to give selenacephem $\mathbf{7 6}$ and $\mathbf{7 8}$, respectively.

2.3.2. Acyclic Propargyl Amides-While propargylating $N$-allylsulfonamide 79, Meijere $^{45}$ obtained a mixture of allenamide $\mathbf{8 0}$ and propargyl amide $\mathbf{8 1}$ (Scheme 29).

Hsung ${ }^{46}$ examined base-induced isomerizations of acyclic propargyl amides 82 and reported the first successful isomerization of chiral propargyl amides to ynamides $\mathbf{8 4}$ (Scheme 30). ${ }^{15}$ Intriguingly, under the same reaction conditions, unlike propargyl amides 82c and 82d, urethanes such as $\mathbf{8 2} \mathbf{a}$ and $\mathbf{8 2 b}$ stopped at the first isomerization step to form allenamides 83a and 83b. Reasons for these contrasts are not clear at this point.

The base-promoted propargyl-allenamide isomerization was also observed in several metalcatalyzed reactions. Zhang and $\mathrm{Liu}^{47}$ found that besides their expected formal cycloaddition product lactam 86, the depropargylated amide $\mathbf{8 7}$ was also observed, probably via isomerization of Ag-acetylide $\mathbf{8 8}$ to allenamide $\mathbf{9 0}$ followed by a facile hydrolysis during quenching and work-up (Scheme 31). Although allenamide 90 was not isolated, it represents the most plausible intermediate that can explain the loss of the propargyl substituent.

\subsection{Elimination}

Tanaka $^{48 a}$ found that lactam-derived allenamides 92 could be obtained in high yields from enol triflates 91 through a $\mathrm{Et}_{3}$-promoted E2-elimination (Scheme 32). A similar $\mathrm{Et}_{3} \mathrm{~N}$ assisted elimination protocol was also applied in Farina's ${ }^{48 b}$ synthesis of lactam-derived allenamides 94 from their corresponding enol triflates 93.

Majumdar ${ }^{49}$ a reported preparation of $N$-enyne acrydone 97 under PTC conditions and cumulene-type allenamides 96 were proposed as intermediates (Scheme 33).

More recently, Fallis ${ }^{49 b}$ suggested that allenamide $\mathbf{1 0 0}$ [another secondary allenamide] was formed from aniline substituted propargyl phosphonium ether 98 via an initial intramolecular elimination of triphenylphosphine oxide followed by trapping the cumulene intermediate 99 (Scheme 34). 


\subsection{Amino-Cyclization}

Tamaru ${ }^{50}$ reported a Pd-catalyzed intramolecular cyclization of propargyl biscarbamates 101 to generate allenamides 103 that could further cyclize to 105 (Scheme 35). The unsymmetrical biscarbamates 106 afforded a mixture of different allenamides 107 and 108, from adducts 109 and 110, respectively. Ratios of 107 and 108 with different substituents suggested that the oxidative addition of $\operatorname{Pd}(0)$ prefers the less hindered propargyl carbon as shown in $\mathbf{1 0 9}$ (Scheme 36).

Mori $^{51 a}$ demonstrated that aminocyclization of $\beta$-lactam containing propargyl benzoate $\mathbf{1 1 1}$ could deliver allenamide $\mathbf{1 1 3}$ or enamide $\mathbf{1 1 5}$ in a selective manner depending on the ligand used (Scheme 37). When a monodentate ligand such as $\mathrm{P}-(o \text {-tolyl })_{3}$ was used, allenamide 113 with a carbapenam skeleton was isolated as the major product via the palladium intermediate 112. However, when the bidentate ligand such as dppf was used, enamide 115 was isolated as the sole elimination product from the palladium $\pi$-allyl complex $\mathbf{1 1 4}$.

Mori ${ }^{51 b}$ later reported this $\mathrm{Pd}(0)$-catalyzed intramolecular cyclization of propargyl ethercontaining amides using general $N$-sulfonyl substituted allenamides 117 (Scheme 38). When using the monodentate ligand $\mathrm{P}$ - $(o \text {-tolyl })_{3}$, for $\mathrm{R}=\mathrm{OTBS}$, allenamides 117 could be isolated; However, in the case when $\mathrm{R}=\mathrm{H}, 117$ further isomerized to dienamide 118. With dppf serving as ligand, depending on the substrates, enamides 120-122 could be obtained via nucleophilic addition and/or $\beta$-elimination pathways from palladium $\pi$-allyl complex 119 depending up substitutions ( $\mathrm{R}=\mathrm{H}$ versus OTBS).

\subsection{Trost-Hsung $\mathrm{N}$-Allenylations}

Trost $^{52}$ reported the synthesis of cyclic and acyclic allenamides 125 by a $\mathrm{Cu}(\mathrm{I})$-catalyzed C$\mathrm{N}$ bond formation between allenyl halides 124 and various amides 123 (Scheme 39). Dienamides $\mathbf{1 2 7}$ were occasionally isolated, which likely resulted from isomerization (or 1,3-H shift) of the initially formed allenamides $\mathbf{1 2 5}$.

At the same time, Hsung ${ }^{53}$ also independently documented a related $N$-allenylation (Scheme 40). More critically, various chiral allenamides 130 were synthesized via $\mathrm{Cu}(\mathrm{I})$-catalyzed stereospecific amidation of optically enriched allenyl halides such as $(M)$-128a [the $(P)$ enantiomer also led to the same result - enriched $(P)$-130a and $(P)$-130b, although not shown here]. ${ }^{54}$ Under these reaction conditions, chirality information of optically enriched allenyl halides was transferred with high fidelity.

Recently, Bäckvall ${ }^{55}$ disclosed similar protocols in which a series of $N$-sulfonyl substituted allenamides 136 were synthesized using bromoallenes 135 and sulfonamides 134 (Scheme 41). In the coupling between $N, N^{\prime}$-ditosyl-1,2-diaminobenzene 137 and bromoallene 135a, cyclized product $\mathbf{1 3 9}$ was obtained in $63 \%$ yield via the allenamide intermediate $\mathbf{1 3 8}$, thereby representing an intramolecular hydroamination of allenamides.

A general mechanism of this $\mathrm{Cu}(\mathrm{I})$-catalyzed cross-coupling reaction is shown in Scheme 42. Overall, the catalytic cycle starts from oxidative addition of $\mathrm{Cu}(\mathrm{I})$ onto haloallenes $\mathbf{1 3 5}$ to form $\mathrm{Cu}(\mathrm{III})$ intermediates $\mathbf{1 4 0}$, which could then undergo transmetallation with deprotonated amides to form $\mathbf{1 4 2}$. The subsequent reductive elimination would afford 
allenamides 136. From Hsung's work, this proposed catalytic cycle implies that the optical integrity of the allenic copper(III) intermediates 140 and 142 could be preserved throughout the amidation or the $\mathrm{N}$-alkenylation process.

\subsection{Suzuki-Miyaura Cross-Coupling}

Cao and Lai ${ }^{56}$ reported a-arylated allenamides 146 through the Suzuki-Miyaura crosscoupling ${ }^{57}$ between 1-alkoxycarbonyloxy allenamides 143 and arylboronic acids 145 (Scheme 43). Allenamides 146 could also be produced through couplings of 3alkoxycarbonyloxy ynamides 144 with arylboronic acids $\mathbf{1 4 5}$. A 1,3-aryl migration of the initially generated bulky ynamide intermediate 147 was proposed.

\section{Reactions of Allenamides}

\subsection{Deprotonations}

3.1.1. a-Deprotonation-Corbel ${ }^{22}$ documented the first example of a-deprotonation of allenamide 148 to generate the lithiated allenamide 149, which was trapped by electrophiles to afford a-substituted allenamides 150 (Scheme 44). Subsequent hydrolysis of 150 resulted in the corresponding unsaturated ketones 151.

Hsung ${ }^{58}$ later reported a regioselective a-deprotonation of allenamides 152 using $n$ - BuLi (Scheme 45). The one-pot deprotonation/alkylation sequence can be widely applicable to access a series of a-substituted allenamides 153, $\gamma$-deprotonation product 154 was not observed.

3.1.2. $\gamma$-Deprotonation- Corbel $^{22}$ demonstrated that trisubstituted allenamide 156 could be obtained from a-substituted allenamide $\mathbf{1 5 5}$ through a $\gamma$-deprotonation/trapping sequence (Scheme 46). Allenamide $\mathbf{1 5 6}$ could also undergo hydrolysis to afford substituted unsaturated ketone 157.

Hsung ${ }^{58}$ reported that when using $t-\mathrm{BuLi}$ as the base, the protonation had no $\mathrm{a} / \gamma$ selectivity as revealed after $\mathrm{D}_{2} \mathrm{O}$ quench, leading to a 50:50 mixture of 153 and 154 (Scheme 47).

However, the deprotonation $/ \mathrm{D}_{2} \mathrm{O}$ trapping sequence of allenamide 158 with the a-position blocked would occur at $\gamma$-position to afford 159 with moderate diastereoselectivity.

\subsection{Addition Reactions}

3.2.1. Hydroalkoxylation-Horino ${ }^{59}$ found that hydroalkoxylations of allenamide $\mathbf{1 6 0}$ with alcohol 161 could take place at both $\gamma$ (pathway $a$ ) and a (pathway $b$ ) positions to afford distal addition product 162 and proximal addition product 163, respectively (Scheme 48). With an $\mathrm{Au}(\mathrm{I})$ catalyst, hydroxylation of $\mathbf{1 6 0}$ could be achieved more selectively at the a position to give 163 in high yield. Diene 163 was subsequently used to construct spiro dihydrofuran 164 through Ring-closing metathesis (RCM). In contrast, the distal addition product 162 was more favored under thermal conditions.

3.2.2. Hydro-Hydroxyalkylation-Krische ${ }^{60 a}$ cleverly designed an equivalent of aminoallylations of aldehydes via a Ru(II)-catalyzed stereoselective hydro- 
hydroxyalkylation of allenamide 165 to construct anti-1,2-amidoalcohols 167 (Scheme 49). More specifically, aminoallylations of aldehydes 166 with allenamide 165 were achieved in a highly stereoselective manner via the closed chair-like transition state 168. The hydrometalation of allenamides was achieved through the use of $\mathrm{Ru}(\mathrm{II})$-catalyst with $\mathrm{Cy}_{3} \mathrm{P}$ serving as the ligand and $i-\mathrm{PrOH}$ as the hydrogen source.

Krische $^{60 \mathrm{~b}}$ further evolved this highly anti-selective hydro-hydroxyalkylation of allenamide 165 to prepare an array of anti-1,2-amidoalcohols 167 through the use of simple alcohols 169 (Scheme 50). The anti selectivity could be rationalized possibly via the same chair-like transition state formed through " $N u-E$ " pair 168, which involved complexation of the hydroruthenated allenamide intermediate with the aldehyde generated in situ from respective alcohols 169 via hydrogen transfer.

3.2.3. Hydroamination- $\operatorname{Radl}^{61}$ reported the preparation of a series of $\mathrm{N}$-2-oxo-propyl-4quinolones $\mathbf{1 7 3}$ from allenamides $\mathbf{1 7 0}$ via an initial hydroamination reaction using primary or secondary amines 171. Subsequent hydrolysis of the enamine intermediate 172 [not isolated] during the work-up would lead to $\mathbf{1 7 3}$ (Scheme 51). It is noteworthy that the regioselectivity of this hydroamination appears to be opposite from what one would have been predicted based on the general resonance structure of allenamides (see Scheme 2). That is, the nucleophilic amino group landed on the more electron rich central allenic carbon. This could be regarded as an umpolung addition.

Broggini ${ }^{62}$ reported an $\mathrm{Au}(\mathrm{III})$-catalyzed intramolecular hydroamination of allenamides 174, which afforded a mixture of cis- and trans 2-vinylimidazolidines 177 through the 5-exo-trig transition states 175 and 176, respectively. Intriguingly, when $\mathrm{R}=\mathrm{Bn}$, only cis-177 was isolated in good yield (Scheme 52). Although authors did not provide details, cis- and trans 2-vinylimidazolidines 177 likely came from cyclizations through $\mathrm{Au}(\mathrm{II})$-complexes $\mathbf{1 7 5}$ and 176, respectively [carbamate tautomers were drawn to show clarity].

Broggini ${ }^{63}$ also found that allenamides $\mathbf{1 7 4}$ could be subjected to base promoted intramolecular hydroamination, leading to heterocycles 178, 179 and/or 180 (Scheme 53). In most cases, the cyclization occurs effectively with microwave irradiation at the central allenic carbon to afford $\mathbf{1 7 9}$, thereby representing another umpolung addition. However, no hydroamination products were observed when $\mathrm{R}=\mathrm{Ph}$. Instead, at room temperature $\mathbf{1 8 1}$ was obtained via $\mathrm{C}-\mathrm{C}$ bond formation through the transition state $\mathbf{1 8 2}$.

In a clever design of enamide synthesis, Kimber ${ }^{64}$ reported stereoselective hydroaminations of allenamides 183 with anilines 184 under $\mathrm{Au}(\mathrm{I})$-catalyzed conditions to afford $E$-enamides 185 via intermediates 186 (Scheme 54).

Broggini 65 evolved their hydroamination method into the palladium-catalyzed intramolecular carboamination of allenamides for the synthesis of 4-imidazolidinones 189 and 191 (Scheme 55). In this work, they employed optically enriched $a$-amino allenamides 187, and the reaction proceeded through a palladium-catalyzed carbopalladation-5-exo-dig amination process via palladium $\pi$-allyl intermediates 188 or 190 [carbonylated]. It is 
noteworthy that this cascade worked well for intramolecular carbopalladation of allenamides en route to tricyclic fused-ring imidazolidinones such as $189 \mathrm{c}$ and $\mathbf{1 8 9 d}$.

Broggini ${ }^{66}$ further developed their carboamination and microwave-assisted hydroamination work using allenamides 192 that contains an indolyl unit (Scheme 56). Using 192, Styrylsubstituted indoloimidazoles derivatives 194 were synthesized through the intermediacy of palladium $\pi$-allyl complex 193 in which the trapping exclusively occurred at the internal allenic carbon by the indole nitrogen. In the presence of $\mathrm{CO}$, this cyclization cascade could afford indoloimidazoles 199. In addition, the authors found that the use of microwave was crucial in dictating the hydroamination pathway of 192. In particular, under the microwave activation, oxidative addition of the indolyl $\mathrm{NH}$ bond took place to give the $\mathrm{Pd}(\mathrm{II})$-complex 195. A subsequent hydride transfer or hydro-palladation would lead to the palladium $\pi$-allyl intermediate 196 and streamline the reaction pathway toward vinyl indoloimidazoles 197.

More recently, Broggini ${ }^{67}$ documented an $\mathrm{Au}(\mathrm{III})$-catalyzed intramolecular hydroamination of allenamides 200 to give 2-vinyl-4-quinazolinones 201 (Scheme 57). In addition, when switching to $\mathrm{Pd}(0)$ catalyst and along with ArI, the carboamination products 2-(astyryl)quinazolin-4-one derivatives $\mathbf{2 0 3}$ could again be produced with good yields.

Again, Bäckvall ${ }^{55}$ also has an example already shown in Scheme 41 (See $\mathbf{1 3 7} \rightarrow \mathbf{1 3 8} \rightarrow \mathbf{1 3 9}$ ) in Section 2.6.

3.2.4. Hydroarylation-Oishi, Fujii and Ohno ${ }^{68}$ developed the first gold-catalyzed intramolecular hydroarylation of allenamides 204 for the formation of dihydroquinolines 208 (Scheme 58). Mechanistically, the $\mathrm{Au}(\mathrm{I})$-coordinated allenamides 205 could undergo cyclization to form the vinyl-gold cation complex 206 via an intramolecular SE-Ar reaction. Upon deprotonation-rearomatization, the neutral vinyl gold complex 207 could undergo protodemetalation to form the dihydroquinoline products $\mathbf{2 0 8}$. For the unsymmetrical arenes, the regioselectivity was found to be ranging from moderate to excellent (see $\mathbf{2 0 8 c / 2 0 8 d}$ and 208g/208h).

Kimber ${ }^{69}$ reported a highly stereoselective hydroarylation of allenamides 209 to obtain a series of achiral and chiral oxazolidinone-derived $E$-enamides 211 via the 1,4-addition to $\mathrm{N}$ acyl iminium intermediates $\mathbf{2 1 0}$ (Scheme 59). This gold-catalyzed hydroarylation took place relatively faster than their Pd- and Ru-catalyzed counterparts. Bis-hydroarylation products could be obtained in some cases. For example, 209 reacted with furan twice through both 1,4- and 1,2-hydroarylation to give 211c. In another case, bis-hydroarylation afforded 211e when 2 equiv of $\mathbf{2 0 9}$ were used.

Kimber ${ }^{70}$ also unveiled an $\mathrm{Au}(\mathrm{I})$-catalyzed intramolecular hydroarylation of allenamides 212 for the construction of a-vinyl substituted tetrahydro isoquinolines 213 (Scheme 60). When $\mathrm{R}=$ Boc, the hydroarylation reaction was impeded presumably due to the steric hindrance of the bulky Boc group. On the other hand, these hydroarylations can be highly diastereoselective as shown with $\mathbf{2 1 3 c}$, which was isolated as a single diastereomer.

See Section 3.6.6. $[3+3]$ Formal Cycloadditions for another example. 
3.2.5. Hydroalkenylation-Takeda ${ }^{71}$ reported a titanocene(II)-promoted cross-coupling of allenamide 214, which could generate 1,4-dienes 217 regioselectively via the formation of the 2-alkylidenetitanacyclopentane complex 216 (Scheme 61). This process formally constitutes a hydroalkenylation [or hydrovinylation] of allenamides.

\subsubsection{Hydroacylation-See Section 3.3 Aldol Reactions.}

3.2.7. Cyano- and Boro-Acylations-Nakao and Hiyama ${ }^{72}$ discovered that with a $\mathrm{Ni}(0)$ catalyst, cyanoesterification of allenamide $\mathbf{2 1 8}$ could take place to afford highly functionalized $E$-enamide $\mathbf{2 2 0}$ with moderate yield as well as high regio-and stereoselectivity via the $\mathrm{Ni}(\mathrm{II})$-complex 221 (Scheme 62). The process constitutes a threecomponent coupling protocol with cyanoformate being generated in situ from chloroformate ester 219 and TMS-CN. Mapp ${ }^{27}$ also demonstrated that their de novo allenamide 28a (see Scheme 13) could be employed in a palladium-catalyzed regio- and stereoselective boroacylation of the terminal allenic olefin, leading to enamide 222 (Scheme 62).

3.2.8. Hydrostannylation-See Section 3.4.2. Palladium Catalyzed Cyclizations.

3.2.9. Silylstannylation—Rajanbabu ${ }^{73}$ found that highly functionalized $E$-silylenamides 224 could be obtained from allenamide 223 via a Pd-catalyzed silylstannylation in an excellent regio- and stereoselective manner (Scheme 63).

\subsection{Aldol Additions}

Seebach ${ }^{74}$ first demonstrated that in the presence of $\mathrm{TiCl}(i-\mathrm{PrO})_{3}$, lithiated chiral propargyl amides could undergo 1,2-additions to aldehydes in a stereoselective manner (Scheme 64). When chiral propargyl amide 225 was treated with $n$-BuLi and $\mathrm{TiCl}(i-\mathrm{PrO})_{3}$, and subsequently added to various aldehydes, an array of de novo $\gamma, \gamma$-disubstituted chiral allenamides 226 were obtained with high stereoselectivity. The excellent selectivity could be rationalized through a highly organized chair-like transition state shown in the propargylic titanium complex 227 after the transmetallation.

Hegedus ${ }^{75 a}$ found that transmetallating deprotonated chiral $\mathrm{N}$-propargyl-oxazolidinones with $\mathrm{MgBr}_{2}$ could produce de novo optically active $\gamma$-stannylated allenamide $\mathbf{2 3 0}$ through a highly stereoselective anti-SE2' process (Scheme 65). The presence of $\mathrm{MgBr}_{2}$ favors coordinated intermediates but with transition state $\mathbf{2 3 2}$ being preferred over 231, which suffers from syn-pentane like steric interaction. These authors subsequently developed an elegant application of these novel stannylated allenamides. Specifically, a $\mathrm{BF}_{3}-\mathrm{OEt}_{2}$ catalyzed aldol reaction between $\gamma$-stannylated allenamide $\mathbf{2 3 0}$ and various aldehydes afforded an array of $\beta$-hydroxylpropargyl amides $\mathbf{2 3 4}$ with high syn-stereoselectivity through the preferred open transition state $\mathbf{2 3 3}$.

Hegedus ${ }^{75 b}$ also found that in the presence of $\mathrm{BF}_{3}-\mathrm{OEt}_{2}$, the readily available oxiranes 236 could be the precursor in place of aldehydes (through a Lewis acid assisted alkyl, aryl or hydride-shift) for the aldol addition to chiral $\gamma$-stannylated allenamide 235 (Scheme 66). 
These reactions likely proceed through a similar open transition state as shown in $\mathbf{2 3 3}$ (Scheme 65), leading to $\beta$-hydroxyl propargyl amides 237 with high syn-stereoselectivity.

Hegedus ${ }^{76}$ later disclosed that optically active $\gamma, \gamma$-disubstituted allenamides $\mathbf{2 4 0}$ could be synthesized (Scheme 67). However, in this case, with the aid of 9-BBN derived organoboranes, high anti-stereoselectivity was achieved through the transition state shown in 239. This method proves to be an excellent stereochemical complement to Seebach's work. $^{74}$

Vrancken and Mangeney ${ }^{77}$ found that lithiated allemamides generated from the propargyl amide 228 could undergo aldol reactions in the presence of $\mathrm{CuCN}$ to afford antihomopropargyl amino alcohols $\mathbf{2 4 1}$ with high yields and diastereoselectivities (Scheme 68). In most cases, the addition proceeds through the favored transition state anti $_{a} \mathbf{2 4 1}$.

West $^{78}$ found that when lithiated allenamides $\mathbf{2 4 3}$ reacted with unsaturated aldehydes, the resulting aldol product would undergo a 1,3-H shift to afford 2-amido-1,4-pentadiene-3-ones 246 (Scheme 69). While this work is being classified under aldol reaction, this beautiful tandem sequence of aldol addition-1,3-H-shift sequence constitutes a formal hydroacylation process of allenamides, and is indeed also related to Section 3.7. Tandem Cascades via Isomerizations. Subsequently, West carried out Lewis or Brønsted acid-promoted Nazarov cyclization employing these 2-amido-1,4-pentadiene-3-ones 246. Specifically, a reaction with 0.2 equiv of $\operatorname{In}(\mathrm{OTf})_{3}$ or 5.0 equiv of $\mathrm{TfOH}$ was found to be highly effective, leading to 2-amido-1-indanones $\mathbf{2 4 7}$ in good yields and high diastereoselectivity in most cases.

\subsection{Cyclizations}

We note here that some of the intramolecular hydroamination work featured in Section 3.2.3. Hydroamination (see Schemes 52, 53, and 55), and intramolecular hydroarylation reports showcased in Section 3.2.4. Hydroarylation (see Schemes 58 and 60) also involved cyclizations.

3.4.1. Non-Transition Metal-Mediated-Hacksell ${ }^{79}$ reported the first base-promoted cyclization involving allenamide intermediates in their effort to achieve $\mathrm{N}$-methylation of propargyl amides 248 (Scheme 70). With $\mathrm{NaH}$, methylated (when $\mathrm{R}=\mathrm{Me}$ ) propargyl amides isomerized to allenamides $\mathbf{2 4 9}$ in moderate yields. When $\mathrm{R}=\mathrm{H}$, allenamides $\mathbf{2 5 0}$ were believed to be the intermediate en route to the cyclized oxazoles $\mathbf{2 5 2}$.

Tanaka and Torii ${ }^{48 a}$ synthesized a series of antibiotics 3-norcephems 255 from a-acylated $\beta$ lactam derived allenamides 253 (Scheme 71). In their work, the key step involved a $\mathrm{CaCl}_{2}$ assisted 1,4-addition of nucleophiles to the central allenic carbon of $\mathbf{2 5 3}$ as shown in the complex 254. Although this could be considered also as an umpolung phenomenon, with the a-acyl group in $\mathbf{2 5 3}$, this is more in line with a classical 1,4-addition. An ensuing cyclization via a vinylogous enolate addition would furnish 255 .

Kant and Farina ${ }^{80}$ reported a related conjugate addition of organocuprates to allenamides 256 (Scheme 72). Subsequent cyclization through intermediates 257 would give cephams 258. 
Farina and $\mathrm{Kant}^{48 \mathrm{~b}}$ also uncovered that $\mathrm{LiBr}$ or $\mathrm{LiCl}$ could achieve the same purpose (Scheme 73). Mechanistically, this transformation should be similar to those in Schemes 71 and 72. With $\mathrm{X}=\mathrm{Ts}$ or $\mathrm{SAr}$ as a leaving group, $\mathrm{LiBr}$ (or $\mathrm{LiCl}$ ) would attack the more positively charged sulfur moiety to form a sulfenyl bromide $\mathbf{2 6 0}$ and lithium sulfinate Li-Ts (or LiSAr if $\mathrm{X}=\mathrm{SAr}$ ). The sulfenyl bromide motif in $\mathbf{2 6 0}$ could now electrophilically activate the terminal allenic double bond in an intramolecular manner leading to a bromonium ion intermediate, and an ensuing nucleophilic addition of the sulfide anion would lead to 261. Subsequently, a 1,4-addition of Li-Ts (or LiSAr) followed by elimination of $\mathrm{LiBr}$ would afford cephams $\mathbf{2 6 2}$.

Gericke $^{81}$ documented that cyclizations of 2-pyridone substituted allenamides $\mathbf{2 6 3}$ took place in different pathways depended on $\mathrm{R}$ groups and/or reaction conditions (Scheme 74). In chloroform at room temperature and when $\mathrm{R}=\mathrm{H}, \mathbf{2 6 3}$ was transformed to chromene 264 through a $6 \pi$-electron pericyclic ring-closure of the 1-oxatriene intermediate $\mathbf{2 6 5}$, which was generated through an initial $1,5-\mathrm{H}$ shift. At $60{ }^{\circ} \mathrm{C}$ when $\mathrm{R}=\mathrm{Ac}$, allenamide 263 would cyclize to first give the allylic anion intermediate 266. This allylic anion could then lead to benzofuran 267 or $\mathbf{2 6 9}$ through either abstracting a proton from DMSO when DMSO is the solvent (see $\boldsymbol{a}$ ); or when in toluene, trapping of the $\mathrm{Ac}^{+}$cation (see $\boldsymbol{b}$ ) followed by [3,3]sigmatropic rearrangement.

Noguchi ${ }^{82}$ demonstrated that iodine could promote the cyclization of allenamides $\mathbf{2 7 0}$ via a 6-endo-trig pathway (Scheme 75). Authors proposed that the iodonium intermediates 271 were formed selectively at the terminal olefin to deliver bicyclic guanidines $\mathbf{2 7 2}$.

Maddaluno ${ }^{83}$ reported the synthesis of 3-(2-ethoxy)vinyl indole 274 from allenamide $\mathbf{2 7 3}$ (Scheme 76). The $E$-isomer was obtained as the major product through an initial aryl lithium addition onto the central allenic carbon followed by elimination of an OEt group. The $E$ isomer 274 could serve as an excellent 1,3-diene to undergo thermal or high-pressure [4 +2] cycloaddition with ethyl acrylate 276 to give tetrahydro-carbazoles 275 .

Hsung ${ }^{84}$ found that depending on the reaction conditions, a series of urea derived $\gamma$ substituted chiral allenamides 277 could undergo cyclization to afford substituted dihydrofurans $\mathbf{2 7 9}$ when using TBAF or $\mathbf{2 8 1}$ when using PPTS (Scheme 77).

Vázquez ${ }^{85}$ illustrated that with TFA, allenamides $\mathbf{2 8 2}$ could be cyclized to give isoquinolines $\mathbf{2 8 4}$ via a Pictet-Spengler type cyclization onto $N$-acyl iminium ion $\mathbf{2 8 3}$ (Scheme 78).

Wang and $\mathrm{Lu}^{28 \mathrm{c}}$ demonstrated that haloindenyl sulfononamides $\mathbf{2 9 0}$ could be synthesized through a $\mathrm{BF}_{3}-\mathrm{OEt}_{2}$-catalyzed tandem sequence commencing from propargyl alcohols $\mathbf{2 8 5}$, sulfonamides, and NIS (Scheme 79). Although not isolated, the allenyl cations $\mathbf{2 8 8}$ was first formed via Meyer-Schuster rearrangement, and trapping of $\mathbf{2 8 8}$ with sulfonamides would lead to allenamides $\mathbf{2 8 7}$, which could then undergo subsequent iodonium promoted cyclization.

Wang and $\mathrm{Lu}^{28 \mathrm{a}}$ also reported that phosphoryl substituted allenamide 293, prepared from propargyl alcohol 291 through a $\mathrm{Yb}(\mathrm{III})$-catalyzed Meyer-Schuster rearrangement and 
trapping with phosphoramidate 292, could also undergo related cyclizations to give pyrrole 294 (Scheme 80). Intriguingly, iodine could promote the entire sequence en route to 294. The formation of this structurally interesting pyrrole 294 is proposed in Scheme 81 (see $\mathbf{2 9 3} \rightarrow \mathbf{2 9 6} \rightarrow \mathbf{2 9 7} \rightarrow \mathbf{2 9 4})$. In addition, authors found that when 295 reacted with $N$-tosyl hydroxylamine, allenamide $\mathbf{2 9 8}$ could be formed and further cyclize to give 2,5dihydroisoxazole $\mathbf{2 9 9}$ or 4-halo-2,5-dihydroisoxazole 300, respectively. ${ }^{28 \mathrm{~b}}$

Savic $^{86}$ discovered that upon treatment with $t$-BuOK, Boc protected propargyl aminopyridines $\mathbf{3 0 1}$ could be cyclized to imidazo[1,2-a]pyridine derivatives $\mathbf{3 0 3}$ (Scheme 82). Authors suggest that allenamides $\mathbf{3 0 2}$ are likely the key intermediate involved in these cyclization reactions.

Miranda ${ }^{87}$ reported a two-step operation to access 2,3-dihydropyrroles 306 involving a basepromoted cyclization of allenamide intermediates $\mathbf{3 0 5}$ (Scheme 83). A Ugi four-component reaction (Ugi 4-CR) ${ }^{88}$ was conducted with In(III) catalyst to afford propargyl amide 304. A subsequent base-promoted isomerization would generate allenamide intermediates $\mathbf{3 0 5}$, which subsequently underwent 5-endotrig cyclization to produce 2,3-dihydropyrroles $\mathbf{3 0 6}$.

3.4.2. Palladium Catalyzed Cyclizations-Grigg ${ }^{89}$ first reported a de novo palladiumcatalyzed intramolecular carbopalladation/cyclization-anion capture cascade process using allenamides 307 (Scheme 84). After oxidative addition of $\mathrm{Pd}(0)$ to the aryl iodide, a selective carbopalladation/cyclization onto the central allenic carbon would first generate the $\mathrm{Pd}$ - $\pi$-allyl complex $\mathbf{3 0 8}$. This $\pi$-allyl species could be captured regioselectively by amines in the presence of $\mathrm{K}_{2} \mathrm{CO}_{3}$ at the sterically less hindered $\gamma$-allenic position ( $\gamma$-attack), leading to allylic amines 309. Although $\alpha$-attack was confirmed by NMR, an equilibration appeared to take place under the reaction conditions to favor the more stable allylic amines. Intriguingly, the use of $\mathrm{Ag}_{2} \mathrm{CO}_{3}$ can alter this regioselectivity to favor in the a-attack as shown in vinyl aminal 309a'. Authors believed that with $\mathrm{Ag}_{2} \mathrm{CO}_{3}$, the reaction proceeds through the cationic $\pi$-ally complex 308', which would favor an a-attack and impede any ensuing equilibration.

In the related discovery of the Pd-catalyzed carbopalladation/cyclization-anion capture methodology, Grigg ${ }^{90}$ showcased a palladium-catalyzed hydrostannylationcarbopalladation/cyclization cascade to afford small (5-7) and large (11-17) nitrogenheterocycles, in which cyclization occurred at the a-allenic carbon (Scheme 85). A series of allenamides 310 could be subjected to highly regioselective palladium $[\operatorname{Pd}(0)$ or $\operatorname{Pd}(\mathrm{II})$ could be operative]-catalyzed hydrostannylations to afford allylstannanes $\mathbf{3 1 1}$ as a mixture of $E / Z$ isomers. Both $E / Z$ isomeric allylstannanes could undergo an ensuing sequence of oxidative addition, carbopalladation/cyclization, and elimination promoted by $\operatorname{Pd}(0)$. It is noteworthy that the elimination of $n-\mathrm{Bu}_{3} \mathrm{SnPdX}$ was faster than $\beta$-hydride (HPdX) elimination, thereby leading to the final products $\mathbf{3 1 4}$ in moderate to good yields.

Grigg $^{91}$ also reported an impressive poly-component cascade involving a wide range of regio- and stereoselective 5-, or 6-exo-dig cyclization (Scheme 86). Commencing from propargyl amides $\mathbf{3 1 5}$, a $\mathrm{Tl}_{2} \mathrm{CO}_{3}$ promoted isomerization would first lead to allenamides 316. Subsequent oxidative addition and carbopalladation/cyclization onto the central allenic 
carbon would afford the formation of an unstable enaminoindoles $\mathbf{3 1 8}$, which could be trapped through Diels-Alder cycloadditions with $N$-methylmaleimide (NMM) in refluxing $\mathrm{CH}_{3} \mathrm{CN}$ to yield endo-cycloadducts 319. Three examples from propargyl amides $\mathbf{3 2 0}$ to polycyclic products $\mathbf{3 2 1}$ were reported without isolation of the diene intermediate.

Grigg $^{92}$ also adopted organoboron reagents as anion transfer reagents in their palladiumcatalyzed cyclization-anion capturing cascade (Scheme 87). Again, after carbopalladation/ cyclization, the resulting palladium $\pi$-allyl complexes 323 could undergo transmetallation with boronic aids to give isoquinolones $\mathbf{3 2 4 a - c}$ after reductive elimination. Although minor isomer 325 was also found, the Suzuki-Miyaura type cross-coupling was overall highly regioselective and favored predominantly at the less hindered $\gamma$-allenic carbon regardless of the base used.

Organostannanes could also be utilized as anion capture reagents in a Stille-type crosscoupling to give isoquinolones 324d-e, although regiochemistry here was not as good ${ }^{93}$ (Scheme 88). Again intriguing here, $\mathrm{Ag}_{2} \mathrm{CO}_{3}$ appears to have no significant bearing on the regioselectivity (see Scheme 84). When $\mathrm{NaN}_{3}$ was used as the capture reagent, azides $\mathbf{3 2 6}^{94}$ could be attained (Scheme 89). Upon treatment with DMAD in benzene, an ensuing 1,3dipolar cycloaddition could take place to give triazole 328. A one-pot cascade using norbornadiene as the dipolarophile was also explored and triazole $\mathbf{3 2 9}$ was obtained after a retro Diels-Alder reaction of the initially generated triazoline cycloadduct $\mathbf{3 2 6}$.

Grigg ${ }^{95}$ subsequently rendered the anion capture part of their intramolecular cascade (Scheme 90). This process was initiated also through the same carbopalladation/cyclization and the formation of palladium $\pi$-allyl complexes $\mathbf{3 3 1}$ but followed by their interception, via an intramolecular nucleophilic addition, leading to polycyclic isoquinolones $\mathbf{3 3 2}$.

Grigg $^{96}$ reported another novel cascade process entailing a highly regio-and stereoselective $\mathrm{Pd} / \mathrm{In}$ bimetallic mediated cyclization-allylation reaction (Scheme 91). Transmetallation of the palladium $\pi$-allyl intermediate with indium followed by allylation of chiral sulfonamide $S$-344 afforded esters 336 with two contiguous chiral centers generated with complete stereochemical control. The major diastereomer could be rationalized through the more favored transition state $\mathbf{3 3 5}$ in which the coordination to In metal likely involves both the sulfoxide and carbonyl oxygen atoms.

Savic $^{97}$ showed their work on the palladium-catalyzed carbopalladation/cyclization-anion capture cascade but with the acetate anion as a capturing nucleophile (Scheme 92). The intramolecular version of this reaction proceeded quite well with allenamides $\mathbf{3 3 7}$ to give desired cyclized products $\mathbf{3 3 8}$. However, while the intermolecular version with allenamide 337c was also successful, a mixture of regioisomeric acetates 339 and $\mathbf{3 4 0}$ was obtained.

Fuwa and Sasaki ${ }^{98}$ unveiled a clever approach for the synthesis of 2,3-disubstituted indole derivatives based on the intramolecular carbopalladation/cyclization-anion capture strategy (Scheme 93). Allenamides 341 bearing a substituent at the a-position were found to undergo a facile carbopalladation/cyclization to generate the palladium $\pi$-allyl intermediate $\mathbf{3 4 2}$, 
which in turn could be cross-coupled with a wide range of orgnanoboron species to give a variety of 2,3-disubstituted indoles $\mathbf{3 4 3}$.

$\mathrm{Lai}^{57}$ also reported an example of the Pd-catalyzed carbopalladation/cyclization cascade while attempting to construct tetrasubstituted allenamides via Suzuki-Miyaura coupling (Scheme 94). When allenamide 344 reacted with (2-hydroxyphenyl)boronic acid 345, the cyclized amido-chromene product 347 was obtained instead of the a-aryl-substituted allenamide 346, although 346 likely had served as an intermediate.

Hiroya ${ }^{99}$ published a Pd-catalyzed annulation reaction of allenamide 349 with aryl iodides 348 (Scheme 95). In this work, the Pd- $\pi$-allyl species 350 readily underwent an intramolecular nucleophilic attack by an oxygen- or nitrogen-based nucleophile to give the annulated product 354. The product via a-attack in a 5- or 6-exo-trig manner was obtained exclusively regardless of the bulkiness of the allenic substituents. Authors proposed that the nitrogen stabilization could render the a-allenic carbon more electropositive than the $\gamma$ allenic carbon, thereby favoring the a-attack. In cases such as $\mathbf{3 5 4 a}$, it is also a matter of 5exo-trig a-attack versus 5-endo-trig $\gamma$-attacked.

Cheng ${ }^{100}$ described their Pd-catalyzed cyclization-capture cascade utilizing the bicyclic alkene 358 for the terminating process (Scheme 96). The palladium $\pi$-allyl complex 357 generated from allenamide $\mathbf{3 5 6}$ through the carbopalladation/cyclization sequence could be cross-coupled with oxa-norbornadiene $\mathbf{3 5 8}$, leading to 1,2-dihydroisoquinoline 362 in $78 \%$ yield. Authors proposed that the coordination of $\mathbf{3 5 8}$ to the palladium $\pi$-allyl complex $\mathbf{3 5 7}$ favored the exo face, and that an ensuing migratory insertion and $\beta$-oxy syn-elimination would lead to the palladium-oxo complex 361 before the $\mathrm{Zn}$-reduction.

Following their successful synthesis of substituted indoles, Fuwa and Sasaki ${ }^{101}$ evolved their strategy further to access indole-2,3-quinodimethanes 364 from allenamide 363 through the intermediacy of the cationic palladium $\pi$-allyl complex 364' (Scheme 97). Indole-2,3-quinodimethanes 364 could be trapped efficiently in situ through Diels-Alder cycloaddition with an external dienophile to afford tetrahydrocarbazoles $\mathbf{3 6 5}$ in excellent yields. In the absence of an external dienophile, homo-dimers 366/366' were isolated through a regioselective Diels-Alder cycloaddition in favor of $\mathbf{3 6 6}$.

Bäckvall ${ }^{102}$ recently published a novel Pd(II)-catalyzed oxidative carbocyclization methodology (Scheme 98). Under these conditions, allenamides 367 could cyclize to afford the corresponding dihydropyrrole derivatives 368. When maleimide was employed as a dienophile with the Co-salen type complex $\mathbf{3 7 0}$ as co-catalyst, a tandem oxidative cyclization/Diels-Alder reaction occurred to give the polycyclic endo-cycloadduct 369 .

3.4.3. Rhodium Catalyzed Cyclizations-Brummond ${ }^{103}$ first demonstrated a rhodium(I)-catalyzed allenic Alder-ene reaction employing alkynyl allenamides 371 (Scheme 99). A variety of cross-conjugated triene-containing heterocycles $\mathbf{3 7 2}$ were obtained in good to excellent yields. It was also demonstrated that when changing the atmosphere from argon to carbon monoxide, the reaction generated complex tricycles $\mathbf{3 7 3}$ in a Pauson-Khand manner with moderate diastereoselectivity. 
3.4.4. Gold Catalyzed Cyclizations-Hegedus ${ }^{104}$ published an efficient Au-catalyzed cyclization of chiral $\gamma$-substituted allenamides 374 (Scheme 100). An impressive series of highly functionalized cis-dihydrofurans $\mathbf{3 7 7}$ were synthesized as a single diastereomer. Authors also reported an alternative electrophilic activation method for cyclizing allenamides $\mathbf{3 7 4}$ that utilized NIS, leading to $\mathbf{3 7 5}$ with a handle for further elaboration at C-3 position of the furan ring.

Pérez-Castells ${ }^{105}$ reported an Au-catalyzed cyclization and a subsequent gold-promoted nucleophile trapping for the formation of benzazepines $\mathbf{3 8 3}$ (Scheme 101). In this reaction, authors proposed that the gold first coordinated with the allene rather than the alkyne group as shown in 379, although both coordination events are likely taking place and in rapid equilibrium. An ensuing nucleophilic attack accounted for the formation of enamides $\mathbf{3 8 0}$, and at subsequent gold promoted cyclization onto the alkyne would occur (see $\mathbf{3 8 1} \rightarrow \mathbf{3 8 2} \rightarrow \mathbf{3 8 3}$ ). It was also found that if the $N$-substituent $\mathrm{X}$ were less electronwithdrawing than sulfonyl groups, this cyclization did not take place.

Hsung ${ }^{106}$ published an Au-catalyzed imino-Nazarov cyclization of a-aryl substituted allenamides 384 (Scheme 102). This regioselective cascade provided an efficient synthetic method in constructing aromatic ring-fused cyclopentenamides 387. Authors suggested that the electronic preference accounted for the observed regioselectivity.

3.4.5. Radical Cyclizations-Hsung ${ }^{107}$ reported the first radical cyclization of allenamides (Scheme 103). This cyclization reaction was highly regioselective for the central allenic carbon in $\mathbf{3 8 8}$, leading to isoquinolines and isoindoles $\mathbf{3 8 9}$ in good to excellent yields. Authors suggested that the electronic nature of the allenamide nitrogen atom has no impact on the regioselectivity.

In addition, when chiral allenamides $\mathbf{3 9 0}$ with the aryl iodide group tethered through the acarbon of the allenamide were employed, the radical cyclization afforded exclusively the central-cyclized indene products 391 (Scheme 104). Authors also described a tandem radical cyclization using allenamide 392 to give tricycle 394. An initial exo-cyclization onto the a-allenic carbon of $\mathbf{3 9 3}$ appeared to be prerequisite for completing the tandem process.

3.4.6. Garratt-Braverman Cyclization-Garratt-Braverman cyclization, 108 a biradical generating process, represents a powerful tool for new CC bond formation. ${ }^{108 \mathrm{c}}$ Recently, Basak ${ }^{109}$ demonstrated successful construction of indolyl carbazole 399 through GarrattBraverman cyclization of bis-allenamide 396 (Scheme 105). When refluxed in toluene in the presence of $t$ - $\mathrm{BuOK}$, amide 395 underwent isomerization to bis-allenamide 396, and the subsequent intramolecular cyclization generated the biradical pyrrole intermediate 397 . The final product indolyl carbazole 399 was produced through the self-quenching/cyclization followed by aromatization.

3.4.7. Electrocyclization(EC)—Besides Garratt-Braverman cyclization, allenamides $\mathbf{4 0 1}$ could also be utilized to construct 6-membered aromatics through electrocyclization (Scheme 106). Zhou ${ }^{110}$ synthesized a series of polyfunctional benzenes $\mathbf{4 0 3}$ from dienepropargyl amides $\mathbf{4 0 0}$. They proposed that allenamides $\mathbf{4 0 1}$ were the precursor subject to the 
$6 \pi$ EC reaction to afford cyclized intermediates $\mathbf{4 0 2}$. In the presence of DBU, 402 isomerized to desired products $\mathbf{4 0 3}$ via aromatization.

\subsection{Ring-Closing Metathesis}

Hiemstra and Rutjes ${ }^{111}$ attempted to date the only ring-closing metathesis reaction involving allenamides (Scheme 107). However, when using allenamide 404, dienamide 405 was isolated as a result of the Ru-catalyzed isomerization (or 1,3-H shift), and the desired RCM product 406 was not observed.

\subsection{Cycloadditions}

3.6.1. [2 + 1] Cycloadditions-Hsung ${ }^{112}$ reported the first detailed studies on epoxidations of chiral allenamides including ${ }^{1} \mathrm{H}$ NMR studies of these reactions (Scheme 108). When Oxone ${ }^{\mathrm{TM}}$ was used, isolation of cyclic ether $\mathbf{4 1 0}$ suggested that a more acidic medium during the oxidation can promote rapid ring-opening of allene oxide or epoxyallene 408 to provide the a, $\beta$-unsaturated $N$-acyl iminium intermediate 409. A subsequent intramolecular 1,4-addition would generate ether 410. The DMDO epoxidation of $\mathbf{4 0 7}$ in the presence of PPTS led to the formation of a mixture of pyrans 411a and 411b, which represent a 1,2-addition process to the $\mathrm{N}$-acyl iminium intermediate related to $\mathbf{4 0 9}$ derived 408. Isolation of the major pyran $\mathbf{4 1 1 b}$ also implies double epoxidation of $\mathbf{4 0 7}$ or possible presence of a 2-amido-1,4-dioxasprio[2.2]pentane intermediate [not shown]. Treatment of allenamide $\mathbf{4 0 7}$ with buffered $m$-CPBA led to highly stereoselective formation of a-keto$\mathrm{N}, \mathrm{O}$-acetal 412, thereby suggesting a very rapid in situ trapping of $\mathbf{4 0 8}$ by the $\mathrm{m}$ chlorobenzoate anion.

Hsung ${ }^{113}$ published a detailed account of Simmons-Smith cyclopropanation of allenamides to generate amido-spiro[2,2]pentanes (Scheme 109). For a-unsubstituted allenamides 413, only biscyclopropanation products $\mathbf{4 1 4}$ were observed, while a-substituted allenamides resulted in mixtures of mono- and bis-cyclopropanation products 415 and 414.

Diastereoselectivity was modest but a conformational analysis was proposed in Scheme 110 to account for the lack of selectivity. The preference for the two conformers 416 and $\mathbf{4 1 7}$ is small, and because the first cyclopropanation to $\mathbf{4 1 6}$ and $\mathbf{4 1 7}$ took place very rapidly, there was very little facial selectivity, as both $\mathbf{4 1 6}$ and $\mathbf{4 1 7}$ could participate cyclopropanation via their respective open face. However, the selectivity increases modestly when $R^{3} \neq H$ because $\mathbf{4 1 6}$ becomes more favored as the conformer $\mathbf{4 1 7}$ suffers from enhanced $\mathrm{A}^{1,3}$ strain.

3.6.2. [2 + 2] Cycloadditions-Studies of [2 + 2] cycloadditions were carried out by several research groups, among them Tamaru ${ }^{14 a}$ was the earliest in reporting their thermal $[2+2]$ cycloaddition of allenamides. Various allenamides 422 underwent [2+2] cycloaddition reactions chemoselectively at the allenic $\beta, \gamma$-position with alkenes and alkynes to furnish cyclobutanes $\mathbf{4 2 3}$ and cyclobutenes $\mathbf{4 2 4}$ regio- and stereoselectively ${ }^{114 \mathrm{~b}}$ (Scheme 111). This methodology is general for alkenes bearing not only electronwithdrawing and conjugating groups but also electron-donating groups with complete retention of the alkene double bond geometries. However, the reaction is limited to terminal alkenes and alkynes, as internal alkynes, alkenes, and 1,3-dienes were unreactive. 
In detailed study, Tamaru ${ }^{115}$ documented an interesting dichotomy between inverse demand hetero-[4+2] and [2+2] cycloadditions of allenamides (Scheme 112). Depending upon the alkene substitution pattern, allenamides can react with siloxydienes, enol ethers, and allylsilanes to either undergo [2+2] cycloadditions to exclusively provide cyclobutane derivatives, or a hetero-[4+2] cycloaddition pathway with a vinyl $N$-acyl imine intermediate resulting from an initial 1,3-Ts shift. While details of this excellent and thorough investigation will not be digested here and can be found in the original paper, see Section 3.6.5 for discussions on the 1,3-Ts-shift-inverse demand hetero-[4 + 2] cycloaddition cascade.

Nair ${ }^{116}$ published a unique [2+2] cycloaddition of allenamides 434 with [60]fullerene 435 to afford novel cyclobutane annulated fullerene derivatives $\mathbf{4 3 6}$ (Scheme 113). The reaction took place selectively on the internal double bond of allenamides, which had not been observed previously.

Chen ${ }^{117}$ reported the first publication of Au-catalyzed [2 + 2] cycloadditions of allenamides (Scheme 114). Their methodology provided densely functionalized cyclobutane adducts 439 using a wide range of allenamides 437 with electron-rich olefins 438 . The cycloaddition was completely regio- and stereoselective, although $\alpha$ - or $\gamma$-substituted allenamides did not give desired products possibly due to the steric hindrance. The author also reported dimerization of starting allenamides $\mathbf{4 3 7}$ under the Au-catalysis in the absence of alkenes, leading to a series of dimerization products $\mathbf{4 4 0}$ (Scheme 115).

Mascareñas ${ }^{118}$ reported a highly regioselective Au-catalyzed intermolecular [2 + 2] cycloaddition of allenamide $\mathbf{4 4 1}$ with various alkenes $\mathbf{4 4 2}$ for the synthesis of cyclobutanes 443 (Scheme 116). Most critically, these authors found that when using enamides as reacting partners, both $(E)$ and $(Z)$ isomers of enamides $442 \mathbf{e}$ and $\mathbf{4 4 2 f}$ generated single transstereoisomer as shown in $\mathbf{4 4 3 e}$ and $\mathbf{4 4 3 f}$, respectively, thereby suggesting a stepwise cationic pathway. Intermolecular nucleophilic interception of the Au-allyl cation species 444 by the alkene would form a second cationic intermediate $\mathbf{4 4 5}$. The formation of the more stabilized benzylic or $\mathrm{N}$-acyl iminium cation (when using cyclic or acyclic enamides) should lead to the observed regioselectivity, while rotation around the $\sigma_{\mathrm{C}-\mathrm{C}}$ bond would result in the loss of original alkene stereochemical information. A final allenamide nitrogen atomassisted ring-closing process followed by elimination and regeneration of the Au complex would furnish [2+2] adduct $\mathbf{4 4 3}$.

González ${ }^{119}$ independently published their Au-catalyzed [2+2] cycloaddition of $N$-tosyl allenamides 446 with enol ethers 447 (Scheme 117) at the same time. Although the same gold complex was used as in Mascareñas's report, catalyst loading was much lower, and more importantly, $\gamma$-substituted allenamides worked very well in this system to generate the cycloadduct such as $\mathbf{4 4 8 c}$.

3.6.3. $[2+2+1]$ Cycloadditions-Hsung ${ }^{58}$ first published a regioselective adeprotonation and functionalization of electron-deficient allenamides 449 , and application of the resulting a-substituted allenamides in an intramolecular Pauson-Khand-type cycloaddition (Scheme 118). The functionalized allenamides $\mathbf{4 5 0}$ were treated with 
$\mathrm{Mo}(\mathrm{CO})_{6}$ to provide the desired [2+2+1] cycloaddition products 451 regioselectively in favor of the terminal olefin. As the first examples of Pauson-Khand-type reactions involving nitrogensubstituted allenes, these authors accounted the regioselectivity as a result of the Mo metal complexing to the less sterically congested terminal olefin of the allene.

Pérex-Castells ${ }^{120}$ reported the first intermolecular Pauson-Khand reaction of allenamides 452 promoted with $\mathrm{Co}(\mathrm{CO})_{8}$ (Scheme 119). These reactions were both regio- and stereoselective with several alkynes 453 to give functionalized cyclopentenones 454 bearing an exo-cyclic $E$-enamide. Subsequently, Pérez-Castells ${ }^{121}$ unveiled a $\mathrm{Mo}(\mathrm{MeCN})_{3}(\mathrm{CO})_{3}$ intramolecular Pauson-Khand type reaction of allenamide 455, leading to tricycle 456 in $43 \%$ yield, although the original Co-conditions were not effective (Scheme 120). In it noteworthy that $\mathrm{Oh}^{122}$ had earlier also demonstrated a molybdenumcatalyzed $[2+2+1]$ cycloaddition of allenamide $\mathbf{4 5 7}$ to produce compound $\mathbf{4 5 8}$ (Scheme 121).

3.6.4. [3 + 2] Cycloadditions-Broggini and Zecchi ${ }^{123}$ documented the first $[3+2]$ cycloaddition in which a series of allenamides 459 were treated with benzonitrile oxide 460 under thermal conditions (Scheme 122). The reaction occurred predominantly at the internal double bond of allenamides to give dihydroisoxazoles $\mathbf{4 6 2}$ with an exo-cyclic olefin as the major product, which reacted readily with excess amount of benzonitrile oxide $\mathbf{4 6 0}$ to provide bis-spiro-oxazoles 463 . In addition, unlike 462, the minor cycloadduct 461 was inert toward a second cycloaddition due to the sterics.

Tamaru $^{114 \mathrm{~b}}$ also reported hetero-[3 +2$]$ cycloadditions of allenamides 464 with nitrile oxide 465 (Scheme 123). The reaction also took place on the internal double bond to afford diazadioxaspirocycles 466.

Barluenga ${ }^{124}$ published the first Rh-catalyzed carbo-[3 + 2] cycloaddition of allenamides 467 with chromium alkenyl(methoxy)carbine complexes 468 (Scheme 124). Most cyclization reactions took place with complete chemo-, regio-, and diastereoselectivities, leading to a broad range of functionalized amidocyclopentenes $\mathbf{4 6 9}$ in good to excellent yields. A tentative reaction pathway for the cycloaddition involved the Fischer-type rhodium(I)-carbene complexes $\mathbf{4 7 0}$ generated via a chromium-rhodium exchange. $\mathrm{CO}$ appears to be critical in this cycloaddition, as it not only improved the efficiency of the catalytic reaction by favoring the transmetallation step, but also allowed almost quantitatively recovery of $\mathrm{Cr}(\mathrm{CO})_{6}$.

Piperno and Romeo ${ }^{125}$ reported an example of thermal [3 + 2] cycloaddition of pyrimidinedione containing allenamide $\mathbf{4 7 1}$ with nitrone $\mathbf{4 7 2}$ under conditions using microwave irradiation, leading to a mixture of iso-oxazolidines 473, 474 and 475 (Scheme 125). The cycloadducts 473 and 474 represent the two possible regiochemical addition of nitrone onto the terminal allenic double bond with a ratio of 7:1 in favor of the former, while the stereochemistry of iso-oxazolidine $\mathbf{4 7 5}$ was assigned by NOE as trans.

Piperno, Romeo, and Rescifina ${ }^{126}$ later published another microwave assisted [3 + 2] cycloaddition of allenamides 476 with nitrones 477 (Scheme 126). In this work, both cycloadducts 478 and 479 were observed, representing cycloadditions onto the internal and 
terminal allenic double bonds, respectively. The cycloadduct 479 was believed to be a result of thermal equilibration from $\mathbf{4 7 8}$ through intermediates $\mathbf{4 8 0}$ and $\mathbf{4 8 1}$.

Wang and $\mathrm{Lu}^{127}$ reported an efficient strategy for the synthesis of functionalized pyrazoles 486 from propargyl alcohol and $N$-sulfonyl-hydrazone (Scheme 127). $N$-Sulfonyl allenamide 484 was postulated as the key intermediate for this impressive tandem cascade as mapped in Scheme 127, featuring a pseudo-pericyclic $(2 n+4 \pi)$ ring-closure of $\mathbf{4 8 4}$ and representing ultimately a formal [3 +2] cycloaddition process. Various propargyl alcohols $\mathbf{4 8 2}$ and hydrazones 483 were applicable to give products $\mathbf{4 8 6}$, although lower yields were obtained for hydrazones derived from aliphatic aldehydes.

3.6.5. [4 + 2] Cycloadditions-Tamaru ${ }^{50}$ examined the first inverse electron-demand hetero-[4 + 2] cycloaddition reaction of allenamides $\mathbf{4 8 9}$ with MVK under thermal conditions (Scheme 128). The cycloaddition took place selectively at the internal double bond, leading to the desired spiro $\mathrm{N}, \mathrm{O}$-acetal products $\mathbf{4 9 0}$ in excellent yields.

These authors also conducted a detailed study of this [4 +2] cycloaddition using allenamides 491 with a series of heterodienes (Scheme 129). ${ }^{114 \mathrm{~b}}$ While a competing [2+2] cycloaddition product was also detected (vide supra), ratios of the [4+2] cycloadducts versus the corresponding $[2+2]$ cycloadducts varied with different heterodienes. The reaction with MVK afforded the $[4+2]$ product 492a in $80 \%$ yield, while the reaction with 2 -methylacrolein predominantly gave the $[2+2]$ addition product $493 \mathrm{~d}$. The product distribution could be qualitatively rationalized by the charge delocalization caused by different substitution patterns (Scheme 130), that is, the methyl group of MVK increases the electron density on $\mathrm{O}$ atom and promotes the $[4+2]$ reaction while the methyl group of $\mathrm{a}$ methylacrolein decreases the positive charge on the terminal $\mathrm{CH}_{2}$ and retards the [4+2] reaction. Relative activation energies were calculated and changed just as expected (-3.0, 0.0, 9.3 12.7 for 492a-d respectively with acrolein as the standard). Detailed investigation can be found in the origin paper.

Hsung ${ }^{41 \mathrm{~b}}$ also disclosed an inverse electron-demand hetero-[4 + 2] cycloaddition reaction of allenamides 495 with acrolein or MVK (Scheme 131). The reaction of allenamides 495 containing a lactam moiety could proceed under both thermal and Lewis acid conditions with the five-membered lactam allenamide $(n=1)$ giving the best results. Further studies revealed that allenamides $\mathbf{4 9 7}$ containing an oxazolidinone or imidazolidinone moiety proved to be more reactive.

Hsung ${ }^{128}$ further reported the first stereoselective version of this hetero-[4 + 2] cycloaddition reaction with chiral allenamides 499 (Scheme 132). A series of heterodienes as well as chiral allenamides were examined, affording pyranyl heterocycles $\mathbf{5 0 0}$ in good yields with selectivity being as high as $\geq 96: 4$.

To illustrate synthetic utilities of these pyranyl cycloadducts, Hsung ${ }^{129}$ developed the first Lewis acid catalyzed stereoselective removal of the anomeric chiral urea group concomitant with allylation to give pyrans $\mathbf{5 0 2}$ (Scheme 133). Based on this methodology, an array of highly functionalized and structurally interesting tetrahydropyrans was assembled in 
stereoselective manner (Scheme 134). These studies eventually led to the formal synthesis of natural product (+)-zincophorin (vide infra).

Hsung ${ }^{130}$ also described the inverse electron-demand $a z a-[4+2]$ cycloaddition reaction of chiral allenamides 509 employing phenylsulfonyl protected 1-azadiene 508 (Scheme 135). Despite the moderate yield and selectivity, this $a z a-[4+2]$ reaction demonstrated the synthetic utility of chiral alleneamides for the synthesis of $a z a$-glycoside related heterocycles.

Van Vranken ${ }^{32}$ was the first to demonstrate that an allenamide could actually participate in a normal electron-demand [4+2] cycloaddition reaction with the external double bond of the allene motif serving as the corresponding dienophile. These authors reported an example of such reaction with allenamide 511, which afforded cycloadduct 512 containing an enamide motif in 57\% yield (Scheme 136). It is noteworthy that Mapp ${ }^{27}$ also reported a similar reaction with $N$-phosporamidate substituted allenamide, which was synthesized using the method they had developed (See cycloadduct 512a and Scheme 17)

Hsung ${ }^{131}$ later showed that a stereoselective intramolecular normal electron demand [4 + 2] cycloaddition of allenamides $\mathbf{5 1 3}$ tethered to a diene motif could be achieved in good to excellent yields (Scheme 137). While Brønsted acids or transition metals including noble metals $\mathrm{AuCl}, \mathrm{AgBF}_{4}$ and $\mathrm{AgSbF}_{6}$ could also catalyze this cycloaddition, and that this work predates elegant and high profiled efforts by Mascareñas and co-workers (See below), they were not necessary as thermal conditions was sufficient to give comparable results. Based on these efforts, the authors developed a tandem isomerization-[4+2] cycloaddition sequence using propargyl amides $\mathbf{5 1 5}$, leading to a rapid assembly of structural complexity as demonstrated in $\mathbf{5 1 4}$ (Scheme 138).

López and Mascareñas ${ }^{132}$ unveiled an intermolecular [4 + 2] reaction of allenamides 516 with a series of acyclic conjugated dienes to afford $\mathbf{5 1 7}$ in moderate to excellent yields and high $Z$ selectivities (referring to the enamide double bonds) (Scheme 139). A preliminary reactivity screening revealed that similar reactions with either isolated allenes or allenol ethers instead of allenamides led to only complex mixtures, thereby further confirming the superiority of allenamides in these reactions. $\mathrm{AuCl}$ was proved to be a suitable catalyst for this cycloaddition reaction with cationic $\mathrm{IPrAuCl} / \mathrm{AgSbF}_{6}$ providing better results in some cases.

Mascareñas and co-workers ${ }^{133}$ then reported an impressive enantioselective version of this $[4+2]$ reaction (Scheme 140). High enantioselectivities (usually >90\% ee) were obtained using chiral $\mathrm{Au}(\mathrm{I})$ complex $\mathbf{5 2 0}$ containing axially chiral triazoloisoquinolin-3-ylidene ligands. This method represented the first example of a highly enantioselective intermolecular $[4+2]$ cycloaddition of allenamides.

Huang ${ }^{134}$ reported a facile synthesis of highly substituted tetrahydro- $1 H$-isoindolones from conjugated vinylic alkynes, imines and $\alpha, \beta$-unsaturated enoic acid chlorides (Scheme 141). This reaction sequence proceeded through a CuI-catalyzed addition of alkyne $\mathbf{5 2 2}$ to imine $\mathbf{5 2 3}$ followed by amidation to give enyne $\mathbf{5 2 5}$. Enyne $\mathbf{5 2 5}$ could then undergo a cascade of 
DBU induced propargyl amide-allenamide isomerization and intramolecular [4 + 2] cycloaddition, leading to the desired product 527a in good yield. Although sufficiently stable, isolation of the pure $\mathbf{5 2 5}$ was not necessary and the sequence worked very well in one pot.

Wu and Huang ${ }^{135}$ disclosed a convenient one-pot synthesis of substituted isoindolines (Scheme 142). DBN-induced isomerization of bis-propargyl amides 531, which were generated via Pd-catalyzed Sonogashira-type cross-coupling of $\beta$-iodoenones $\mathbf{5 2 8}$ (or electronic deficient iodobenzenes, see 530df) with bis-propargyl amides 529, would afford allenamide intermediates $\mathbf{5 3 2}$ that could further undergo an intramolecular [4 + 2] cycloaddition/aromatization to deliver $\mathbf{5 3 0}$ in moderate to good yields.

Tamaru ${ }^{136,115}$ uncovered an unusual thermal 1,3-Ts-shift-hetero-[4 + 2] cycloaddition cascade employing allenamides $\mathbf{5 3 3}$ (Scheme 143). In the presence of a large excess of enol ethers 534, the Ts group underwent $\mathrm{N}$-to-C 1,3-migration concomitant with an ensuing hetero-[4+2] cycloaddition. The reaction was highly stereoselective with complete retention of configurations in the starting alkenes in which Z-enol ethers gave cis-products, while $E$-enol ethers afforded trans-products. However, the recovered enol ethers revealed that disubstituted acyclic $Z$-enol ethers had isomerized to give a $Z / E$ mixture under the reaction conditions, while no isomerization took place without allenamides.

Consequently, authors suggested a unique enol ether-promoted 1,3-Ts-migration mechanism through the intermediacy of zwitter ion $\mathbf{5 3 7}$ to deliver 1-azadiene $s$-trans-538 with the loss of geometrical integrity of enol ether as shown in path $\mathbf{A}$ and/or pathway B-to-C (Scheme 144). The ultimate cycloaddition of reactive $s$-cis-538 with more reactive $Z$-enol ethers would afford the desired adducts $\mathbf{5 4 0}$ in a stereospecific manner. Although a direct cyclization pathway from $E-\mathbf{5 3 9}$ after equilibrating from Z-539 (Path B-to-D) is a distinct possibility, the fact that cycloadduct $\mathbf{5 4 0}$ was isolated exclusively as cis ruled out this possibility, this is less likely because such cyclization would lose the original stereochemical information of the enol ether.

Tamaru ${ }^{137,115}$ further studied the reaction of allenamide $\mathbf{5 4 1}$ with allylsilanes $\mathbf{5 4 2}$ to achieve a better understanding of this unique 1,3-sulfonyl rearrangement (Scheme 145). Under thermal conditions, the desired $[4+2]$ adducts 543a-c were obtained with allylsilanes 542a-c. A small amount of $\mathbf{5 4 4}$ was also isolated as a side product, but its mechanism was not clear. Authors again suggested that the nucleophilicity of silanes was not the key factor, and instead they proposed that the Lewis acidity of silicon might be critical for promoting the sulfonyl shift.

3.6.6. [3 + 3] Formal Cycloadditions-Kuroda ${ }^{138}$ unveiled the only example of [3+3] formal cycloadditions or annulations ${ }^{139}$ of allenamides 545 with phenols 546 (Scheme 146). These annulations could be carried out under mild conditions in the presence of a catalytic amount of $\mathrm{Tf}_{2} \mathrm{NH}$, leading to a series of highly functionalized chromanes 547. This methodology also represents a formal hydroarylation at the terminal carbon of the allenic double bond without any metal catalyst. 
3.6.7. [4 + 3] Cycloadditions-In 2001, Hsung ${ }^{140}$ uncovered a novel cascade consisting of epoxidation of chiral allenamides $\mathbf{5 4 8}$ with DMDO followed by [4+3] cycloadditions ${ }^{141}$ of various dienes, leading to oxabicyclo[3.2.1] octanes 549 (Scheme 147). The reaction was initially believed to proceed through the Z-isomer of nitrogen-stabilized oxyallyl cations, which were generated through ring-opening of the allenoxide intermediate (see Scheme 108). With the Z-oxyallyl cations being operative and sterics serving as the key and the only stereochemical controlling element, approaching of the diene from the less congested top face [called endo-I here for consistency] would lead to the major endo-I cycloadduct as assigned for 549a. Improvement of the overall stereoselectivity when using $\mathrm{ZnCl}_{2}$ further deepens the faith in such a claim because the zinc cation can lock up the oxyallyl cation in a bidentate manner to further enhance the facial differentiation.

Hsung ${ }^{142}$ later found a reversal of diastereoselectivity in the [4 +3] cycloaddition of allenamides with 2-substituted furan. While DMDO oxidation of allenamide $\mathbf{5 4 8}$ in the presence of 2-methyl furan and $\mathrm{ZnCl}_{2}$ afforded 551a as the major product, the corresponding cycloaddition reaction with methyl 2-furoate afforded the endo-II type adduct 552b more favorably (Scheme 148). These results collectively aroused suspicious of the original stereochemical understanding of this cycloaddition, and more critically, initiated a long-term collaborative effort to understand the regiochemical outcome of this cycloaddition regiochemically, which has been devoid of within the literature.

Consequently, Krenske, Houk, and Hsung ${ }^{143}$ conducted a detailed mechanistic study of this nitrogenstabilized oxyallyl cation [4 +3 ] cycloadditions to provide a rationale. DFT calculations revealed that the $E$-oxyallyl cations were actually the preferred species regardless of the presence of $\mathrm{ZnCl}_{2}$, and there was no bidentate coordination (Scheme 149). Furthermore, when phenyl-substituted Evans auxiliary was employed as the chiral auxiliary as shown in allenamide $\mathbf{5 4 8}$, the approach of dienes preferred the sterically more hindered face of the oxyallyl cation! This contrasteric approach was attributed to a stabilizing $\mathrm{CH}-\pi$ interaction between the $\mathrm{C} 3-\mathrm{H}$ on furan and the phenyl substituent as in $\mathbf{5 5 3}$ (Scheme 150).

On the other hand, when no $\mathrm{CH}-\pi$ interaction could be achieved, as with the Bn-substituted Evans auxiliary, reaction did indeed proceed from the sterically less hindered face of the $E$ oxyallyl cation to provide the endo-II cycloadduct $\mathbf{5 5 4}$ as the major product. Steric preference and $\mathrm{CH}-\pi$ interaction could also operate in sync to give $\mathbf{5 5 5}$ (note the $S$ stereochemistry) in excellent diastereoselectivity. These new mechanistic insights provided corrections to the stereochemical assignment of 549d and 549e (see Scheme 147), which should in fact be as shown in $\mathbf{5 5 4}$ and $\mathbf{5 5 5}$, respectively.

Based on the new theoretical evidence, Krenske, Houk, and Hsung ${ }^{144}$ subsequently disclosed a systematic study of the [4+3] cycloaddition reaction of achiral allenamide $\mathbf{5 5 6}$ with unsymmetrically substituted furans and established the first cohesive model for the regiochemistry of $[4+3]$ cycloadditions based on both theory and experiments (Scheme 151). For reactions with 2-substituted or 2,3-disubstituted furans, syn selectivity was favored, while anti was favored for cycloadditions with 3-substituted furans. DFT Calculations predicted the correct major products and brought forth the first cohesive mechanistic model based on the theoretic premise that (a) these nitrogen-stabilized oxyallyl 
cations are actually ambiphlic with enolate like-character in their HOMO; and (b) while asynchronously concerted, $\omega$-bond formation occurs first (Scheme 152). Consequently, with electron-withdrawing ester groups, the regiochemical preference was consistent with electronic effects, mimicking a conjugate addition, while the observed regioselectivities for methylfurans likely a result of the preference for least hindered $\omega$-bond formation.

Krenske, Houk, and Hsung ${ }^{145}$ further studied both regio- and stereoselectivity of [4 + 3] cycloadditions of 2 or 3-monosubstituted furans with chiral allenamides 548 (Schemes 153). For brevity and clarity, only a few examples of C-3-substituted cases are shown here, while details can be referred back to the original publication. Overall, the regiochemical model for achiral allenamides is consistent with these experimentally observed regioselectivities, and the new stereochemical model could be again adopted for the observed endo-I/II selectivities.

Krenske, Houk, and Hsung ${ }^{146}$ recently also disclosed their investigations of regio- and stereoselectivity issues of [4+3] cycloadditions of chiral allenamide $\mathbf{5 4 8}$ with a series unsymmetrically disubstituted furans (Scheme 154). The reaction was found to give synendo-II products 560 predominantly. DFT calculations were again performed to rationalize the experimental outcomes. Interestingly, in the calculated TS-561, the original proposed $\mathrm{CH}-\pi$ interaction was not found.

Song and Hsung ${ }^{147}$ demonstrated that these nitrogen-stabilized oxyallyl cations are also suitable for [4+3] cycloadditions with protected pyrroles 564 to construct tropanone systems (Scheme 155). This cycloaddition reaction showed similar stereoselectivities as those with furans.

Hsung ${ }^{148}$ unveiled an enantioselective [4 + 3] cycloaddition reaction ${ }^{149}$ using Lewis acid catalysts (Scheme 156). Reactions of allenamides 556 with DMDO and various dienes in the presence of catalytic $\mathrm{CuOTf}_{2}$ and $C_{2}$-symmetric bisoxazoline $\mathbf{5 6 5}$ afforded cycloadducts 566 in good yields and up to $99 \%$ ee. This asymmetric reaction with unsymmetrical furans also provided regioselectivities consistent with what have been discussed above.

Hsung ${ }^{150}$ also reported a stereoselective intramolecular [4 +3] cycloaddition reaction of allenamides 567 or 570 with $N$-tethered dienes through the intermediacy of the $E$-oxyallyl cation 569 (Schemes 157 and 158). A series of $N$-heterocyclic products 568 and $\mathbf{5 7 1}$, including tethers to form 7- and 8-membered rings (571g and 568d), was obtained in good yields and exo selectivity was actually observed. The tolerance of longer tethering length reaffirms the advantage of nitrogen-stabilized oxyallyl cations because of the conformationally rigid trivalent nature of the nitrogen atom and its aptitude to overcome greater entropy for intramolecular cycloadditions.

Hsung ${ }^{151}$ further extended this diastereoselective intramolecular [4 + 3] cycloaddition to disubstituted chiral allenamides with the diene motif being tethered at either a- or $\gamma$-allenic carbon (Scheme 159). High endo-selectivity was observed for these reactions, and interestingly, for $\gamma$-tethered allenamides $\mathbf{5 7 5}$ and 576, the axial chirality of allenamides did not have an impact on the overall stereoselectivity of the cycloaddition. 


\subsection{Tandem Cascades via Isomerizations}

3.7.1. a-Isomerization-Hsung ${ }^{152 a}$ reported a series of studies on regio- and stereoselective isomerizations of allenamides with first of which leading to the preparation of de novo 2-amido-dienes and a tandem isomerization-6p-electron electrocyclic ringclosure (Scheme 160). It was found that under either thermal conditions (condition A) or Brønsted acidic conditions (condition B), allenamides $\mathbf{5 8 0}$ underwent effective isomerization, or 1,3-H shift, to give de novo 2-amido-dienes 581. This 1,3-H shift was found to be highly regio- and stereoselective, as products $\mathbf{5 8 1}$ were obtained with >20:1 E/Z ratios. It is noteworthy that related $1,3-\mathrm{H}$ shift has been documented by others ${ }^{78,152 \mathrm{~b}}$ (also see Scheme 69). Recently, Das ${ }^{152 \mathrm{c}}$ reported a computational study on such 1,3-H shift. Details of their study will not be discussed here.

The excellent $E$-selectivity attained provided a platform for a pericyclic transformation, as allenamide $\mathbf{5 8 2}$ underwent isomerization to give 3-amido-triene $\mathbf{5 8 3}$ in 89\% yield, and subsequently, a thermal $6 \pi$-electron electrocyclic ring-closure of $\mathbf{5 8 3}$ gave cyclic diene $\mathbf{5 8 4}$. Alternatively, cyclic diene $\mathbf{5 8 4}$ could also be obtained directly from allenamide $\mathbf{5 8 2}$ under thermal condition in a tandem sequence, albeit with lower overall yield.

Hsung ${ }^{153}$ subsequently expanded the substrate scope of this $1,3-\mathrm{H}$ shift for the preparation of 3-amidotrienes. Under acidic conditions, allenamides $\mathbf{5 8 5}$ can be efficiently transformed into 3-amido-trienes $\mathbf{5 8 6}$ in good to excellent yields (Scheme 161). Allenamides such as $\mathbf{5 8 7}$ with both $\mathrm{a}$ - and $\gamma$-substitutions were also examined. The 1,3-H shift in this case was found to be completely regioselective and took place exclusively from the a-position, affording highly substituted (E)-3-amido-trienes $\mathbf{5 8 8 a}-\mathbf{b}$.

Hsung ${ }^{154}$ also found that heating allenamide $\mathbf{5 8 9}$ led to two ring-closure products: the desired cyclic 2-amido diene $\mathbf{5 9 1}$ and the unexpected 1-amido diene $\mathbf{5 9 2}$ in 1:4.5 ratio (Scheme 162). The formation of $\mathbf{5 9 2}$ implied the presence of 1,3,5-hexatriene 593, resulting from an antarafacial 1,7-H shift from the initial triene 590. It is noteworth that the ringclosure of 1,3,5-hexatriene $\mathbf{5 9 3}$ is highly diastereoselective. Diene $\mathbf{5 9 2}$ could also be obtained from $\mathbf{5 8 9}$ via a two-step sequence, with the initial 1,3-H shift promoted by an acid.

An application ${ }^{154}$ of this 1,3-H-1,7-H shift in tandem with [4+2] cycloaddition was explored (Scheme 163). Reactions of allenamides 594, containing a $Z$-allyl group, led to the desired tricyclic products 596a and 596b as single isomers through a highly stereoselective [4+2] cycloaddition of cyclic 1-amido-diene intermediate $\mathbf{5 9 5}$ after the 1,3-H-1,7-H shift. In contrast, the 1,7-shift was suppressed in reactions of allenamide 597, containing an $E$-allyl group. In this case, tricyclic products 599a and 599b were obtained in excellent yield and diastereoselectivity. This reaction can be carried out thermally in a triple tandem manner commencing from 597. These tandem processes provide a rapid assembly of complex tricycles from simple allenamides, demonstrating their tremendous synthetic potential.

Hsung ${ }^{155}$ later described a diastereoselective $6 \pi$-electrocyclic ring-closure employing halogensubstituted 3-amidotrienes via a 1,6-remote asymmetric induction (Scheme 164). This process utilized electrophilic halogenations of a-substituted allenamides 600, and 2halo-3-amido-di- and -trienes $\mathbf{6 0 1}$ were prepared in synthetically useful overall yields with 
$E$-stereoselectivity under optimized conditions. These reactions were thought to proceed through $N$-acyl iminium ions $\mathbf{6 0 2}$.

The successful de novo synthesis of these chiral 2-halo-3-amidotrienes enabled the diastereoselective $6 \pi$-electron electrocyclizations via a challenging remote 1,6-asymmetric induction ${ }^{155}$ (Scheme 165). While simple thermal conditions failed, addition of $\mathrm{AlMe}_{3}$ effectively promoted the electrocyclization of 603 , leading to the desired cyclic products 604 in good to excellent yields with overall good diastereoselectivity. A potential model is proposed as shown in TS-604 to rationalize the selectivity.

3.7.2. $\boldsymbol{\gamma}$-Isomerization-Hsung ${ }^{152 \mathrm{a}}$ also examined isomerizations or $1,3-\mathrm{H}$ shift of allenamides from the $\gamma$-position for the preparation of 1-amido-dienes (Scheme 166). Authors found that $1,3-\mathrm{H}$ shift of two types of $\gamma$-substituted allenamides with a cyclohexylidene group $\mathbf{6 0 5}$ and those with an iso-propylidene group $\mathbf{6 0 7}$ led to 1amidodienes 606 or 608 , respectively, as $E$-enamides exclusively. It was observed that acidic conditions appear to be more effective than thermal conditions. The thermal 1,3-H shift required higher temperatures and/or longer reaction times than those of aisomerizations. It is noteworthy again that related isomerization or 1,3-H shift from the $\gamma$ position has been documented by others ${ }^{25,52,111,152 b}$ (see Schemes 11, 19, and 107).

Hsung ${ }^{156}$ utilized the 1,3-H shift from the $\gamma$-position of allenamide for Oppolzer-type intramolecular Diels-Alder cycloadditions (Scheme 167). Fully functionalized allenamide 611 could be prepared from the copper catalyzed coupling between amide 609 and 1iodoallene 610. The authors found that allenamide $\mathbf{6 1 1}$ underwent effective base-mediated 1,3-H shift (see Trost's similar isomerization ${ }^{52}$ in Scheme 39 ) and Diels-Alder cycloaddition to give cycloadduct 612a in excellent yield. The cycloaddition was believed to proceed via an endo-transition state as shown in $\mathbf{6 1 3}$, leading to rapid assembly of a diverse array of $\mathrm{N}$ heterocyclic manifolds.

\section{Natural Product Synthesis}

Hsung ${ }^{157}$ documented a successful application of allenamide chemistry in the formal total synthesis of (+)-zincophorin 619 via an inverse electron-demand hetero-[4+2] cycloaddition of chiral allenamide 615 (Scheme 168). Heterodiene 614 and chiral allenamide 615 underwent highly stereoselective cycloaddition to afford pyran 616 as a single isomer. Pyran 616 underwent high-pressure hydrogenation of 616, which was not trivial, and the ensuing $\mathrm{SnBr}_{4}$-promoted crotylation with concomitant removal of the chiral urea group gave the key intermediate 617. It is noteworthy that in this entire sequence, the chiral auxiliary of allenamide $\mathbf{6 1 5}$ serves to provide stereochemical control for the cycloaddition and hydrogenation, and in return, the new stereocenters would dictate the selectivity of the final crotyalation and removal (and recovery) of the auxiliary. Pyran $\mathbf{6 1 7}$ was subsequently transformed into 618, which spectroscopically matched Miyashita's advanced intermediate, ${ }^{158}$ thereby constituting a formal total synthesis of (+)-zincophorin.

Hsung ${ }^{159}$ applied the highly stereoselective tandem sequence consisting of an allenic 1,3-H shift, $6 \pi$-electron pericyclic ring-closure and an intramolecular Diels-Alder cycloaddition as 
an approach toward the BCD-ring of atropurpuran (Scheme 169). Fully functionalized allenamide 622 was prepared from allylic bromide 620 and lithiated allenamide 621 . The desired 1,3-H shift was very fast and occurred with a catalytic amount of acid. The ringclosure of 623 and Diels-Alder cycloaddition took place in the presence of Lewis acid and high temperature to furnish the endo cycloadduct $\mathbf{6 2 6}$ as the desired product, although $d r$ was very modest. A series of standard but stereoselective transformation using cycloadduct $\mathbf{6 2 7}$ led to 631, which was unambiguously assigned to match the carbon skeleton of the BCD-ring of atropurpuran (Scheme 170).

Hegedus ${ }^{160}$ reported the first exercise of utilizing allenamides in natural product synthesis through achieving a synthesis of 1-deoxy-D-galactohomonojirimycin using an optically active allenamide 633 (Scheme 171). The Lewis acid catalyzed addition of 633 to aldehyde 632 produced aminotetraol 634 in excellent yield with > 95\% syn selectivity. After subsequent transformations including hydroboration/oxidation of silyl-alkyne, lactonization, auxiliary cleavage and deprotection of alcohol, amino-alcohol 635 was obtained in excellent overall yield. Mitsunobu cyclization of the alcohol $\mathbf{6 3 5}$ gave desired bicyclic amino lactone 636, which upon reduction and deprotection furnished the hydrochloride salt of 1-deoxy-Dgalactohomonojirimycin 637.

Vázquez and Domínguez ${ }^{85}$ described a novel approach to the tetracyclic unit of protoberberine using allenamide chemistry (Scheme 172). Allenamide 638 was subjected to acid catalyzed intramolecular electrophilic aromatic substitution via the $\mathrm{N}$-acyl iminium ion 639. The desired cyclization product 640 was obtained in good yield, and a subsequent 6exo Heck reaction of $\mathbf{6 4 0}$ furnished methylene protoberberine $\mathbf{6 4 1}$.

Lastly, Hsung ${ }^{147}$ illustrated an approach to parvineostemonine using a highly stereoselective $[4+3]$ cycloaddition reaction of nitrogen-stabilized oxyallyl cation derived from DMDOepoxidation of allenamide $\mathbf{6 4 2}$ with $N$-Boc-pyrrole (Scheme 173). The [4+3] cycloadduct 643 was obtained in excellent yield and essentially as a single diastereomer. Reduction of 643 followed by acid promoted removal of then Boc group and $\mathrm{N}$-allylation gave the tropanone intermediate 644. Allylations of 644 would furnish the bis-allyl intermediate 645, which was subjected to ring-closing metathesis condition to give $a z a$-tricycle 646 containing the $\mathrm{ABC}$-core of parvineostemonine.

\section{Most Recent Development}

In addition to attempts to prepare allenamides from ynamide-derived ${ }^{15}$ propargyl ester via Ireland-Claisen rearrangement ${ }^{30}$ (see Scheme 15), Carbery ${ }^{161}$ recently found that ynamidederived ${ }^{15}$ propargyl esters $\mathbf{3 2}$ could undergo an Au-catalyzed [3,3]-sigmatropic rearrangement to form allenamide intermediates 648 , which could be subjected to $1 H$-indole 647 trapping/proto-deauration sequence to afford $\gamma$-indolyl a-acyloxyenamides 650 (Scheme 174).

Charette ${ }^{162}$ recently reported a Rh(II) catalyzed cyclopropanation between $N$-phthaloyl derived allenamide $\mathbf{6 5 1}$ and a-cyano diazo ester $\mathbf{6 5 2}$ to afford diacceptor alkylidene cyclopropyl amide $\mathbf{6 5 3}$ (Scheme 175). This cyclopropanation took place regioselectively at 
the less-hindered terminal double bond with high $E / Z$ ratio and high $e e$ when using $\mathrm{Rh}_{2}(\mathrm{~S}$ $\mathrm{IBAZ}_{4}$ as the catalyst through carbenoid $\mathbf{6 5 4}$.

\section{Conclusion}

It is clear that the field of allenamide chemistry has received an increasingly growing attention in the past 15 years. This review has showcased these elegant developments from many dozens of research groups around the world. These innovative transformations have rendered allenamide a highly versatile building in organic synthesis and led to diverse array of carbo- and heterocyclic structures that can serve as platforms for further transformations. There is no doubt the level of interest in allenamides from the synthetic community is immensely high, and there is a tremendous amount of momentum to continue demonstrating the synthetic utility and applications of allenamides and taking their chemistry to the highest level of visibility. We hope this review can serve as another starting point for the allenamide chemistry.

\section{References}

1. For a compendium on chemistry of allenes, see: Krause N, Hashmi ASK. Modern Allene Chemistry. 2004WeinheimWiley-VCH Verlag GmbH \& Co. KGaAVol. 1 and Vol. 2.

2. For earlier reviews see: Sainsbury M. Rodd's Chemistry of Carbon Compounds. 1991OxfordElsevier:115-155. Schuster HE, Coppola GM. Allenes in Organic Synthesis. 1984New YorkJohn Wiley and Sons

3. For other general reviews on allenes, see: Brummond KM, Kent JL. Tetrahedron. 2000; 56:3263. Ma S. Chem. Rev. 2005; 105:2829. [PubMed: 16011326]

4. Saalfrank, RW.; Lurz, CJ. Methoden Der Organischen Chemie (Houben-Weyl). Kropf, H.; Schaumann, E., editors. Stuttgart: Georg Thieme Verlag; 1993. p. 3093-3102.

5. For leading reviews on chemistry of allenol ethers: Brasholz M, Reissig H-U, Zimmer R. Acc. Chem. Res. 2009; 42:45. [PubMed: 18921986] Zimmer R. Synthesis. 1993:165.

6. For a leading review on chemistry of allenyl sulfides: Hayashi Y, Narasaka K. Lautens M. Advances in Cycloaddition. 1997LondonJAI Press Ltd.:41-86.

7. Hubert AJ, Viehe HG. J. Chem. Soc. C. 1968:228.

8. (a) For the earliest documentations, see: Bode J. Ann. 1892; 267:268-286. (b) For a correction of this claim see: Klages F, Drerup E. Ann. 1941; 547:65.

9. For practical synthesis of ynamines, see: Zaugg HE, Swett LR, Stone GR. J. Org. Chem. 1958; 23:1389. Wolf V, Kowitz F. Ann. 1960; 638:33. Viehe HG. Angew Chem. Int. Ed. Engl. 1963; $2: 477$.

10. For reviews on chemistry of ynamines, see: Hsung RP, Zificsak CA, Mulder JA, Rameshkumar C, Wei L-L. Tetrahedron. 2001; 57:7575-7606. Himbert G. Kropf H, Schaumann E. Methoden Der Organischen Chemie (Houben-Weyl). 1993StuttgartGeorg Thieme Verlag:3267-3443. CollardMotte J, Janousek Z. Topics in Current Chem. 1986; 130:89. Pitacco G, Valentin E. Chemistry of Functional Groups. Chapter 15. 1979:623-714. Brandsma L, Verkruijse HD. Synthesis of Acetylenes, Allenes and Cumulenes. 1981AmsterdamElsevier Brandsma L, Verkruijsse HD. Stud. Org. Chem.: Amsterdam. 1981; 8 Ficini J. Tetrahedron. 1976; 32:448. Viehe HG. Chemistry of Acetylenes. Chapter 12. 1969New YorkMarcel Dekker:861-912. Viehe HG. Angew Chem. Int. Ed. Engl. 1967; 6:767.

11. Dickinson WB, Lang PC. Tetrahedron Lett. 1967; 8:3035.

12. Cho AK, Haslett WL, Jenden D. Biochem. Biophys. Res. Commun. 1961; 5:276. [PubMed: 13693213]

13. (a) Bebbington A, Shakeshaft D. J. Med. Chem. 1965; 8:274. [PubMed: 14332685] (b) Archibald JL. J. Med Chem. 1965; 8:390. [PubMed: 14323156] 
14. (a) Janousek Z, Collard J, Viehe HG. Angew. Chem. Int. Ed. Engl. 1972; 11:917.(b) Goffin E, Legrand Y, Viehe HG. J. Chem. Res. (S). 1977:105.

15. For leading reviews on chemistry of ynamides, see: DeKorver K, Li H, Lohse A, Hayashi R, Lu Z, Zhang Y, Hsung R. Chem. Rev. 2010; 110:5064. [PubMed: 20429503] Evano G, Coste A, Jouvin K. Angew. Chem. Int. Ed. 2010; 49:2840.

16. Also see: (a) Reference 10a. Katritzky AR, Jiang R, Singh SK. Heterocycles. 2004; 63:1455. Mulder JA, Kurtz KCM, Hsung RP. Synlett. 2003:1379. Ackermann L, Potukuchi HK. Org. Biomol. Chem. 2010; 8:4503. [PubMed: 20733972]

17. For reviews on chemistry of enamides, see: Carbery DR. Org. Biomol. Chem. 2008; 9:3455. [PubMed: 19082143] Rappoport Z. The Chemistry of Enamines in The Chemistry of Functional Groups. 1994New YorkJohn Wiley and Sons Also see: Overman LE. Acc. Chem. Res. 1980; 13:218. Petrzilka M. Synthesis. 1981:753. Campbell AL, Lenz GR. Synthesis. 1987:421. Krohn K. Angew. Chem. Int. Ed. Engl. 1993; 32:1582. Enders D, Meyer O. Liebigs Ann. 1996:1023.

18. Wei L-L, Xiong H, Hsung RP. Acc. Chem. Res. 2003; 36:773. [PubMed: 14567711]

19. Tracey, MR.; Hsung, RP.; Antoline, JA.; Kurtz, KCM.; Shen, L.; Slafer, BW.; Zhang, Y. Science of Synthesis, Houben-Weyl Methods of Molecular Transformations. Weinreb, Steve M., editor. Stuttgart, Germany: Georg Thieme Verlag KG; 2005. Chapter 21.4

20. Also see: Standen PE, Kimber MC. Curr. Opin. Drug Discov. \& Devel. 2010; 13:645. Deagostino A, Prandi C, Tabasso S, Venturello P. Molecules. 2010; 15:2667. [PubMed: 20428072]

21. Bogentoft C, Ericsson Ö, Stenberg P, Danielsson B. Tetrahedron Lett. 1969; 10:4745.

22. Corbel B, Paugam J-P, Dreux M, Savignac P. Tetrahedron Lett. 1976; 17:835.

23. Balasubramanian KK, Venugopalan B. Tetrahedron Lett. 1974; 15:2643.

24. Balasubramanian KK, Venugopalan B. Tetrahedron Lett. 1974; 15:2645.

25. (a) Overman LE, Charles KM, Clizbe LA. Tetrahedron Lett. 1979; 20:599.(b) Overman LE, Clizbe LA, Freerks RL, Marlowe CK. J. Am. Chem. Soc. 1981; 103:2807.

26. (a) Padwa A, Cohen LA. J. Org. Chem. 1984; 49:399.(b) Romero NA, Klepser BM, Anderson CE. Org. Lett. 2012; 14:874. [PubMed: 22235809]

27. Danowitz AM, Taylor CE, Shrikian TM, Mapp AK. Org. Lett. 2010; 12:2574. [PubMed: 20438110]

28. (a) Yin G, Zhu Y, Zhang L, Lu P, Wang Y. Org. Lett. 2011; 13:940. [PubMed: 21348533] (b) Zhu Y, Yin G, Sun L, Lu P, Wang Y. Tetrahedron. 2012; 68:10194.(c) Zhu Y, Yin G, Hong D, Lu P, Wang Y. Org. Lett. 2011; 13:1024. [PubMed: 21268594]

29. Related [3,3] sigmatropic rearrangements, see: Swaminathan S, Narayan KV. Chem. Rev. 1971; 71:429. Ireland RE, Mueller RH. J. Am. Chem. Soc. 1972; 94:5897.

30. Heffernan SJ, Carbery DR. Tetrahedron Lett. 2012; 53:5180.

31. Tamura Y, Ikeda H, Mukai C, Morita I, Ikeda M. J. Org. Chem. 1981; 46:1732.

32. Bacci JP, Greenman KL, Van Vranken DL. J. Org. Chem. 2003; 68:4955. [PubMed: 12790609]

33. Armstrong A, Cooke RS, Shanahan SE. Org. Biomol. Chem. 2003; 1:3142. [PubMed: 14527143]

34. Armstrong A, Emmerson DPG. Org. Lett. 2009; 11:1547. [PubMed: 19254002]

35. (a) Padwa A, Caruso T, Nahm S, Rodriguez A. J. Am. Chem. Soc. 1982; 104:2865.(b) Galons H, Bergerat I, Combet-Farnoux C, Miocque M, Decodts G, Bram G. J. Chem. Soc., Chem. Comm. 1985:1730.

36. Radl S, Kovarova L, Holubek J. Collect. Czech. Chem. Commun. 1991; 56:439.

37. (a) Phadtare S, Zemlicka J. J. Am. Chem. Soc. 1989; 111:5925.(b) Phadtare S, Zemlicka J. J. Org. Chem. 1989; 54:3675.(c) Jones BCNM, Silverton JV, Simons C, Megati S, Nishimura H, Maeda Y, Mitsuya H, Zemlicka J. J. Med. Chem. 1995; 38:1397. [PubMed: 7731024]

38. Zemlicka J. Biochim. Biophys. Acta. 2002; 1587:276. [PubMed: 12084469]

39. (a) Katritzky AR, Ramer WH. J. Org. Chem. 1985; 50:852.(b) Galy GP, Elguero J, Vincent EJ, Galy AM, Barbe J. Synthesis. 1979:944.(c) Mahamoud A, Galy JP, Vincent EJ, Barbe J. Synthesis. 1981:917.(d) Reschi J, Salehi-Artimani RA. J. Heterocyclic Chem. 1989; 26:1083. 40. Hsung RP, Zificsak CA, Wei L-L, Douglas CJ, Xiong H, Mulder JA. Org. Lett. 1999; 1:1237. 
41. (a) Wei L-L, Mulder JA, Xiong H, Zificsak CA, Douglas CJ, Hsung RP. Tetrahedron. 2001; 57:459.(b) Wei L-L, Xiong H, Douglas CJ, Hsung RP. Tetrahedron Lett. 1999; 40:6903.(c) Xiong H, Tracey MR, Grebe TP, Mulder JA, Hsung RP, Wipf P, Smotryski J. Organic Syn. 2004; 81:147.

42. Xuárez L, Pellón RF, Fascio M, Montesano V, D'Accorso N. Heterocycles. 2004; 63:23.

43. Fenández I, Monterde MI, Plumet J. Tetrahedron Lett. 2005; 46:6029.

44. Garud DR, Ando H, Kawai Y, Ishihara H, Koketsu M. Org. Lett. 2007; 9:4455. [PubMed: 17892295]

45. Van Boxtel LJ, Körbe S, Noltemeyer M, De Meijere A. Eur. J. Org. Chem. 2001:2283.

46. Huang J, Xiong H, Hsung RP, Rameshkumar C, Mulder JA, Grebe TP. Org. Lett. 2002; 4:2417. [PubMed: 12098261]

47. Zhang Z, Zhang Q, Ni Z, Liu Q. Chem. Comm. 2010; 46:1269. [PubMed: 20449273]

48. (a) Tanaka H, Kameyama Y, Sumida S, Yamada T, Tokumaru Y, Shiroi T, Sasaoka M, Taniguchi M, Torii S. Synlett. 1991:888.(b) Farina V, Kant J. Tetrahedron Lett. 1992; 33:3559.

49. (a) Majumdar KC, Ghosh SK. Synthetic Commun. 1994; 24:217.(b) Clay MD, Fallis AG. Angew. Chem. Int. Ed. 2005; 44:4039.

50. Kimura M, Wakamiya Y, Horino Y, Tamaru Y. Tetrahedron Lett. 1997; 38:3963.

51. (a) Kozawa Y, Mori M. Tetrahedron Lett. 2001; 42:4869.(b) Kozawa Y, Mori M. Tetrahedron Lett. 2002; 43:1499.

52. Trost BM, Stiles DT. Org. Lett. 2005; 7:2117. [PubMed: 15901148]

53. Shen L, Hsung RP, Zhang Y, Antoline JE, Zhang X. Org. Lett. 2005; 7:3081. [PubMed: 15987210]

54. Tang Y, Shen L, Dellaria BJ, Hsung RP. Tetrahedron Lett. 2008; 49:6404. [PubMed: 19890378]

55. Persson AKÅ, Johnston EV, Bäckvall J-E. Org. Lett. 2009; 11:3814. [PubMed: 19670851]

56. Cao J, Kong Y, Deng Y, Lai G, Cui Y, Hu Z, Wang G. Org. Biomol. Chem. 2012; 10:9556. [PubMed: 23117193]

57. Miyaura N, Suzuki A. J. Chem. Soc. Chem. Comm. 1979:866.

58. Xiong H, Hsung RP, Wei L-L, Berry CR, Mulder JA, Stockwell B. Org. Lett. 2000; 2:2869. [PubMed: 10964386]

59. Horino Y, Takata Y, Hashimoto K, Kuroda S, Kimurab M, Tamaru Y. Org. Biomol. Chem. 2008; 6:4105. [PubMed: 18972040]

60. (a) Skucas E, Zbieg JR, Krische MJ. J. Am. Chem. Soc. 2009; 131:5054. [PubMed: 19317402] (b) Zbieg JR, McInturff EL, Krische MJ. Org. Lett. 2010; 12:2514. [PubMed: 20459077]

61. Radl S, Kovarova L. Collect. Czech. Chem. Commun. 1991; 56:2413.

62. Manzo AM, Perboni AD, Broggini G, Rigamonti M. Tetrahedron Lett. 2009; 50:4696.

63. Broggini G, Galli S, Rigamonti M, Sottocornola S, Zecchi G. Tetrahedron Lett. 2009; 50:1447.

64. Hill AW, Elsegood MRJ, Kimber MC. J. Org. Chem. 2010; 75:5406. [PubMed: 20670040]

65. Beccalli EM, Broggini G, Clerici F, Galli S, Kammerer C, Rigamonti M, Sottocornola S. Org. Lett. 2009; 11:1563. [PubMed: 19260702]

66. Beccalli EM, Bernasconi A, Borsini E, Broggini G, Rigamonti M, Zecchi G. J. Org. Chem. 2010; 75:6923. [PubMed: 20863085]

67. Broggini G, Borsini E, Fasana A, Poli G, Liron F. Eur. J. Org. Chem. 2012:3617.

68. Watanabe T, Oishi S, Fujii N, Ohno H. Org. Lett. 2007; 9:4821. [PubMed: 17924641]

69. Kimber MC. Org. Lett. 2010; 12:1128. [PubMed: 20143846]

70. Singh S, Elsegood MRJ, Kimber MC. Synlett. 2012; 23:565.

71. Oishi S, Hatano K, Tsubouchi A, Takeda T. Chem. Comm. 2011; 47:11639. [PubMed: 21922084]

72. Hirata Y, Inui T, Nakao Y, Hiyama T. J. Am. Chem. Soc. 2009; 131:6624. [PubMed: 19378963]

73. Kumareswaran R, Shin S, Gallou I, Rajanbabu TV. J. Org. Chem. 2004; 69:7157. [PubMed: 15471465]

74. Gaul C, Seebach D. Helv. Chim. Acta. 2002; 85:963.

75. (a) Ranslow PBD, Hegedus LS, de los Ríos C. J. Org. Chem. 2004; 69:105. [PubMed: 14703385]

(b) de los Ríos C, Hegedus LS. J. Org. Chem. 2005; 70:6541. [PubMed: 16050728] 
76. Hyland CJT, Hegedus LS. J. Org. Chem. 2005; 70:8628. [PubMed: 16209626]

77. Alouane N, Bernaud F, Marrot J, Vrancken E, Mangeney P. Org. Lett. 2005; 7:5797. [PubMed: 16354069]

78. Wu Y-K, Niu T, West FG. Chem. Comm. 2012; 48:9186. [PubMed: 22864235]

79. Nilsson BM, Hacksell U. J. Heterocyclic Chem. 1989; 26:269.

80. Kant J, Farina V. Tetrahedron Lett. 1992; 33:3563.

81. Gericke R, Lues I. Tetrahedron Lett. 1992; 33:1871.

82. Noguchi M, Okada H, Watanabe M, Okuda K, Nakamura O. Tetrahedron. 1996; 52:6581.

83. Le Strat F, Maddaluno J. Org. Lett. 2002; 4:2791. [PubMed: 12153236]

84. Berry CR, Hsung RP, Antoline JE, Petersen ME, Rameshkumar C, Nielson JA. J. Org. Chem. 2005; 70:4038. [PubMed: 15876094]

85. Navarro-Vázquez A, Rodríguez D, Martínez-Esperón MF, García A, Saá C, Domínguez D. Tetrahedron Lett. 2007; 48:2741.

86. Husinec S, Markovic R, Petkovic M, Nasufovic V, Savic V. Org. Lett. 2011; 13:2286. [PubMed: 21446664]

87. Polindara-García LA, Miranda LD. Org. Lett. 2012; 14:5408. [PubMed: 23098177]

88. Domling A, Ugi I. Angew. Chem. Int. Ed. 2000; 39:3168.

89. Grigg R, Sridharan V, Xu L-H. J. Chem. Soc. Chem. Comm. 1995:1903.

90. Grigg R, Sansano JM. Tetrahedron. 1996; 52:13441.

91. Grigg R, Loganathan V, Sridharan V, Stevenson P, Sukirthalingam S, Worakun T. Tetrahedron. 1996; 52:11479.

92. Grigg R, Sansano JM, Santhakumar V, Sridharan V, Thangavelanthum R, Thornton-Pett M, Wilson D. Tetrahedron. 1997; 53:11803.

93. Fretwell P, Grigg R, Sansano JM, Sridharan V, Sukirthalingam S, Wilson D, Redpath J. Tetrahedron. 2000; 56:7525.

94. (a) Gardiner M, Grigg R, Sridharan V, Vicker N. Tetrahedron Lett. 1998; 39:435.(b) Gardiner M, Grigg R, Kordes M, Sridharan V, Vicker N. Tetrahedron. 2001; 57:7729.

95. Grigg R, Köppen I, Rasparini M, Sridharan V. Chem. Comm. 2001:964.

96. Grigg R, McCaffrey S, Sridharan V, Fishwick CWG, Kilner C, Korn S, Bailey K, Blacker J. Tetrahedron. 2006; 62:12159.

97. Husinec S, Petkovic M, Savic V, Simic M. Synthesis. 2012; 44:399.

98. Fuwa H, Sasaki M. Org. Biomol. Chem. 2007; 5:2214. [PubMed: 17609751]

99. Inamoto K, Yamamoto A, Ohsawa K, Hiroya K, Sakamoto T. Chem. Pharm. Bull. 2005; 53:1502. [PubMed: 16272743]

100. Parthasarathy K, Jeganmohan M, Cheng C-H. Org. Lett. 2006; 8:621. [PubMed: 16468726]

101. Fuwa H, Tako T, Ebine M, Sasaki M. Chem. Lett. 2008; 37:904.

102. Persson AKÅ, Bäckvall J-E. Angew. Chem. Int. Ed. 2010; 49:4624.

103. Brummond KM, Yan B. Synlett. 2008:2303.

104. Hyland CJT, Hegedus LS. J. Org. Chem. 2006; 71:8658. [PubMed: 17064053]

105. González-Gómez A, Domínguez G, Pérez-Castells J. Eur. J. Org. Chem. 2009:5057.

106. Ma Z-X, He S, Song W, Hsung RP. Org. Lett. 2012; 14:5736. [PubMed: 23121692]

107. Shen L, Hsung RP. Org. Lett. 2005; 7:775. [PubMed: 15727438]

108. (a) Braverman S, Segev D. J. Am. Chem. Soc. 1974; 96:1245.(b) Garratt PJ, Neoh SB. J. Am. Chem. Soc. 1975; 97:3255.(c) Mondal S, Mitra T, Mukherjee R, Addy PS, Basak A. Synlett. 2012; 23:2582.

109. Mukherjee R, Basak A. Synlett. 2012; 23:877.

110. Zhou H, Xing Y, Yao J, Lu Y. J. Org. Chem. 2011; 76:4582. [PubMed: 21557630]

111. Kinderman SS, Van Maarseveen JH, Schoemaker HE, Hiemstra H, Rutjes FPT. Org. Lett. 2001; 3:2045. [PubMed: 11418045]

112. Rameshkumar C, Xiong H, Tracey MR, Berry CR, Yao LJ, Hsung RP. J. Org. Chem. 2002; 67:1339. [PubMed: 11846684] 
113. Lu T, Hayashi R, Hsung RP, DeKorver KA, Lohse AG, Song Z, Tang Y. Org. Biomol. Chem. 2009; 7:3331. [PubMed: 19641792]

114. (a) Kimura M, Horino Y, Wakamiya Y, Okajima T, Tamaru Y. J. Am. Chem. Soc. 1997; 119:10869.(b) Horino Y, Kimura M, Tanaka S, Okajima T, Tamaru Y. Chem.-Eur. J. 2003; 9:2419. [PubMed: 12794887]

115. Kimura M, Horino Y, Mori M, Tamaru Y. Chem.-Eur. J. 2007; 13:9686. [PubMed: 17768719]

116. Nair V, Sethumadhavan D, Nair SM, Shanmugam P, Treesa PM, Eigendorf GK. Synthesis. 2002:1655.

117. Li X-X, Zhu L-L, Zhou W, Chen Z. Org. Lett. 2012; 14:436. [PubMed: 22201372]

118. Faustino H, Bernal P, Castedo L, López F, Mascareñas JL. Adv. Syn. Cat. 2012; 354:1658.

119. Suárez-Pantiga S, Hernández-Díaz C, Piedrafita M, Rubio E, Gonzáleza JM. Adv. Synth. Catal. 2012; 354:1651.

120. Anorbe L, Poblador A, Dominguez G, Pérez-Castells J. Tetrahedron Lett. 2004; 45:4441.

121. González-Gómez Á, Añorbe L, Poblador A, Domínguez G, Pérez-Castells J. Eur. J. Org. Chem. 2008:1370.

122. Gupta AK, Park DI, Oh CH. Tetrahedron Lett. 2005; 46:4171.

123. Broggini G, Bruché L, Zecchi G. J. Chem. Soc. Perkin 1:. 1990:533.

124. Barluenga J, Vicente R, López LA, Tomas M. J. Am. Chem. Soc. 2006; 128:7050. [PubMed: 16719486]

125. Piperno A, Rescifina A, Corsaro A, Chiacchio MA, Procopio A, Romeo R. Eur. J. Org. Chem. 2007; 9:1517.

126. Chiacchio U, Corsaro A, Iannazzo D, Piperno A, Romeo G, Romeo R, Saita MG, Rescifina A. Eur. J. Org. Chem. 2007:4758.

127. Zhu Y, Wen S, Yin G, Hong D, Lu P, Wang Y. Org. Lett. 2011; 13:3553. [PubMed: 21661752]

128. Wei L-L, Hsung RP, Xiong H, Mulder JA, Nkansah NT. Org. Lett. 1999; 1:2145.

129. (a) Berry CR, Rameshkumar C, Tracey MR, Wei L-L, Hsung RP. Synlett. 2003:791.(b) Rameshkumar C, Hsung RP. Synlett. 2003:1241.

130. Berry CR, Hsung RP. Tetrahedron. 2004; 60:7629.

131. Lohse AG, Hsung RP. Org. Lett. 2009; 11:3430. [PubMed: 19591454]

132. Faustino H, López F, Castedo L, Mascareñas JL. Chem. Sci. 2011; 2:633.

133. Francos J, Grande-Carmona F, Faustino H, Iglesias-Sigüenza J, Díez E, Alonso I, Fernández R, Lassaletta JM, López F, Mascareñas JL. J. Am. Chem. Soc. 2012; 134:14322. [PubMed: 22892048]

134. Cao J, Huang X. Org. Lett. 2010; 12:5048. [PubMed: 20925422]

135. Zhu S, Cao J, Wu L, Huang X. J. Org. Chem. 2012; 77:1049.

136. Horino Y, Kimura M, Wakamiya Y, Okajima T, Tamaru Y. Angew. Chem. Int. Ed. 1999; 38:121.

137. Horino Y, Kimura M, Naito M, Tanaka S, Tamaru Y. Tetrahedron Lett. 2000; 41:3427.

138. Hashimoto K, Horino Y, Kuroda S. Heterocycles. 2010; 80:187.

139. Reviews about [3 + 3]: Buchanan GS, Feltenberger JB, Hsung RP. Curr. Org. Synth. 2010; 7:363. [PubMed: 20936076] Hsung RP, Kurdyumov AV, Sydorenko N. Eur. J. Org. Chem. 2005; 1:23. Hsung RP, Cole KP. Harmata M. Strategies and Tactics in Organic Synthesis. 2004; Oxford, UKElsevier Science, Pergamon4:41. Hsung RP, Wei LL, Sklenicka HM, Shen HC, McLaughlin MJ, Zehnder LR. Trends Heterocycl. Chem. 2001; 7:1.

140. Xiong H, Hsung RP, Berry CR, Rameshkumar C. J. Am. Chem. Soc. 2001; 123:7174. [PubMed: 11459504]

141. Recent reviews: Lohse AG, Hsung PR. Chem.-Eur. J. 2011; 17:3812. [PubMed: 21384451] Harmata M. Chem. Commun. 2010; 46:8904. Harmata M. Chem. Commun. 2010; 46:8886. Examples of amido-stablized: Magee DI, Godineau E, Thornton PD, Walters MA, Sponholtz DJ. Eur. J. Org. Chem. 2006:3667. Xiong H, Hsung RP, Shen L, Hahn JM. Tetrahedron Lett. 2002; 43:4449. Walters MA, Arcand HR. J. Org. Chem. 1996; 61:1478. Walters MA, Arcand HR, Lawrie DJ. Tetrahedron Lett. 1995; 36:23.

142. Antoline JE, Hsung RP. Synlett. 2008:739. 
143. Krenske EH, Houk KN, Lohse AG, Antoline JE, Hsung RP. Chem. Sci. 2010; 1:387. [PubMed: 21572919]

144. Lohse AG, Krenske EH, Antoline JE, Houk KN, Hsung RP. Org. Lett. 2010; 12:5506. [PubMed: 21049917]

145. Antoline JE, Krenske EH, Lohse AG, Houk KN, Hsung RP. J. Am. Chem. Soc. 2011; 133:14443. [PubMed: 21851070]

146. Du Y, Krenske EH, Antoline JE, Lohse AG, Houk KN, Hsung RP. J. Org. Chem. 2012 ASAP.

147. Antoline JE, Hsung RP, Huang J, Song Z, Li G. Org. Lett. 2007; 9:1275. [PubMed: 17335226]

148. Huang J, Hsung RP. J. Am. Chem. Soc. 2005; 127:50. [PubMed: 15631443]

149. Reviews: Harmata M. Adv. Synth. Catal. 2006; 348:2297. Hartung IV, Hoffmann HMR. Angew. Chem. Int. Ed. 2004; 43:1934. Examples: Lo B, Lam S, Wong WT, Chiu P. Angew. Chem. Int. Ed. 2012; 51:12120. Dai X, Davies HML. Adv. Synth. Catal. 2006; 348:2449. (formal 4+3). Harmata M, Ghosh SK, Hong X, Wacharasindhu S, Kirchhoefer P. J. Am. Chem. Soc. 2003; 125:2058. [PubMed: 12590528]

150. (a) Xiong H, Huang J, Ghosh SK, Hsung RP. J. Am. Chem. Soc. 2003; 125:12694. [PubMed: 14558802] (b) Lohse AG, Hsung RP, Leider MD, Ghosh SK. J. Org. Chem. 2011; 76:3246. [PubMed: 21449577]

151. Rameshkumar C, Hsung RP. Angew. Chem. Int. Ed. 2004; 43:615.

152. (a) Hayashi R, Hsung RP, Feltenberger JB, Lohse AG. Org. Lett. 2009; 11:2125. [PubMed: 19371081] (b) Farmer ML, Billups WE, Greenlee RB, Kurtz AN. J. Org Chem. 1966; 31:2885. (c) Basak A, Gupta SN, Chakrabarty K, Das GK. Comput. Theor. Chem. 2013; 1007:15.

153. Hayashi R, Feltenberger JB, Lohse AG, Walton MC, Hsung RP. Beil. J. Org. Chem. 2011; 7:410.

154. Hayashi R, Feltenberger JB, Hsung RP. Org. Lett. 2010; 12:1152. [PubMed: 20170149]

155. Hayashi R, Walton MC, Hsung RP, Schwab J, Yu X. Org. Lett. 2010; 12:5768. [PubMed: 21090590]

156. Feltenberger JB, Hsung RP. Org. Lett. 2011; 13:3114. [PubMed: 21612235]

157. (a) Song Z, Hsung RP. Org. Lett. 2007; 9:2199. [PubMed: 17480091] (b) Song Z, Hsung RP, Lu T, Lohse AG. J. Org. Chem. 2007; 72:9722. [PubMed: 17979293]

158. Komatsu K, Tanino K, Miyashita M. Angew. Chem. Int. Ed. 2004; 43:4341.

159. Hayashi R, Ma Z-X, Hsung RP. Org. Lett. 2012; 14:252. [PubMed: 22149386]

160. Achmatowicz M, Hegedus LS. J. Org. Chem. 2004; 69:2229. [PubMed: 15049613]

161. Heffernan SJ, Beddoes JM, Mahon MF, Hennessy AJ, Carbery DR. Chem. Comm. 2013

162. Lindsay VNG, Fiset D, Gritsch PJ, Azzi S, Charette AB. J. Chem. Soc. 2013; 135:1643.

\section{Biographies}

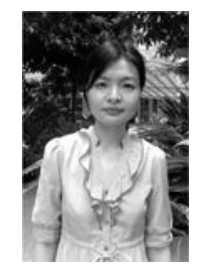

Ting Lu obtained her B.S. in Chemistry from Nankai University in China in 2002. She then went to National University of Singapore to obtain her M.S. degree in Materials Science in 2005. After that, she joined Professor Richard Hsung's research group in University of Minnesota-Twin Cities and then to University of Wisconsin-Madison, where she studied on the methodology development in cyclopropanations of enamides and allenamides, and got her Ph.D. degree in Organic Chemistry in 2009. Now she is working on new catalytic systems for the production of bio-renewable chemicals from biomass in Institute of 
Bioengineering and Nanotechnology, Agency for Science, Technology and Research, Singapore.

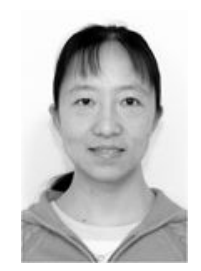

Zhenjie Lu obtained her B.S degree in chemistry in 1996 from the East China University of Science and Technology in Shanghai, China. She started as a graduate student at Michigan State University under Professor Bill Wulff's direction in 2002 as a graduate student and fished her Ph.D. degree in 2008. Her research involved studies on the optimization and synthetic application of catalytic asymmetric aziridination reactions.

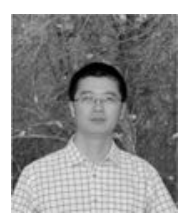

Zhi-Xiong Ma received a B.S. degree in chemistry from University of Science and Technology of China (USTC) in 2005. He carried out doctoral research under the supervision of Professor Gang Zhao at Shanghai Institute of Organic Chemistry (SIOC), CAS and obtained his Ph.D. degree in late 2010. Currently he is conducting postdoctoral research with Professor Richard Hsung at University of Wisconsin-Madison. His research interests include visible-light photoredox catalysis and natural product synthesis.

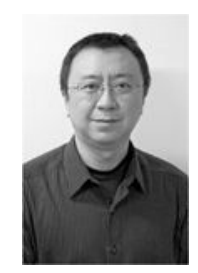

Yu Zhang received his B.S degree in chemistry in 1996 from East China University of Science and Technology in Shanghai, China. In 2000 he joined Professor Bill Wulff's group as a graduate student at Michigan State University. He obtained his Ph.D. degree in 2006 after working in the area of mechanism and methodology development of catalytic asymmetric aziridination. After spending one year at University of Maryland working for Professor Michael P. Doyle, from 2007 to 2009 he was a postdoctoral scholar at the University of Wisconsin at Madison, working with Professor Richard Hsung in the area of ynamide chemistry and natural product synthesis. He is currently a research scientist at Dow AgroSciences LLC. 


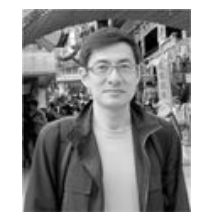

Richard P. Hsung obtained his B.S. in Chemistry and Mathematics from Calvin College in Grand Rapids, MI. He then attended The University of Chicago and received his M.S. and Ph.D. degrees in Organic Chemistry, respectively, under the supervision of Professors Jeff Winkler and Bill Wulff. After pursuing a postdoctoral stay with Professor Larry Sita in Chicago and NIH-postdoctoral work with Professor Gilbert Stork at Columbia University, he moved to University of Minnesota-Twin Cities as an Assistant Professor in 1997 and was promoted to Associate Professor in 2002. He was promoted to Professor and moved to University of Wisconsin-Madison in 2006. He was a recipient of the Camille Dreyfus Teacher-Scholar Award and the National Science Foundation Career Award. He has coauthored over 200 publications, delivered over 200 invited lectures, and supervised over 150 students and postdoctoral fellows with research interests in developing cycloaddition and annulation approaches to natural product syntheses and stereoselective methods using allenamides, ynamides, enamides, and cyclic acetals. 


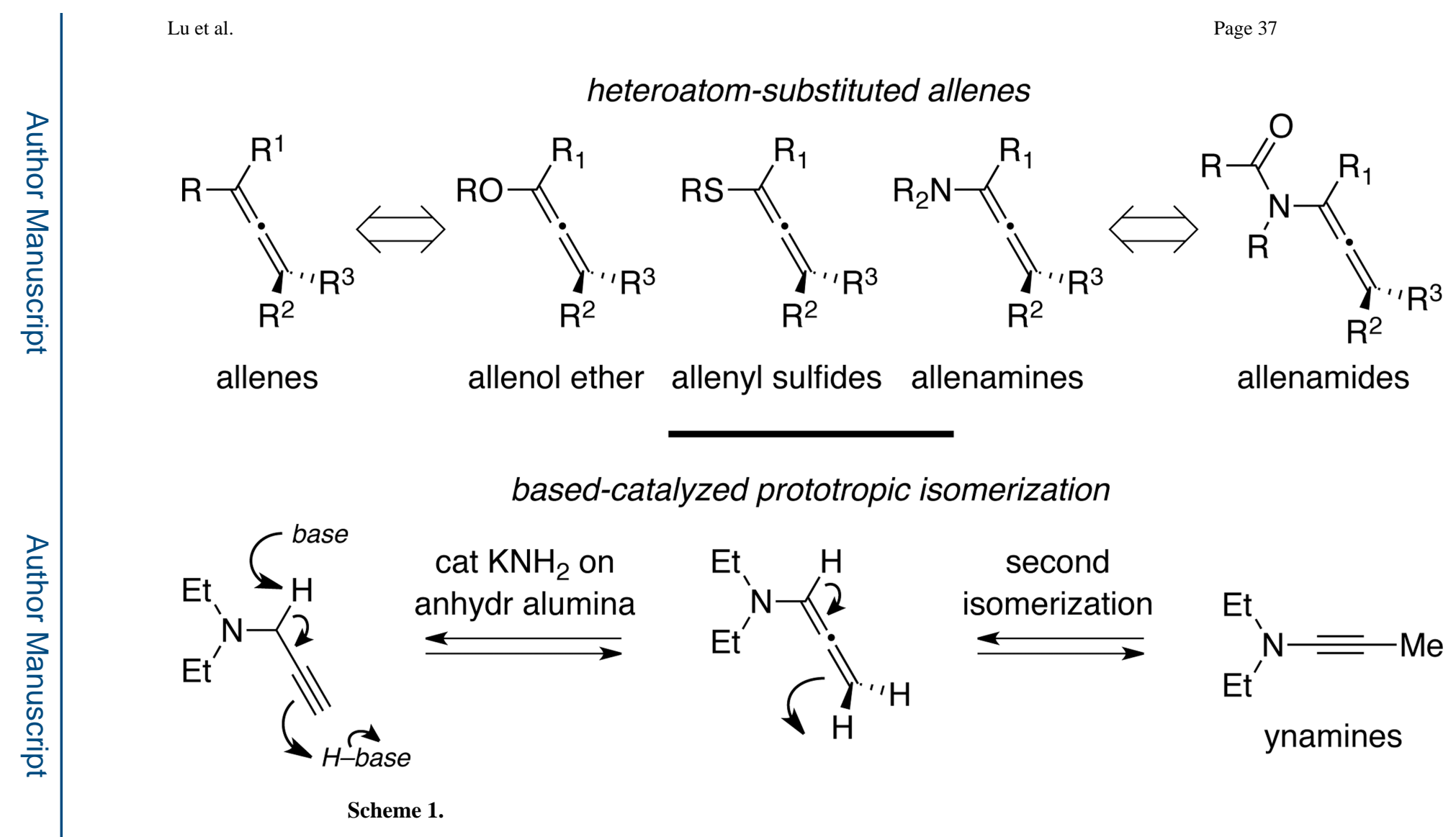


allenamine resonance forms
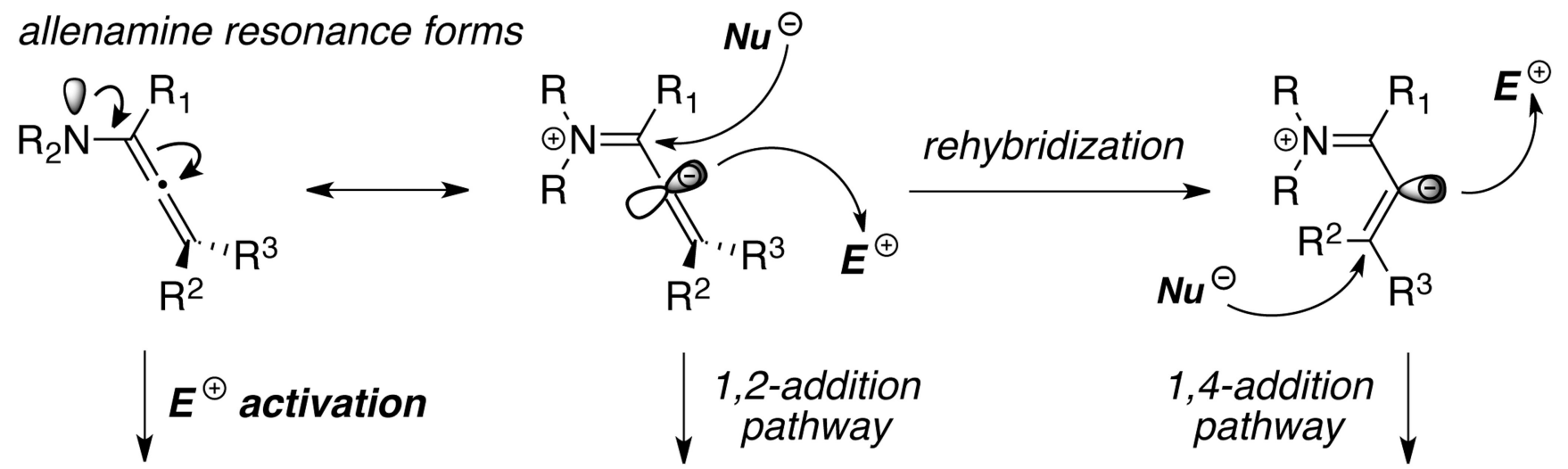<smiles>[R2]C([R])=C(F)C([R1])([Y19])N([R2])CC</smiles><smiles>[R]NC([R])=C(F)C([R])([R])[W]</smiles><smiles></smiles>
2-addition R $\mathrm{Nu}$

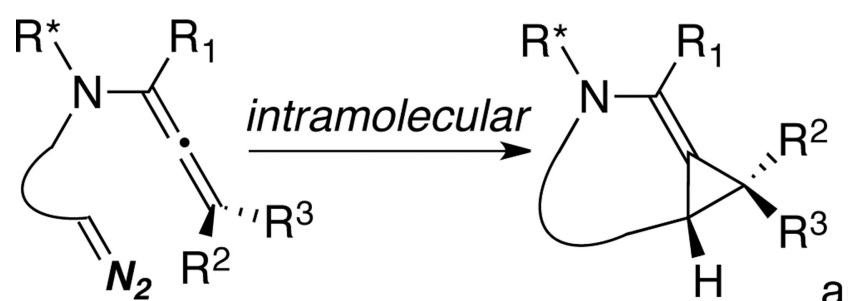

Scheme 2. 
allenamine resonance forms
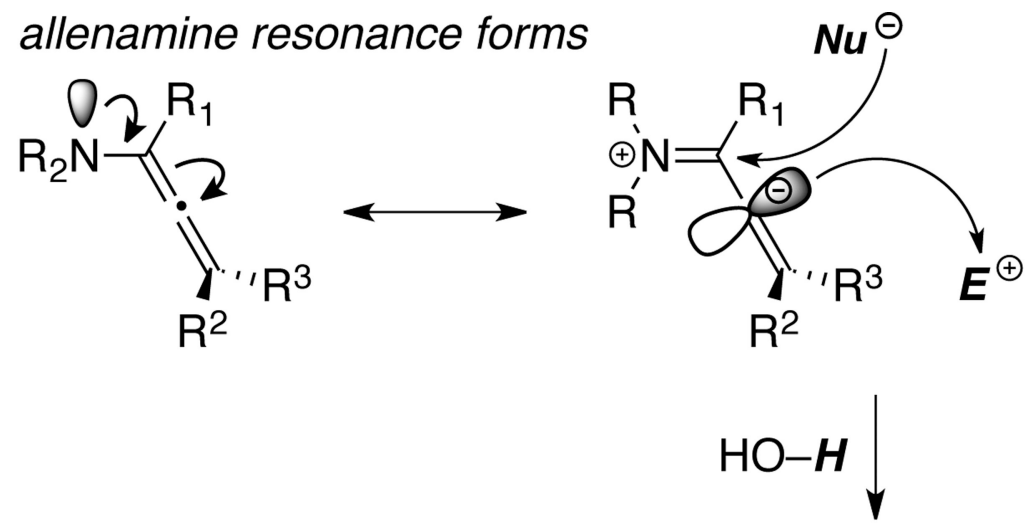

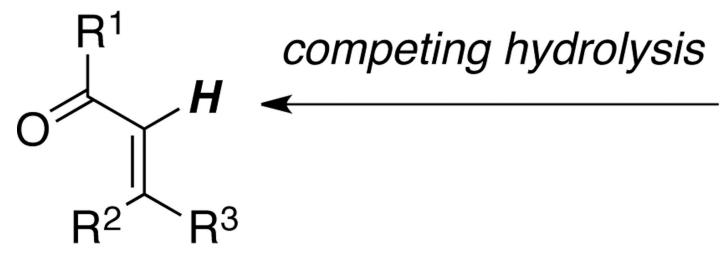<smiles>[R]C([R])=CC([R])([R])[NH]</smiles>

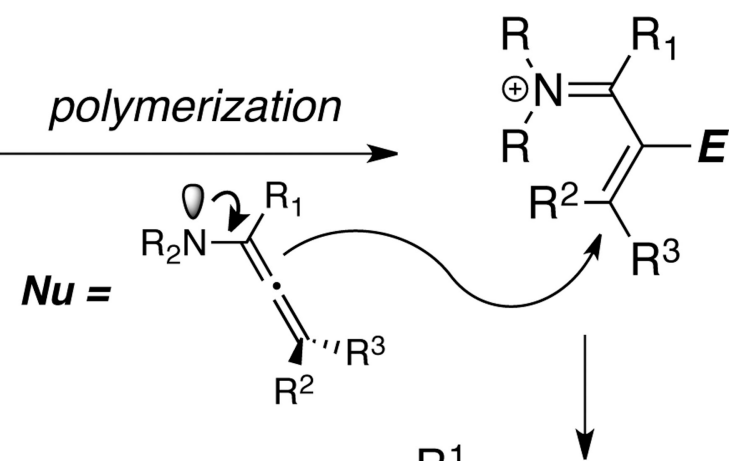

Scheme 3. 


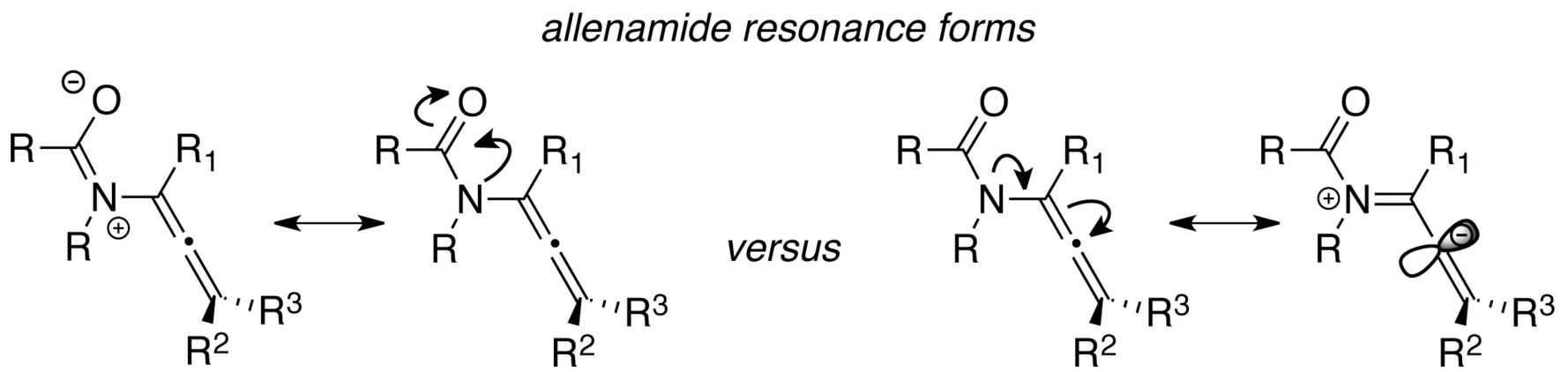

delocalization of the nitrogen lone pair is now diverted

Scheme 4. 


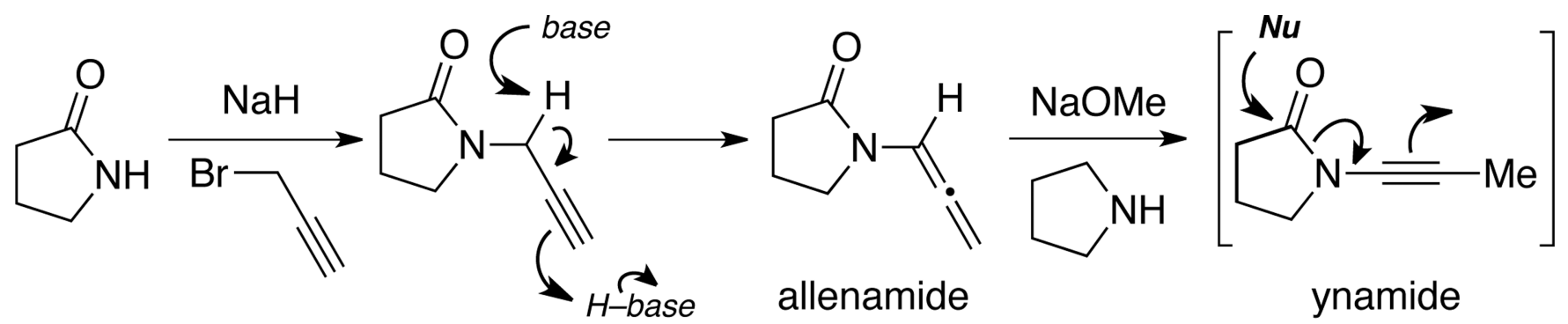<smiles>CCC1=NCCC1C(=O)N1CCCC1</smiles><smiles>CC(C)CC(C)CO</smiles><smiles>C/C=C1\NCCC1C(=O)N1CCCC1</smiles><smiles>CC=C1CC(C(=O)N2CCCC2)CCN1CC</smiles>

Scheme 5. 
<smiles>O=C1N[C@@H](P)CO1</smiles>

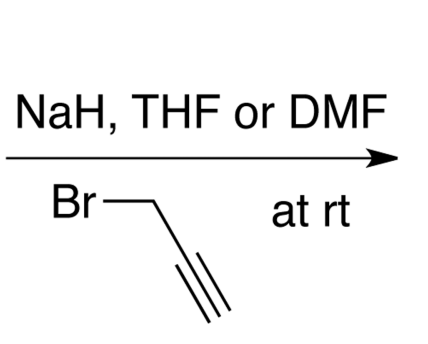

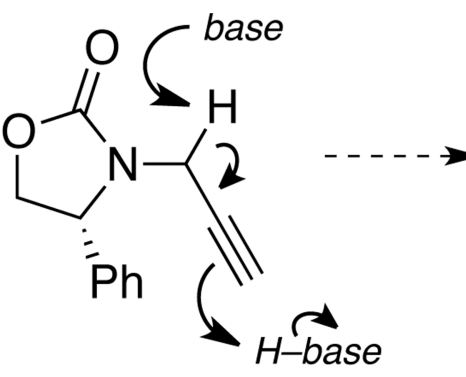

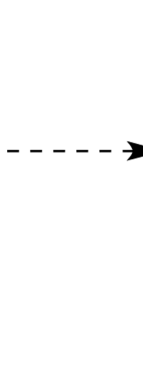<smiles>CC#CN1C(=O)OC[C@H]1c1ccccc1</smiles>

\section{chiral ynamide}

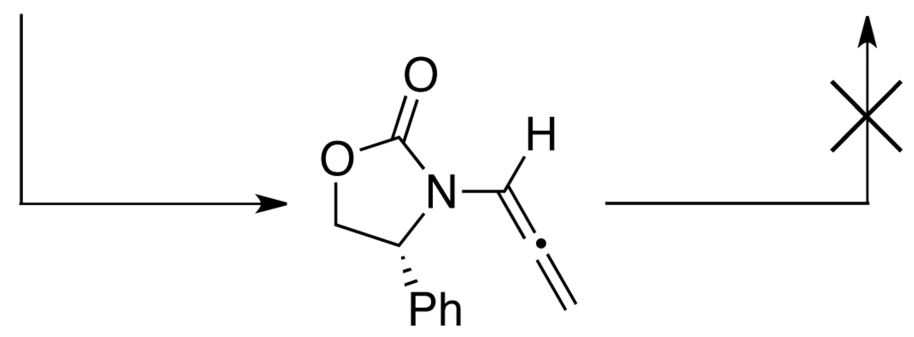

chiral allenamide

Scheme 6. 


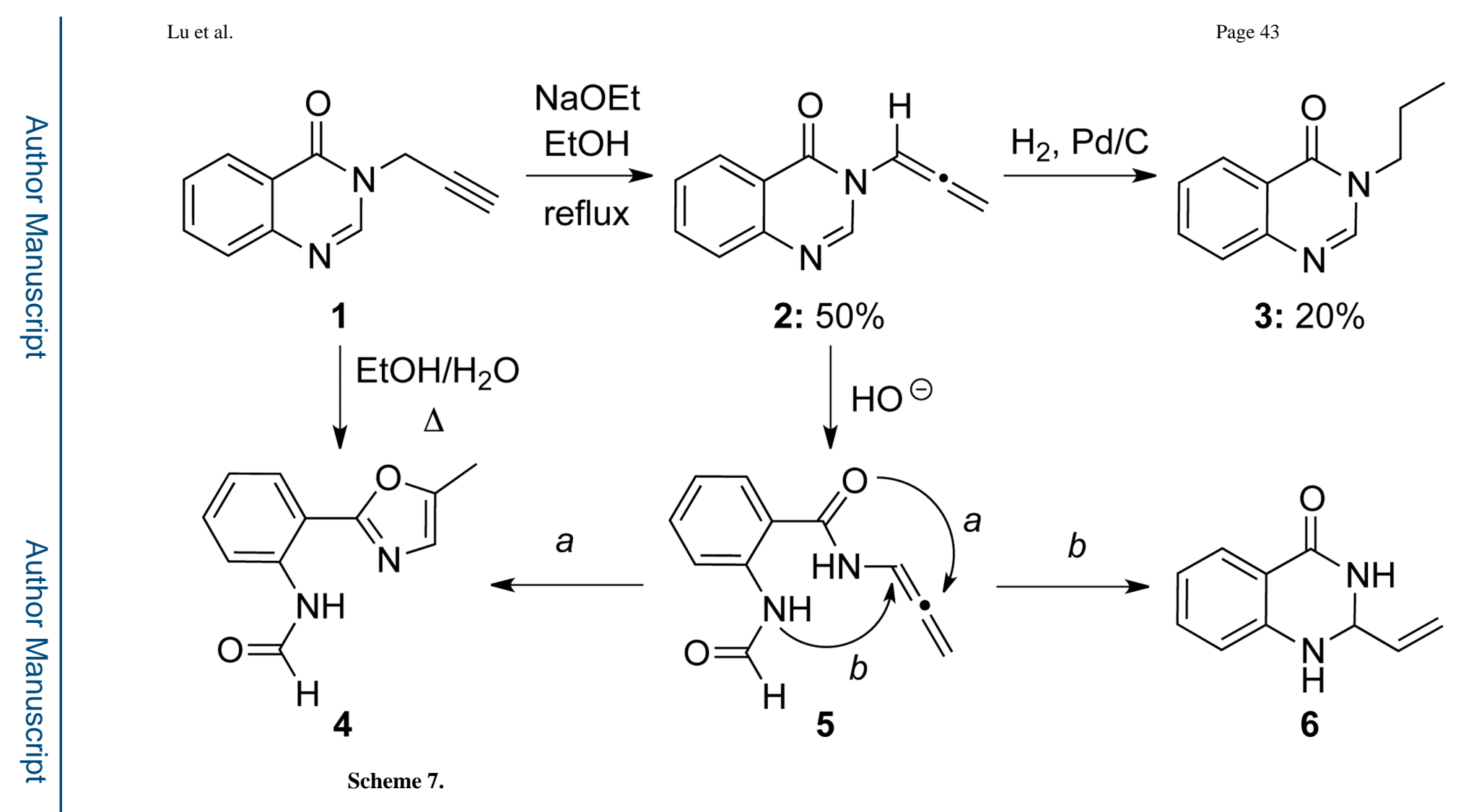


Lu et al.

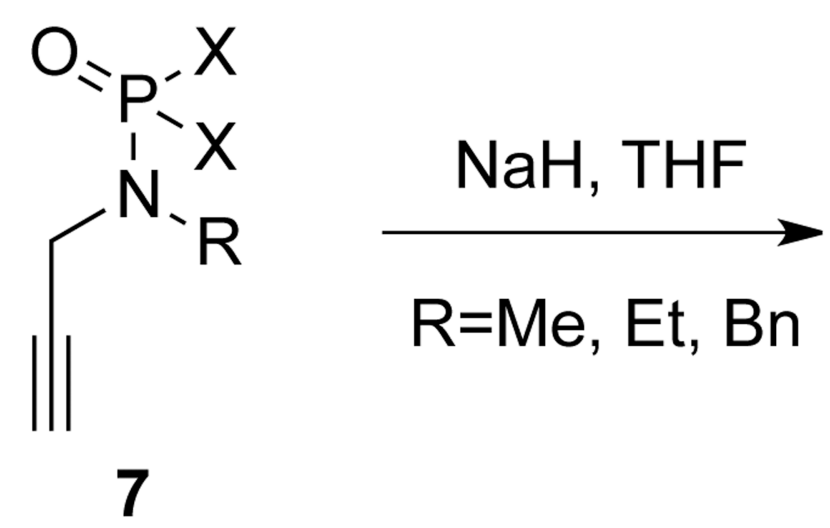

Page 44

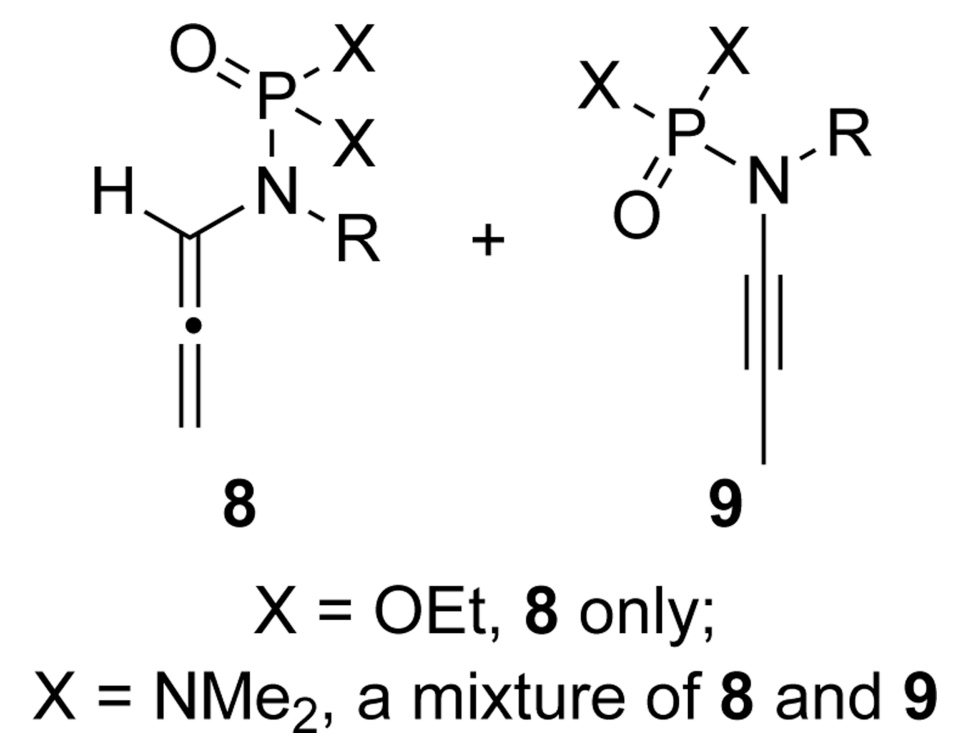

Scheme 8. 


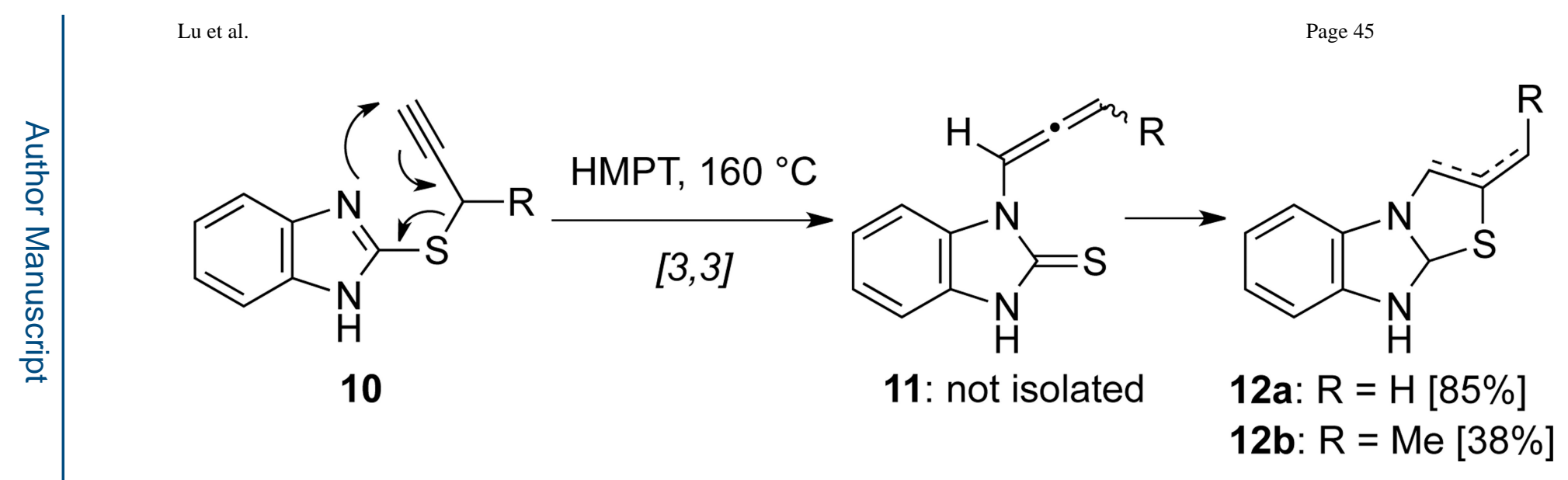

Scheme 9. 


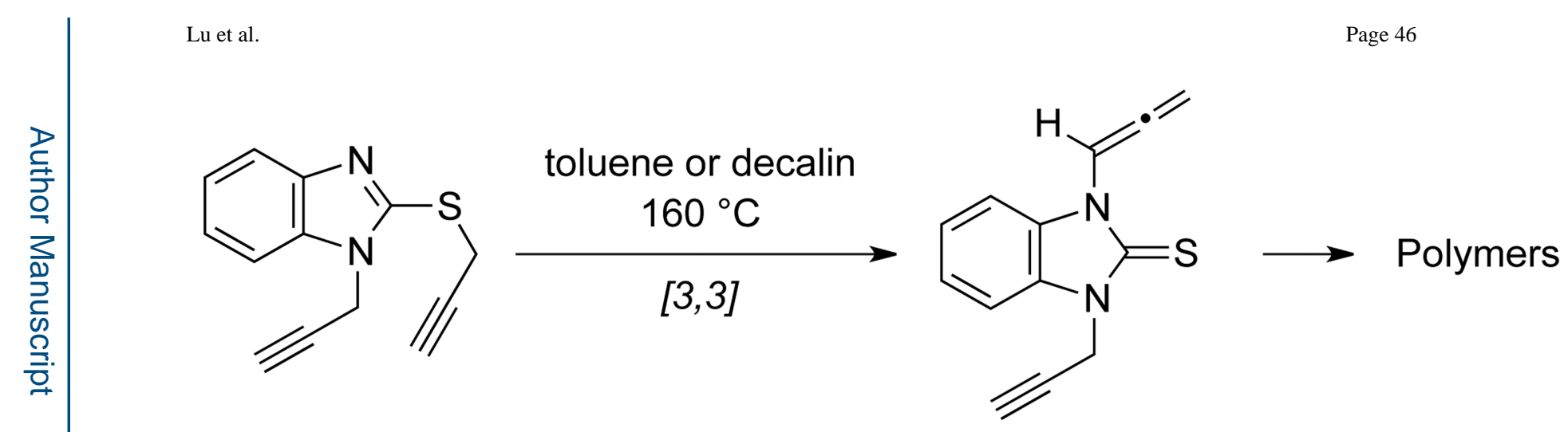

13

14: not isolated

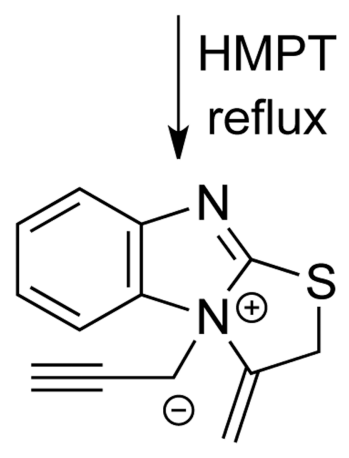

15

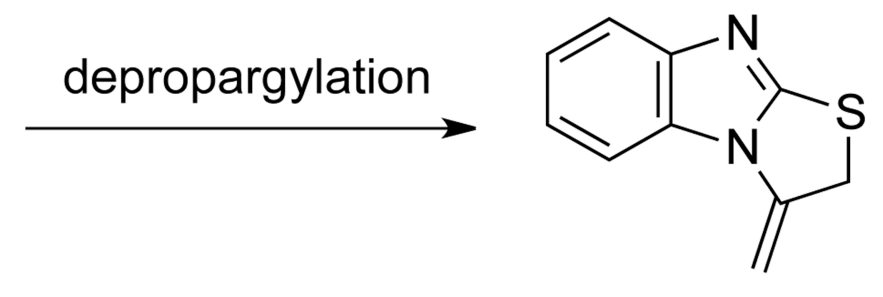

16: not isolated<smiles>Cc1csc2nc3ccccc3n12</smiles>

17: $30 \%$

Scheme 10. 


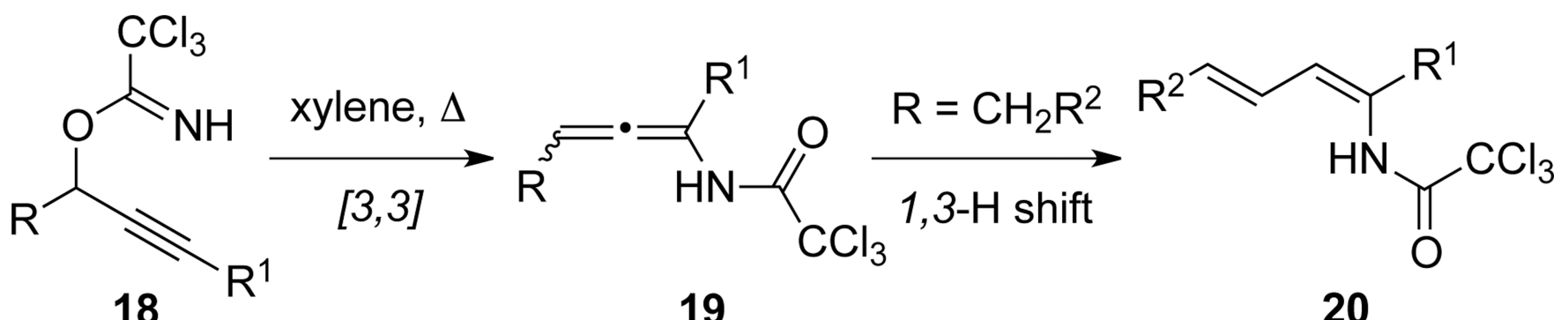

18

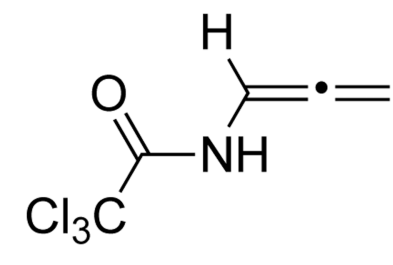

19a: $11 \%$<smiles>O=C([Te])N/C(=C\C=C\[10Br])C(Cl)(Cl)Cl</smiles>

19

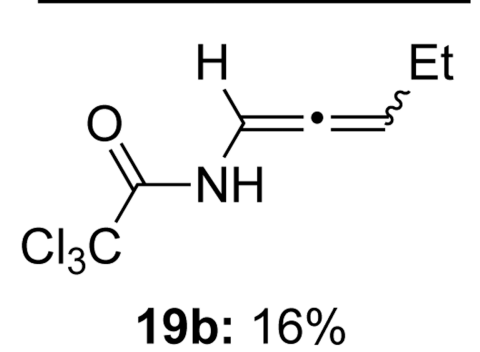

20a: $92 \%$

20b: $68 \%$<smiles>O=C([Mg])N/C(=C\C=C\c1ccccc1)C(Cl)(Cl)Cl</smiles>

Scheme 11.
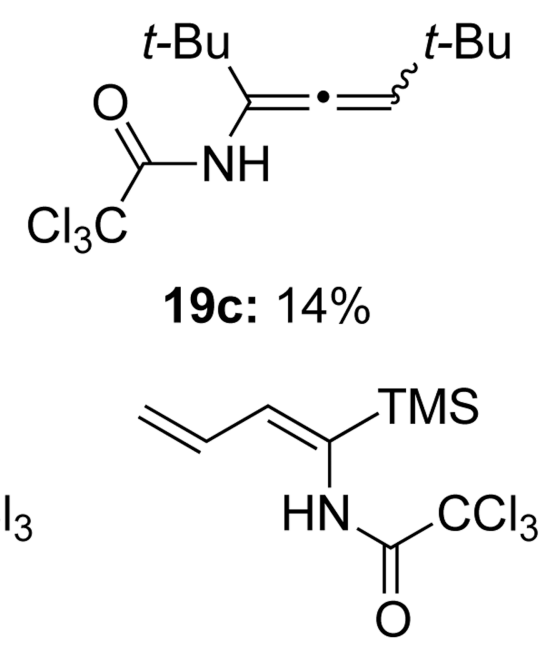

20c: $29 \%$ 
<smiles>c1ccccc1</smiles>

$21 a$<smiles>[R]C#CCOc1ccccn1</smiles>

22

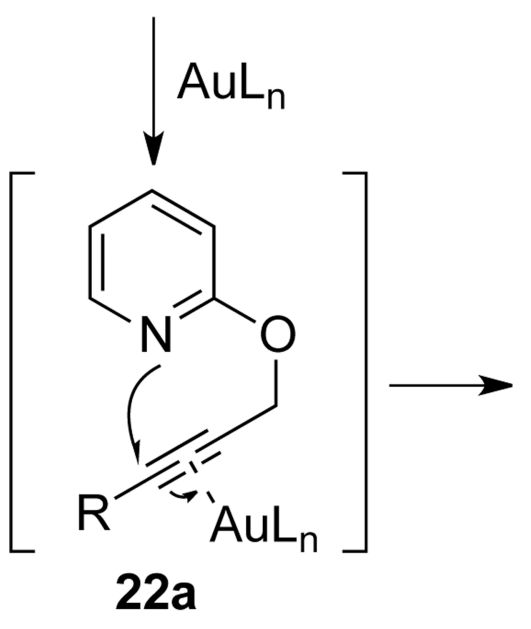

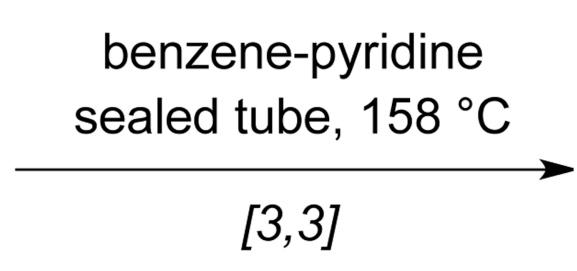

$5 \mathrm{~mol} \% \mathrm{NaAuCl}_{4} \cdot 2 \mathrm{H}_{2} \mathrm{O}$ $20 \mathrm{wt} \%$ Dowex, 1.5 equiv $\mathrm{NEt}_{3}$ $\mathrm{H}_{2} \mathrm{O} / \mathrm{EtOH}, 100{ }^{\circ} \mathrm{C}$

$$
\mathrm{R}=\text { Alkyl or aryl }
$$

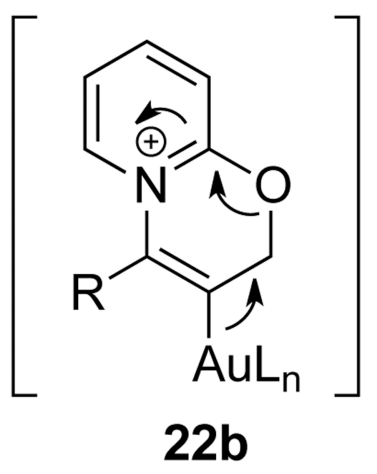<smiles>[R]C(C(C)=O)n1ccccc1=O</smiles>

23<smiles>C=C=Cn1c(-c2ccccc2)c(-c2ccccc2)oc1=O</smiles>

21b: $90 \%$<smiles>OCCO</smiles><smiles>[CH2]C(C)(C)C</smiles><smiles>[R]C(=C)n1ccccc1=O</smiles>
22c

\section{$[3,3]$}

Scheme 12. 


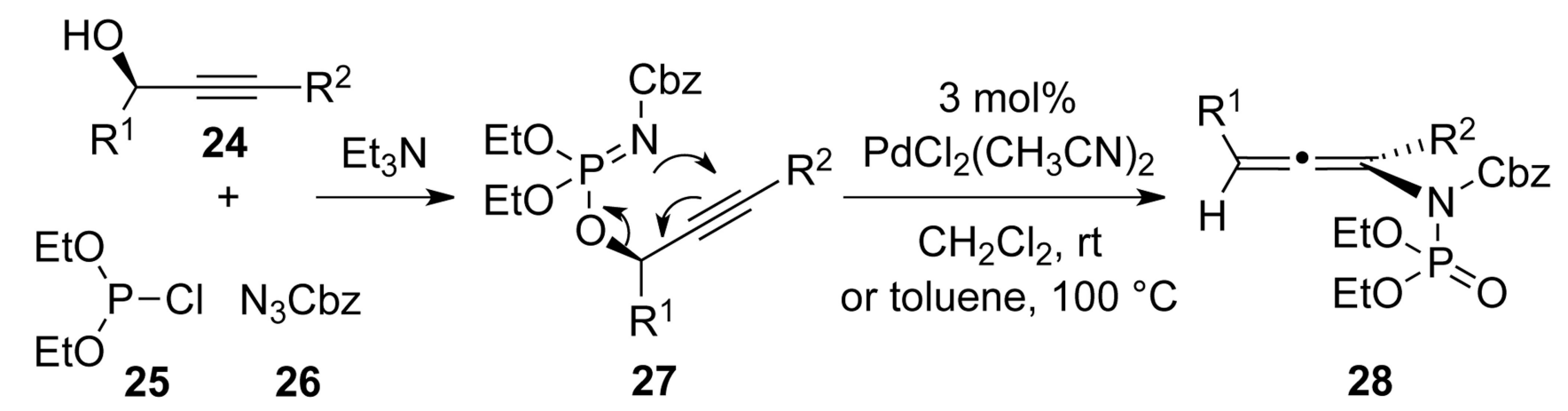<smiles>C=C=CN(C(=O)Cl)P(=O)(OCC)OCC</smiles>

28a: $76 \%$

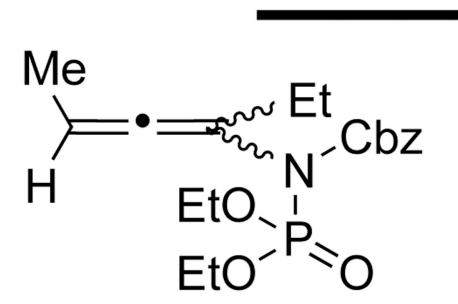

28b: $60 \%$

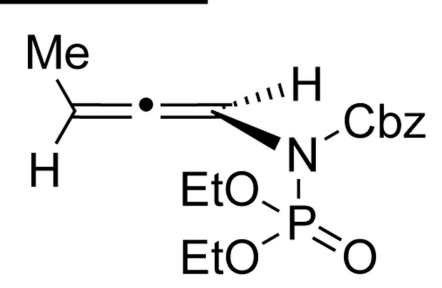

28c: $67 \%, 92 \%$ ee

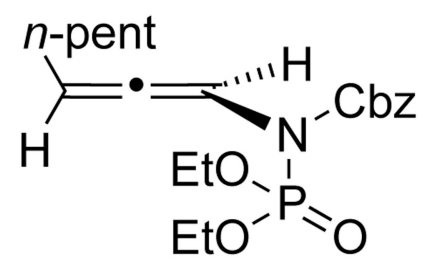

Scheme 13. 


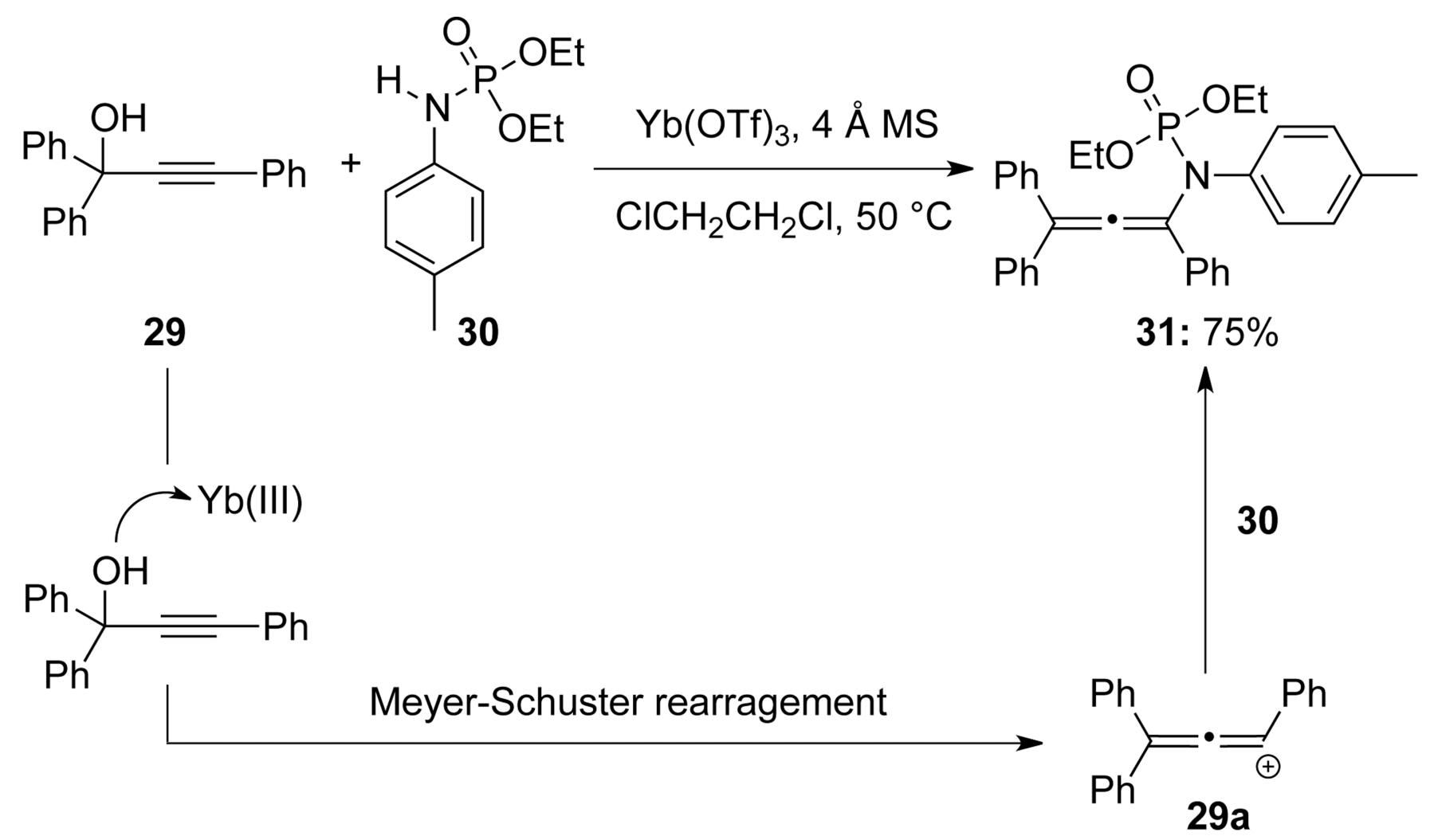

Scheme 14. 


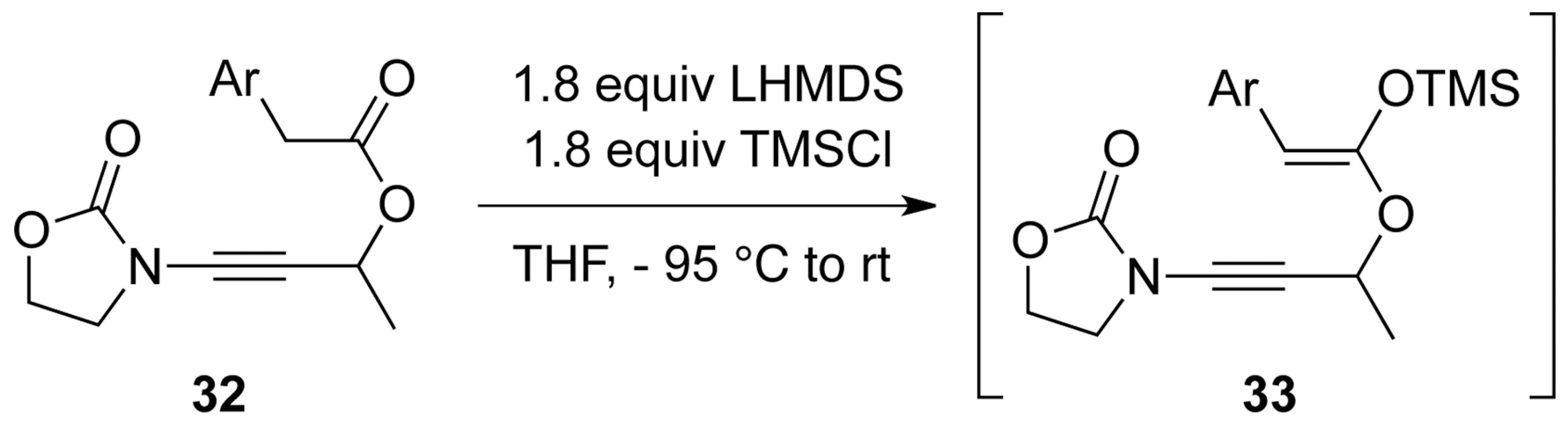

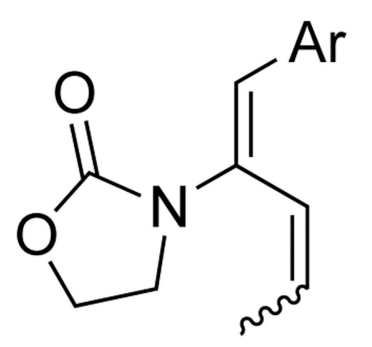

35: $42 \%$ to $69 \%$

ZIE 2:1 to >95:5
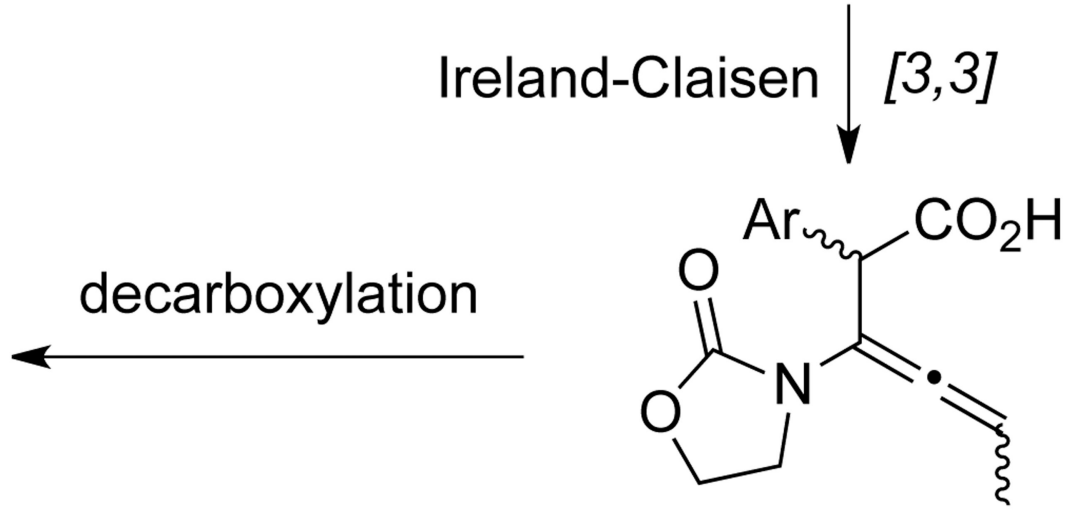

34: unable to isolate

Scheme 15. 


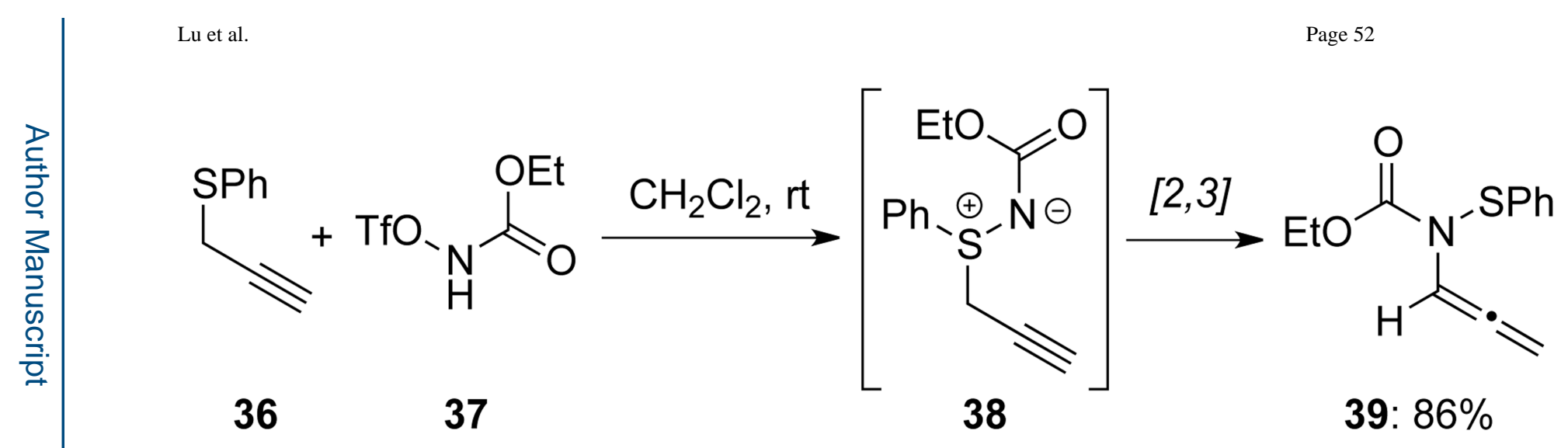

Scheme 16. 


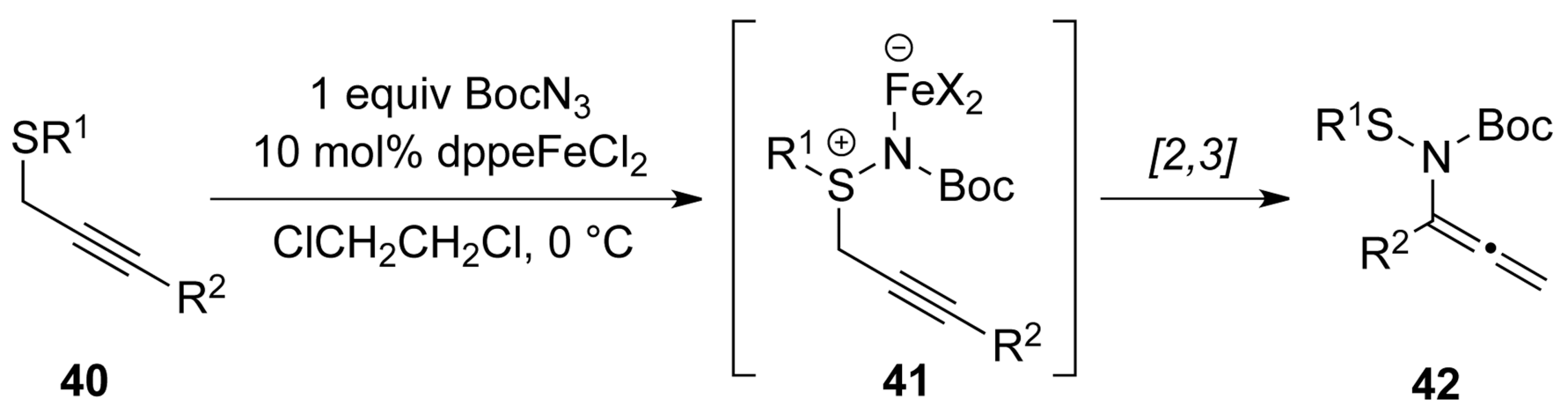<smiles>C=C=CN([PbH])[PbH]</smiles><smiles>C=C=C(C)N(C(=O)OCc1ccccc1)c1ccccc1</smiles><smiles>C=C=C([As])N([Pb])[Pb](=O)OC(C)(C)C</smiles><smiles>C=C=C(C(O)[Hg])N([PbH])C(=O)OC(C)(C)C</smiles>

42a: $73 \%$

42b: $70 \%$

42c: $52 \%$

42d: $53 \%$<smiles>CC=C=CN(Sc1ccccc1)C(=O)OC(C)(C)C</smiles>

42e: $52 \%$<smiles>C=C=C(C(OC(C)(C)C)c1ccccc1)N(SP)C(=O)OC(C)(C)C</smiles>

42f: $69 \%$<smiles>C=C=C(C)N(SCCc1ccccc1)C(=O)OC(C)(C)C</smiles>

42g: $31 \%$

Scheme 17. 
<smiles>[R]C#CC([R])S[R]</smiles>

43<smiles>[R6]N([SbH])C=C=C</smiles>

46a: $87 \%$<smiles>[R6]N([PbH])C(I)=C=C</smiles>

46d: $85 \%$<smiles>[R2]C#CC([R7])[S@]([R])(=O)N[R6]</smiles>

45

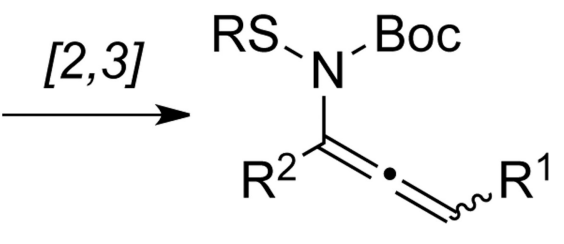

46<smiles>[Z7][R18](=O)C(=C=C)N([R6])[R6]</smiles>

46c: $66 \%$<smiles>[R6]N(S[R10]([H])[H])C(C)=C=CC</smiles>

46f: $13 \%$

Scheme 18. 

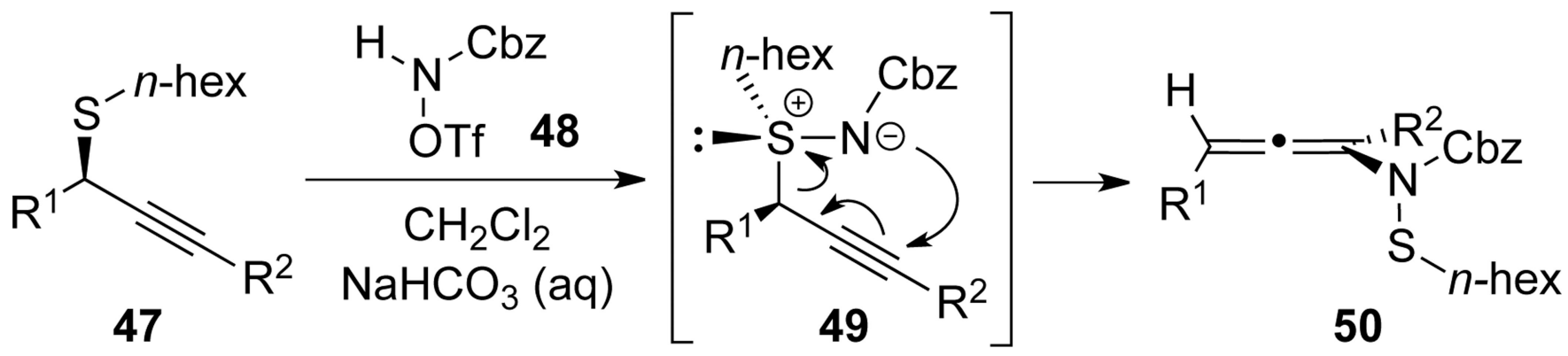

50<smiles>[R][R]OSN(C([R])=O)[C@H]([R])CO</smiles>

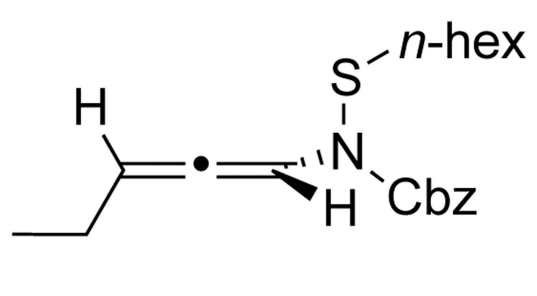

50a: $74 \%, 81 \%$ ee

50b: $76 \%, 87 \%$ ee
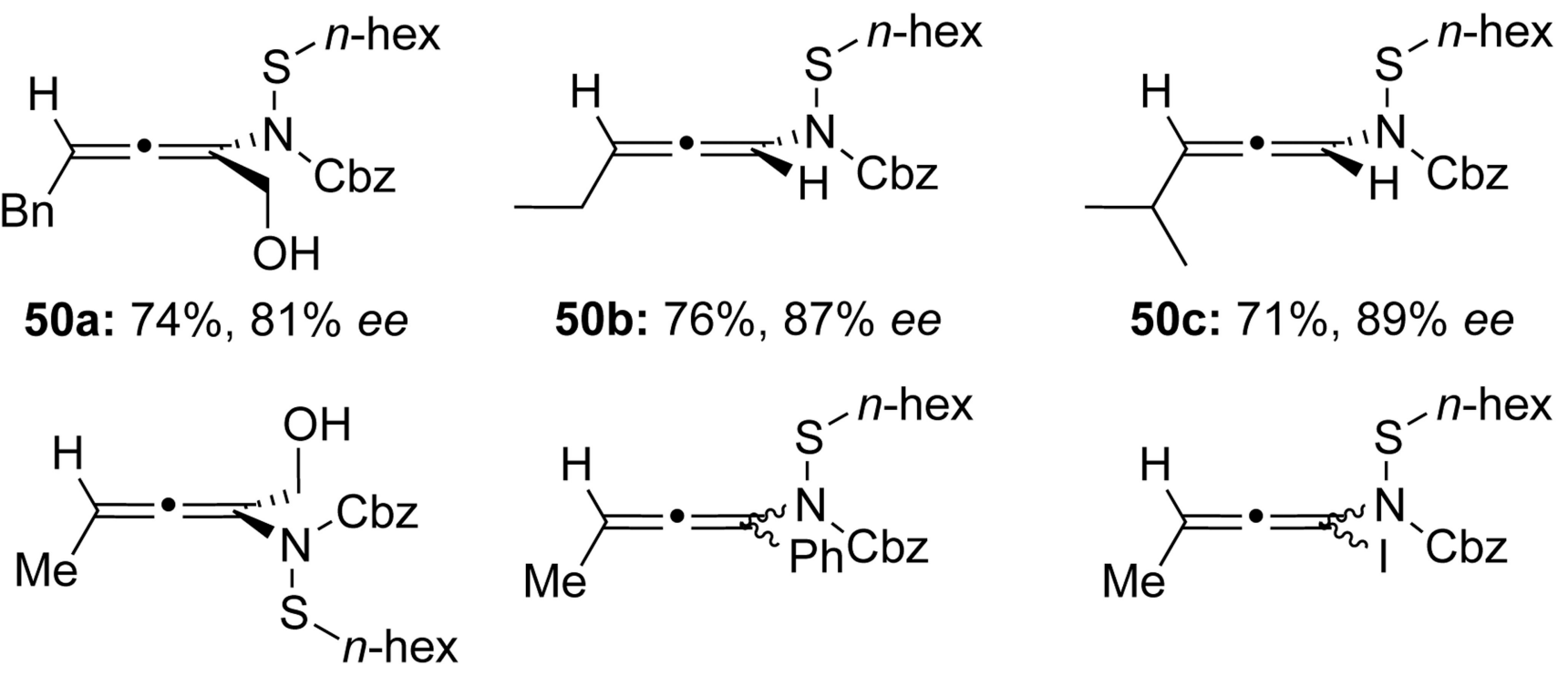

50c: $71 \%, 89 \%$ ee

50d: $84 \%, 93 \%$ ee

50e: $47 \%$

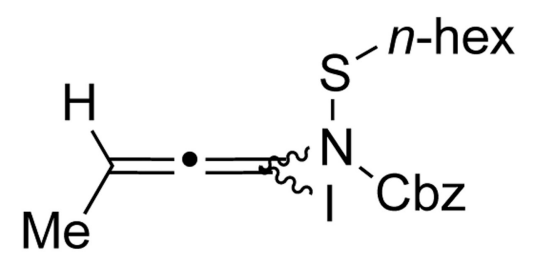

Scheme 19. 

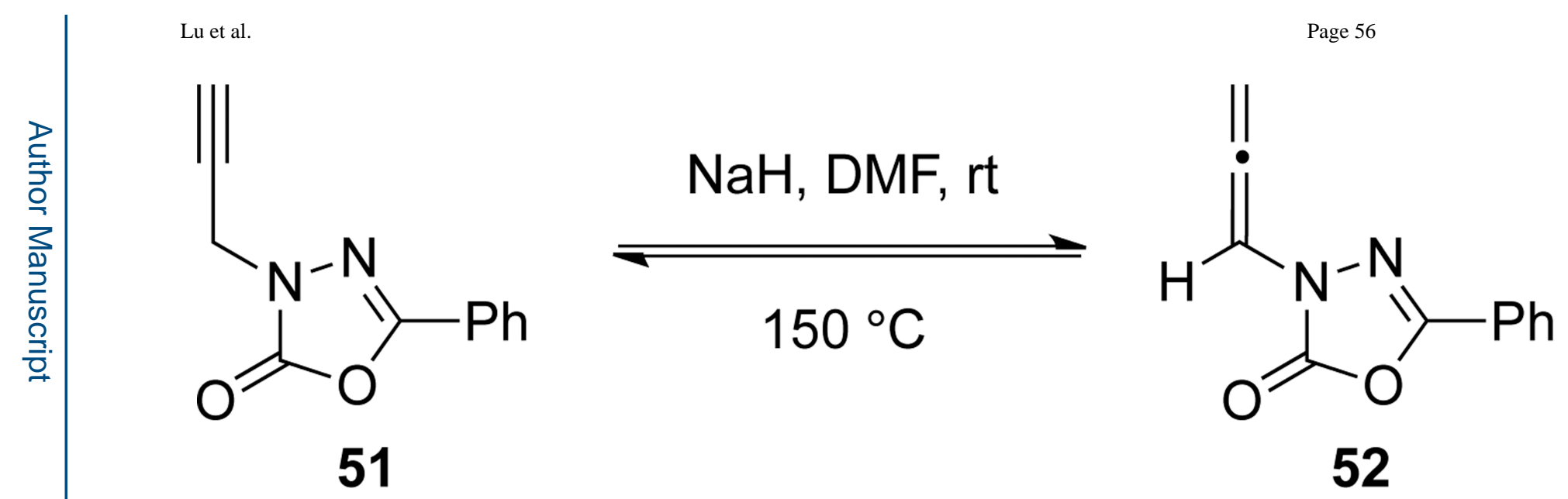

51

Scheme 20. 

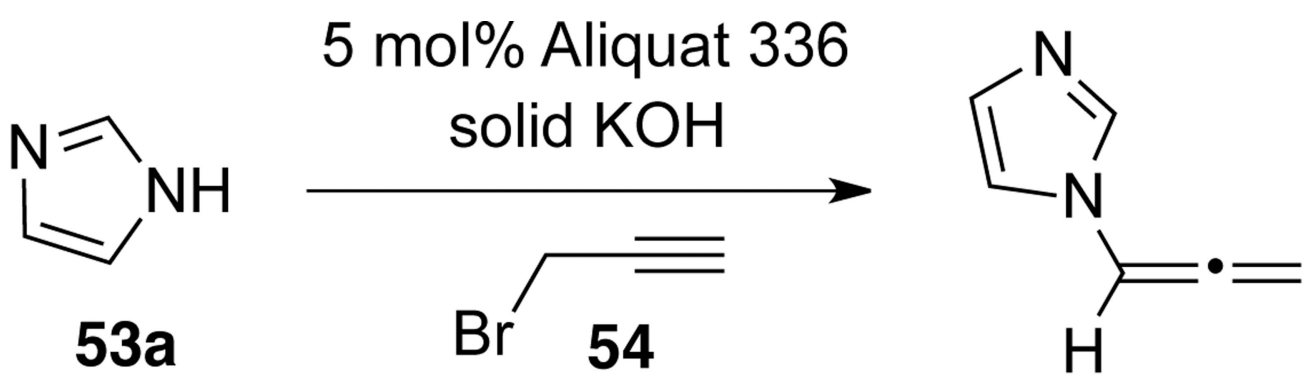

55a: $81 \%$
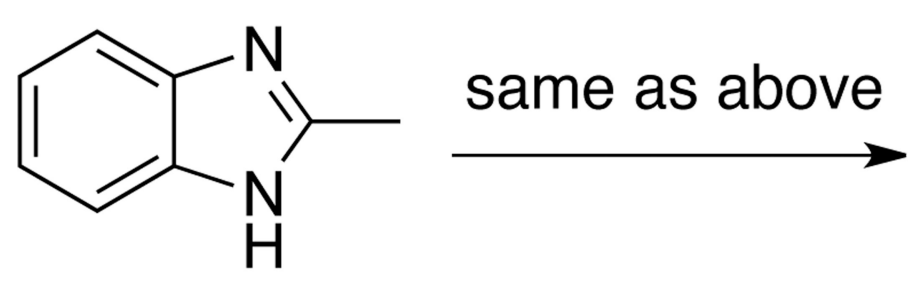

$53 b$

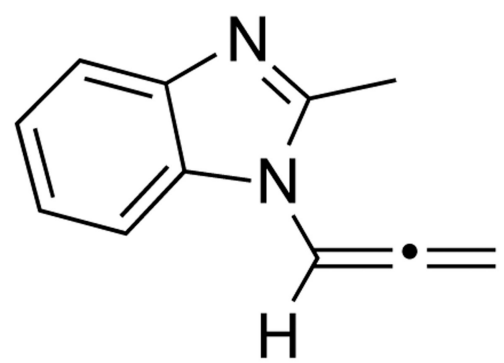

55b: $34 \%$

Scheme 21 . 


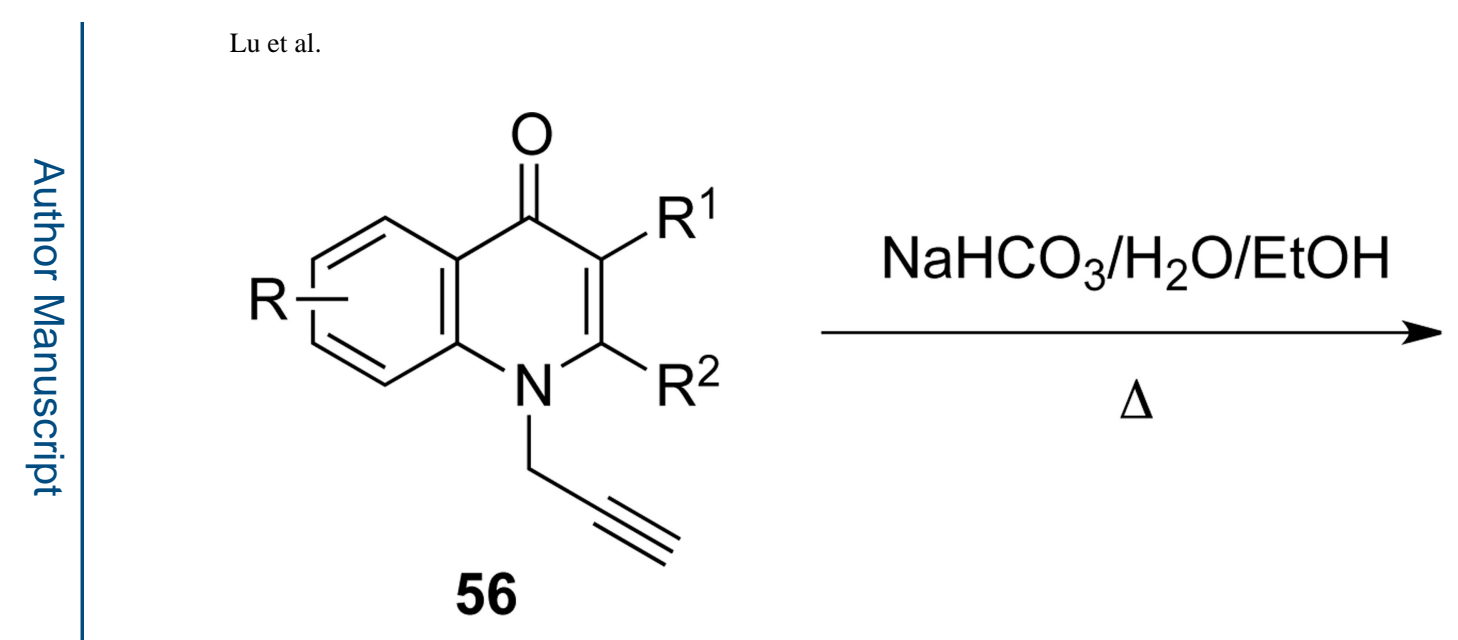<smiles></smiles>

57<smiles>C=C=Cn1c2ccccc2c(=O)c2ccccc21</smiles>

57c: $0 \%$ 


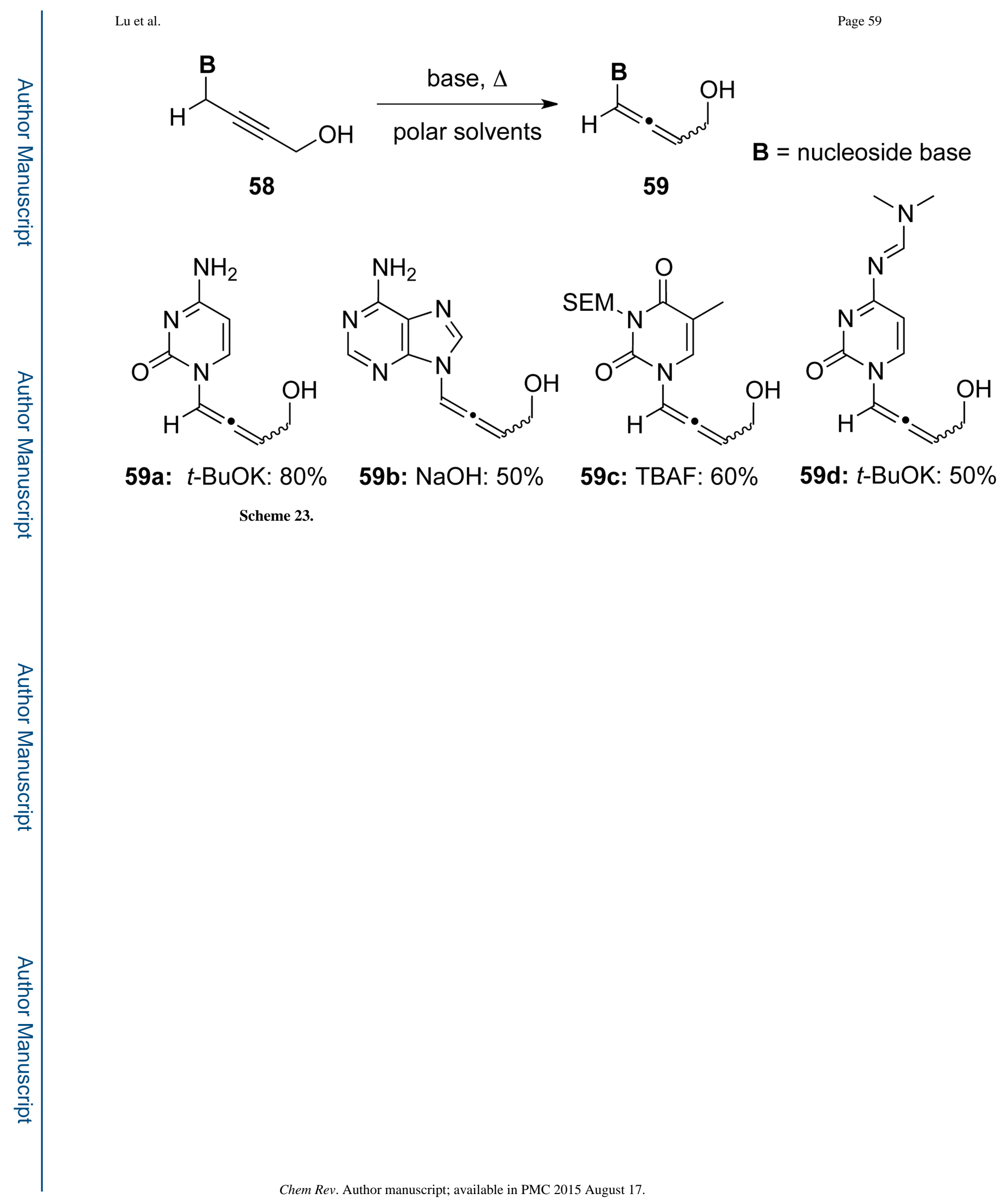




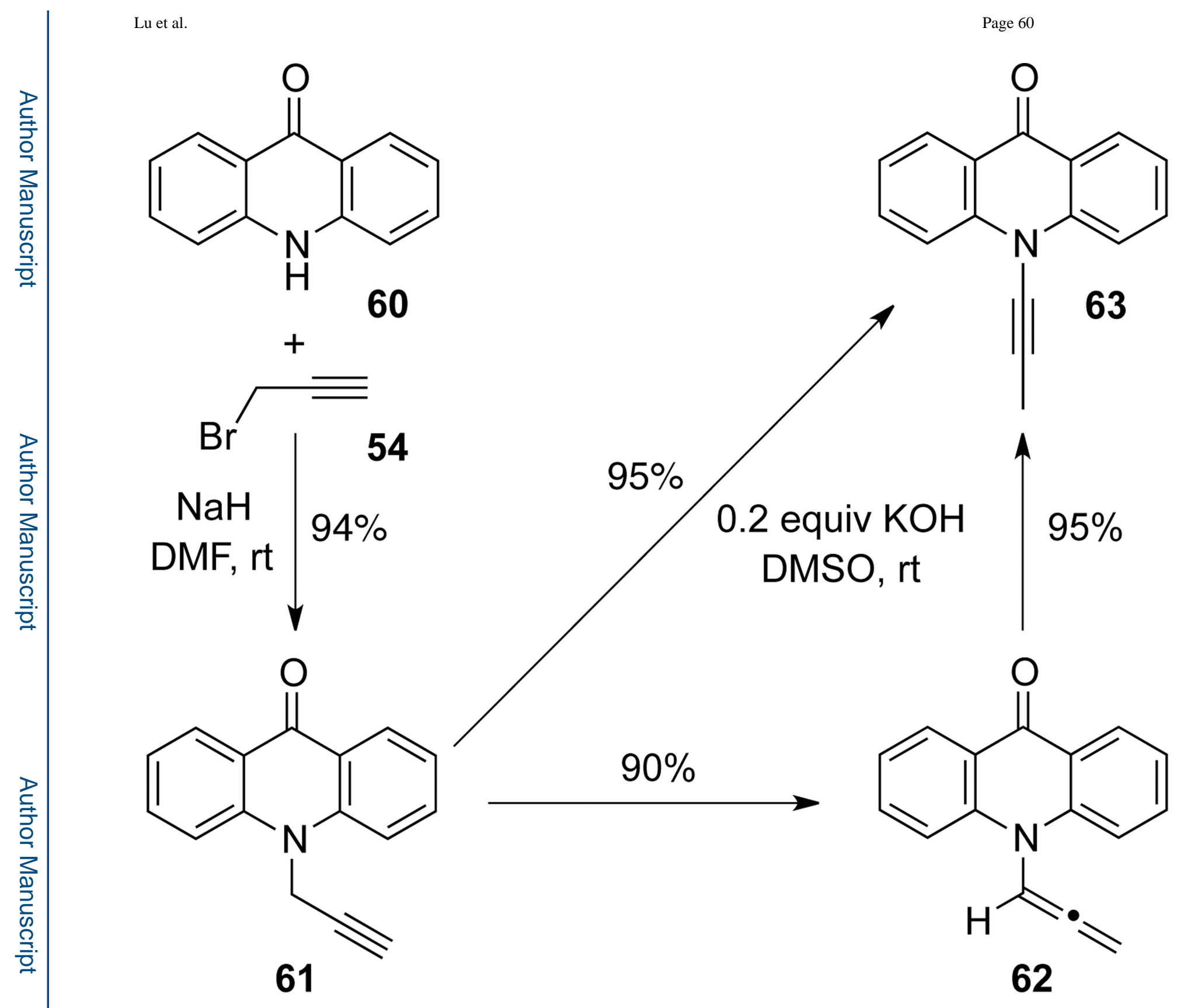

Scheme 24. 
<smiles>O=C1CCCN1</smiles>

64

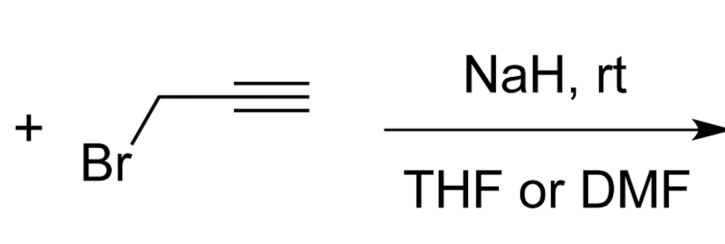

54<smiles>[X]C1=[Y]CCN1CC#C</smiles>

65

$$
0.2 \text { equiv } t \text {-BuOK, THF, rt }
$$

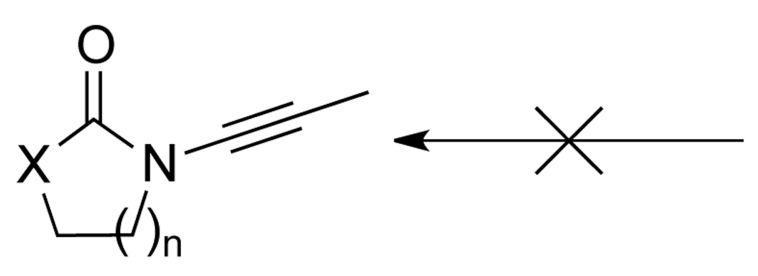

67: ynamides

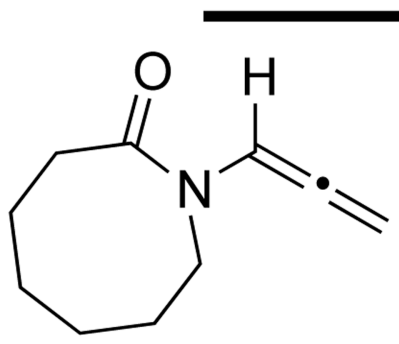

66b: $74 \%$<smiles>C=C=CN1C(=O)OC[C@H]1C(c1ccccc1)c1ccccc1</smiles>

$66 \mathrm{e}$<smiles>C=C=CN1C(=O)N(C)[C@H](C)[C@@H]1c1ccccc1</smiles>

$66 f$

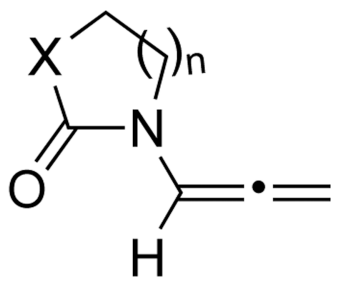

66

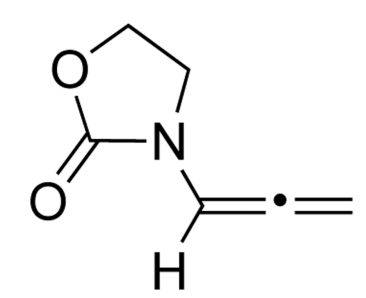

66c: $52 \%$<smiles>C=C=CN1C(=O)OC[C@H]1c1ccccc1</smiles>

$66 \mathrm{~g}$

Scheme 25.

$66 \mathrm{e}-66 \mathrm{~g}$

yield: $\geq 90 \%$ 
<smiles>[R]c1ccc2[nH]c3ccccc3c(=O)c2c1</smiles>

68<smiles>[R]c1cccc2c(=O)c3ccccc3n(CC#C)c12</smiles>

69: unable to isolate<smiles>[R]c1ccccc1-n1c2ccccc2c(=O)c2ccccc21</smiles>

70

PTC: cetyltrimethylammonium bromide<smiles>C=C=Cn1c2ccc(C(=C=C)n3c4ccc(C(=O)O)cc4c(=O)c4ccc(C)cc43)cc2c(=O)c2ccc(Cl)cc21</smiles>

70a: $70 \%$

70b: $81 \%$

70c: $79 \%$

Scheme 26. 


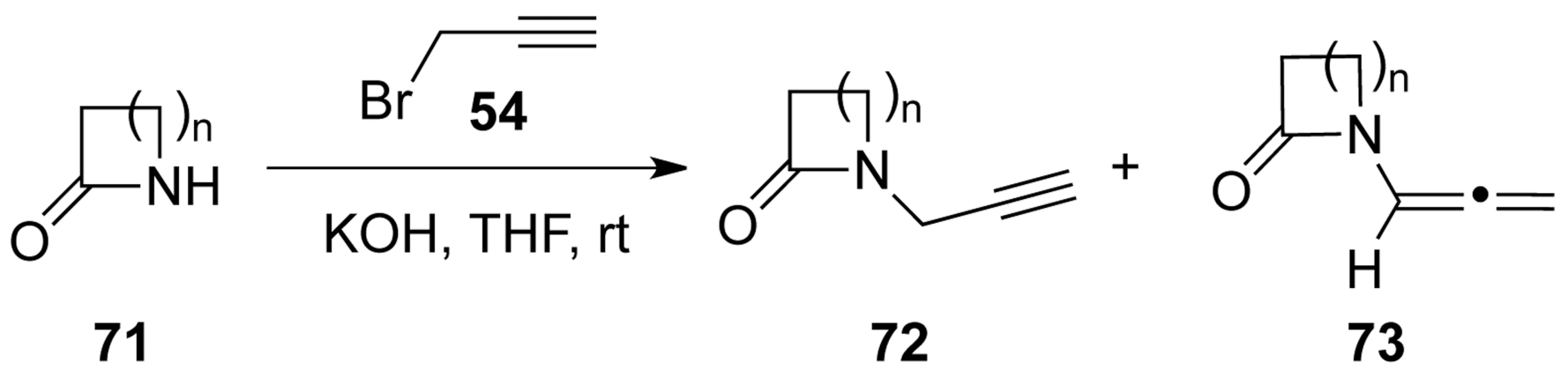

\begin{tabular}{ccc}
\hline $\mathrm{n}$ & yield [\%]: $72+\mathbf{7 3}$ & ratio: $\mathbf{7 2}: \mathbf{7 3}$ \\
\hline 1 & 37 & $0: 100$ \\
2 & 100 & $<1:>99$ \\
3 & 100 & $3: 2$ \\
4 & 91 & $12: 5$ \\
5 & 77 & $30: 1$
\end{tabular}

Scheme 27. 


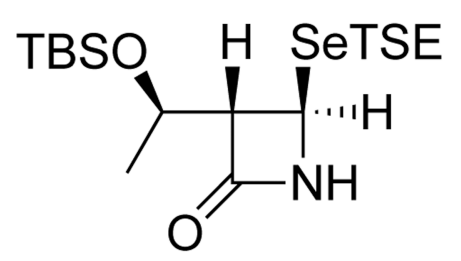

74

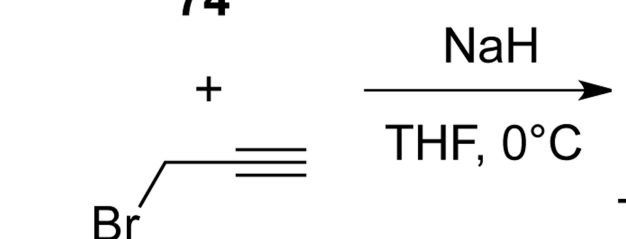

54

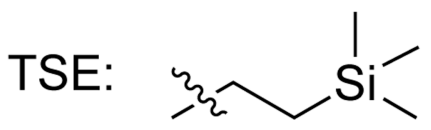

Scheme 28 .

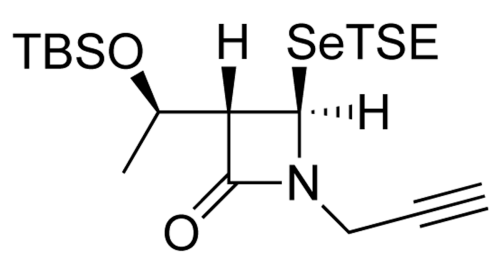

75: $52 \%$

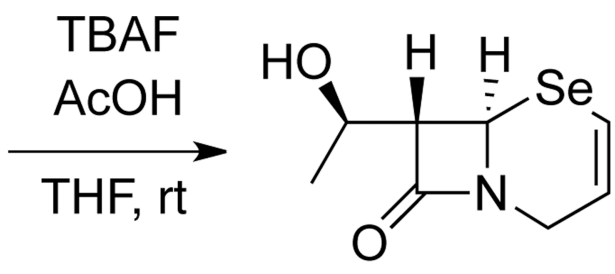

76: $78 \%$

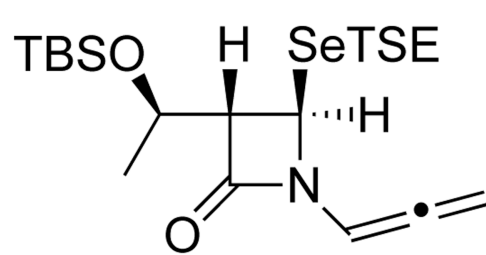

77: $12 \%$

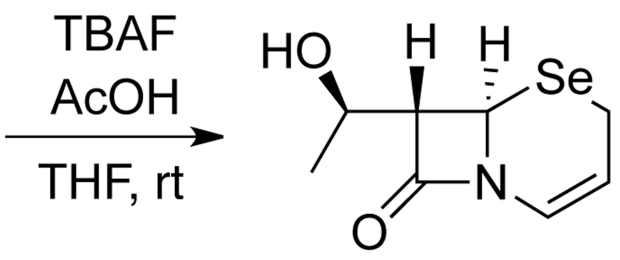

78: $55 \%$ 
Lu et al.

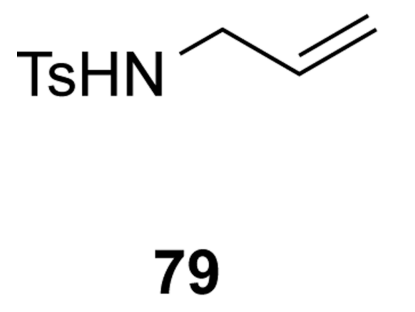

Scheme 29.
Page 65

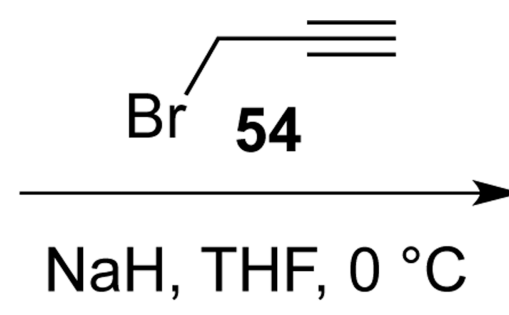

$\mathrm{H}$

80: $19 \%$

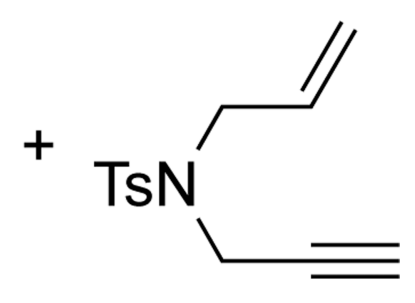

81: $49 \%$

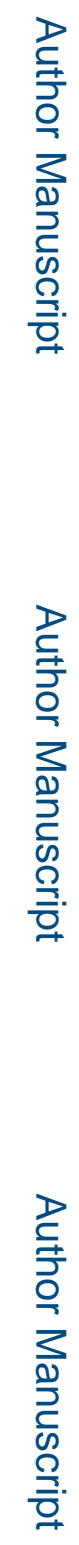




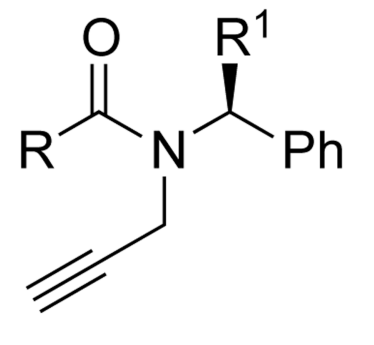

82

82a: $R=O B n, R^{1}=H$

82b: $R=O M e, R^{1}=M e$

82c: $R=M e, R^{1}=M e$

82d: $R=P h, R^{1}=M e$

Scheme 30.<smiles>[R]C(=O)N(C=C=C)[C@H]([R7])P</smiles>

83

$75 \%$

$60 \%$

not isolated

not isolated

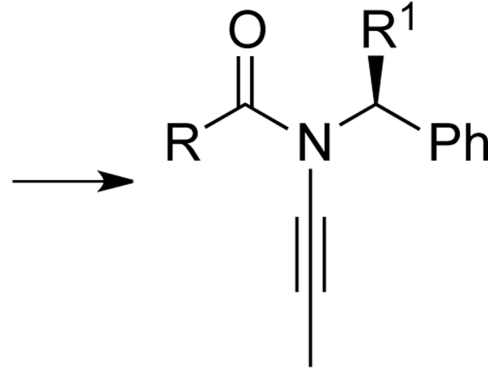

84

0

0

$83 \%$

$50 \%$ 


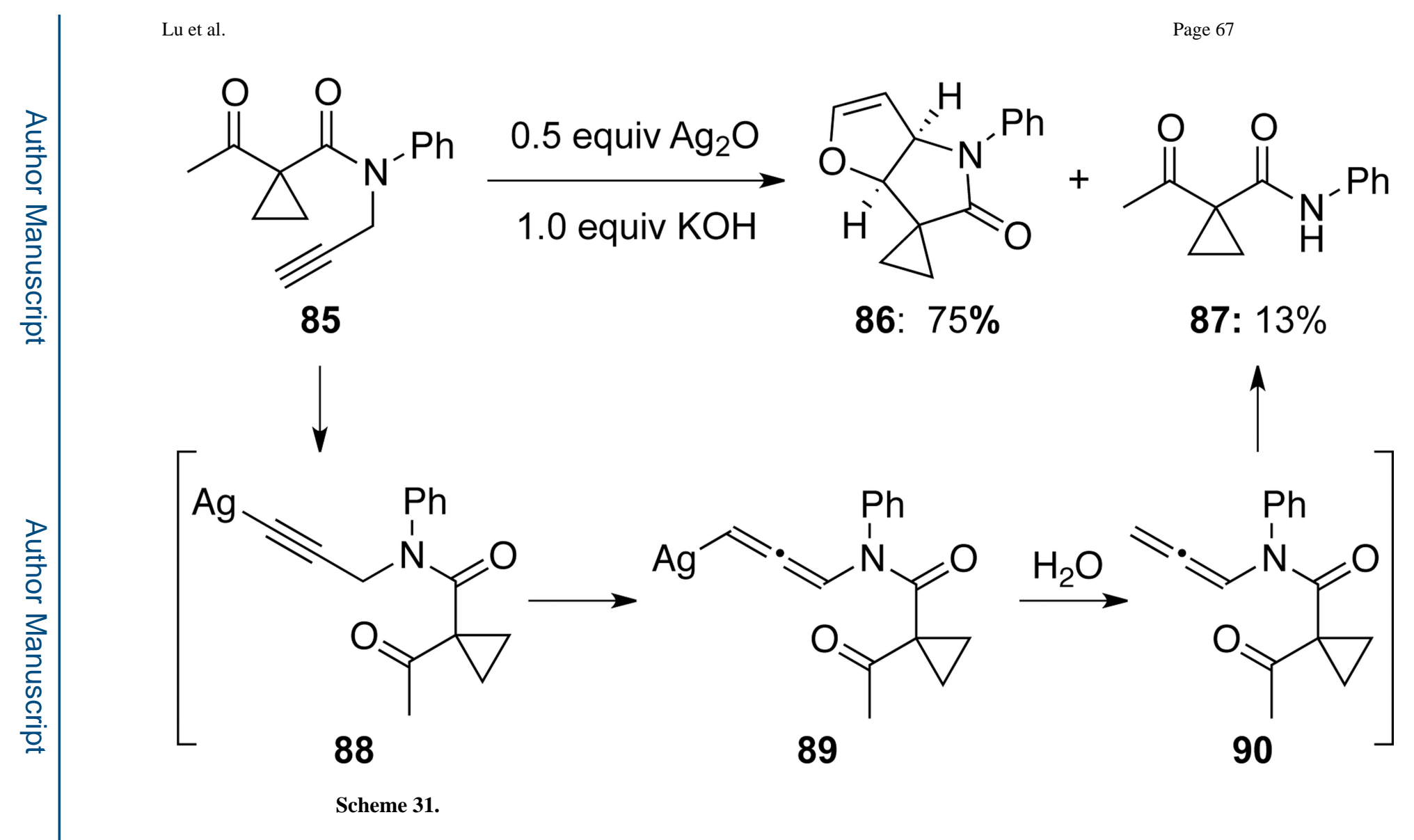


Lu et al.

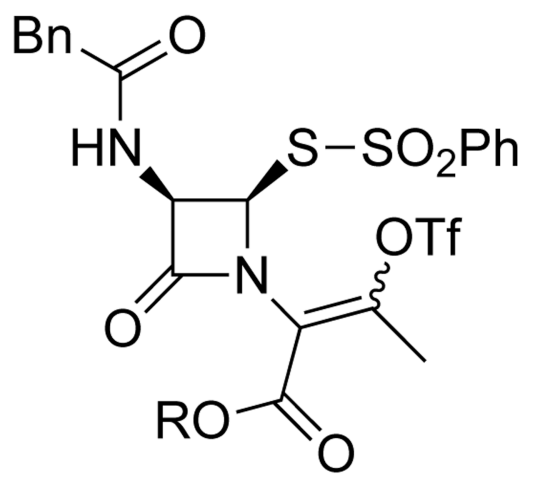

91
$\mathrm{R}=\mathrm{PMB}$ or $\mathrm{CHPh}_{2}$

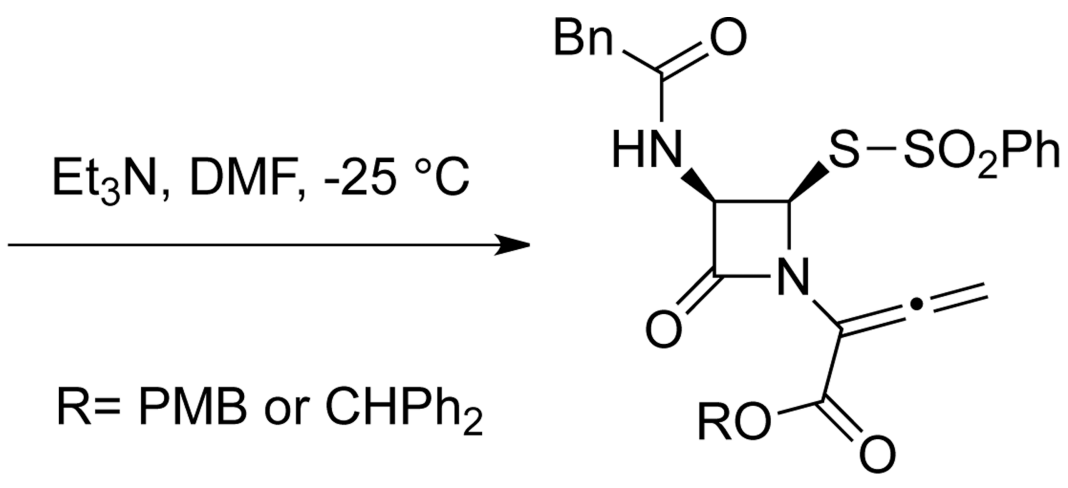

92: $98 \%$<smiles>NC(=O)CO[Pb]</smiles>

$\mathrm{HN}$<smiles>[R6]OC(=O)C(=C(C)[O-])N1C(=O)[C@@H](N)[C@H]1[As]</smiles>

$\mathrm{Et}_{3} \mathrm{~N}, \mathrm{rt}, \mathrm{THF}$ or $\mathrm{CH}_{2} \mathrm{Cl}_{2}$<smiles>CC(=O)CO[Pb]</smiles>

93

$\mathrm{R}=\mathrm{PNB}[p$-nitrobenzene $]$ or $\mathrm{CHPh}_{2}$

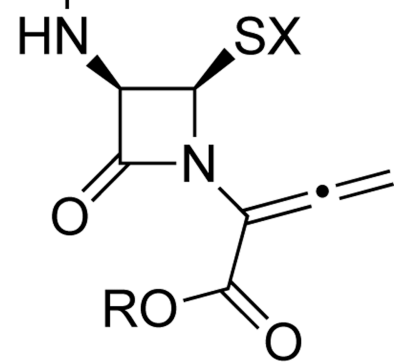

94: $100 \%$<smiles>[Y][Z9]([H])Sc1nc2ccccc2s1</smiles>

Scheme 32. 


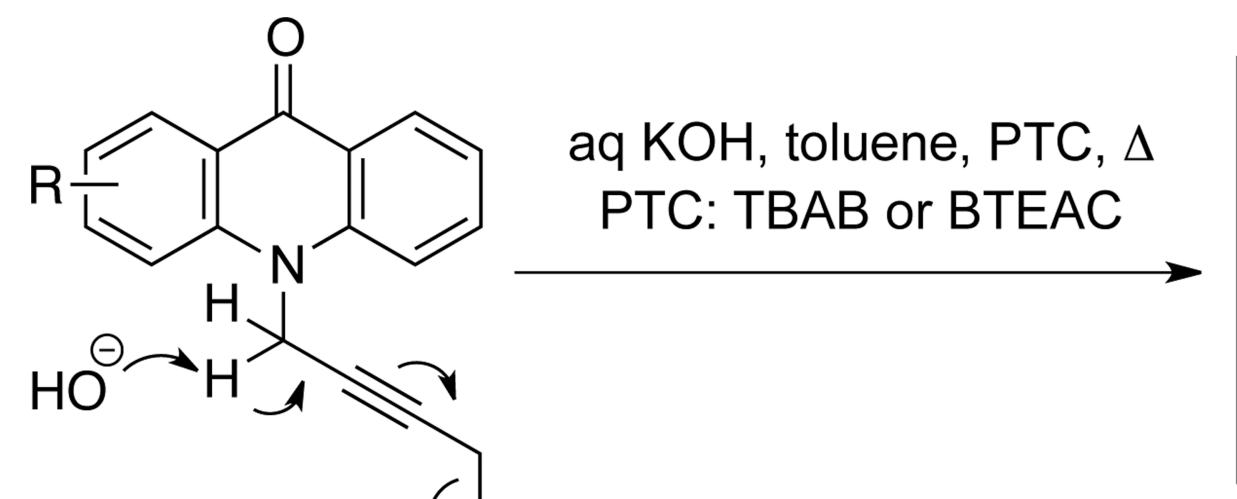

$95 \oiiint$ OAc<smiles>C=C=C(CO)C(CO)n1c2c[R]ccc2c(=O)c2ccccc21</smiles>

96

$\mathrm{R}=\mathrm{H}, \mathrm{Cl}$ or $\mathrm{Me}$ $68 \%-72 \%$

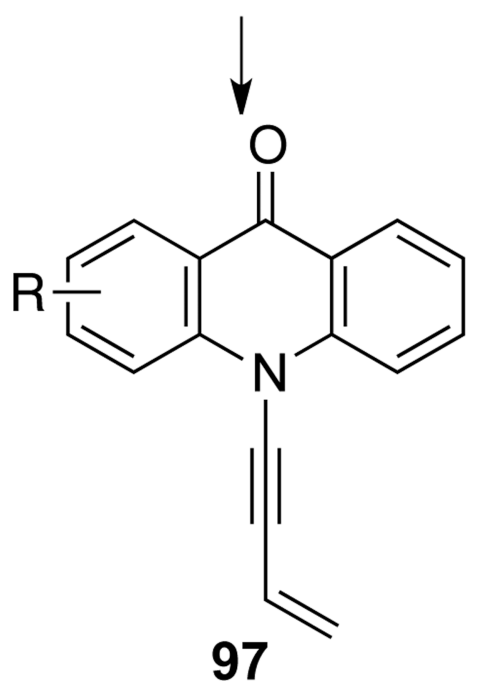

Scheme 33. 


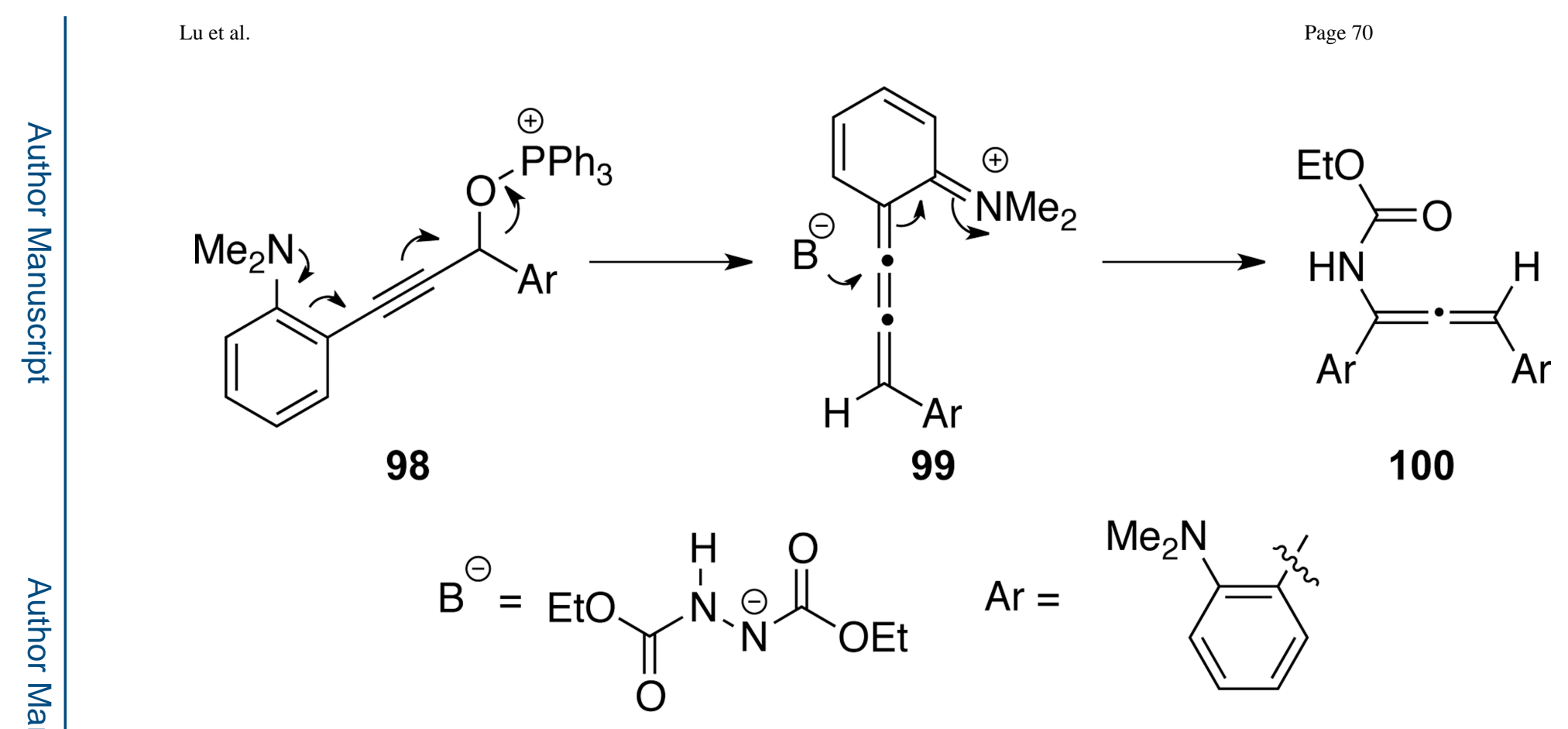

Scheme 34. 

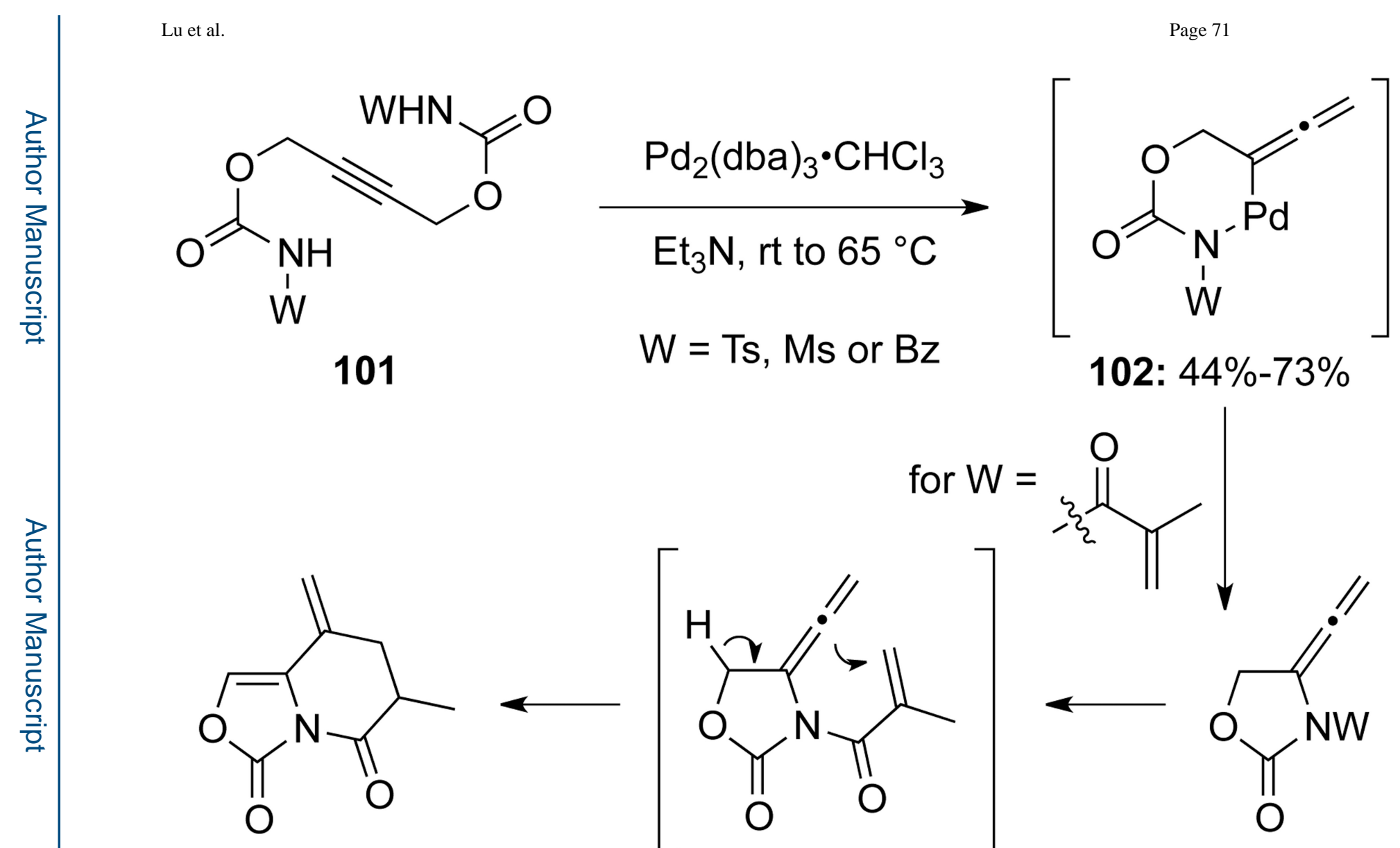

105: $33 \%$
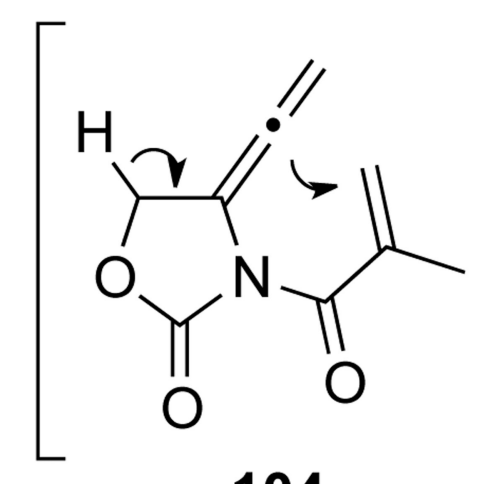

104<smiles>C=C(C)C(=O)C(C)C(C)=NO</smiles>

Scheme 35. 
<smiles>[R]C([R])(C#CCOC(=O)N[As])OC(=O)N[AsH3]</smiles><smiles>CCNC(=O)C(C)C(C)C(=O)O</smiles><smiles>[R]C1([R])OC(=O)N([S+])C1=C=C</smiles><smiles>[R]C([R])=C=C1COC(=O)[NH+]1[SH3+]</smiles>

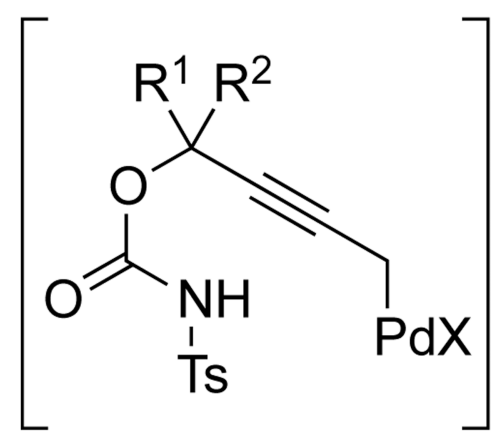

109
O 108

\section{$\mathrm{R}$}

$\mathrm{R}^{2} \quad$ yield [\%]: $107+108$

ratio: $107: 108$

\begin{tabular}{llll}
\hline Et & $\mathrm{H}$ & 47 & $1.7: 1$ \\
$t-\mathrm{Bu}$ & $\mathrm{H}$ & 58 & $2.0: 1$ \\
$\mathrm{Ph}$ & $\mathrm{H}$ & 58 & $2.1: 1$ \\
$\mathrm{Me}$ & $\mathrm{Me}$ & 70 & $30: 1$ \\
$-\left(\mathrm{CH}_{2}\right)_{5^{-}}$ & 56 & $20: 1$ \\
\hline
\end{tabular}

Scheme 36. 


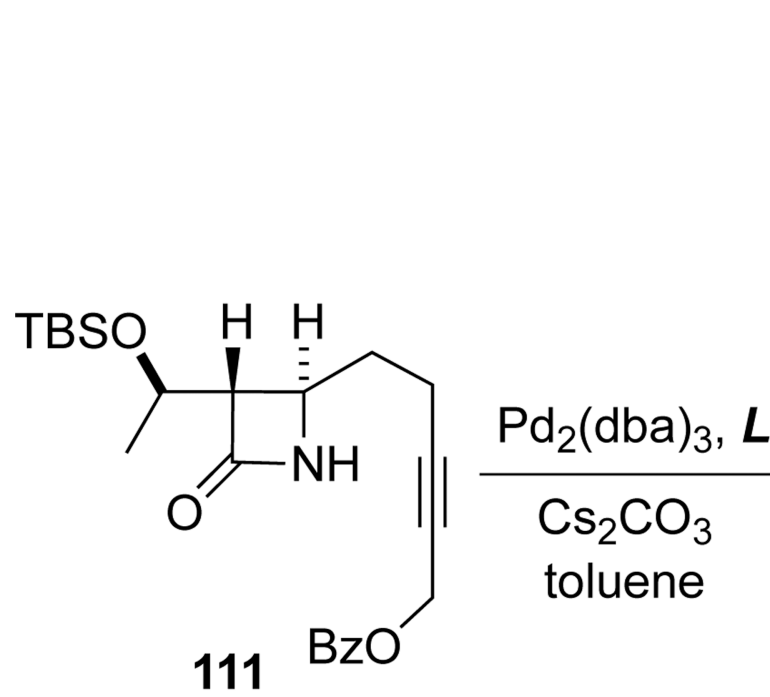

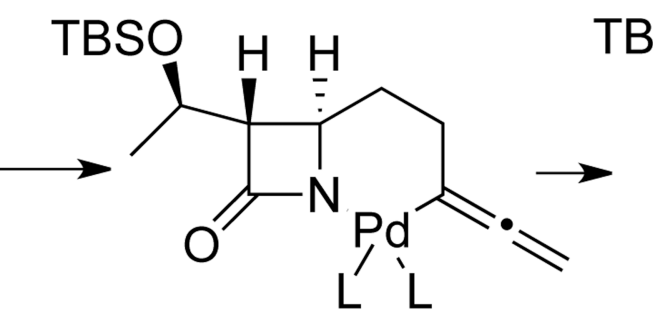

$L=\mathrm{P}(\text { o-tolyl })_{3}, 112$

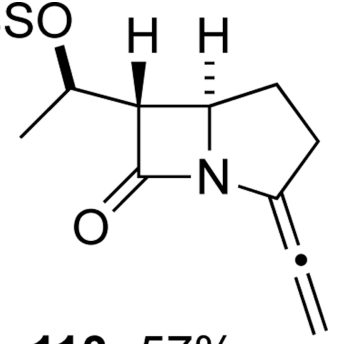

113: $57 \%$ 111

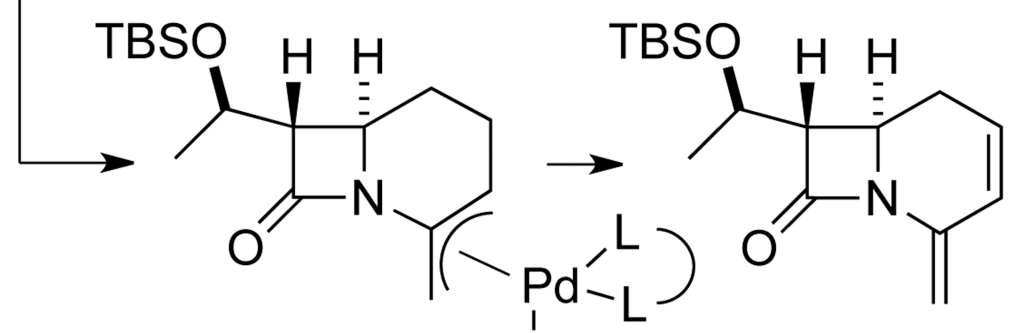

$$
L=\text { dppf, } 114
$$

115: $56 \%$ 


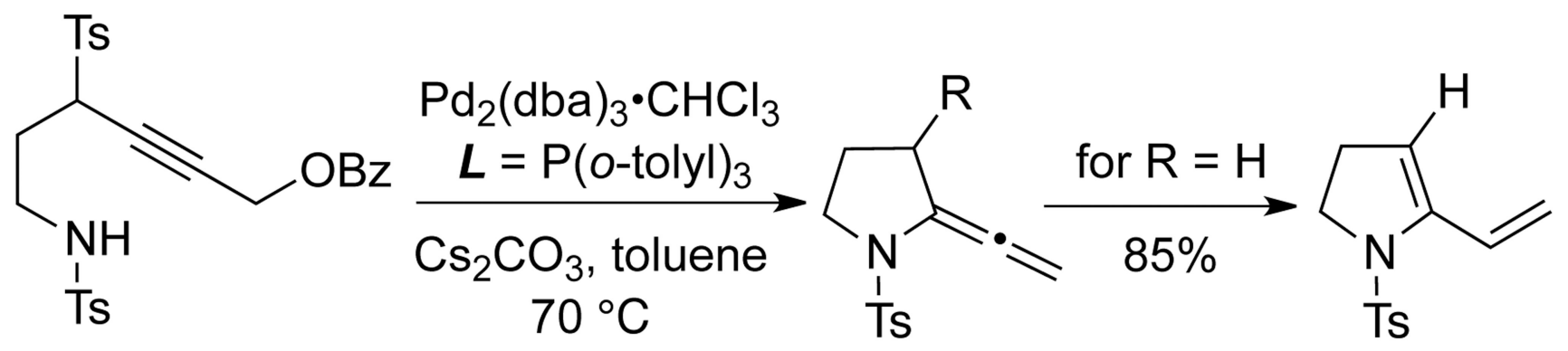

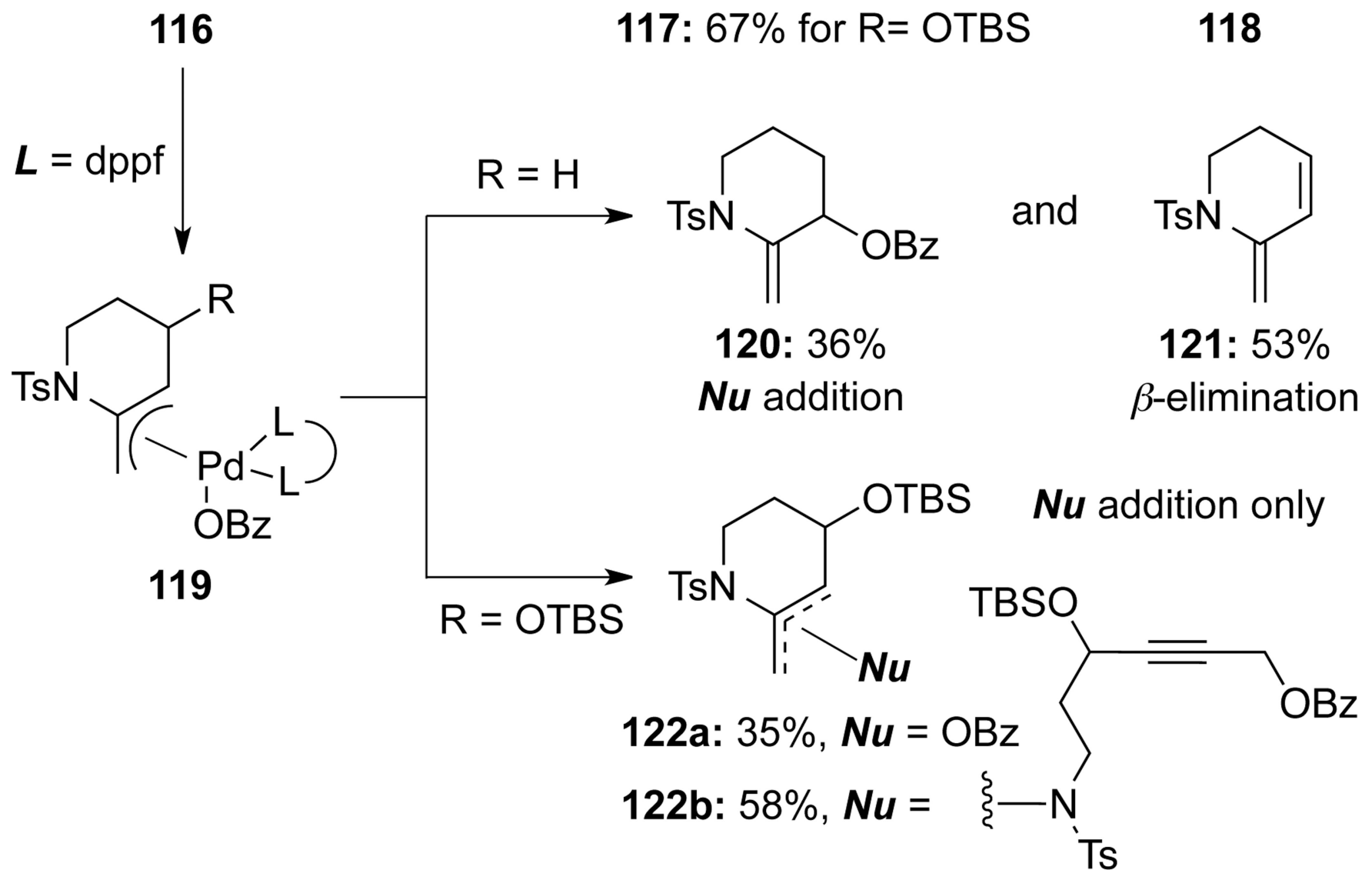

Scheme 38 . 


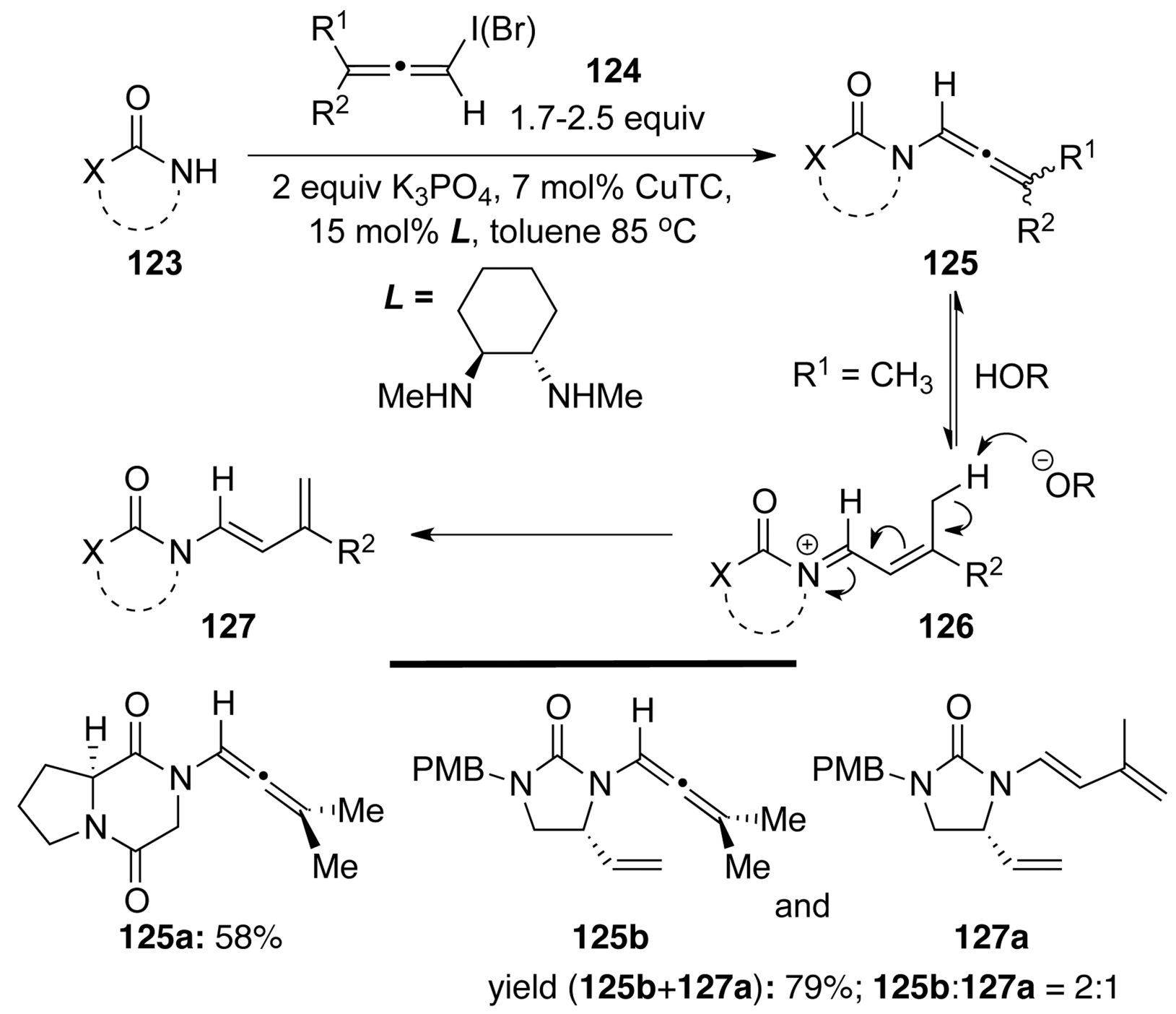<smiles>O=C1OCCN1C=C=CPBr</smiles>

125c: $100 \%$<smiles>CC(C)=C=CN(C)C(=O)c1ccccc1C</smiles>

125d: $20 \%$<smiles>C=C(C)/C=C/NC(=O)c1ccccc1</smiles>

127b: $47 \%$ 

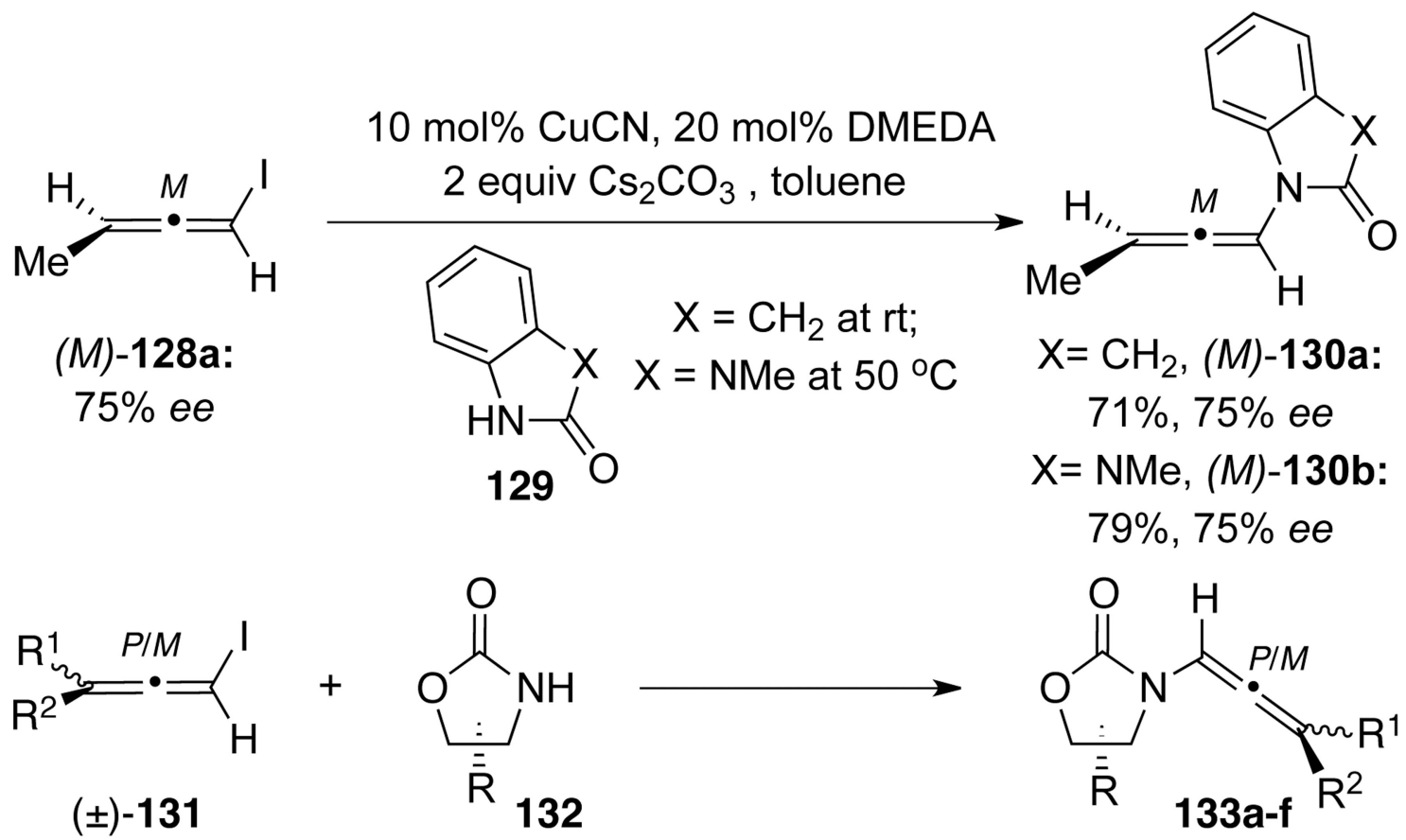<smiles>O=C1OCC(Br)N1C=C=C1CCCCC1</smiles>

(R)-133a: $41 \%$<smiles>[Y10]C(C)=C=CN1C(=O)OCC1Br</smiles>

$133 \mathrm{~d}(P, R) \&(M, R): 84 \%$

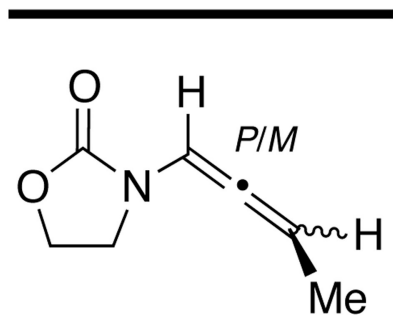

(土)-133b: $90 \%$<smiles>CC(C)=C=CN1C(=O)OC[C@H]1CCc1ccco1</smiles>

$133 \mathrm{e}(P, R) \&(M, R): 55 \%$<smiles>[14CH3]C([14CH3])=C=CN(Cc1ccccc1)S(=O)(=O)[O-]</smiles>

(土)-130c: $60 \%$<smiles>[2H]C([14CH3])=C=CN1C[C@H](CC=C)COC1=O</smiles>

$133 f(P, R) \&(M, R): 35 \%$

Scheme 40. 
$15 \mathrm{~mol} \%$ CuTC, 30mol\% DMEDA.

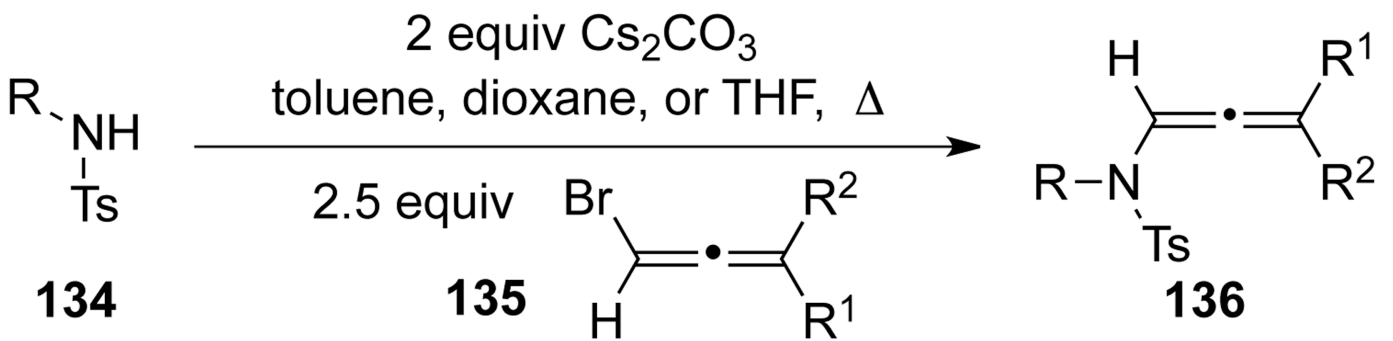<smiles>CC(C)=C=CN([As])c1ccccc1</smiles>

136a: $56 \%$<smiles>[3H]N(C=C=CC)CC=C</smiles>

136b:35\%<smiles>CC(C)=C=CN([As])CC=Cc1ccc(C(F)(F)F)cc1</smiles>

136c: $52 \%$

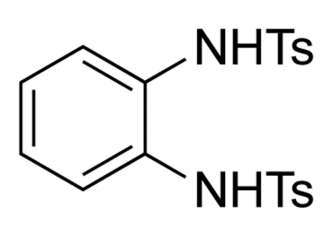

137

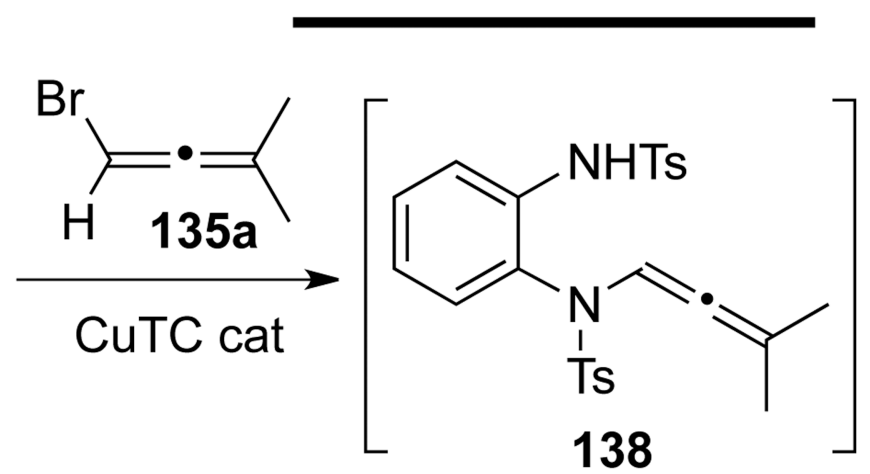

138<smiles>CC(C)=CC1N([As])c2ccccc2N1[AsH3]</smiles>

139: $63 \%$

Scheme 41. 


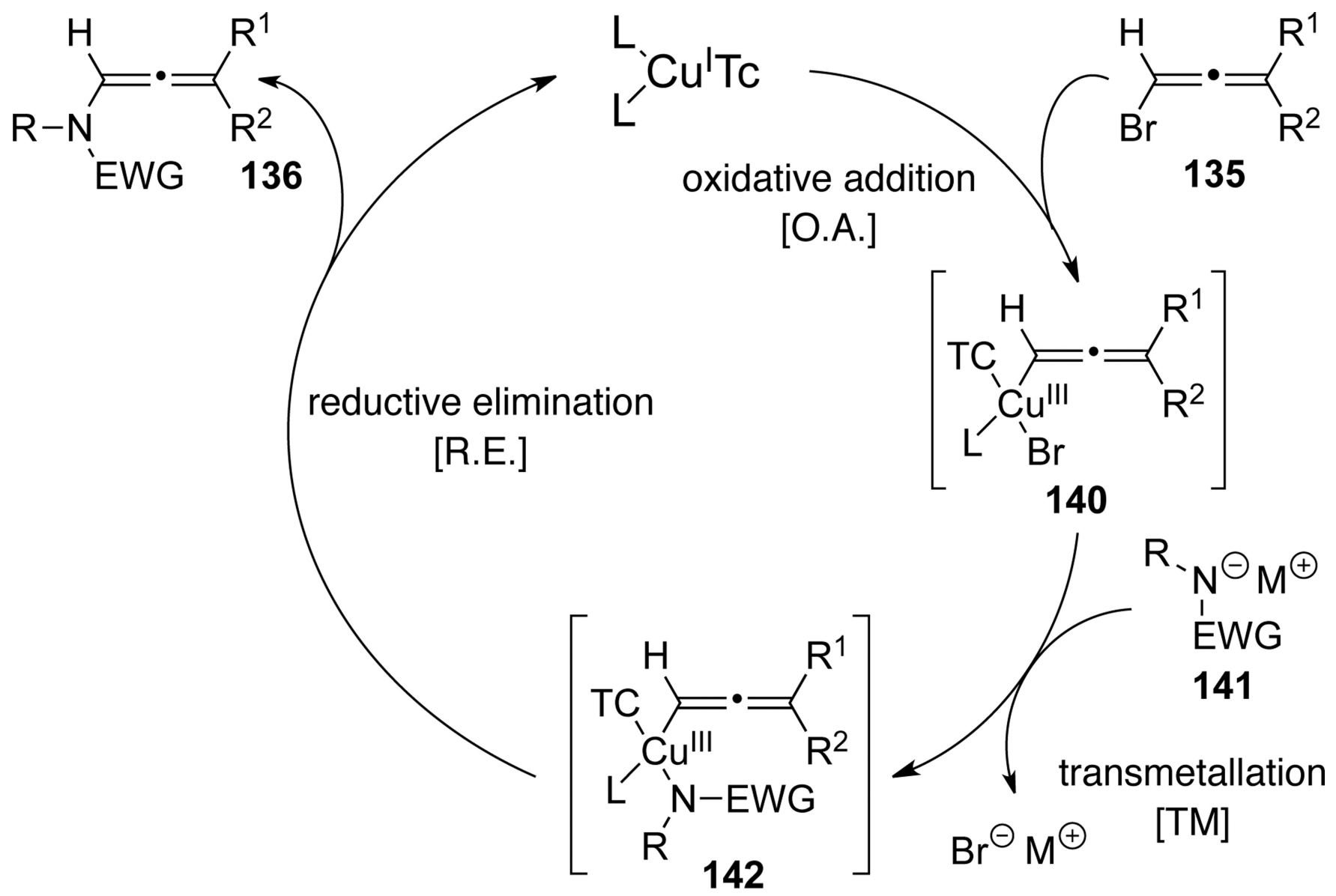

Scheme 42. 


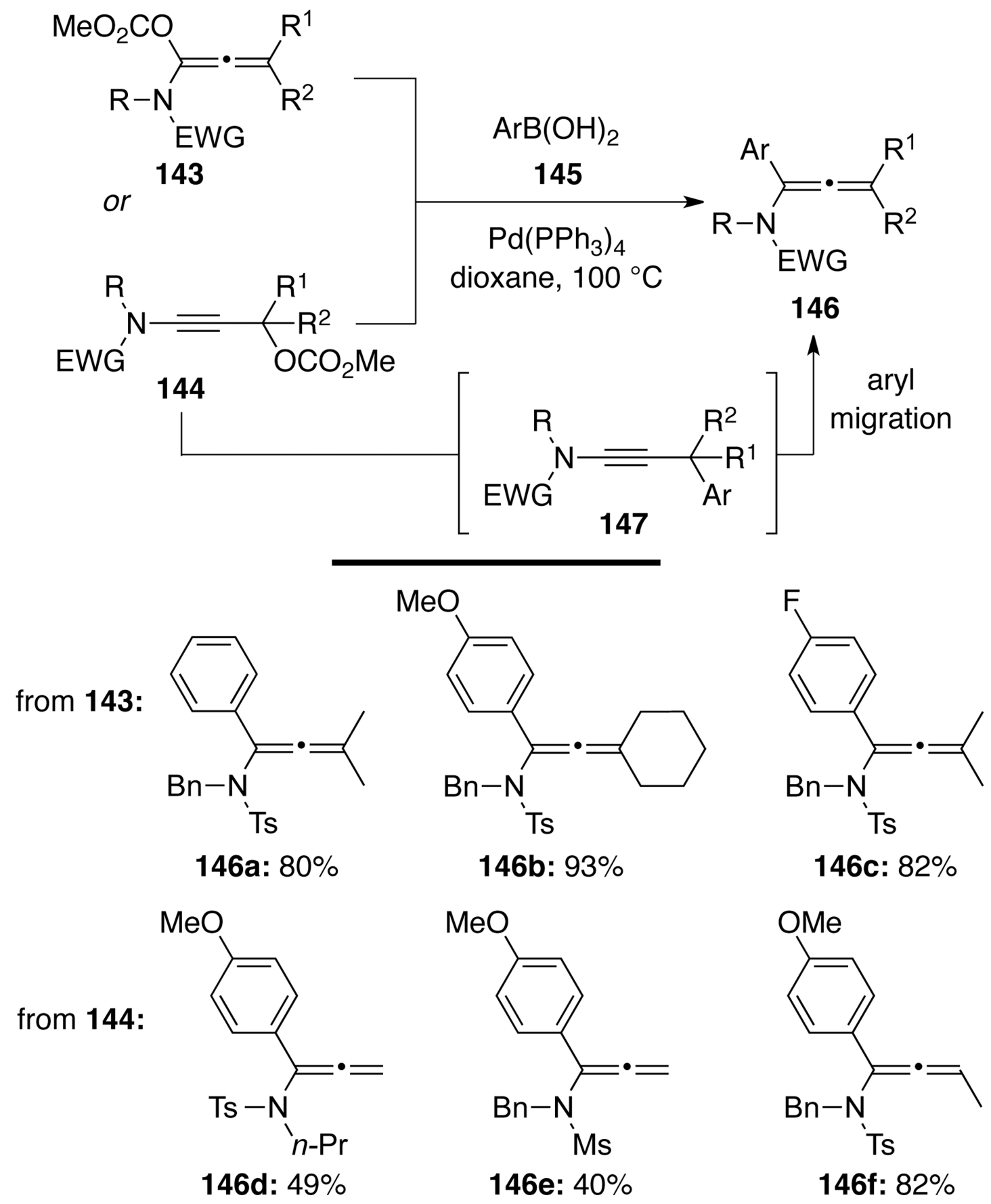

Scheme 43. 


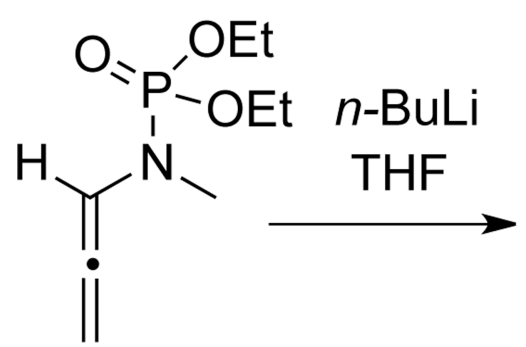

148

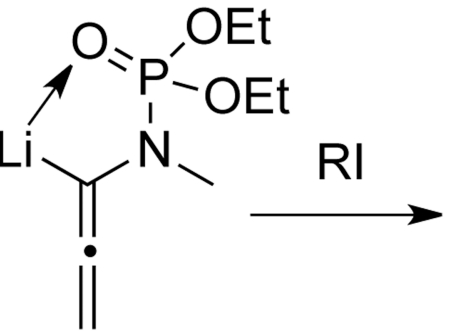

149<smiles>CCOP(C)(=O)OCC</smiles><smiles>[R]C(=O)C=CC(=O)N(C)C(C)Cl</smiles>

150
151

$$
\mathrm{R}=\mathrm{Me} \text { or } \mathrm{Bn}
$$

Scheme 44. 


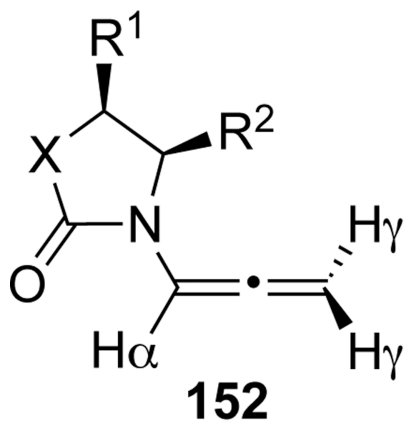

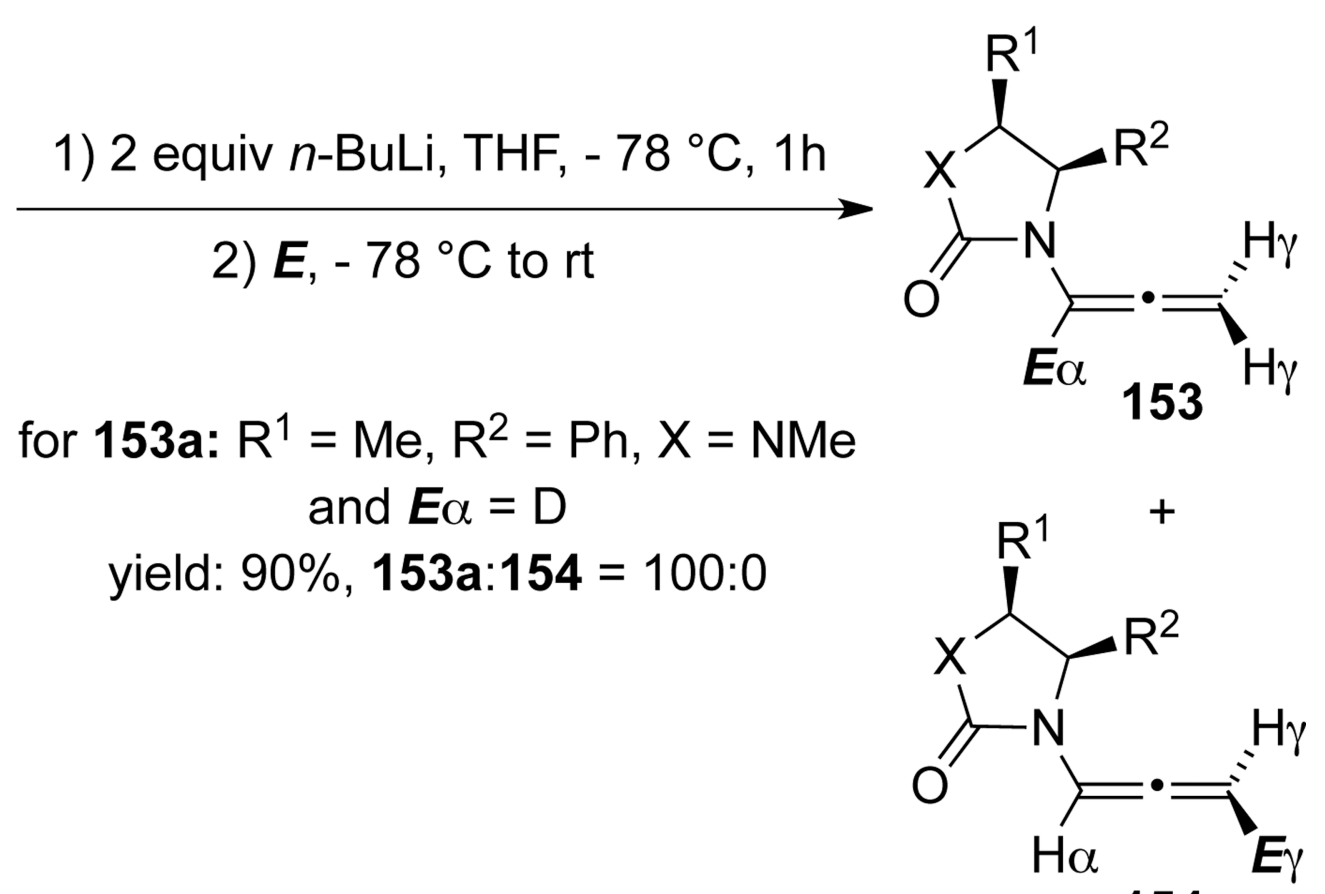

154

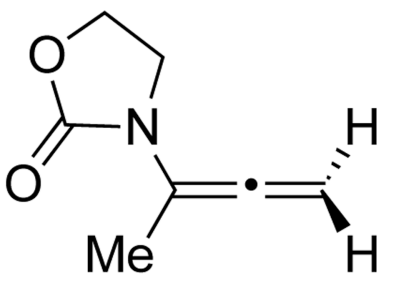

153b: $84 \%$<smiles>C=C=C([SeH])N1CCOC1=O</smiles>

153c: $92 \%$<smiles>C=C=C(SC)N1C(=O)OC[C@H]1P</smiles>

153d: $73 \%$ 


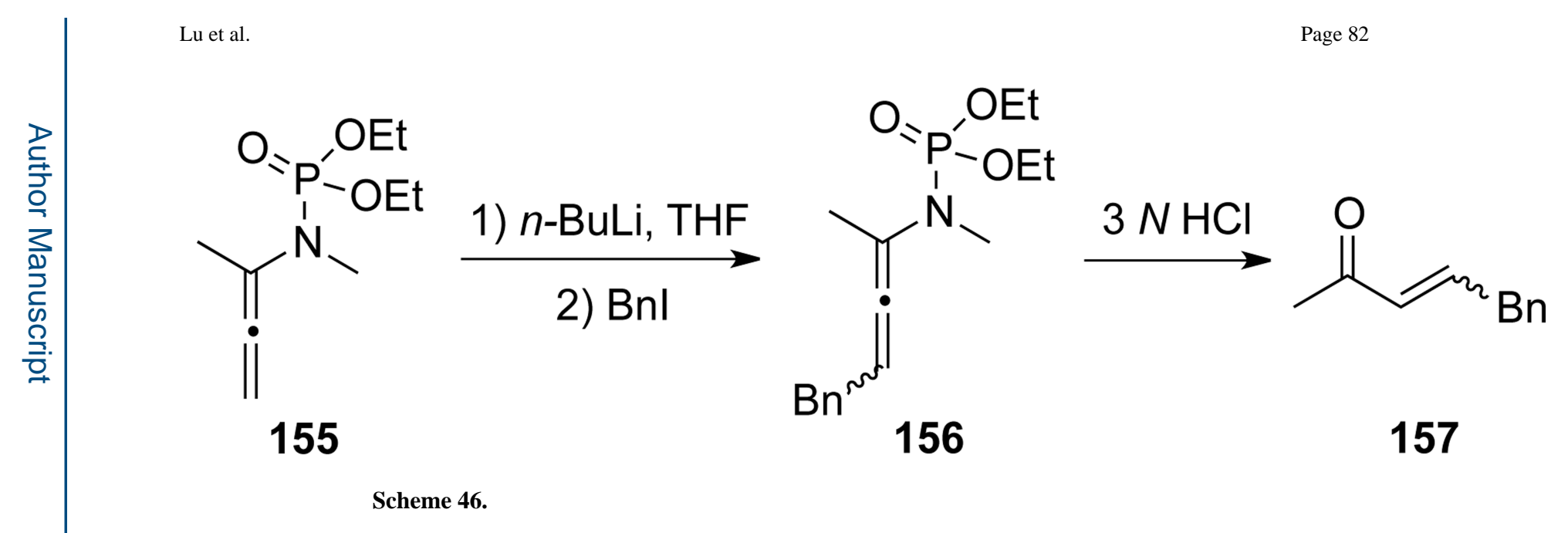


<smiles>[CH]C(=C=C[TlH2])N1C(=O)N(C)[C@@H](C)[C@@H]1c1ccccc1</smiles>

1) 1 equiv $t$-BuLi, THF, $-78^{\circ} \mathrm{C}, 1 \mathrm{~h}$

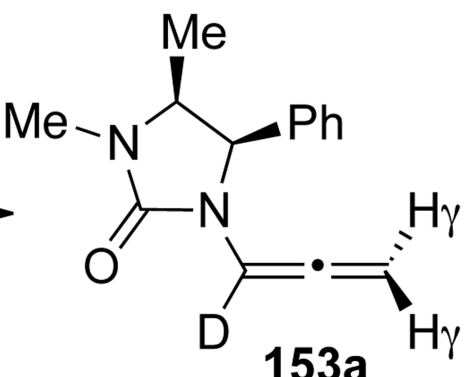
2) $\mathrm{D}_{2} \mathrm{O},-78^{\circ} \mathrm{C}$ to $\mathrm{rt}$ $76 \%, 153 a: 154 a=50: 50$<smiles>[2H]C=C=C([2H])N1C(=O)N(C)[C@H](C)[C@@H]1c1ccccc1</smiles>

$154 a$<smiles></smiles>

1) 2 equiv $n$-BuLi ,THF, $-78{ }^{\circ} \mathrm{C}, 1 \mathrm{~h}$<smiles>[2H]C=C=C(C)N1C(=O)OC[C@H]1c1ccccc1</smiles>

158 159: $60 \%, d r 2: 1$

Scheme 47. 


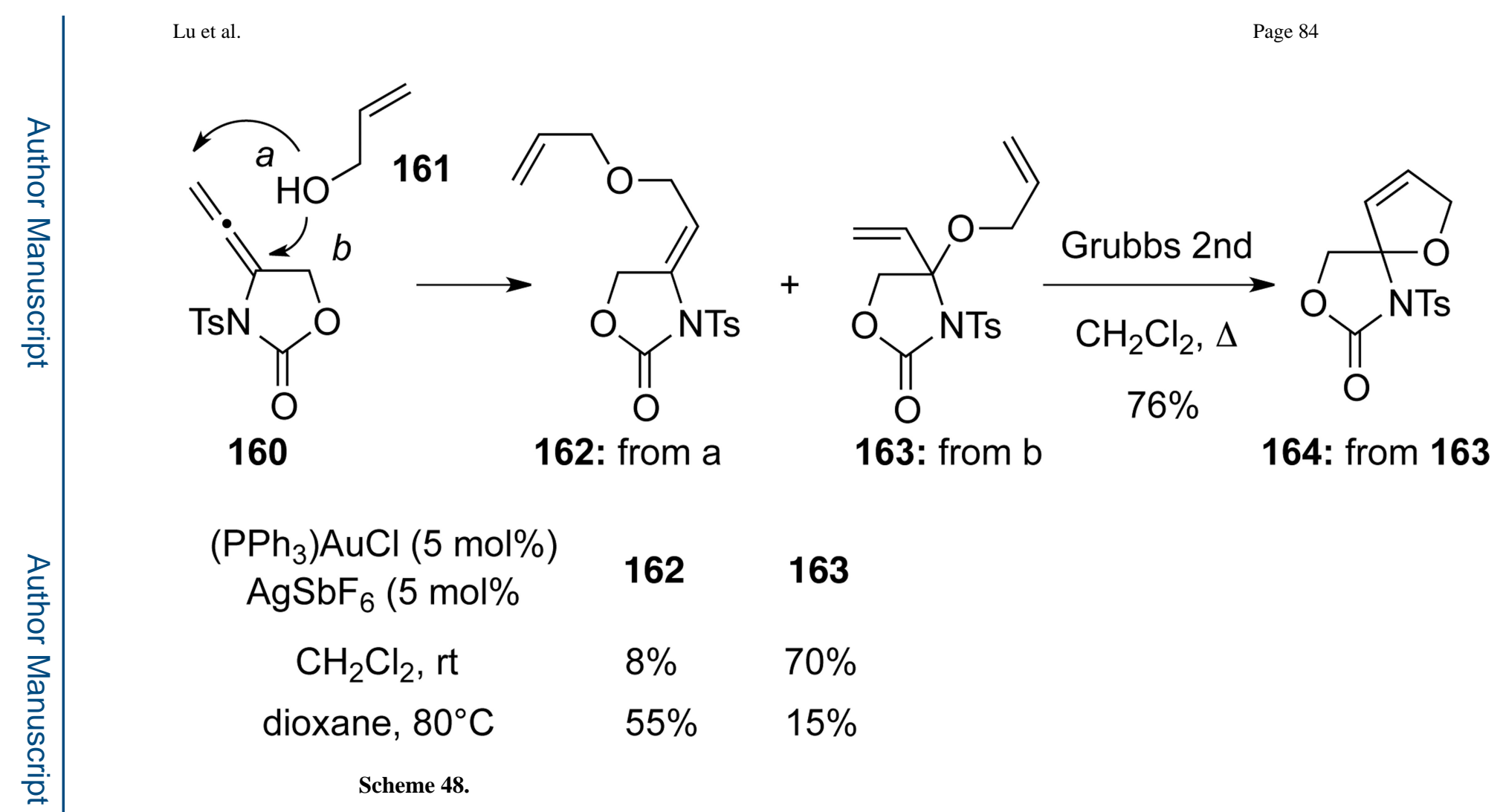




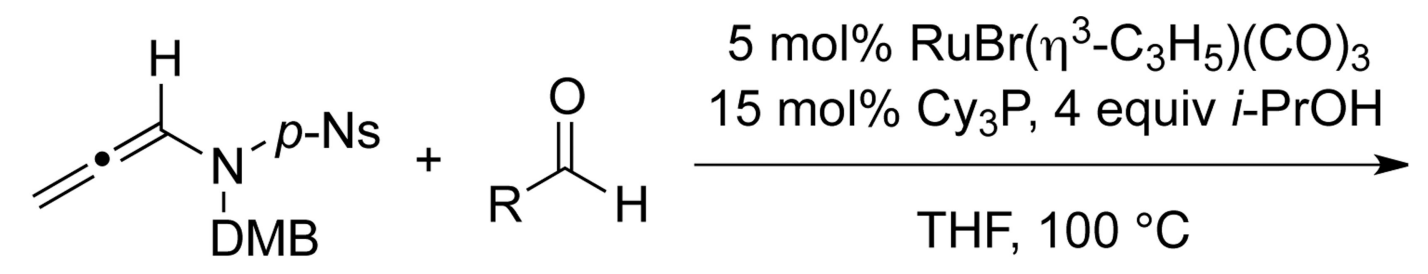

165

\section{6}

$\mathrm{R}=$ aryl, akyl or allyl, $d r>20: 1$<smiles>[R]C(O)[C@H](C=C)N([R19])[N+](=O)[O-]</smiles>

167<smiles>[R20]C1=CCC[R19]([R6])(C)C1</smiles>

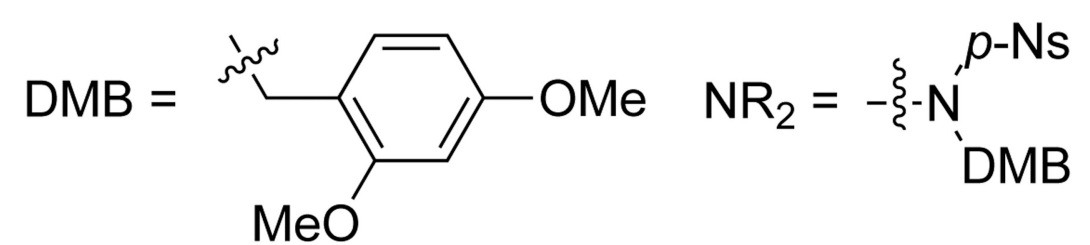<smiles>[R20][C@H](C=C)[C@@H](O)c1ccccc1</smiles>

167a: $70 \%$<smiles>[R20][C@H](C=C)[C@@H](O)/C=C/C</smiles>

167d: $63 \%$<smiles>[R20][C@H](C=C)[C@@H](O)c1ccc(Br)o1</smiles>

167b: $90 \%$<smiles>[R20][C@H](C=C)[C@@H](O)/C=C/COCc1ccccc1</smiles>

167e: $65 \%$<smiles>[R20][C@H](C=C)[C@@H](O)CN1C(=O)c2ccccc2C1=O</smiles>

167c: $85 \%$<smiles>[R20][C@H](C=C)[C@@H](O)/C=C/c1ccccc1</smiles>

167f: $61 \%$ 
<smiles>[R16]ON(C=C=C)O[SH3+]</smiles>

165

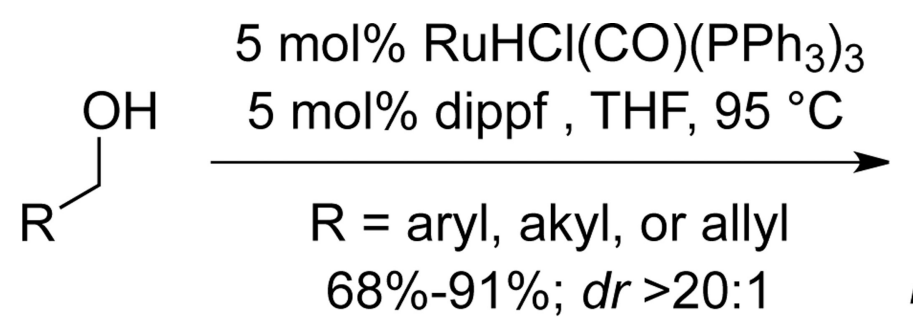

169

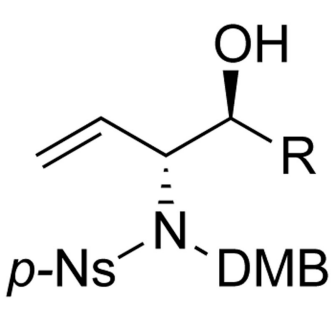

167

"redox" pair<smiles>C1CCCC1</smiles>

$\mathrm{H}^{\oplus}$
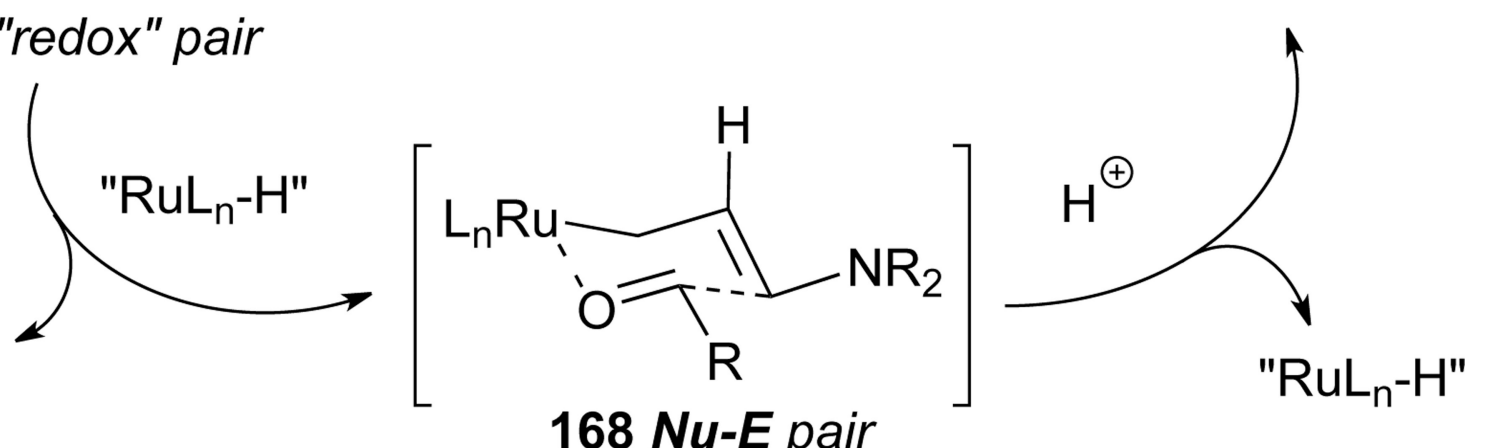

168 Nu-E pair<smiles>[R20][C@H](C=C)[C@@H](O)c1ccco1</smiles>

167g: $89 \%$<smiles>[R20][C@H](C=C)[C@@H](O)CC</smiles>

167j: $68 \%$

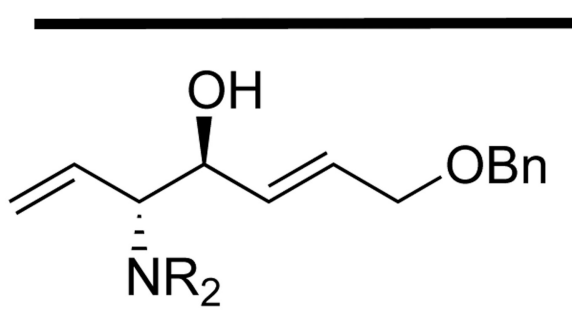

167h: $81 \%$<smiles>[R20][C@H](C=C)[C@@H](O)c1ccc(Br)cc1</smiles>

167k: $73 \%$<smiles>[R20][C@H](C=C)[C@@H](O)/C=C/c1ccccc1</smiles>

167i: $85 \%$<smiles>C=C[C@H]([NH2+])[C@@H](O)c1ccc(C(C)=O)cc1</smiles>

Scheme 50. 


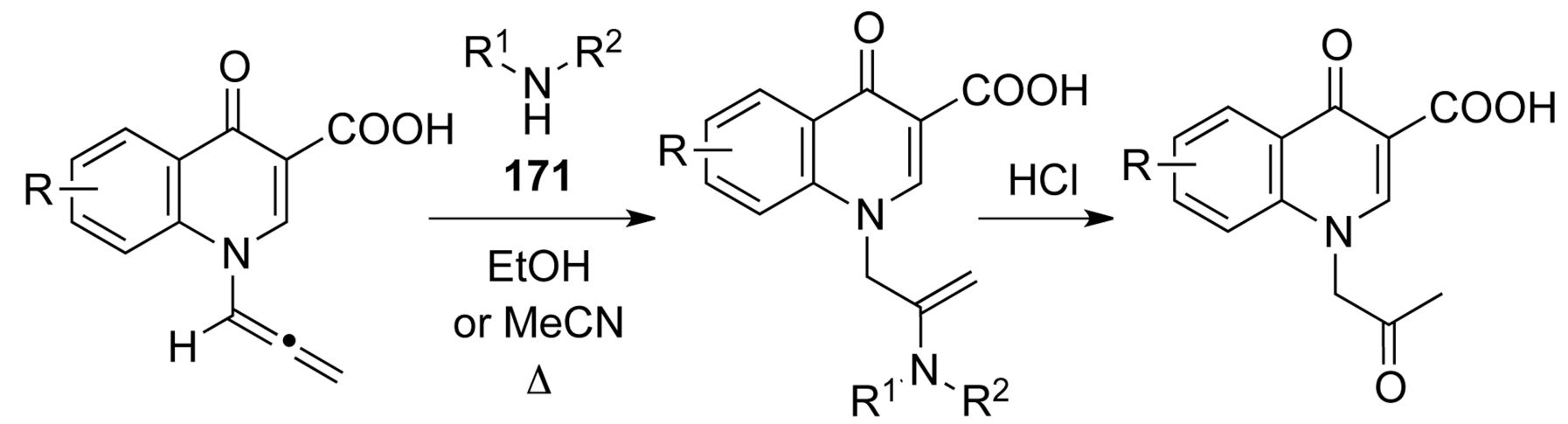

170

172: not isolated

173<smiles>CC(=O)Cn1cc(C(=O)O)c(=O)c2cc(F)c(Cl)cc21</smiles>

173a: $67 \%$<smiles>CC(=O)Cn1cc(C(=O)O)c(=O)c2cc3c(cc21)OCO3</smiles>

173b: $60 \%$

Scheme 51. 
<smiles>[R]C(=O)N[C@H]([R5])C(=O)N(C)C=C=C</smiles>

174
175

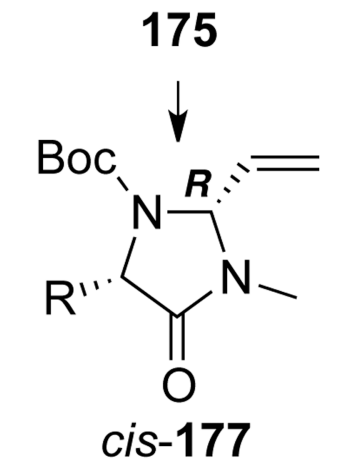

176

for $\mathrm{R}=i-\mathrm{Pr}, \mathrm{Me}, \mathrm{Et}, t-\mathrm{Bu}$ or $\mathrm{Ph}$ (cis + trans): $32 \%-62 \%$

for $\mathrm{R}=\mathrm{Bn}$, cis only: $65 \%$

Scheme 52. 


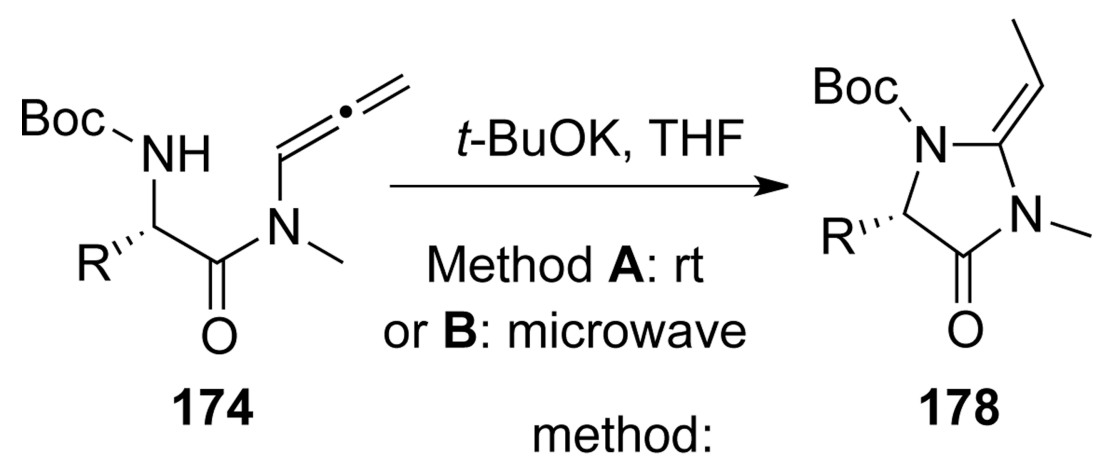<smiles>[R]C1C(=O)N(C)C=C(C)N1C(=O)O</smiles>

179

$29 \%$

$95 \%$

b: $\mathrm{R}=i-\mathrm{Pr}$

c: $R=t-B u$

$\mathrm{d}: \mathrm{R}=t-\mathrm{Bu}$

e: $R=B n$

f: $R=B n$

g: $\mathrm{R}=\mathrm{Ph}$

$32 \%$

0

A

$9 \%$

$28 \%$

B

0

A

$8 \%$

$89 \%$

$36 \%$

B

0

$72 \%$

$25 \%$

0

$27 \%$

0

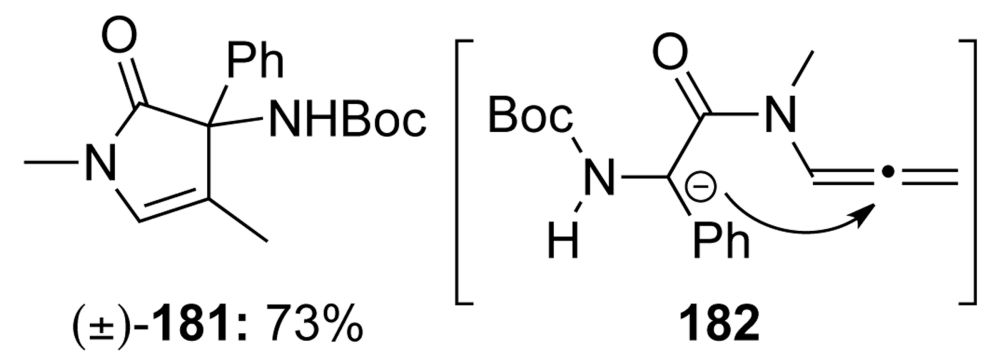

Scheme 53. 

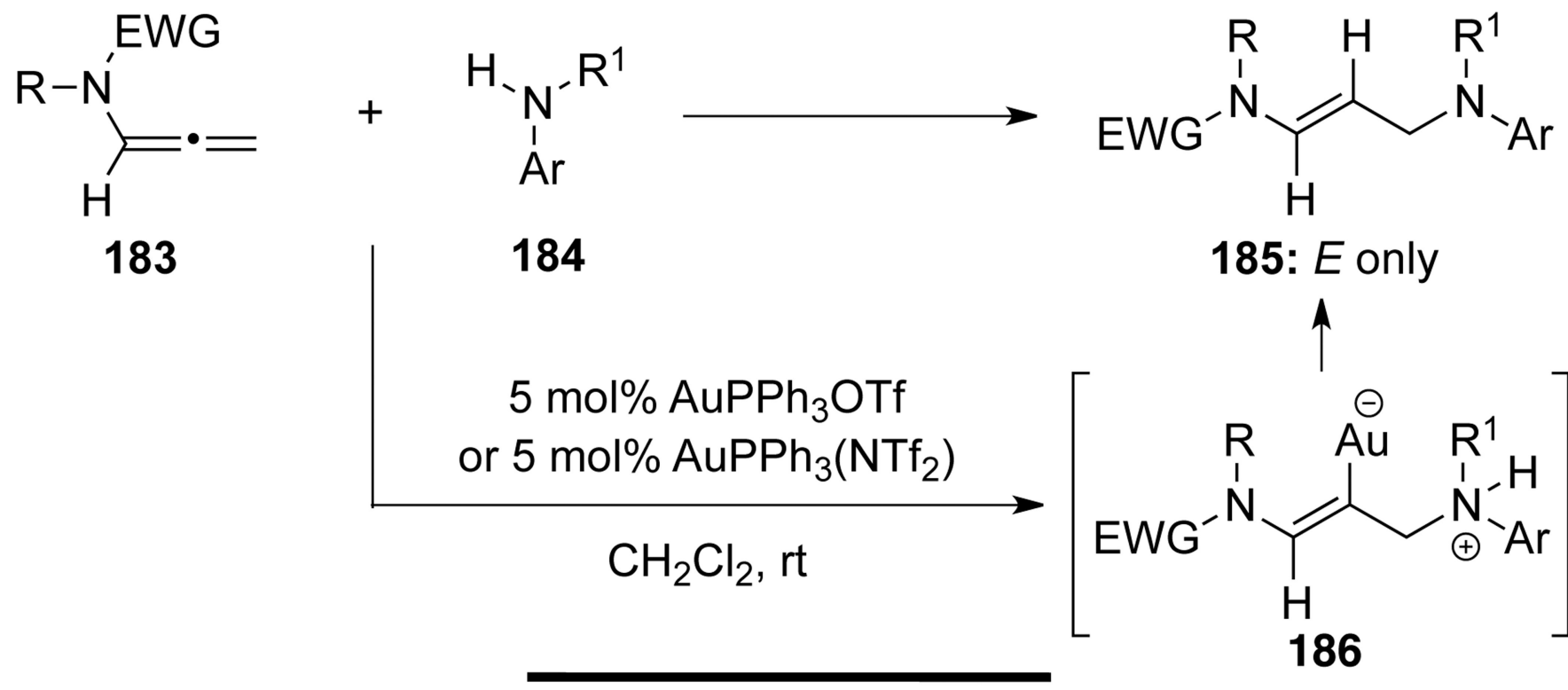<smiles>O=C1OCCN1/C=C/CNc1ccccc1</smiles>

185a: $84 \%$<smiles>COc1ccc(NC/C=C/N2CCOC2=O)c([N+](=O)[O-])c1</smiles>

185d: $99 \%$<smiles>O=C1OCCN1/C=C/CNc1ccccc1F</smiles>

185b: $90 \%$
185: E only

$\uparrow$

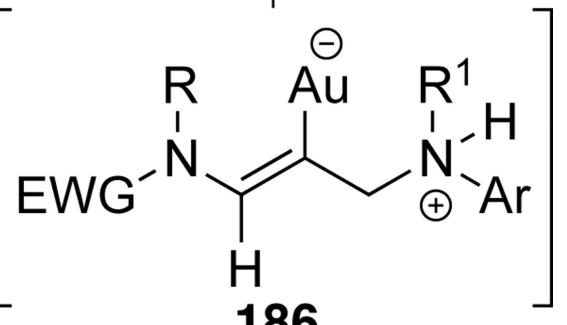

186<smiles>COc1cccc(NC/C=C/N(C)OC(=O)c2ccccc2)c1</smiles>

Scheme 54. 


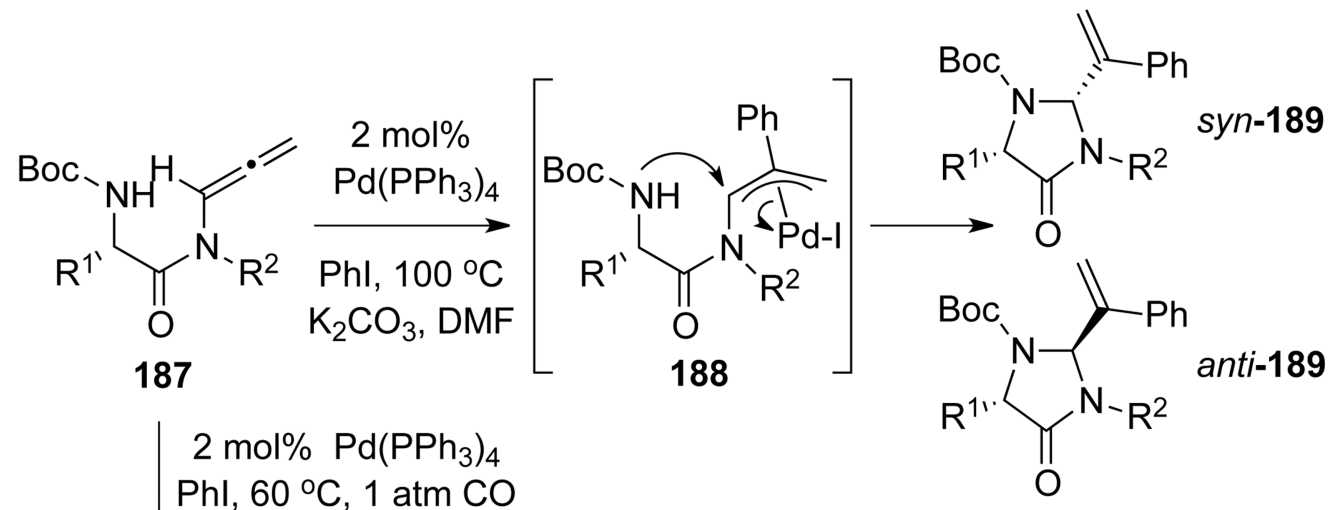

$\mathrm{Phl}, 60^{\circ} \mathrm{C}, 1 \mathrm{~atm} \mathrm{CO}$

$\mathrm{K}_{2} \mathrm{CO}_{3}, \mathrm{DMF}$

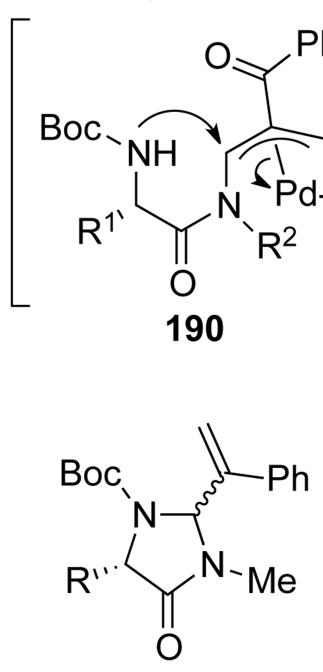

189a: $\mathrm{R}=\mathrm{Me}$

[77\%; syn/anti: 5.5:1] 189b: $\mathrm{R}=\mathrm{Ph}$

[72\%; syn/anti: 2.6:1]<smiles>C=C(C(=O)c1ccccc1)[C@H]1N(C)C(=O)[C@@H](C(C)C)N1C(=O)OC(C)(C)C</smiles>

191a: $59 \%$, syn/anti: $1: 7.4$

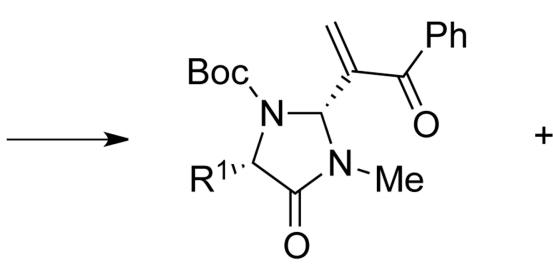

syn-191<smiles>C=C1c2ccccc2CN2C(=O)[C@H](C)N(C(=O)OC(C)(C)C)[C@@H]12</smiles>

189c: $51 \%$, syn only<smiles>[R1]C1C(=O)N(C)N(C(=O)OC(C)(C)C)[C@H]1C(=C)C(=O)c1ccccc1</smiles>

anti-191

Scheme 55.

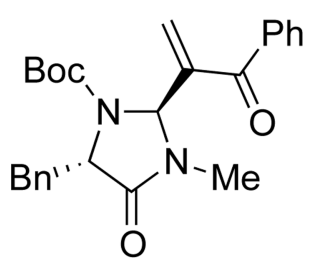

191b: $40 \%$, anti only<smiles>C=C(C(=O)c1ccccc1)[C@H]1N(C)C(=O)[C@H](c2ccccc2)N1C(=O)OC(C)(C)C</smiles>

191c: $67 \%$, anti only 


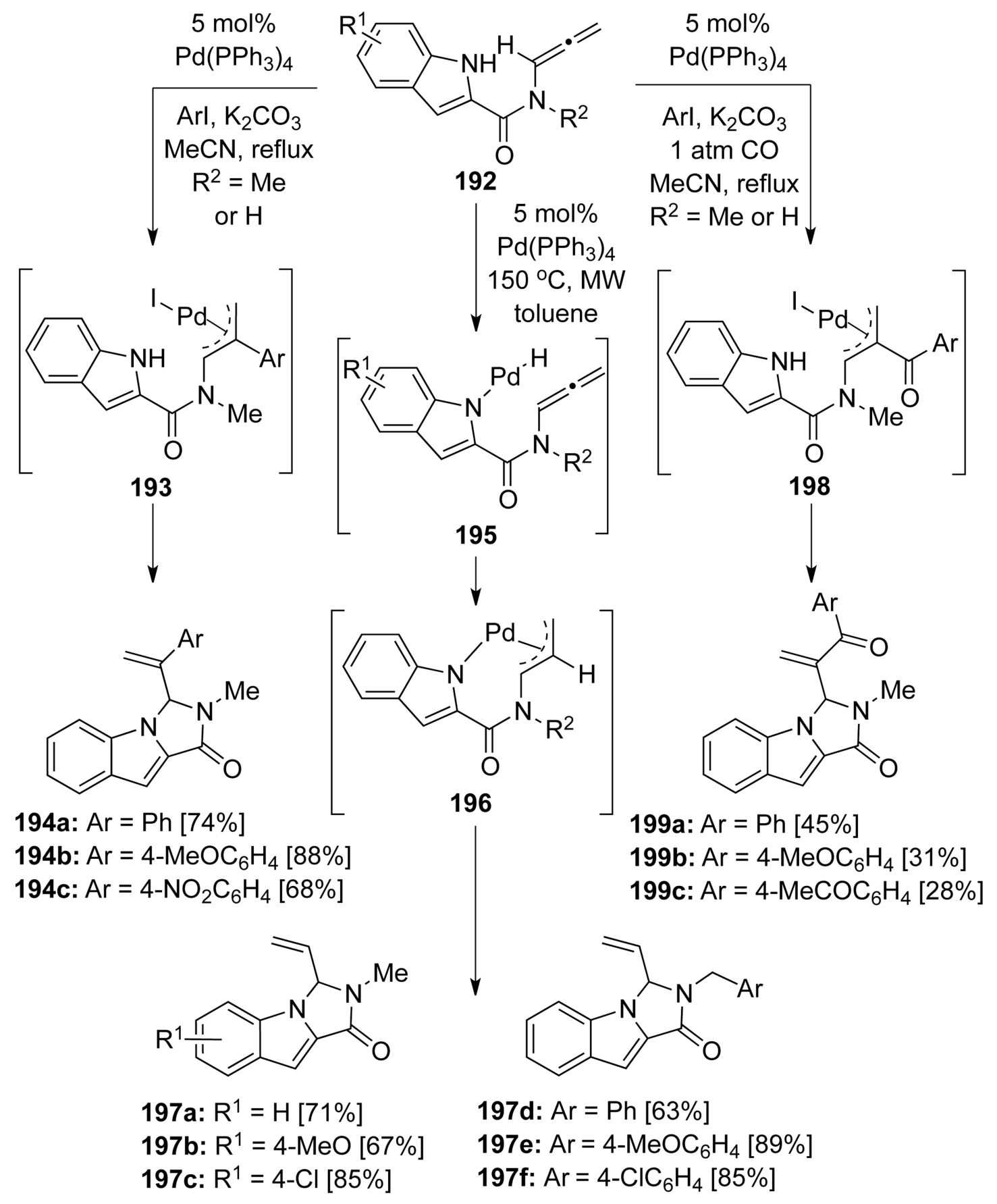

Scheme 56. 
<smiles>[R7]Nc1ccc([R6])cc1C(=O)N([R])C=C=C</smiles>

200

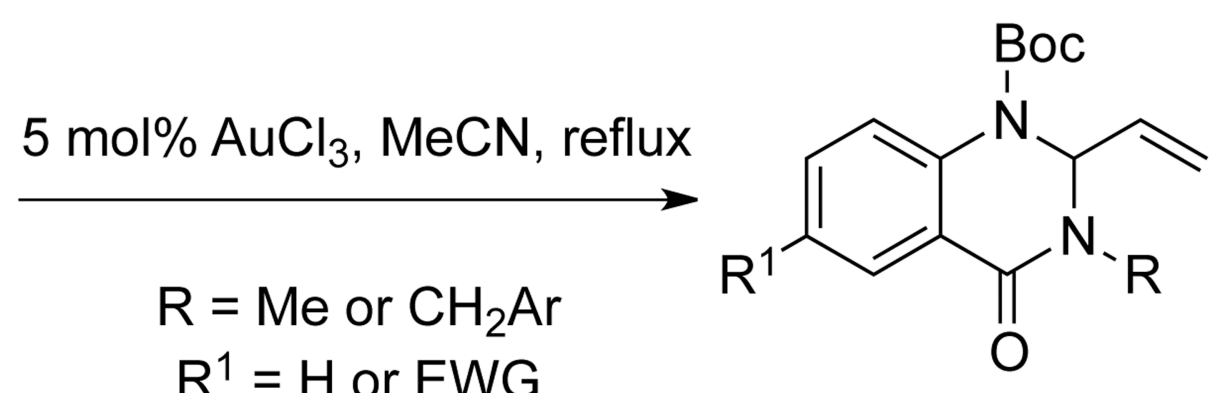

201: $41 \%-75 \%$

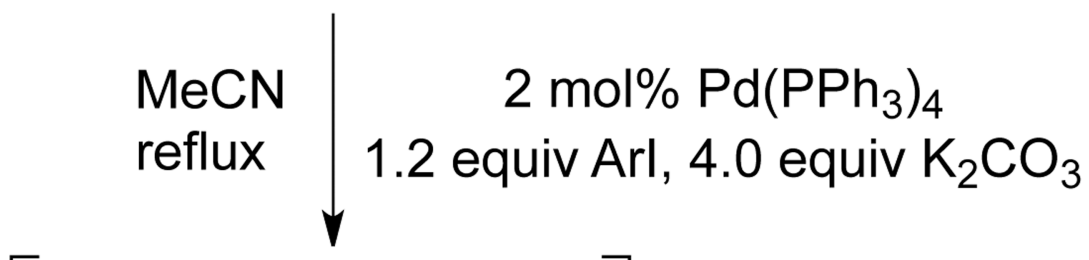

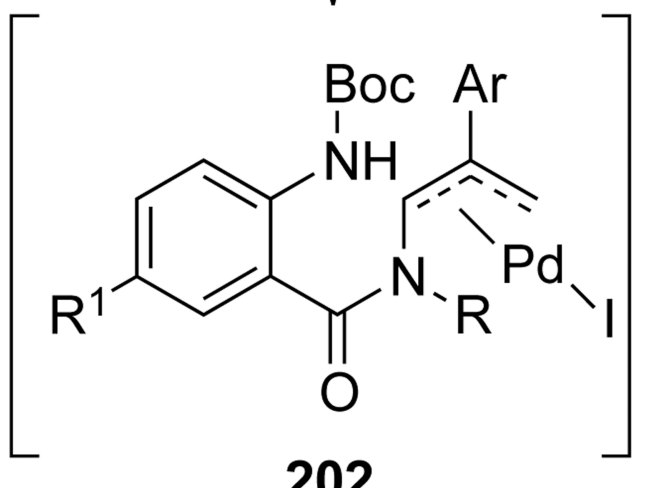<smiles>[R7]c1ccc2c(c1)C(=O)N([R])C(C(=C)[AlH2])N2[R6]</smiles>

Scheme 57. 


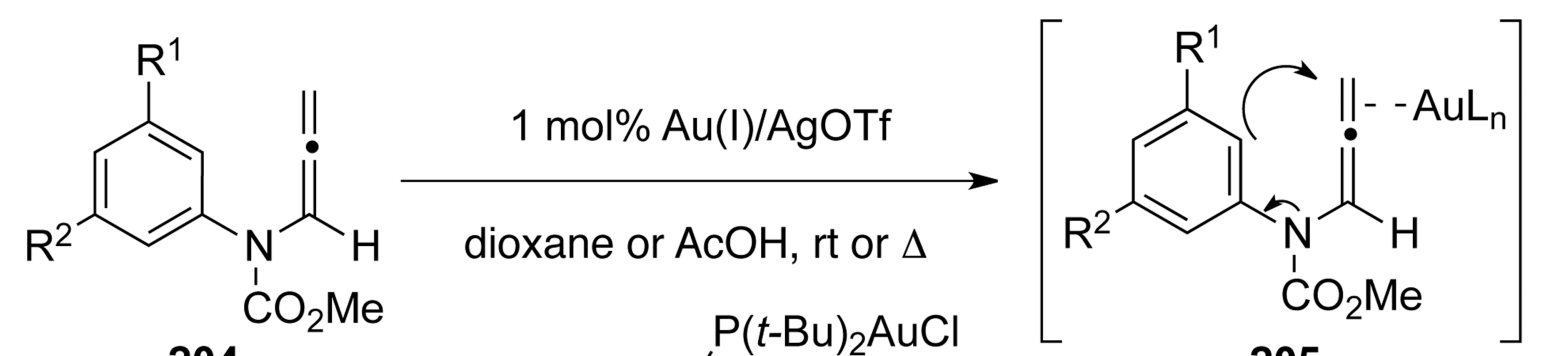
204

$\mathrm{Au}(\mathrm{I})$ :

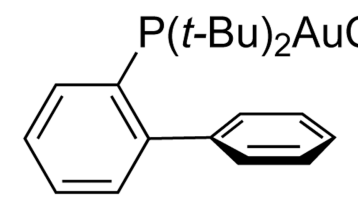

205<smiles>[R]c1cc([R])c2c(c1)N(C(C)=O)C=CC2</smiles><smiles>[R]c1cc([R1])c2c(c1)N(C(C)=O)C=C([AlH]C)C2</smiles>

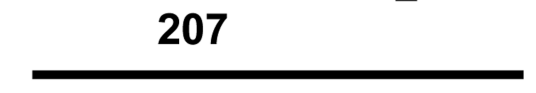<smiles>[R]c1cc([R])c2c(c1)[C@H]1CC([AlH2])=C[N+]([CH])=C1C2</smiles>
206<smiles>COc1cc(OC)c2c(c1)N(C)C=CC2</smiles>
$\mathrm{CO}_{2} \mathrm{Me}$<smiles>COC(=O)N1C=CCc2c(C)cc(C)cc21</smiles>
208a: $92 \%$ 208b: $88 \%$<smiles>COC(=O)N1C=CCc2cc(C)ccc21</smiles><smiles>Cc1cccc2c1CC=CN2</smiles>
208c: $44 \%$ 208d: $28 \%$<smiles>COC(=O)N1C=CCc2ccccc21</smiles>

208e: $40 \%$<smiles>COC(=O)N1C=CCc2cc3c(cc21)OCO3</smiles>

208f: $88 \%$<smiles>COC(=O)N1C=CCc2c1cc(OC)cc2N1C=CCc2c(OC)cc(OC(=O)OC(C)(C)C)cc21</smiles>

Scheme 58. 


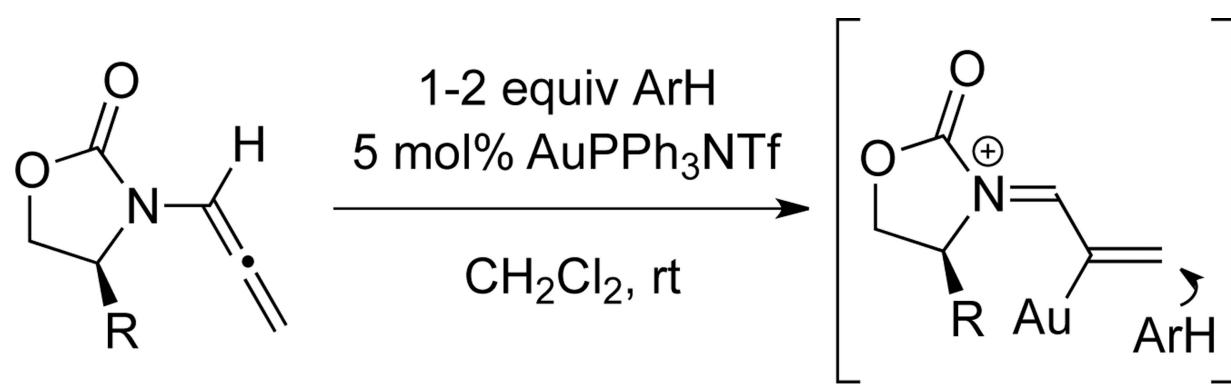

210: 1,4-add

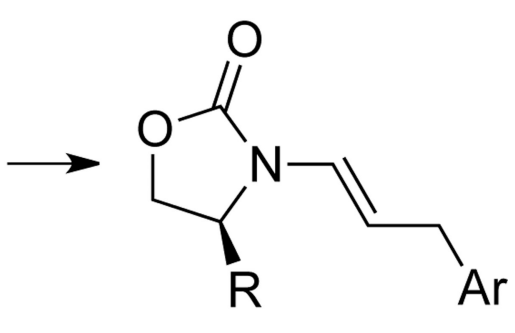

211: E-selective

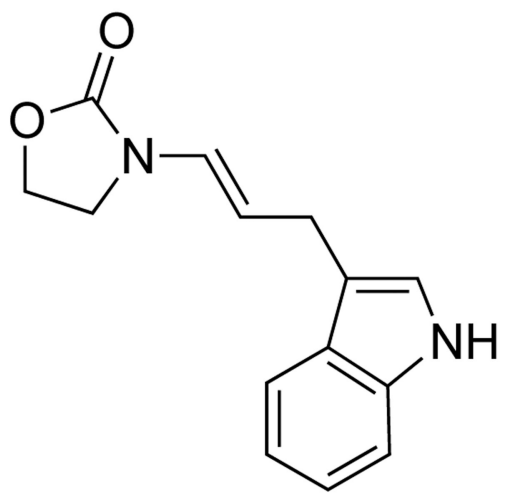

211a: $82 \%$

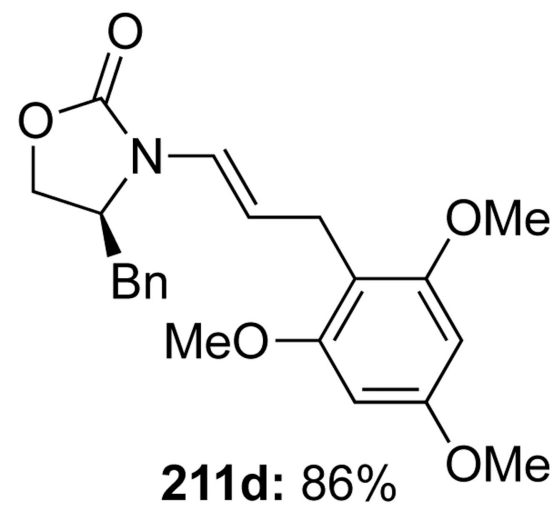

Scheme 59.

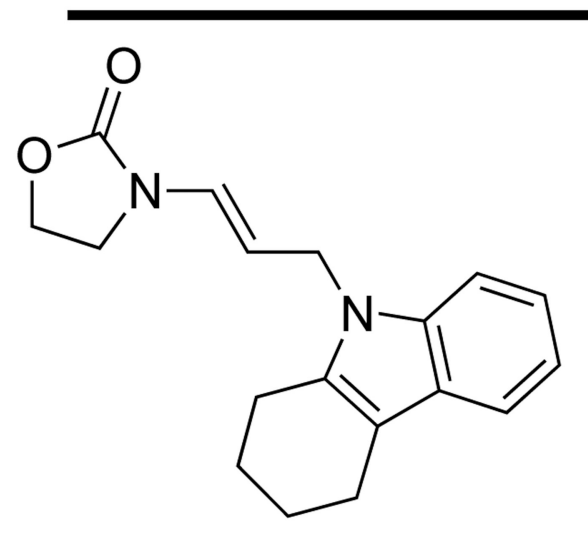

211b: $78 \%$<smiles>Cc1ccc(CCC(c2ccc(C)o2)N2CCOC2=O)o1</smiles>

211c: $48 \%$<smiles>Cn1c(CC/C=C/N2C(=O)OC[C@@H]2Cc2ccccc2)ccc1CC/C=C/N1C(=O)OC[C@H]1Cc1ccccc1</smiles>

211e: $82 \%$ ( 2 equiv of 209 added) 


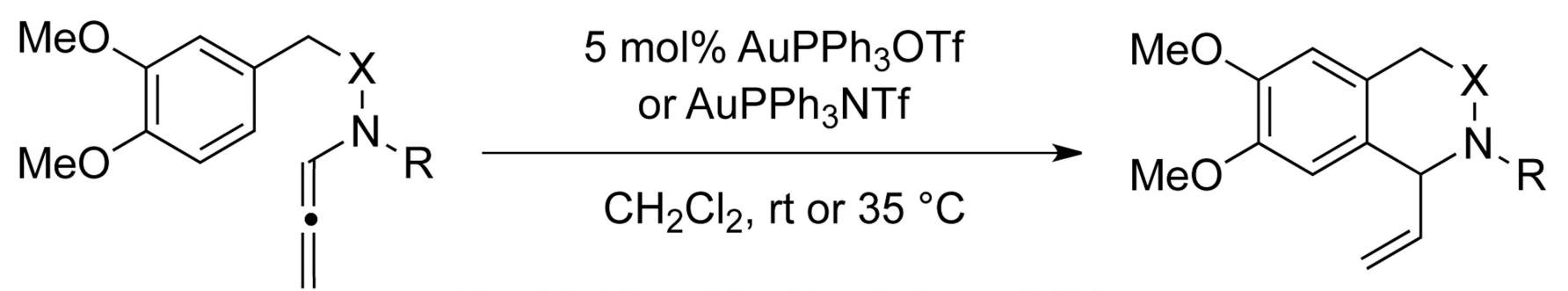

212 $\mathrm{R}=\mathrm{EWG}$ or $\mathrm{Me} ; \mathrm{X}=\mathrm{CH}_{2}$ or $\mathrm{C}(\mathrm{O})$

213<smiles>C=CC1c2cc(OC)c(OC)cc2CC(=O)N1C</smiles>

213a: 91\%-95\% Scheme 60.<smiles>C=CC1c2cc(OC)c(OC)cc2CCN1C(=O)OC(C)(C)C</smiles>

213b: $0 \%$<smiles>C=C[C@H]1c2cc(OC)c(OC)cc2C[C@@H]2COC(=O)N12</smiles>

213c: $97 \%-98 \%, d r>99: 1$ 
<smiles>[R]/C=C\[SH](=O)O[Na]</smiles>

215<smiles>[R]C1[Te]C(=CN(C)c2ccccc2)C[C@H]1S(C)(=O)=O</smiles>

216

Scheme 61.

217a: $\mathrm{R}=\mathrm{Ph}[88 \%]$

217b: $\mathrm{R}=n$-hex [74\%]

217c: $\mathrm{R}=\left(\mathrm{CH}_{2}\right)_{2} \mathrm{Ph}[70 \%]$

\section{Scheme 61.}


<smiles>C=C=CN1C(=O)OC[C@H]1P</smiles><smiles>CCOC(=O)Cl</smiles>

219

220: $28 \%, E / Z>95: 5$
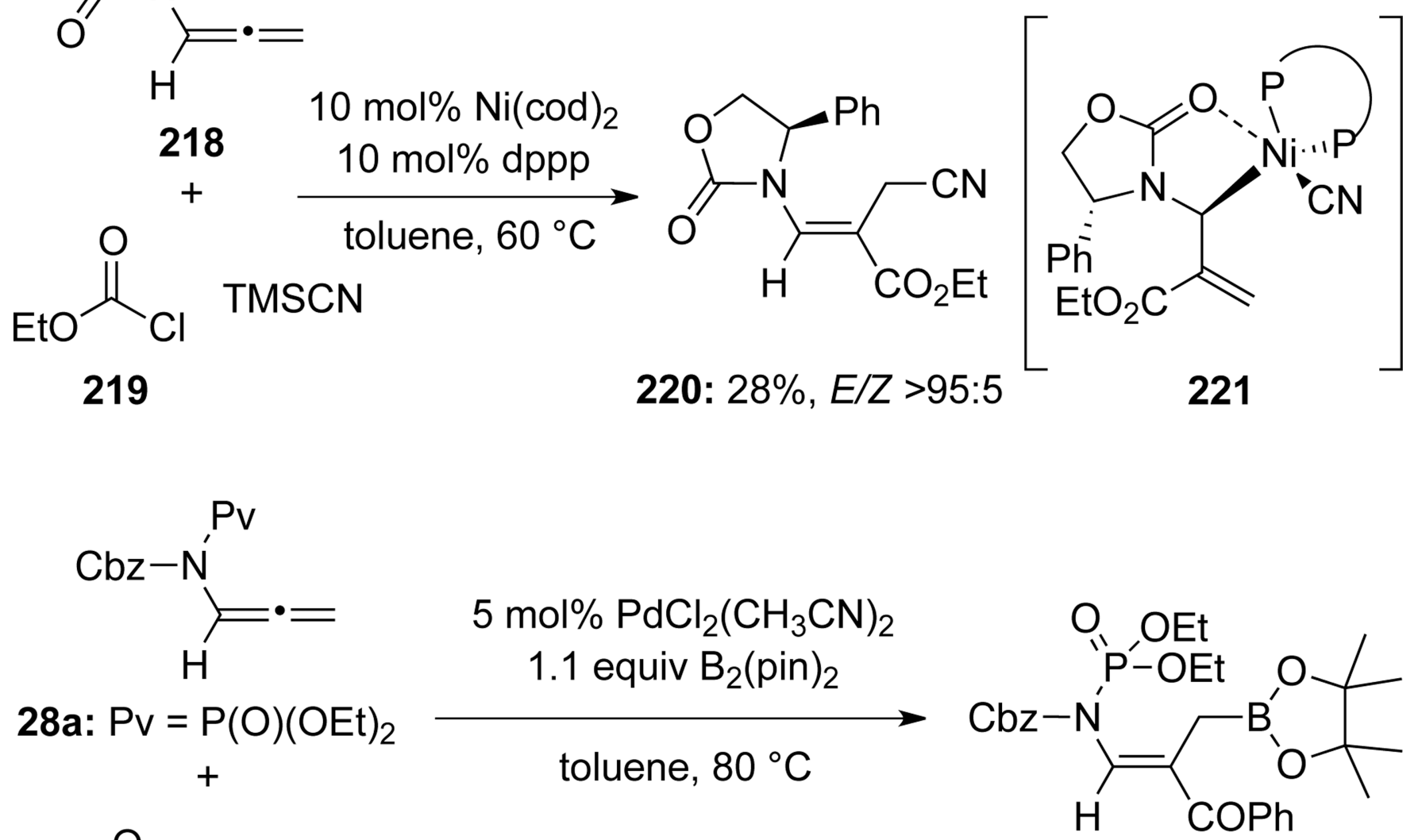<smiles>O=C(Cl)Pc1ccccc1</smiles>

222: $47 \%, E / Z>9: 1$

Scheme 62. 

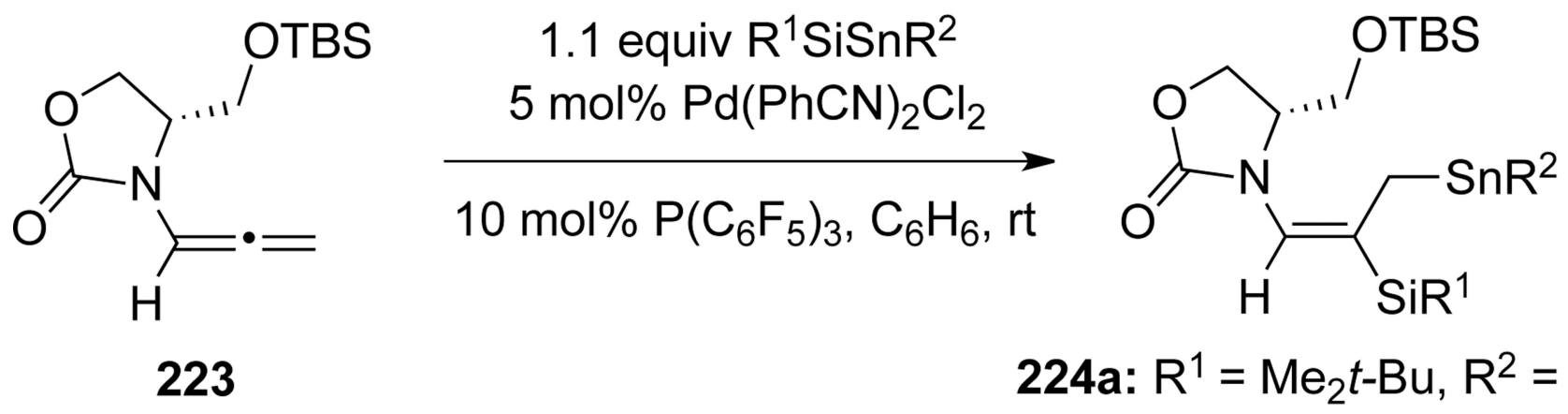

224a: $R^{1}=\mathrm{Me}_{2} t-\mathrm{Bu}, \mathrm{R}^{2}=\mathrm{Ph}_{3}$ [60\%, E only]

224b: $\mathrm{R}^{1}=\mathrm{Me}_{3}, \mathrm{R}^{2}=t-\mathrm{Bu}_{3}$ [47\%, E/Z >99:1]

Scheme 63. 


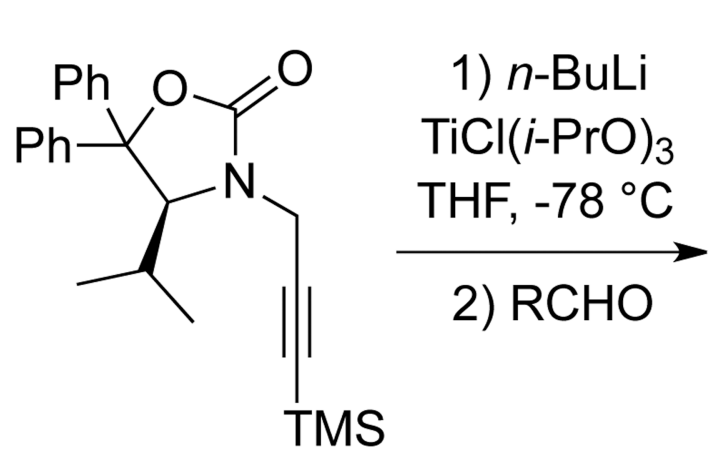

225<smiles>CC(C)C(=C=CN1C(=O)OC(c2ccccc2)(c2ccccc2)[C@H]1C(C)C)[C@@H](O)C(C)C</smiles>

226a: $67 \%, d r 97: 3$<smiles>[R]C(O)C(C)=C=CN1C(=O)OC(c2ccccc2)(c2ccccc2)[C@H]1C(C)C</smiles>

226

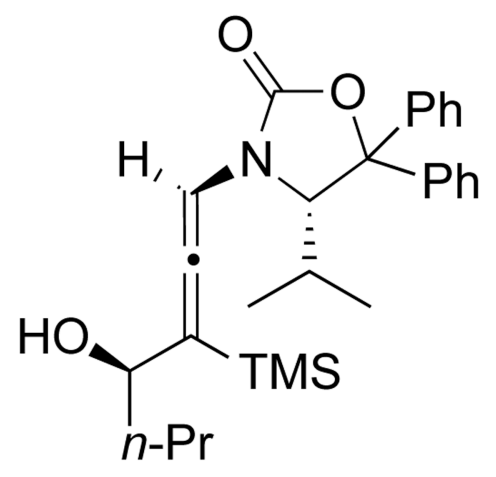

226b: $66 \%, d r 97: 3$

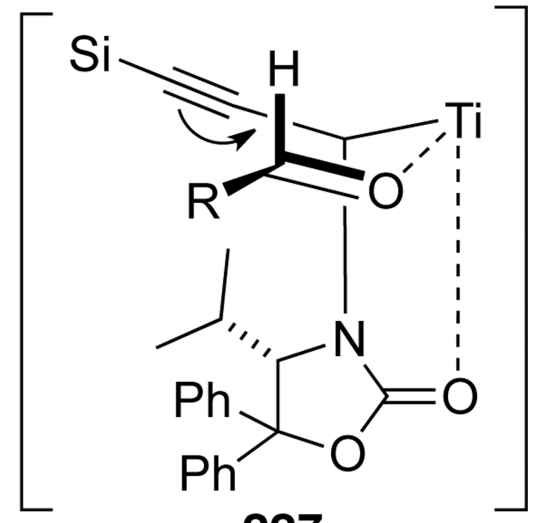

227<smiles>C=C(C)[C@H](O)C(=C=CN1C(=O)OC(c2ccccc2)(c2ccccc2)[C@H]1C(C)C)C(C)C</smiles>

226c: $60 \%, d r 98: 2$

Scheme 64. 


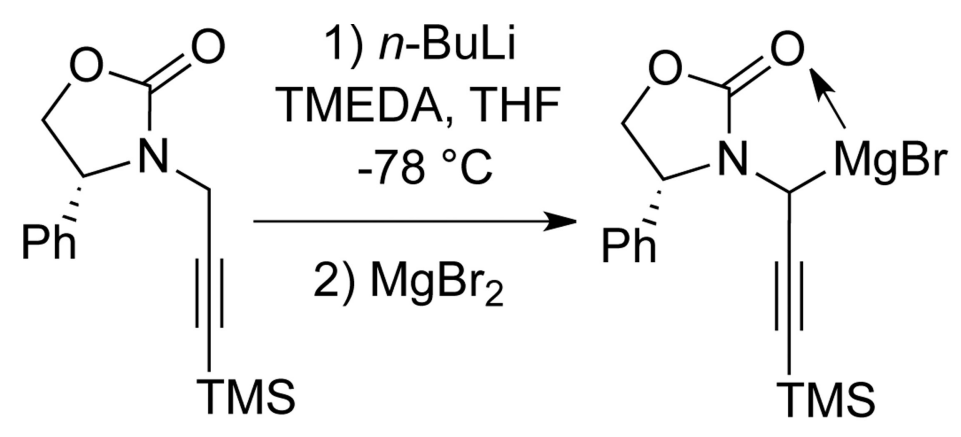

228

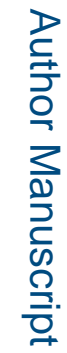

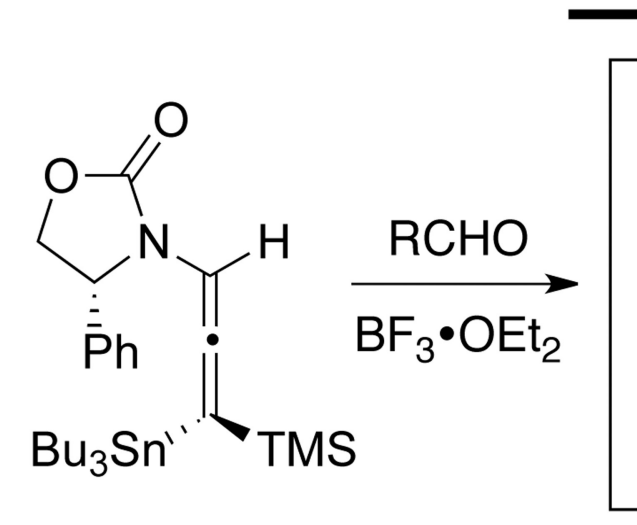

230
Scheme 65.

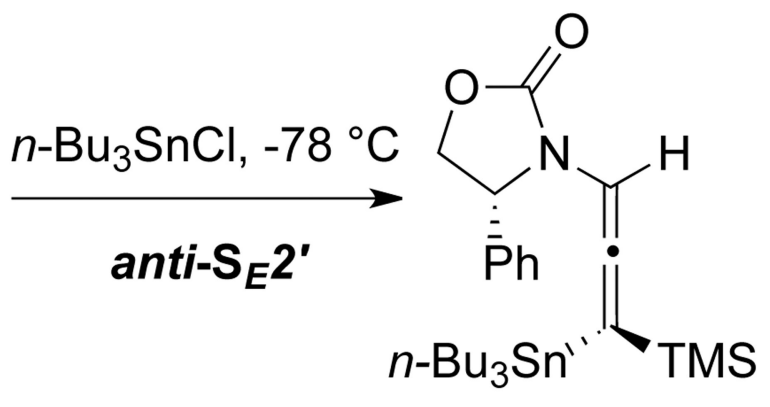

230: $80 \%, d r>95: 5$

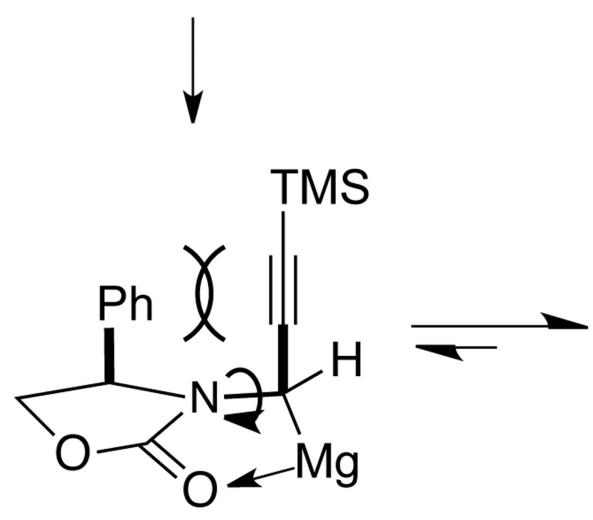

231

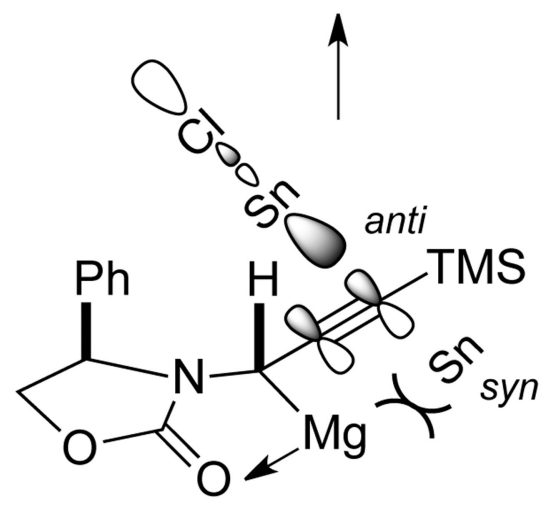

232
233

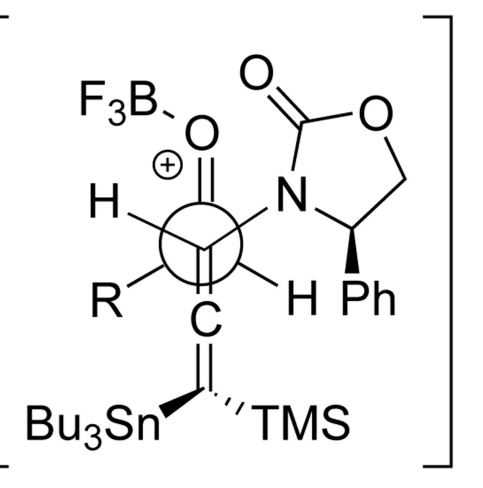<smiles>[R]C(O)[C@H](C#C[Y5](C)(C)C)N1C(=O)OC[C@H]1Pc1ccccc1</smiles>

$\mathrm{R}=$ alkyl or aryl

234: $68 \%-95 \%$

$d r$ up to $>95: 5$ 


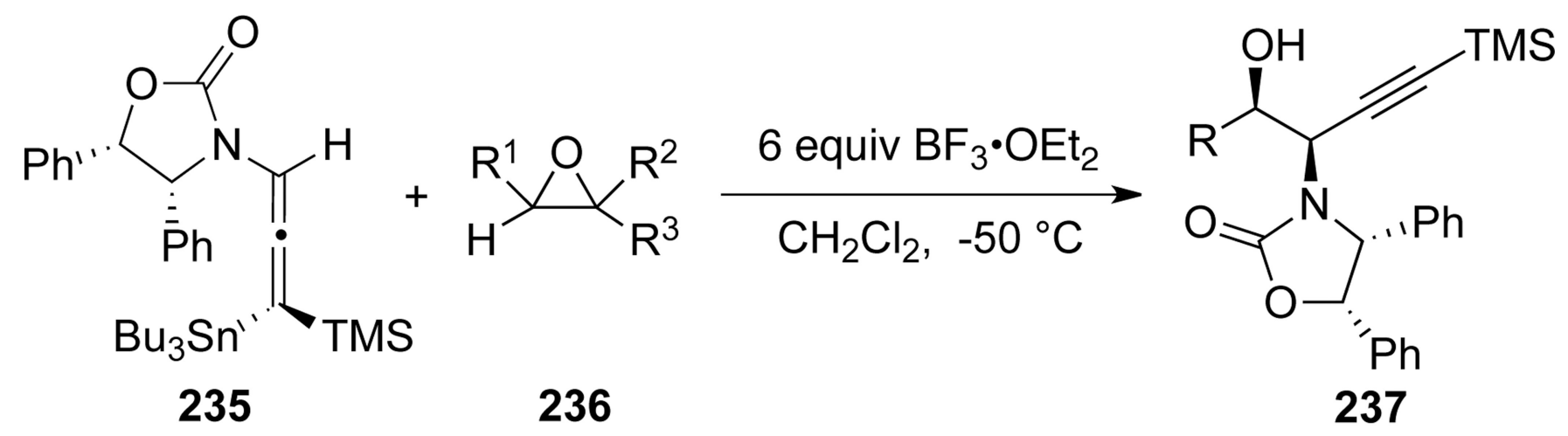<smiles>C=CC[C@@H](O)[C@H](C#C[As])N1C(=O)O[C@@H](P)[C@H]1P</smiles>

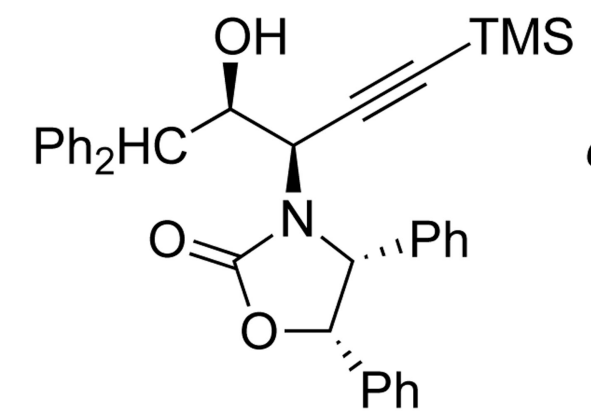<smiles>C[As]C#C[C@H]([C@H](O)[Y20](C)(C)C)N1C(=O)O[C@@H](P)[C@@H]1c1ccccc1</smiles>

237a: $66 \%, d r>95: 5$

237b: $74 \%, d r 94: 6$

237c: $70 \%, d r 95: 5$

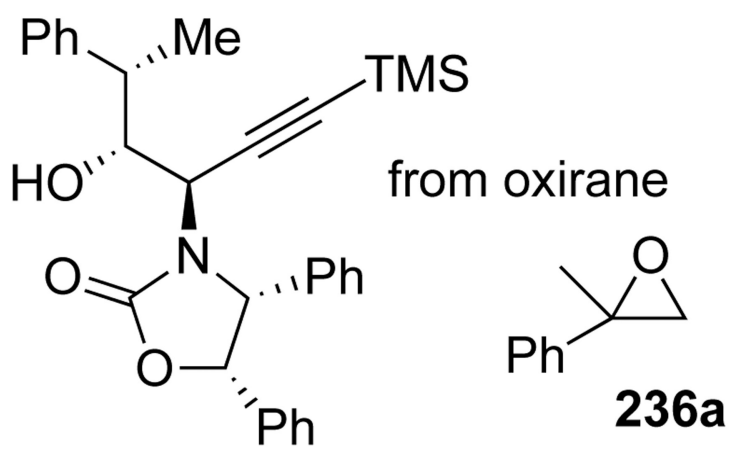

237d: $79 \%, d r 84: 16$

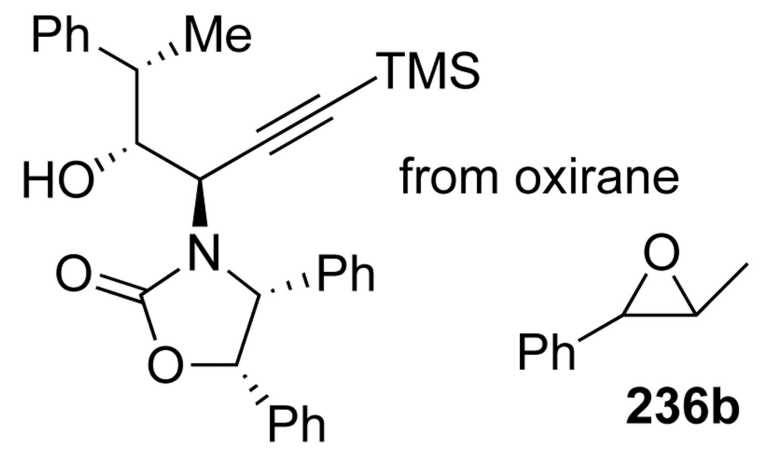

237e: $17 \%$, dr 90:10

Scheme 66. 


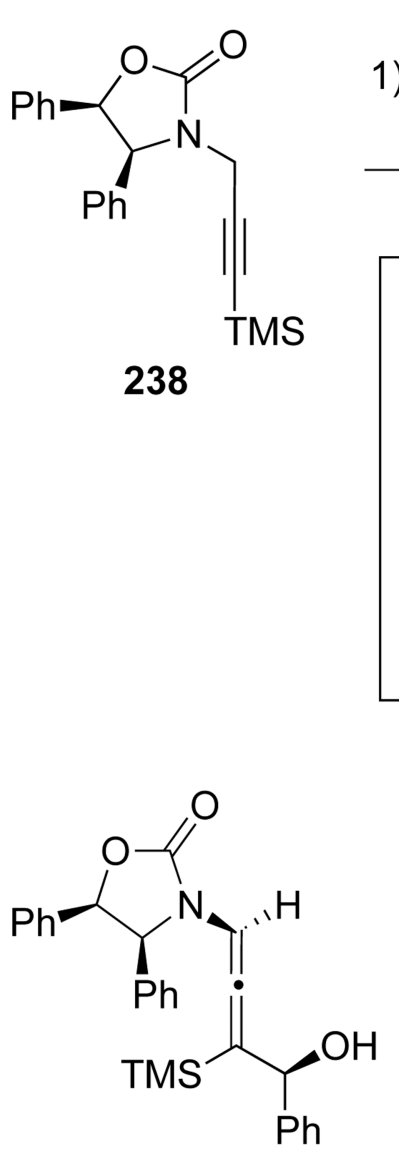

240a: $87 \%, d r$ 83:17<smiles>C/C=C\[C@@H](/C=C(\S)[C@@H](O)/C=C/C)N1C(=O)O[C@H](c2ccccc2)[C@H]1P</smiles>

240d: $72 \%, d r 81: 19$
1) $n$-BuLi, TMEDA, THF, $-78{ }^{\circ} \mathrm{C}$

2) $\mathrm{B}-\mathrm{MeO}-9-\mathrm{BBN}$

3) $\mathrm{RCHO}, \mathrm{BF}_{3} \cdot \mathrm{OEt}_{2}$

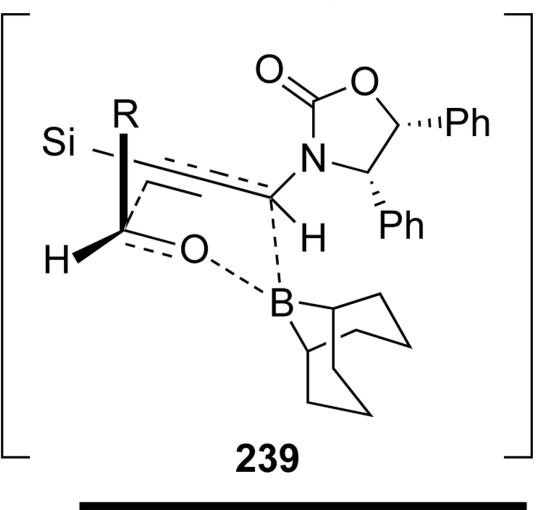<smiles>CCCC(C)[C@H](O)C(S)=C=CN1C(=O)O[C@@H](c2ccccc2)[C@@H]1P</smiles>

240b: $87 \%, d r 77: 23$<smiles>C=CCC[C@H](O)C(C)=C=CN1C(=O)O[C@@H](c2ccccc2)[C@H]1P</smiles>

240e: $86 \%, d r 83: 17$<smiles>[R]C(O)/C(=C/N=C/N1C(=O)O[C@@H](c2ccccc2)[C@@H]1c1ccccc1)S(C)(=O)=O</smiles>

anti-240<smiles>Cc1ccc([C@H](O)C(S)=C=CN2C(=O)O[C@@H](c3ccccc3)[C@H]2c2ccccc2)o1</smiles>

240c: $61 \%, d r 83: 17$<smiles>C[C@H](Oc1ccccc1)[C@@H](O)C(S)=C=CN1C(=O)O[C@@H](c2ccccc2)[C@H]1P</smiles>

240f: $78 \%, d r 88: 12$

Scheme 67. 


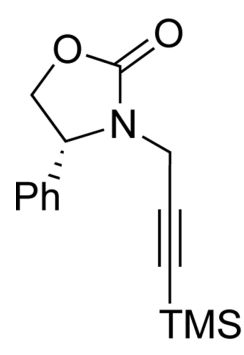

228

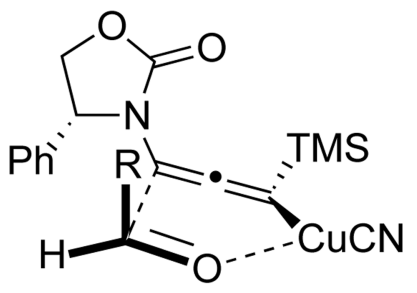

TS for antia 241
1) s-BuLi, TMEDA THF, $-80^{\circ} \mathrm{C}$

2) $\mathrm{CuCN}, \mathrm{LiBr}$ 3) $\mathrm{RCHO}$<smiles>[R]C(O)[C@H](C#C[Y5](C)(C)C)N1C(=O)OC[C@H]1c1ccccc1</smiles>

anti $_{\mathrm{a}} 241$<smiles>[R]C(O)C(C#C[As])N1C(=O)OC[C@H]1c1ccccc1</smiles>

anti $_{\mathrm{S}} 241$<smiles>[R]C(O)[C@H](C#C[Y5](C)(C)C)N1C(=O)OC[C@H]1c1ccccc1</smiles>

$\operatorname{syn}_{a} 241$<smiles>[R]C(O)CC#C[As]</smiles>

$s y n_{s} 241$<smiles>[Y][CH]C[C@H](O)[C@@H](C#C[As])N1C(=O)OC[C@H]1c1ccccc1</smiles><smiles>CCCCC(=O)N1C(=O)OC[C@H]1c1ccccc1</smiles><smiles>CC(C)(C)[C@H](O)[C@@H](C#C[As])N1C(=O)OC[C@H]1c1ccccc1</smiles>

241a: $88 \%$, dr 95:5 241b: $83 \%, d r 93: 7$

241c: $84 \%$, anti $i_{a}$ only<smiles>CC(C)(C)C#C[C@H]([C@H](O)C#CPO[GaH2])N1C(=O)OC[C@H]1c1ccccc1</smiles><smiles>C[SH](C)(C)(C)C#C[C@H]([C@H](O)c1ccccc1)N1C(=O)OC[C@H]1c1ccccc1</smiles>

$\mathrm{R}=$ alkyl, alkenyl alkynyl, anti only; $d r=$ anti $_{a}:$ :anti $_{s}$;

For $\mathrm{R}=\mathrm{Ph}, d r=$ anti $_{\mathrm{a}}: \mathrm{anti}_{\mathrm{s}}: \mathrm{syn}_{\mathrm{a}}$

241d: $75 \%, d r$ 86:14 241e: $52 \%$, $d r$ 59:9:32

Scheme 68 . 


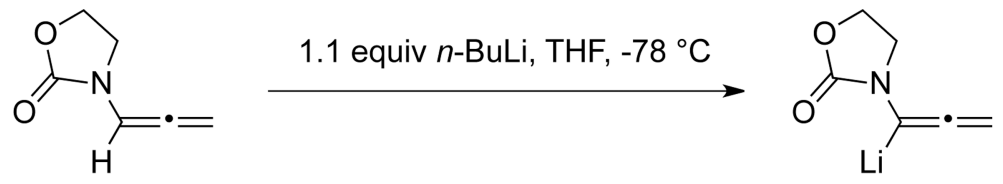

242

243<smiles>[R]C=C([R])C(=O)CC([R9])C</smiles><smiles>[R]C=C([R1])C(=O)C(=C(C)[GeH2])N1CCOC1=O</smiles>

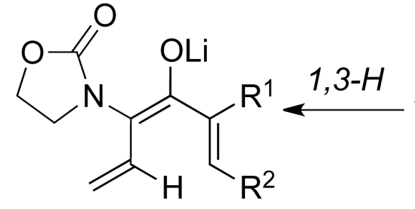<smiles>[R]C=C1CC(=C)C1(OCl)C([R1])=C1NCCOC1=O</smiles>

246

245

244<smiles>CC(=O)O[R6](C)(=O)(O)C(=O)Oc1ccc(C(=O)C(=C(C)C)N2CCOC2=O)cc1</smiles><smiles>CC=C(C(=O)c1ccco1)N1CCOC1=O</smiles><smiles>CC=C(C(=O)c1cccc2ccccc12)N1CCOC1=O</smiles>

246e: $52 \%$<smiles>C/C(=C/C(=O)OCc1ccccc1)C(=O)/C(C)=C/c1ccccc1</smiles>

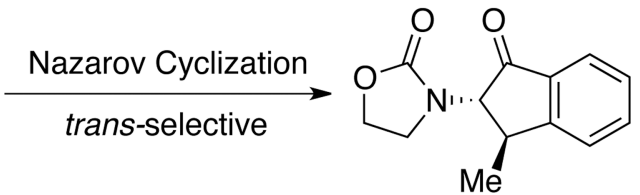<smiles>[R]c1ccc2c(c1)[C@H](C)[C@H](N1CCOC1=O)C2=O</smiles>

247a: $\operatorname{lnOTf}{ }_{3}[65 \%$ 247b: $\mathrm{TfOH}: \mathrm{R}=\mathrm{SMe}$ [97\%] $\mathrm{TfOH}[98 \%] \quad$ 247c: $\mathrm{TfOH}: \mathrm{R}=\mathrm{CO}_{2} \mathrm{Me}[91 \%]$

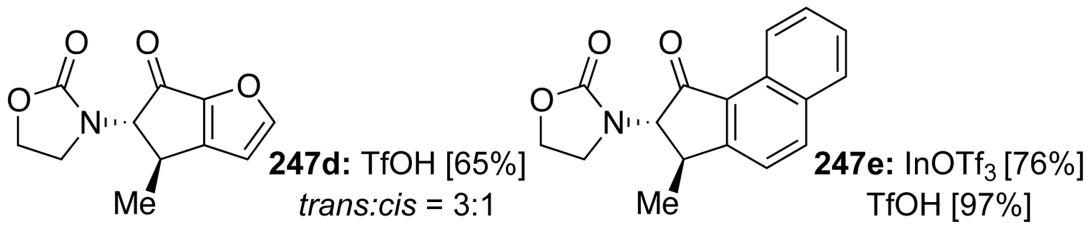

Scheme 69. 

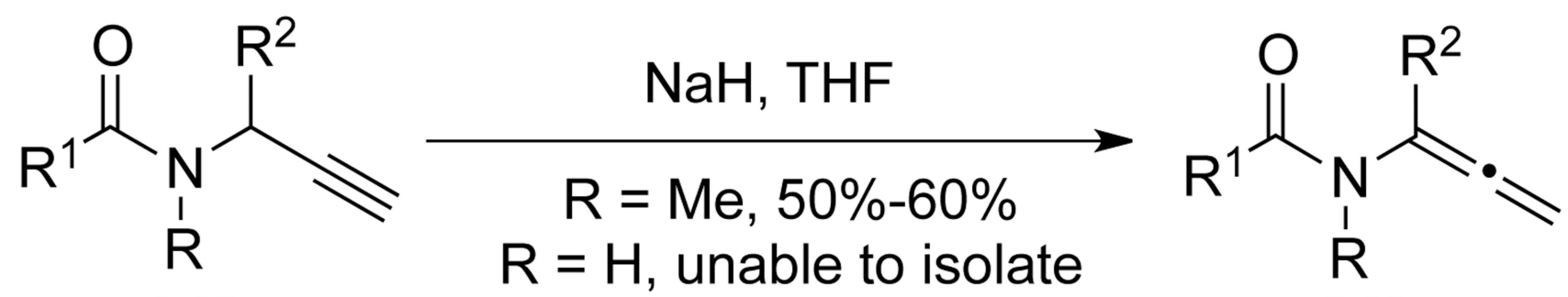

248

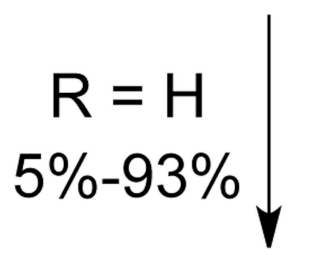

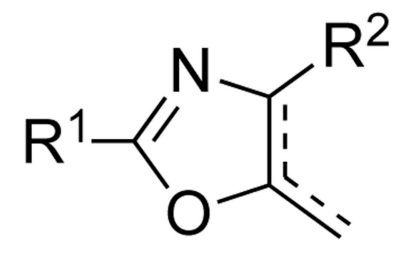

252

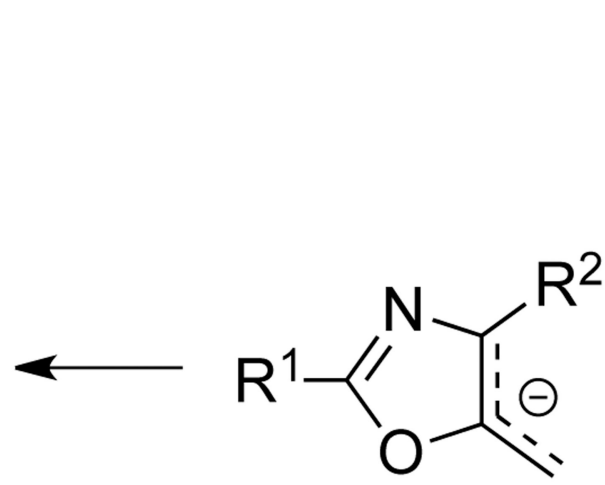

251
249

$$
\mathrm{R}^{1}=\mathrm{Me} \text { or } \mathrm{CF}_{3} ; \mathrm{R}^{2}=\mathrm{H}, \mathrm{Me}, \mathrm{Ph}, p-\mathrm{OMePh} \text { or } p-\mathrm{NO}_{2} \mathrm{Ph}
$$

Scheme 70. 


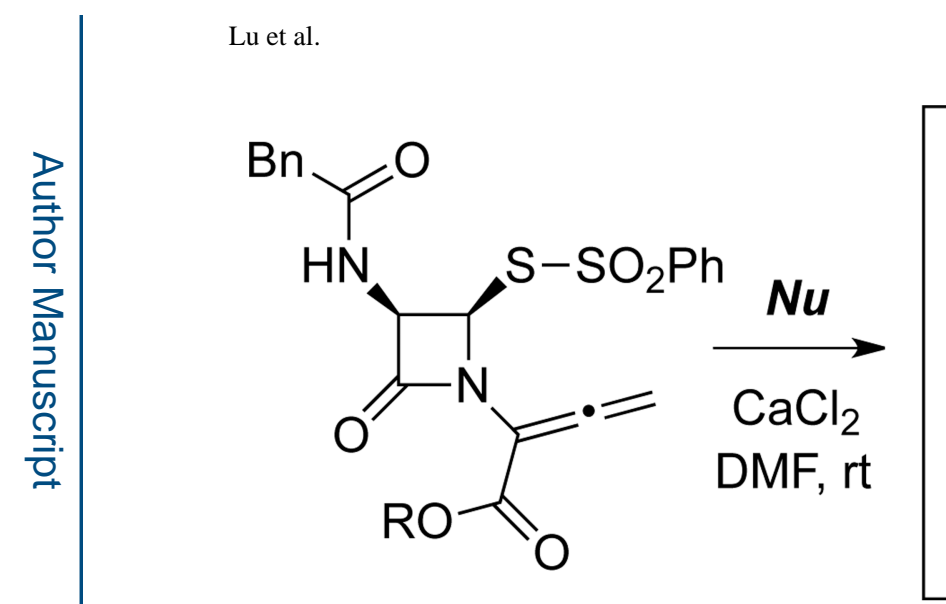

253 


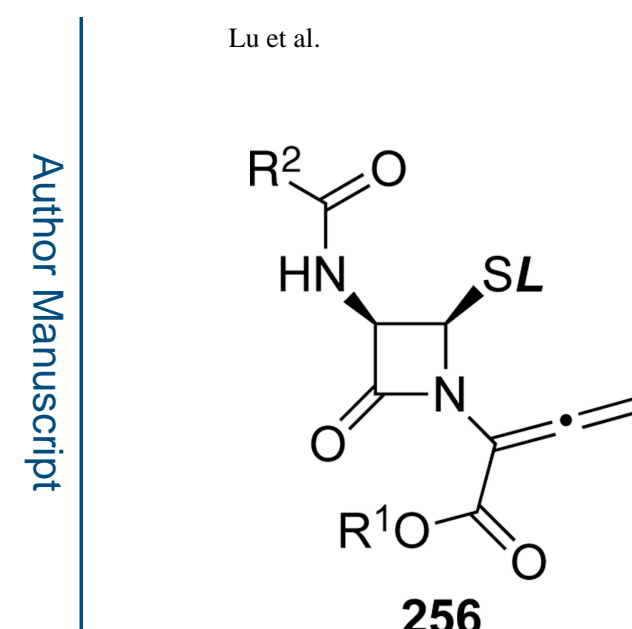

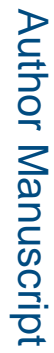<smiles>[13CH3]Sc1nc2ccccc2s1</smiles>

Scheme 72.

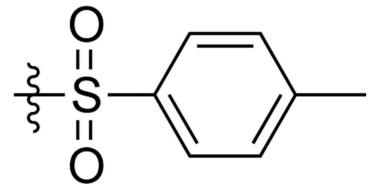

257

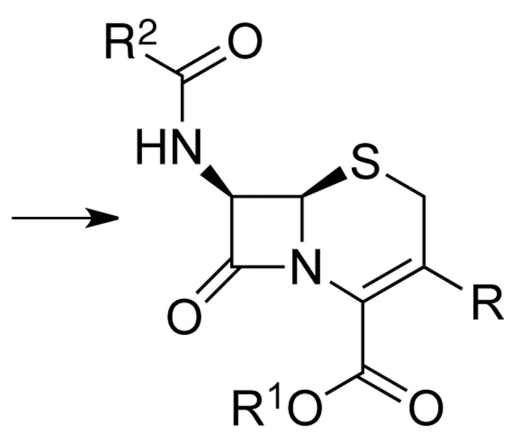

258: $75 \%-95 \%$

$$
\begin{aligned}
& \mathrm{R}=\mathrm{Me}, \mathrm{Ph} \text { or } \mathrm{Z} \text {-propenyl } \\
& \mathrm{R}^{1}=\mathrm{CHPh}_{2}, \mathrm{R}^{2}=\mathrm{CH}_{2} \mathrm{OPh}
\end{aligned}
$$


<smiles>[R]C(=O)N[C@H]1C(=O)N(C([R20])=C=C)[C@@H]1[Si]([X])(CCBr)CCBr</smiles>

259: $\mathrm{R}=\mathrm{CH}_{2} \mathrm{OPh}$

$\mathrm{LiBr}$ or $\mathrm{LiCl}$ in THF or NMP $0{ }^{\circ} \mathrm{C}$ to $\mathrm{rt}$
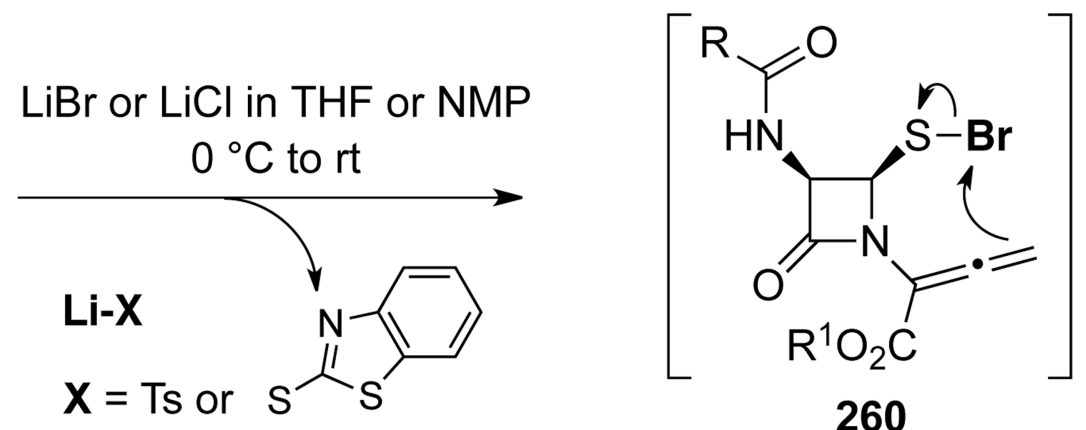

260

$\mathrm{R}$<smiles>[R]C(N)=O</smiles><smiles>C1CCNC1</smiles><smiles>CCSC</smiles><smiles>[R20]C(C)=C(C([Y])C)N1CCC1=O</smiles>

262

Li-X<smiles>[R]C(C)=O</smiles><smiles>[R20]CC1=C(Br)CS[C@@H]2[C@H](C)C(=O)N12</smiles>
1,4-add/eliminat<smiles>CCCC(CC)C(=O)OC(C)(Br)Br</smiles>

261<smiles>[R]C([Y8])=O</smiles><smiles>[R20]CC1=C(Sc2nc3ccccc3s2)CS[C@@H]2[C@H](N)C(=O)N12</smiles><smiles>[R]C(=O)N[C@@H]1C(=O)N2C([R20])=C([AsH-])CS[C@H]12</smiles><smiles>[R]C(N)=O</smiles><smiles>[R20]C1=C(Sc2nnnn2C)CS[C@@H]2[C@H](N)C(=O)N12</smiles>

Both can be derived from 259 where $X=T s$ :

262b via using 3.8 equiv $\mathrm{LiBr}$; and 262c via using 2.0 equiv $\mathrm{LiBr}$ with excess $\mathrm{Na}$-2-mercapto-tetrazolate Scheme 73. 

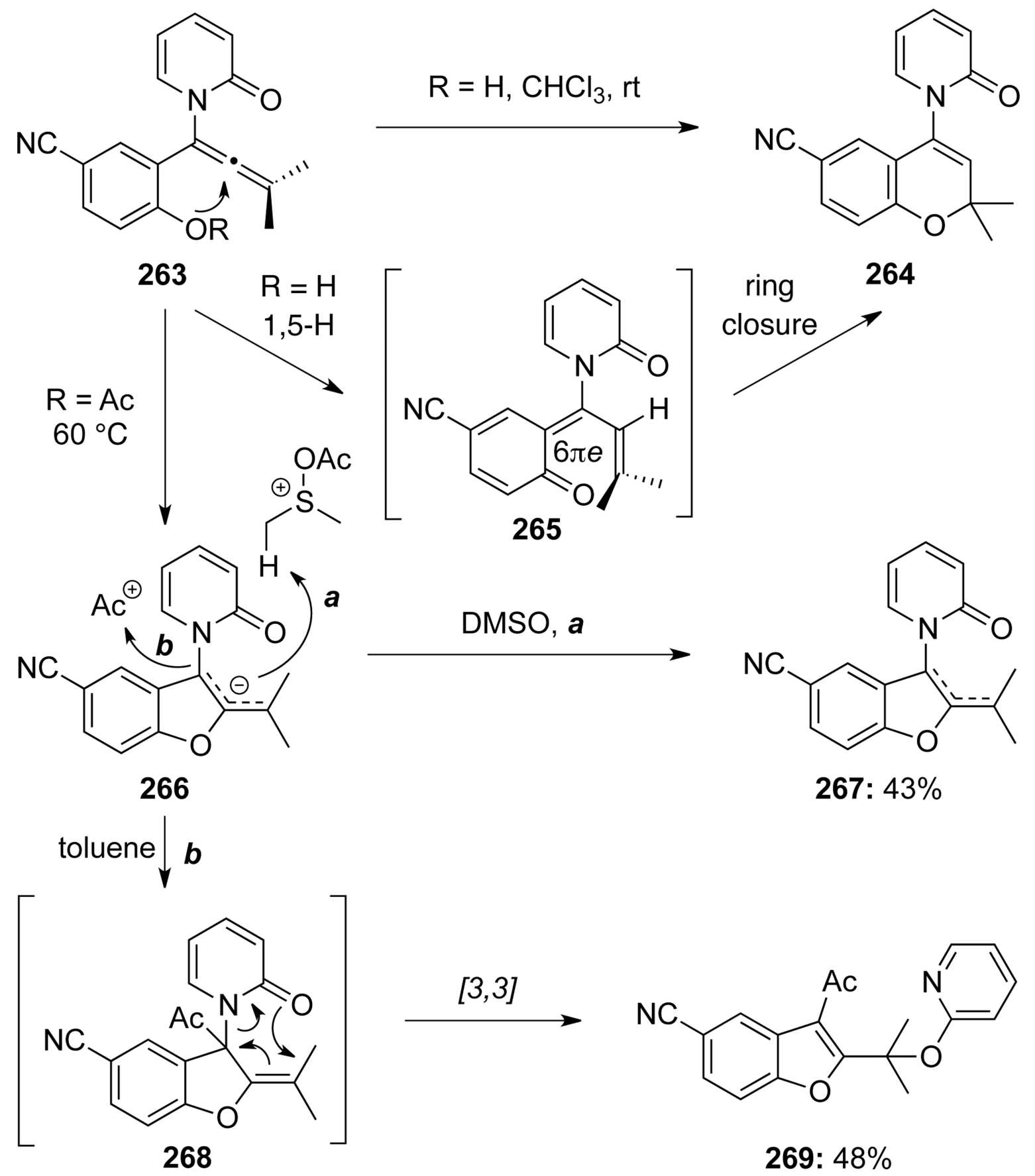

Scheme 74. 


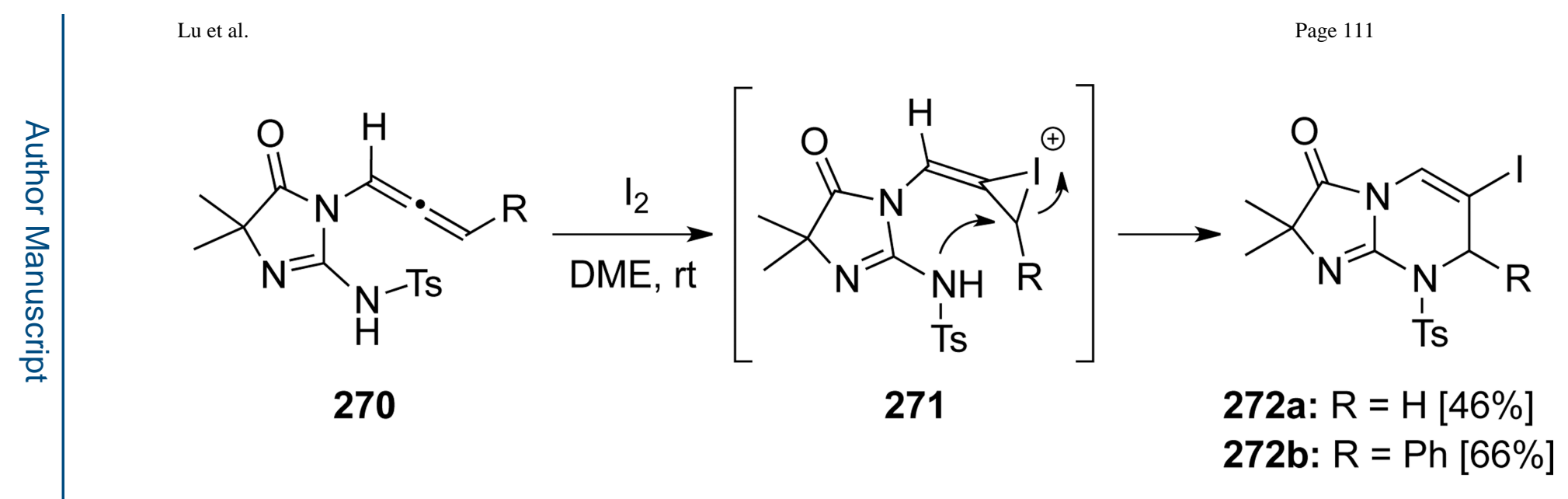

Scheme 75. 


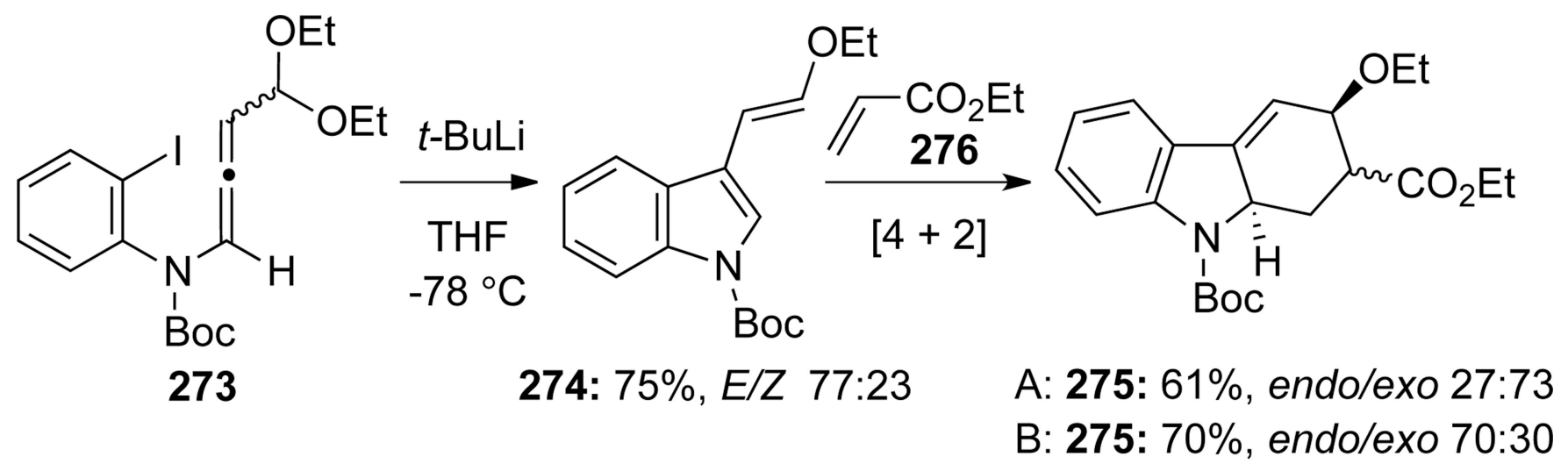

For [4 + 2]: Method A: toluene, $110{ }^{\circ} \mathrm{C}$; Method B: THF, rt, 12 Kbar Scheme 76. 


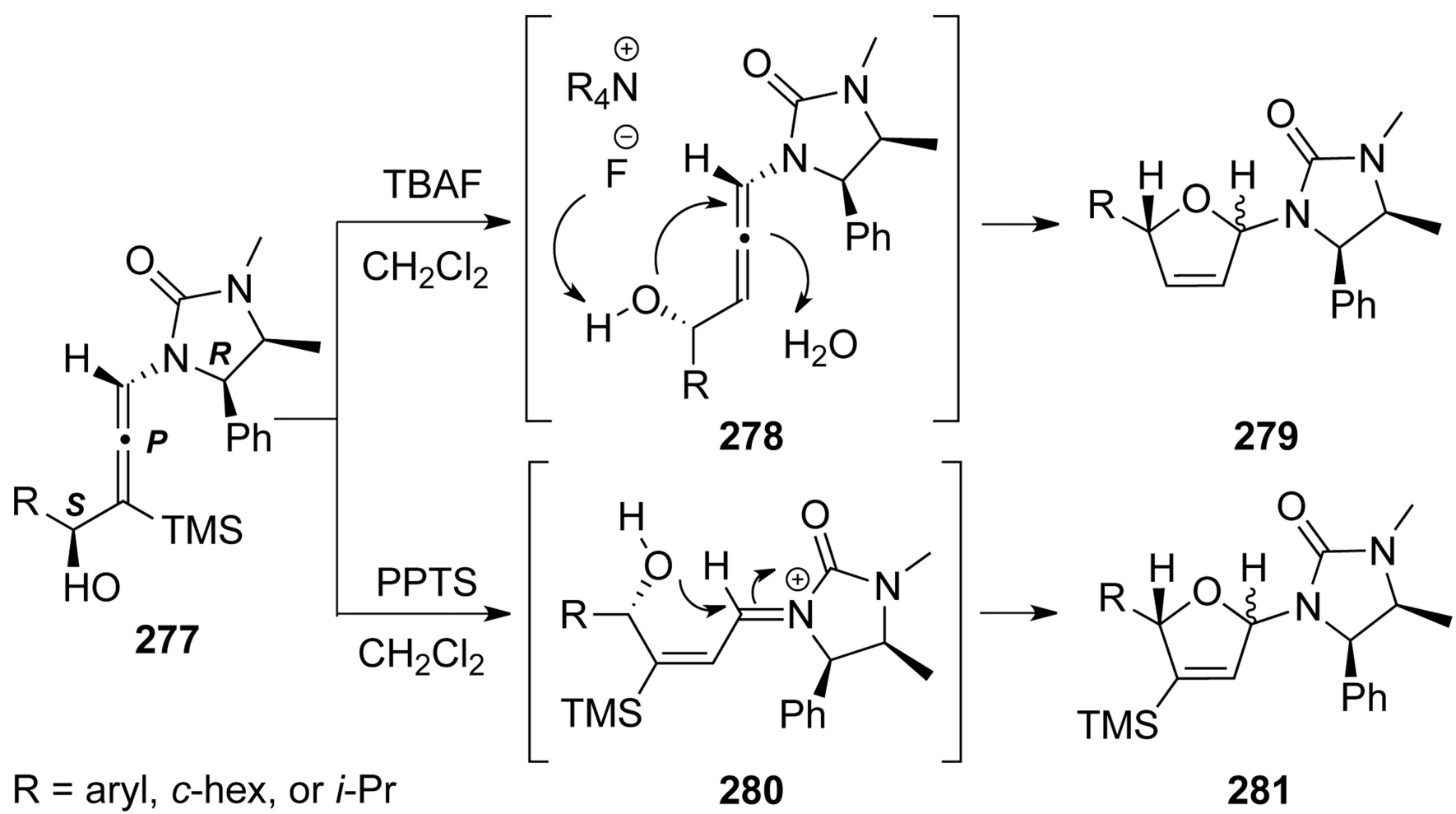

Scheme 77. 
<smiles>[R]C(=O)N(C)C=C=C</smiles>

282<smiles>[R]C(=O)[N+]([O-])=C(C)C=C</smiles><smiles>[R]C(=O)N(C)C(C=C)c1cc(OC)c(OC)cc1CC</smiles>

284

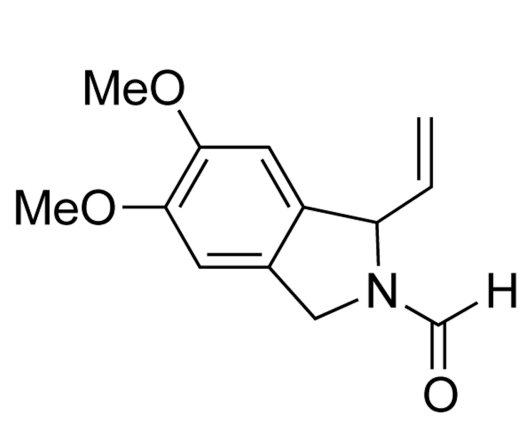

284a: $22 \%$

Scheme 78.<smiles>C=CC1c2cc(OC)c(OC)cc2CCN1C=O</smiles>

284b: $67 \%$<smiles>C=CC1c2cc(OC)c(OC)cc2CCN1C(=O)c1ccccc1I</smiles>

284c: $78 \%$ 


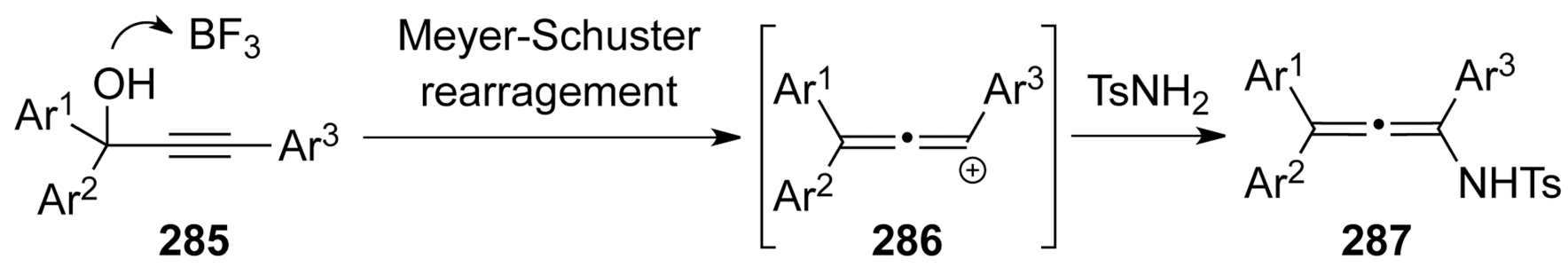

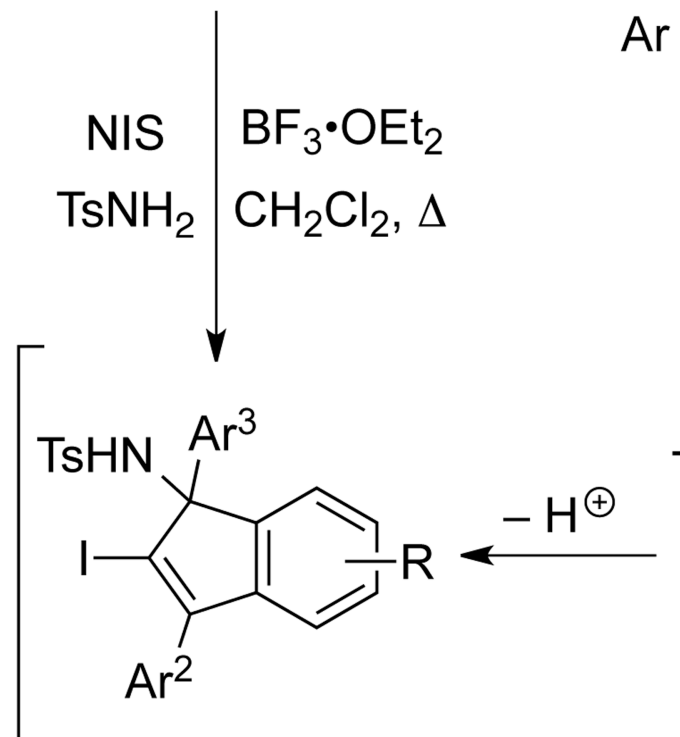

290: $44 \%-77 \%$
$\mathrm{Ar}=\operatorname{aryl} ; \mathrm{R}=\mathrm{H}$, alkyl, alkoxyl, or halo

Scheme 79.

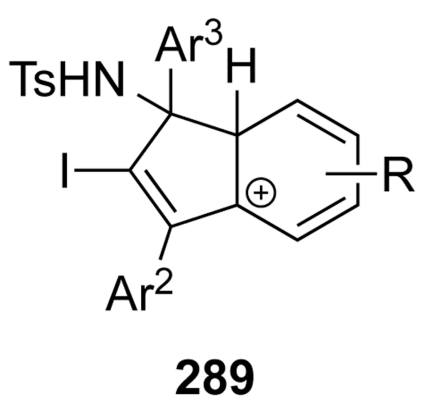<smiles>[R]c1ccccc1I</smiles> 


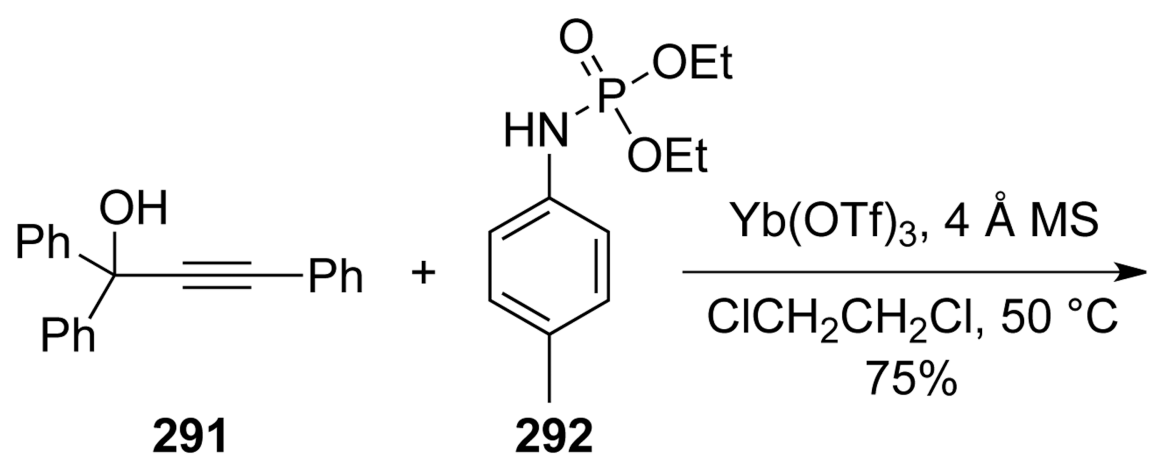<smiles>CCOP(=O)(OCC)N(C(=C=C(c1ccccc1)c1ccccc1)c1ccccc1)c1ccc(C)cc1</smiles>
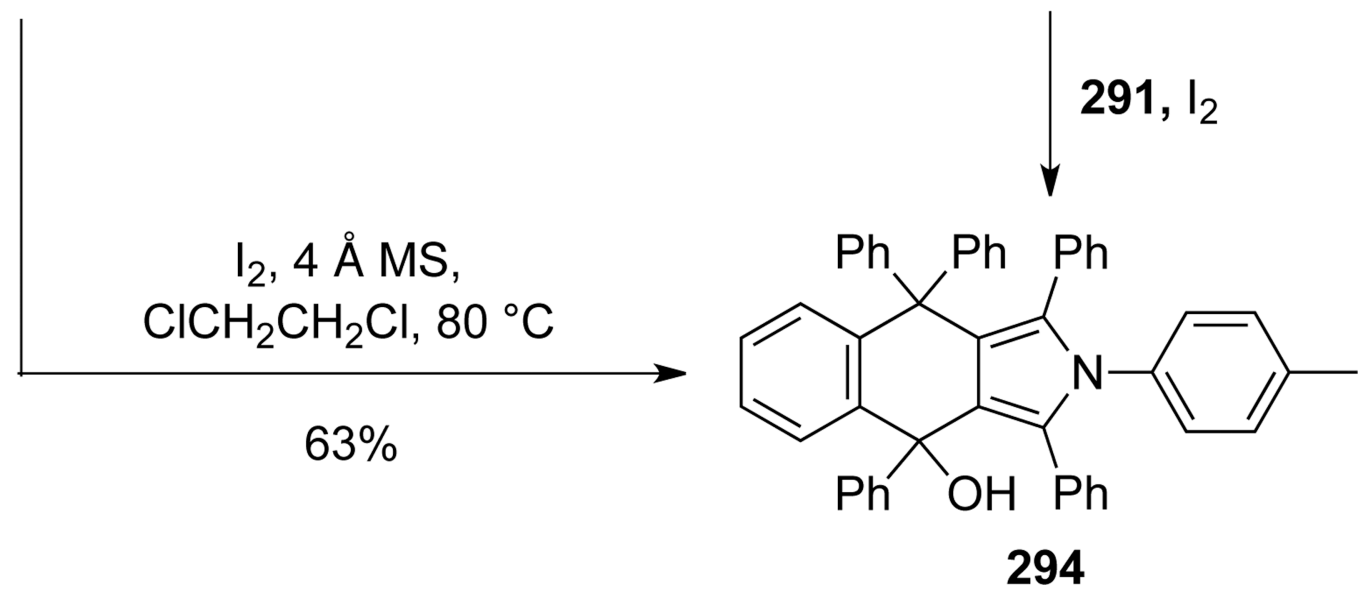

Scheme 80. 


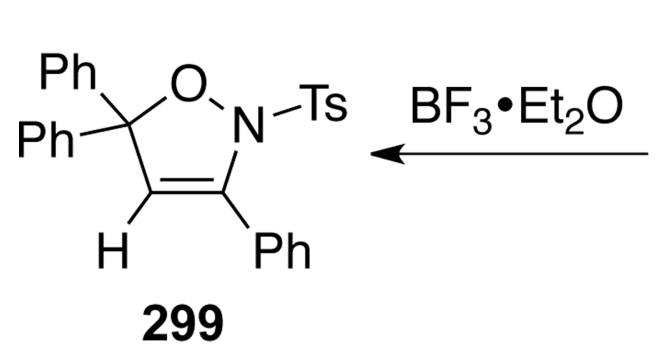

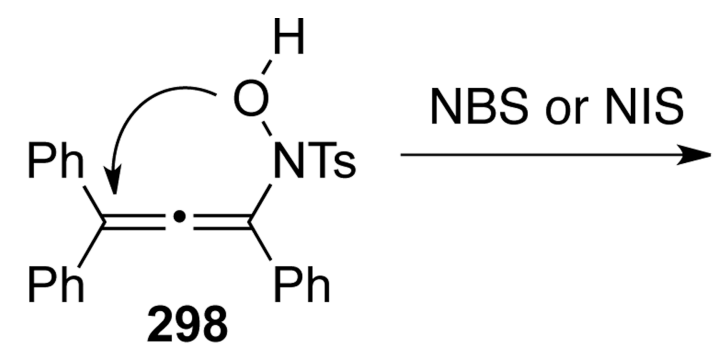<smiles>[X]C1=C(P)N([Al-])OC1(c1ccccc1)c1ccccc1</smiles><smiles>CC#CC(I)(I)OCCC(C#CP)(c1ccccc1)c1ccccc1</smiles>

291

$\uparrow \mathrm{TsNHOH}$<smiles>CC(C)=C=C(C)P</smiles>

295

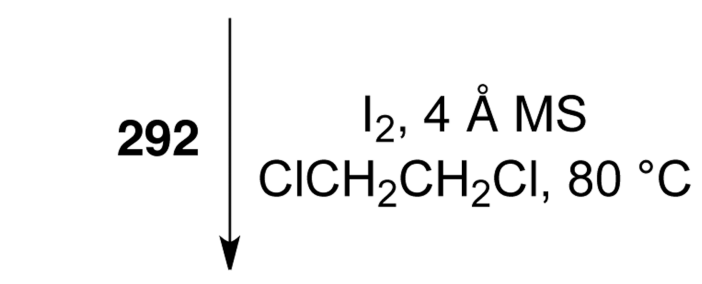<smiles>C[C@H](CO)n1c(-c2ccccc2)c2c(c1-c1ccccc1)C([18OH])(c1ccccc1)c1ccccc1C2(O)c1ccccc1</smiles>

294

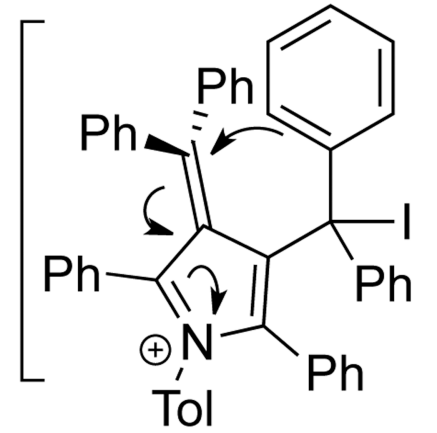

297<smiles>CCOP(=O)(OCC)N([Al])C(=C=C(c1ccccc1)c1ccccc1)c1ccccc1</smiles><smiles>CCCOC(=CC(=[Sb])c1ccccc1)c1ccccc1</smiles>

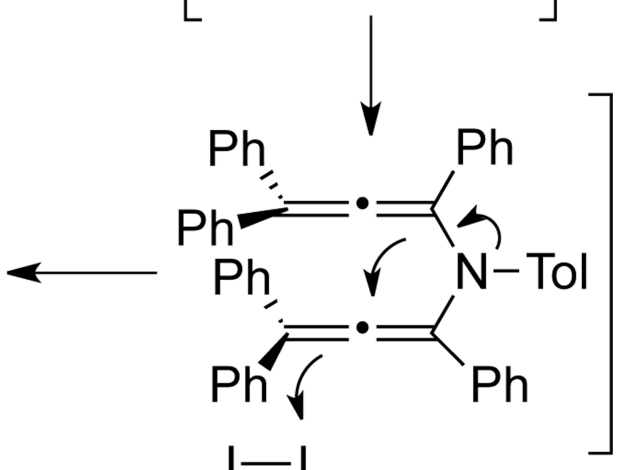
$1-1$

Scheme 81 . 


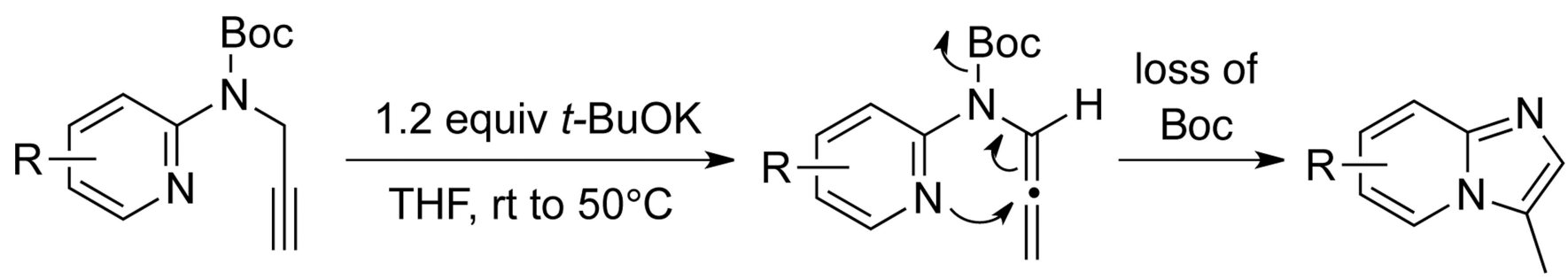

301

302

303<smiles>Cc1cccn2c(C)cnc12</smiles>

303a: $53 \%$<smiles>Cc1cc(I)cn2c(C)cnc12</smiles>

303d: 58\%

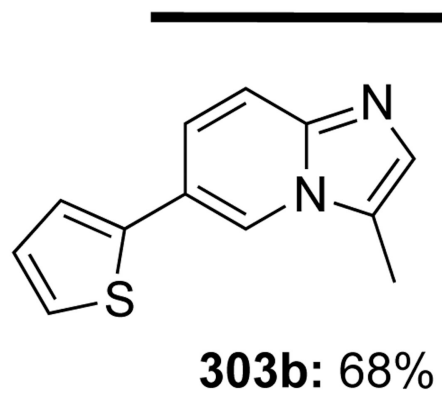<smiles>Cc1cnc2ccc(C#Cc3ccccc3)cn12</smiles>

303e: $72 \%$<smiles>Cc1cnc2ccc(-c3cccc(C(F)(F)F)c3)cn12</smiles><smiles>[Z17]OC(=O)/C=C/c1ccc2ncc(C)n2c1</smiles>

303f: $51 \%$ 
$\mathrm{R}^{1} \mathrm{CO}_{2} \mathrm{H} \quad \mathrm{NCR}$

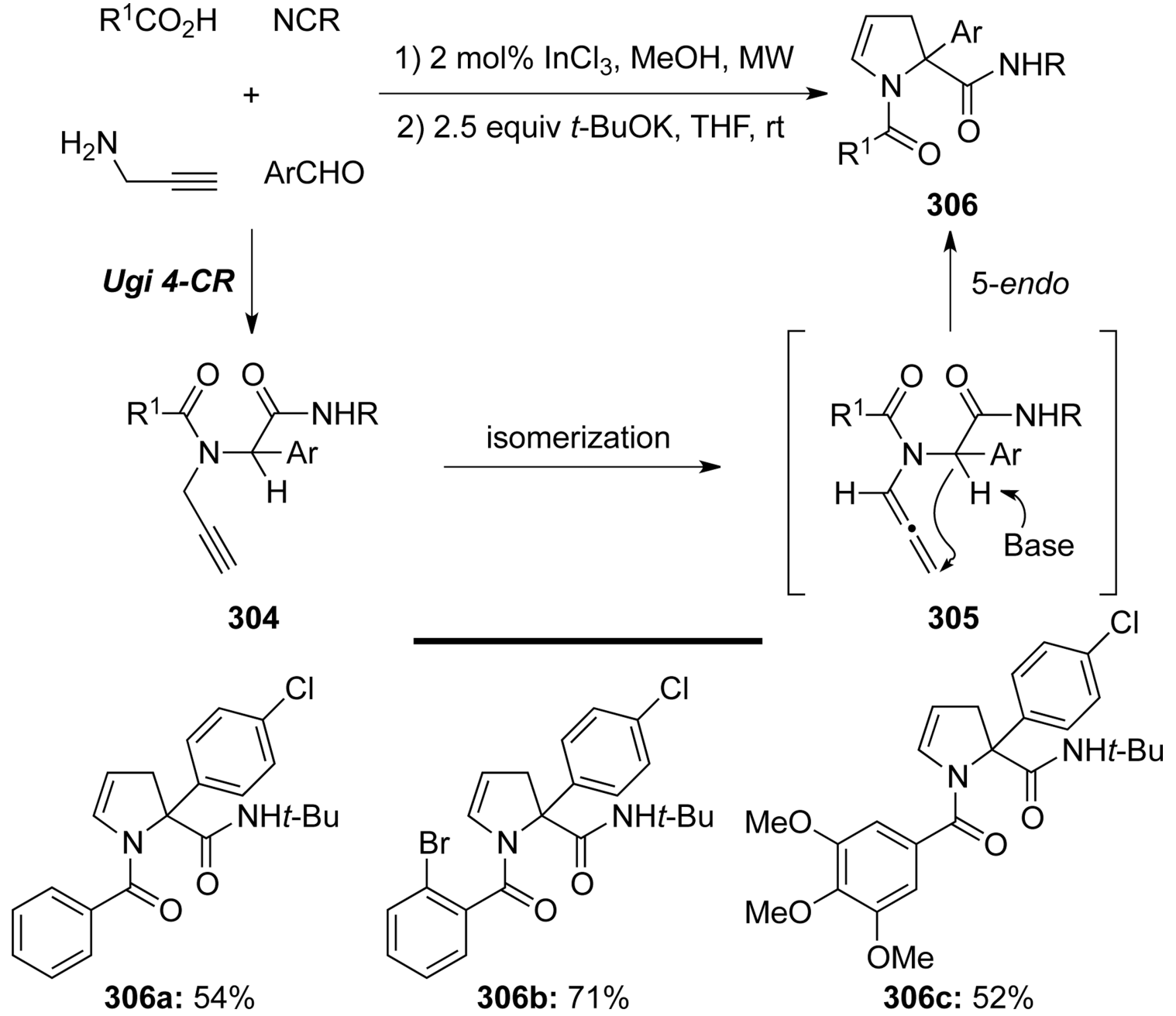<smiles>CCC(C)CNC(=O)C1(c2ccc(F)cc2)CC=CN1C(=O)c1ccccc1</smiles><smiles>CC(C)CNC(=O)C1(c2ccccc2)CC=CN1C(=O)c1ccccc1</smiles>

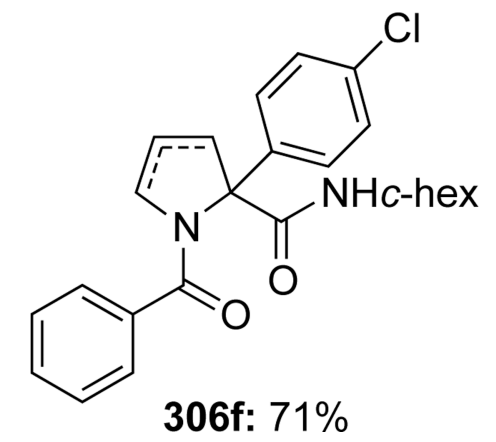

Scheme 83. 

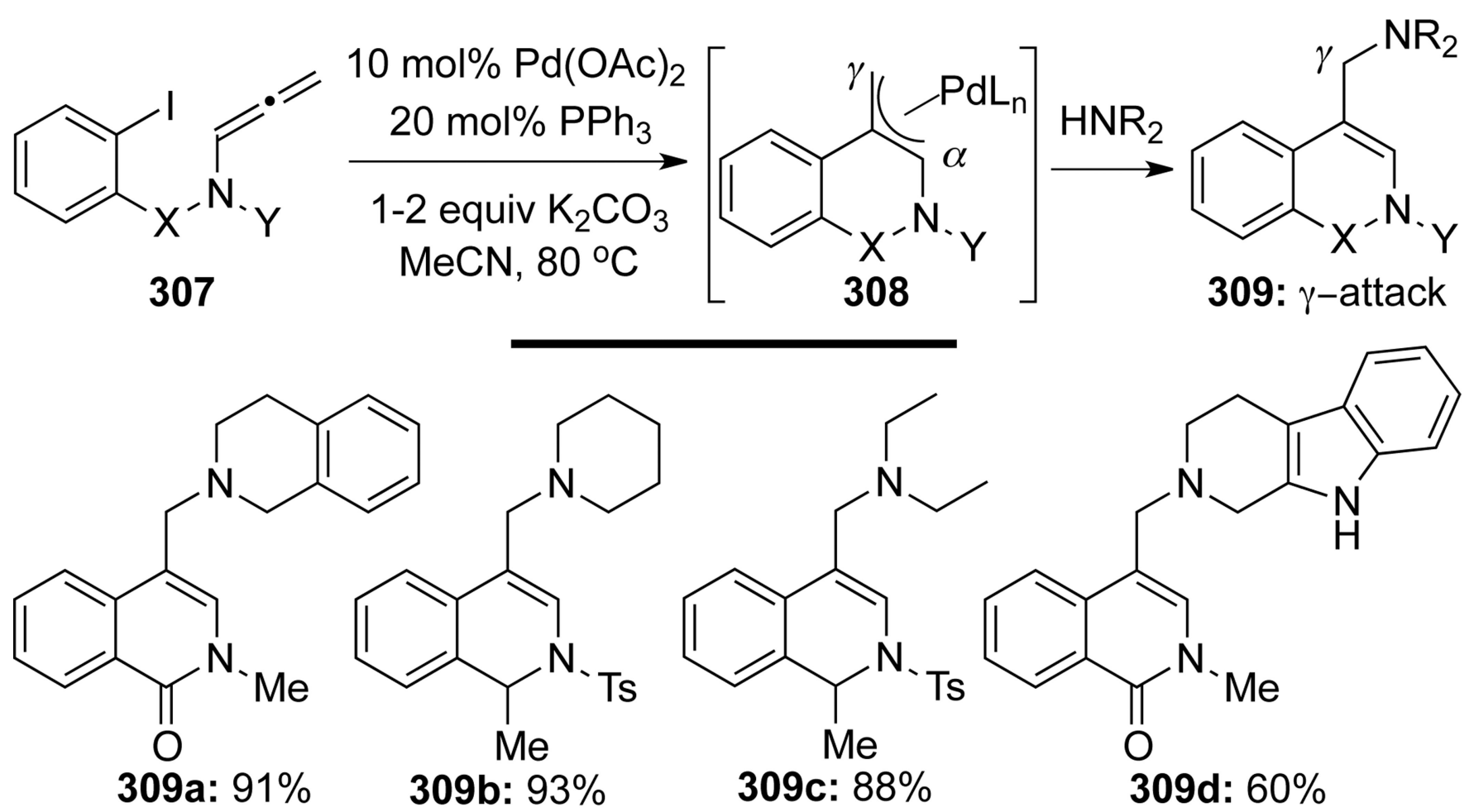

309b: $93 \%$

309c: $88 \%$

309d: $60 \%$<smiles>C=C1c2ccccc2C(=O)N(C)C1N1CCc2ccccc2C1</smiles>

309a': $\alpha$-attack [77\%]

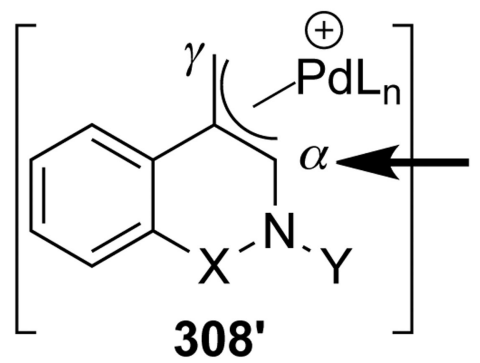

Scheme 84. 
<smiles>[X]c1ccccc1[Y]N(C=C=C)S(=O)(=O)Oc1ccccc1</smiles>

310: $X=I, B r$

\section{1 equiv $n-\mathrm{Bu}_{3} \mathrm{SnH}$} $10 \mathrm{~mol} \% \mathrm{Pd}(\mathrm{OAc})_{2}$ $20 \mathrm{~mol}_{0} \mathrm{PPh}_{3}$ $0{ }^{\circ} \mathrm{C}, \mathrm{THF}$<smiles>[X]c1ccccc1[X]</smiles>
311: $\mathrm{R}=n-\mathrm{Bu}_{3} \mathrm{Sn}$<smiles>C=CC1c2ccccc2[Y]N1S(=O)(=O)O</smiles>

314<smiles>[R]CC(P)C1c2ccccc2[Y]N1S(=O)(=O)Oc1ccccc1</smiles>

313: $\mathrm{R}=n-\mathrm{Bu}_{3} \mathrm{Sn}$

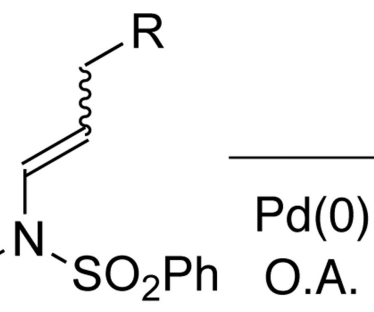

O.A.

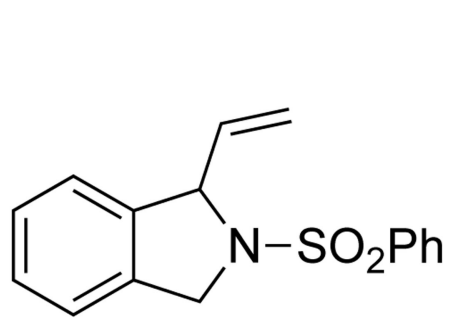

314a: $66 \%$<smiles>C=CC1c2ccccc2CCN1S(=O)(=O)c1ccccc1</smiles>

314b: $52 \%$<smiles>C=CC1c2ccccc2OCCN1S(=O)(=O)c1ccccc1</smiles>

314c: $50 \%$<smiles>C=CC1c2ccccc2COC1(O)OS(=O)(=O)c1ccccc1</smiles>

314d-h: $n=5-11[40 \%-46 \%]$<smiles>[R]CC=C1[Te][Te]([Y])c2ccccc2[Y]1N([Y])S(=O)(=O)Oc1ccccc1</smiles>

312: $\mathrm{R}=n-\mathrm{Bu}_{3} \mathrm{Sn}$

Scheme 85. 
<smiles>CC#CCN(c1ccccc1I)C(C)(C)C</smiles><smiles>[R]NCC#CCC</smiles>
315<smiles>[R2]N[C@H]1C=C2c3ccccc3N([CH])[C@H]2[C@H]2C(=O)N(C)C(=O)[C@H]12</smiles>

319a: $R=$ Et [56\% from 315a] 319b: $R_{2}=\left(\mathrm{CH}_{2}\right)_{4}[60 \%$ from 315b]

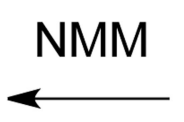

$10 \mathrm{~mol} \% \mathrm{Pd}(\mathrm{OAc})_{2}$

sodium formate $\mathrm{TI}_{2} \mathrm{CO}_{3}$

MeCN, reflux<smiles>[Y20]CC([Y9])c1c(C)n([Y6])c2ccccc12</smiles>

317

316<smiles>[R2]N/C=C/c1c([2H])n(C)c2ccccc12</smiles>

318

not isolated

1) $10 \mathrm{~mol} \% \mathrm{Pd}(\mathrm{OAc})_{2}$<smiles>[R2]CC#CCN(C)C(=O)c1ccccc1I</smiles>
$20 \mathrm{mo}_{0} \mathrm{PPh}_{3}$ sodium formate, $\mathrm{Tl}_{2} \mathrm{CO}_{3}$ MeCN, reflux

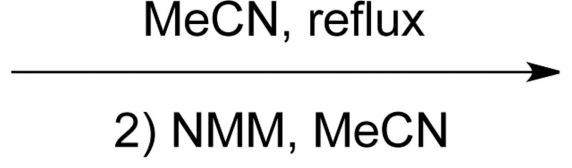<smiles>[R20]C1C=C2c3ccccc3C(=O)N(C)C2[C@@H]2C(=O)N(C)C(=O)[C@@H]12</smiles>

321a: $\mathrm{R}_{2}=\left(\mathrm{CH}_{2}\right)_{5}[70 \%]$ 321b: $\mathrm{R}_{2}=\left(\mathrm{CH}_{2}\right)_{4}$ [62\%] 321c: $R=$ Et [64\%] 


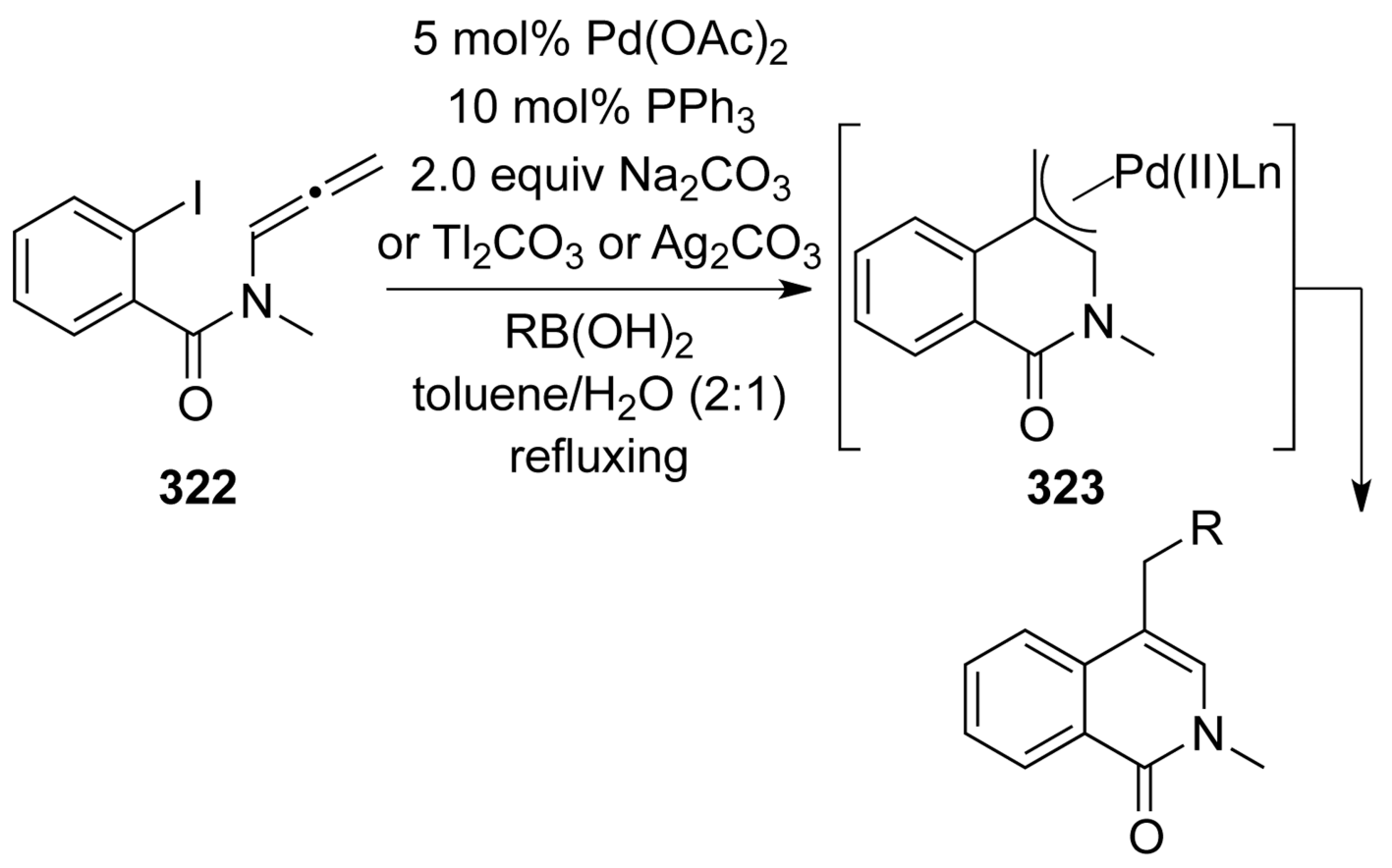

324: major<smiles>[R]C1C(=C)c2ccccc2C(=O)N1C</smiles>

325: minor

324a: $\mathrm{R}=\mathrm{Ph}[61 \%]$

324b: $R=-\{\}$

324c: $\mathrm{R}=\mathrm{s}^{\mathrm{s}}=\mathrm{Ph}[54 \%]$

Scheme 87. 

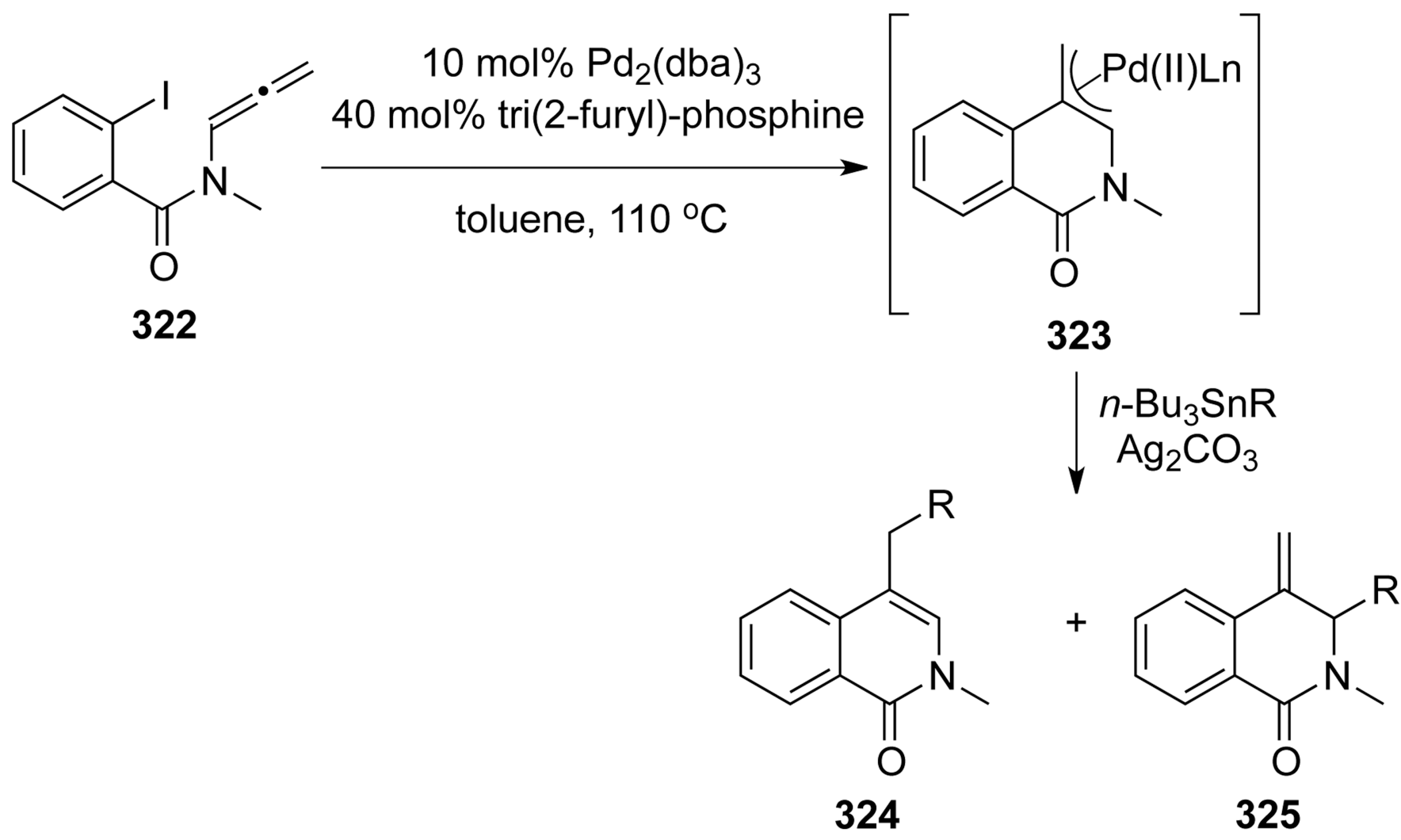

324d/325d: $R=$ 2-furyl [70\% (6:1)] 324e/325e: $\mathrm{R}=\mathrm{CH}=\mathrm{CH}_{2}[60 \%(1: 1)]$

Scheme 88 . 

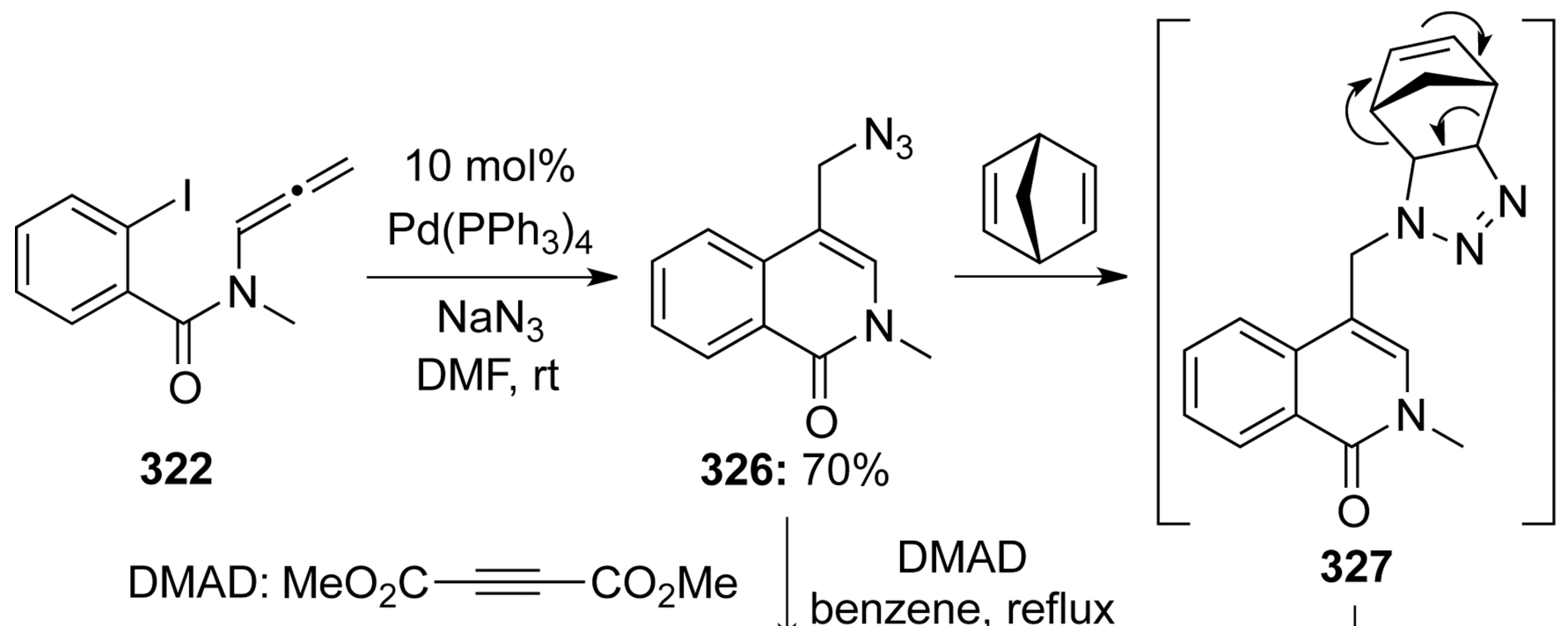

DMAD<smiles>COC(=O)c1nnn(C)c1C(=O)OC</smiles>
benzene, reflux

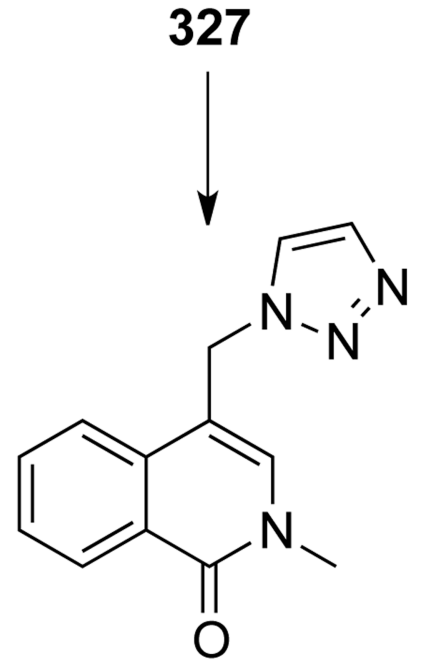<smiles>C=NNCc1cn(C)c(=O)c2ccccc12</smiles>

328: $85 \%$

Scheme 89. 


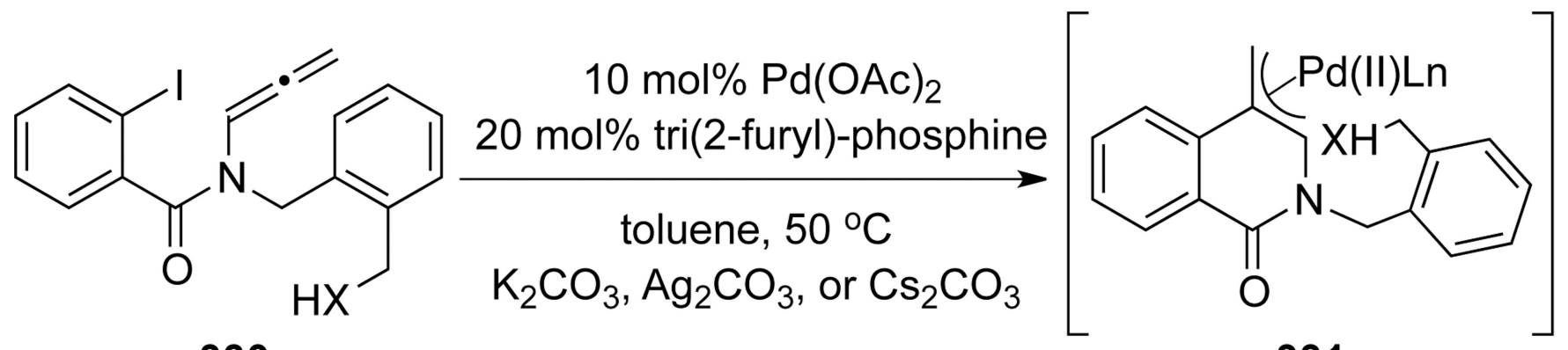

330<smiles>C=C1c2ccccc2C(=O)N2Cc3ccccc3CN(C(C)c3cccc4ccccc34)C12</smiles>

332a: $54 \%$<smiles>C=C1c2ccccc2C(=O)N2Cc3ccccc3CN(Cc3ccccc3)C12</smiles>

332b: $63 \%$<smiles>C=C1c2ccccc2C(=O)N2Cc3ccccc3COC12</smiles>

332c: $50 \%$

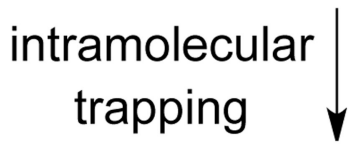<smiles>[X]Cc1ccccc1CN1C(=O)c2ccccc2C(=C)C1[X]</smiles>

332<smiles>[R]C1([R])Cc2ccccc2CN2C(=O)c3ccccc3C(=C)C21</smiles>

332d: $\mathrm{R}=\mathrm{CO}_{2} \mathrm{Me}[45 \%]$

Scheme 90. 
<smiles>[X]C=C=C</smiles>

333<smiles>CCOC(=O)/C=N/[Sb]([O])(=O)C(C)(C)C</smiles>

S-334<smiles>[R]C(NS(C)([O-])[O-])C1C(=C)c2ccccc2N1S(=O)(=O)O</smiles>

336a: $44 \%$
Scheme 91.
1 equiv In, 10 mol\% $\mathrm{Pd}(\mathrm{OAc})_{2}$ 20 mol\% tri-2-furylphosphine

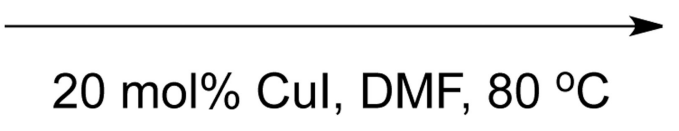

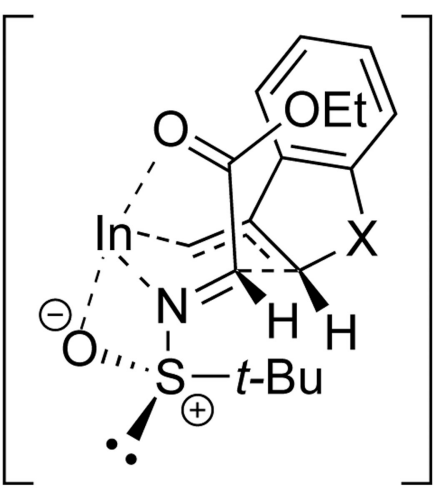

335<smiles>[R]C(N[Sb]([O-])([O-])CC(C)(C)C)[C@H]1C(=C)c2ccccc2C(=O)N1C</smiles>

336b: $28 \%$

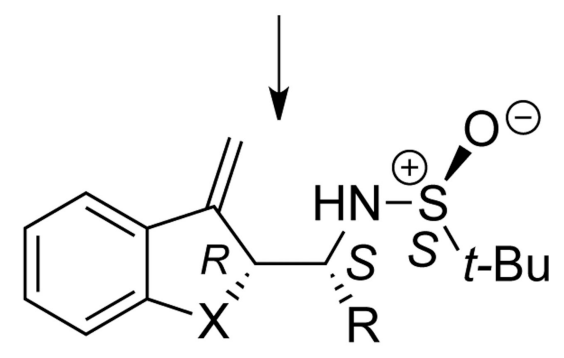

336: $\mathrm{R}=\mathrm{CO}_{2} \mathrm{Et}$ 


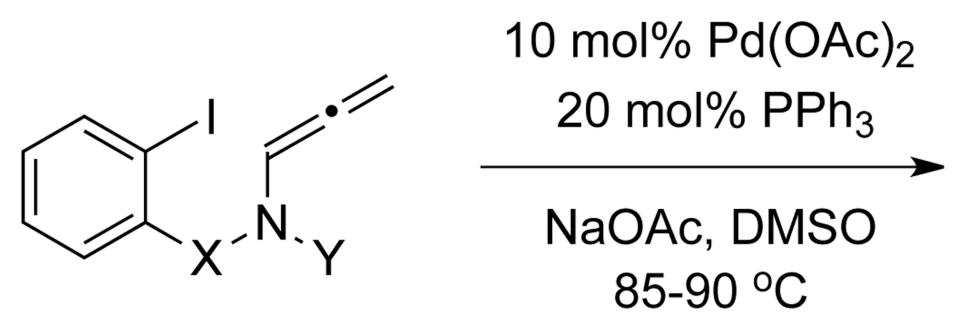

337

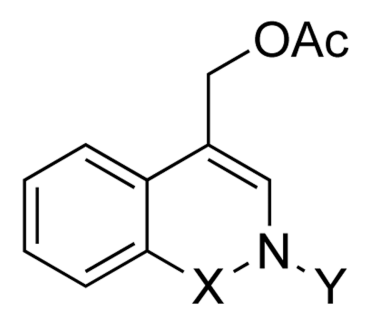

338<smiles>COCc1cn([As])c2ccccc12</smiles>

338a: $52 \%$<smiles>Cn1cc(COC(C)(C)C)c2ccccc2c1=O</smiles>

338b: $46 \%$

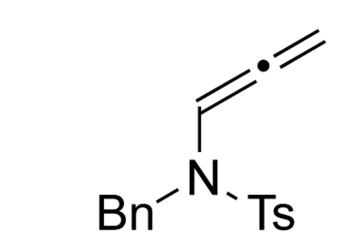

337c<smiles>COc1ccc(I)cc1</smiles>

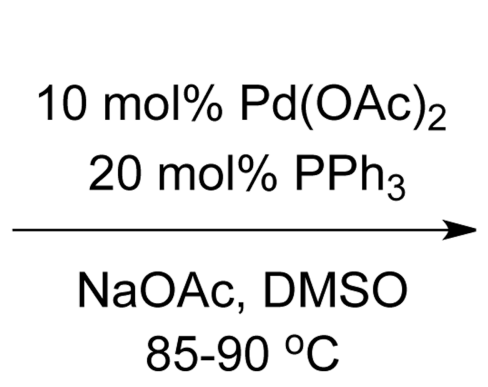

Scheme 92.

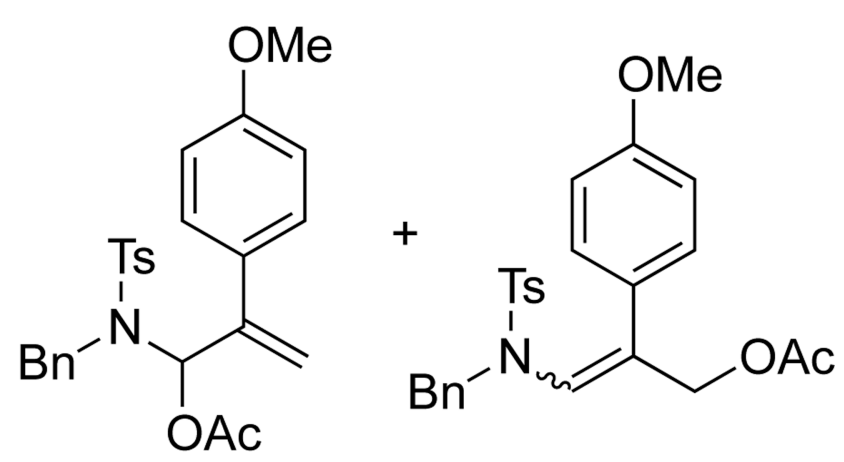

339: $29 \%$ 


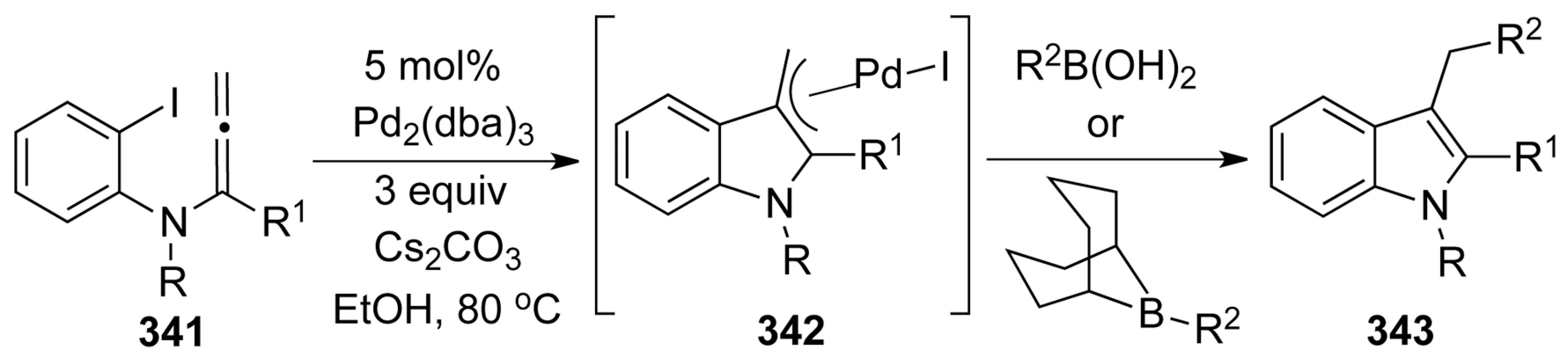<smiles>[R]n1cc(Cc2ccccc2)c2ccccc21</smiles><smiles>CCOC(C)Cc1cn(C)c2ccccc12</smiles>

343a: $R=T s$ [88\%]

343c: $82 \%$<smiles>[R]c1c(Cc2ccccc2)c2ccccc2n1[R6]</smiles>

343b: $R=$ Boc [98\%]

343d: $\mathrm{R}^{1}=\mathrm{Bn}[98 \%]$<smiles>[R6]n1c([Si](C)(C)O)c(Cc2ccccc2)c2ccccc21</smiles>

Scheme 93. 


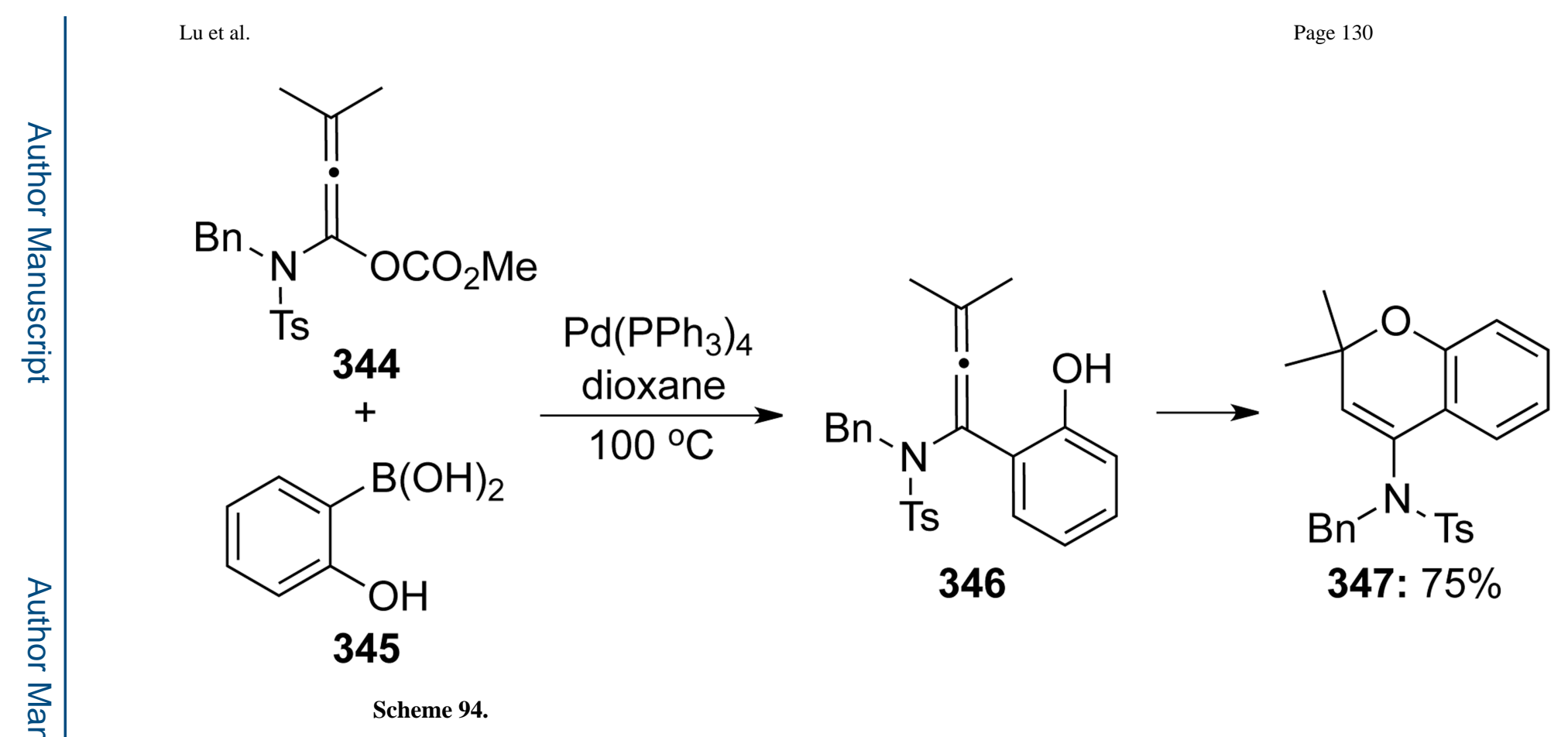


<smiles>[Y]C(C)c1ccccc1I</smiles>

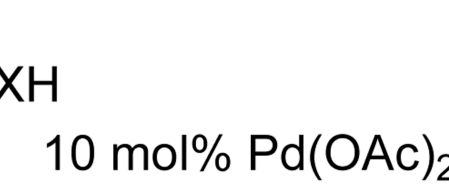

348

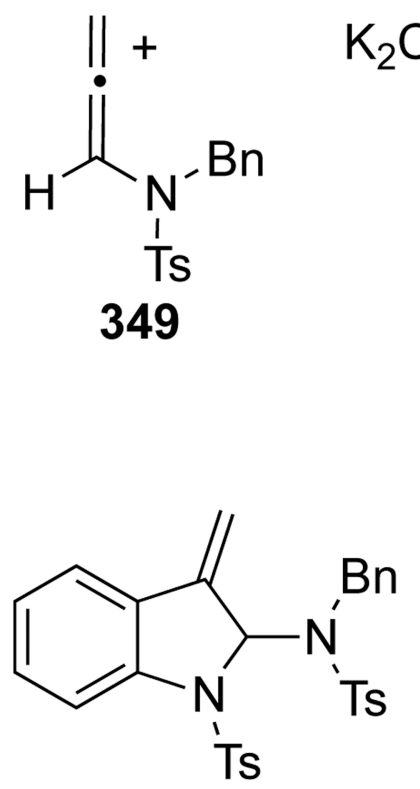<smiles>C=C(C)c1ccccc1C(C)(C)C</smiles>

354a: $81 \%$<smiles>C=C1c2ccccc2COC1N([As])Cc1ccccc1</smiles>

354b: $99 \%$

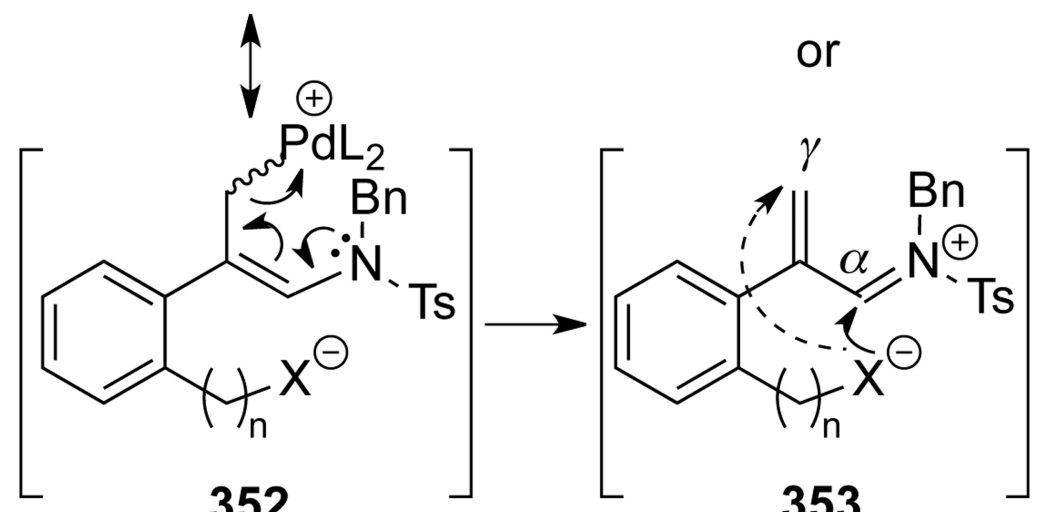

352<smiles>[X]C(C(=C)c1ccccc1C(C)(C)C)N(Cc1ccccc1)C(F)(F)F</smiles>

354

Scheme 95. 


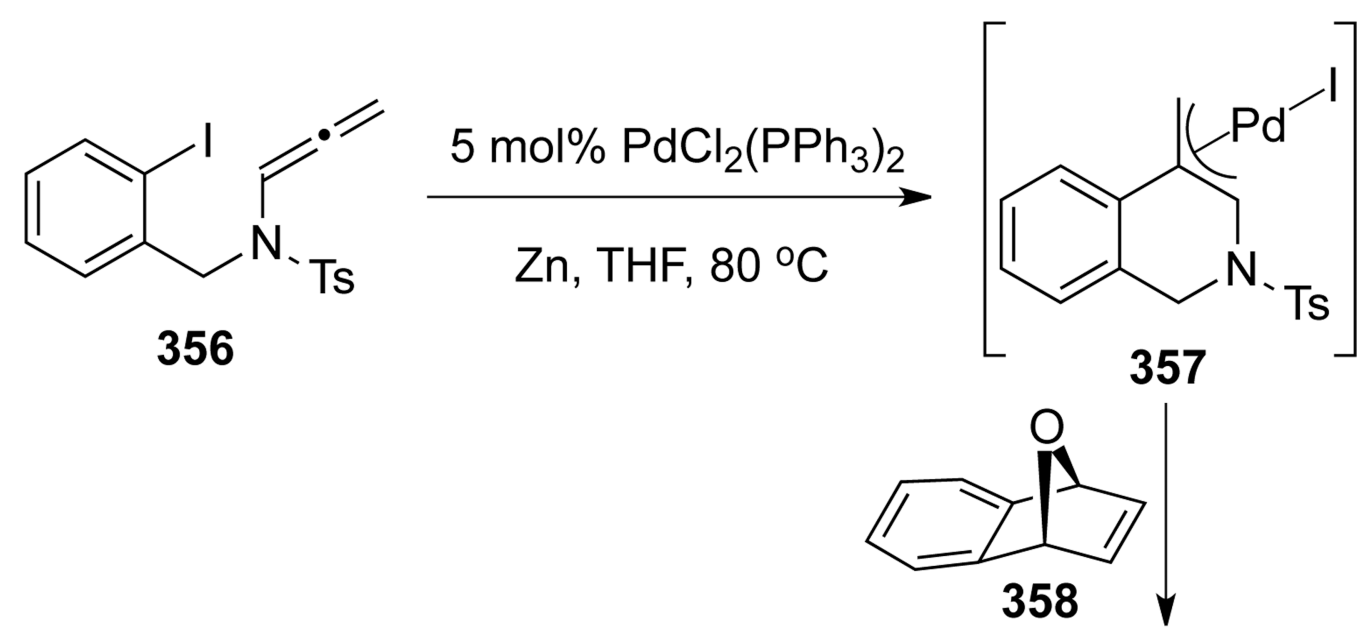

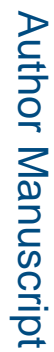
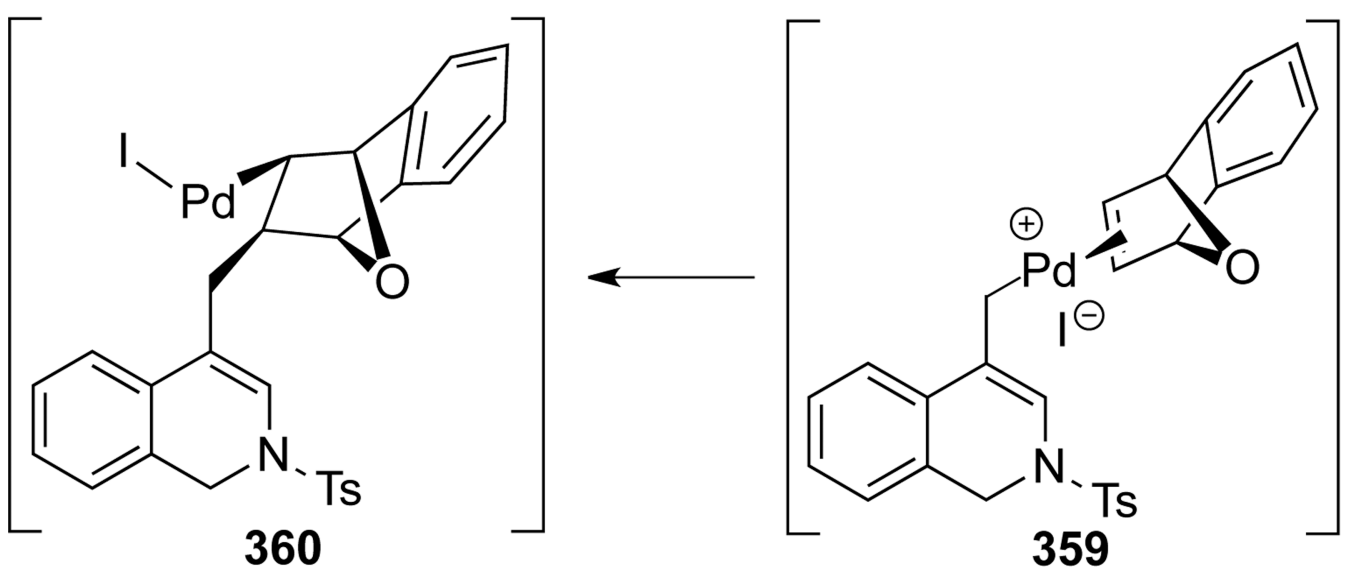

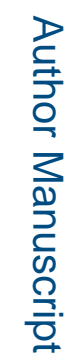<smiles>CN1C=C(C[C@@H]2C=Cc3ccccc3[C@@H]2OPI)c2ccccc2C1</smiles>

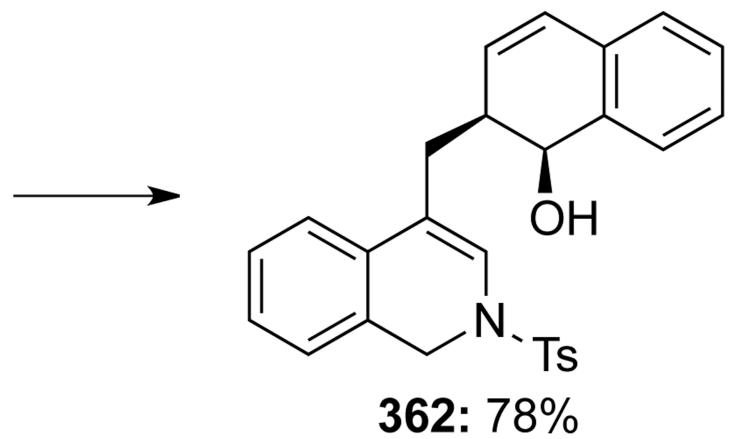

Scheme 96. 


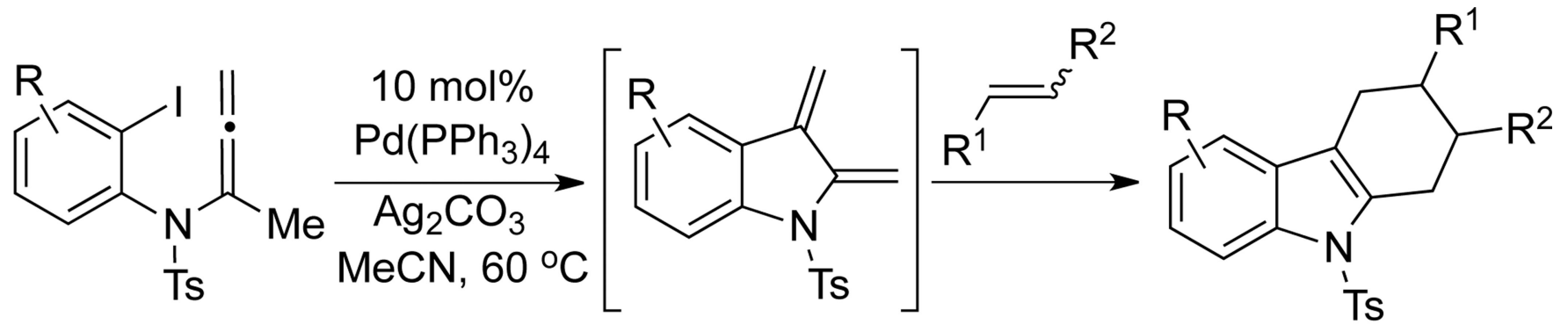<smiles></smiles>

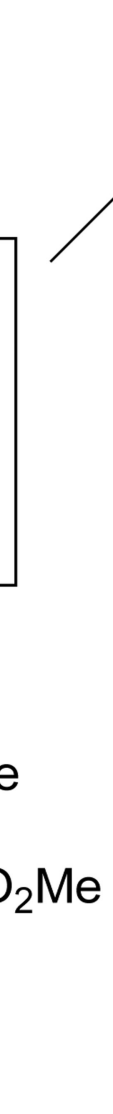

365a: $81 \%$

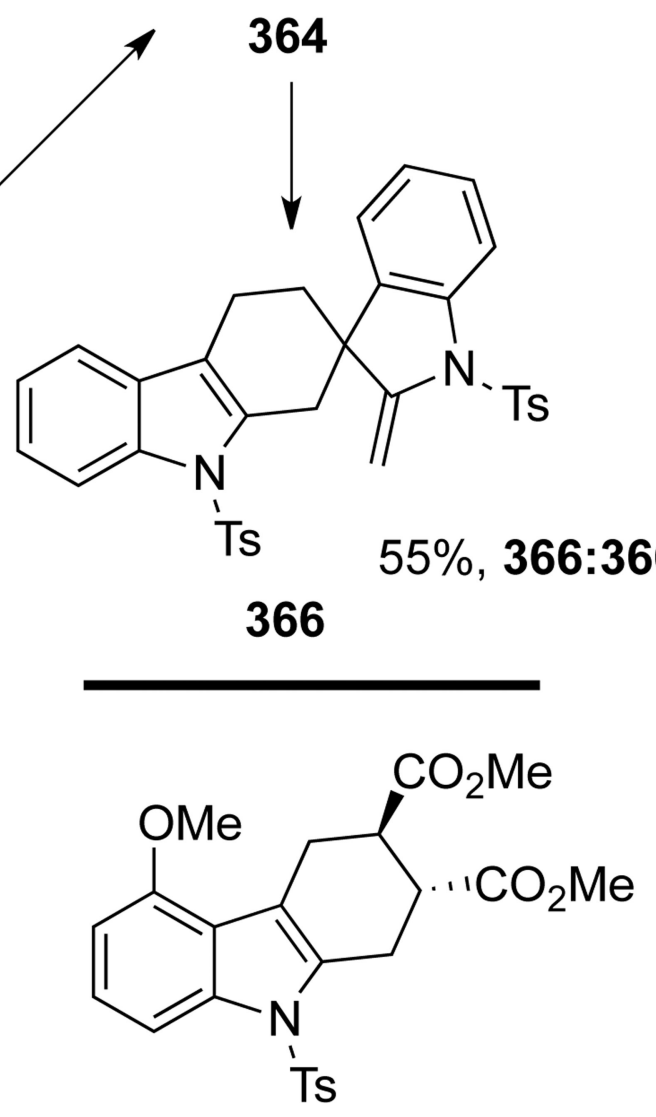

365b: $87 \%$

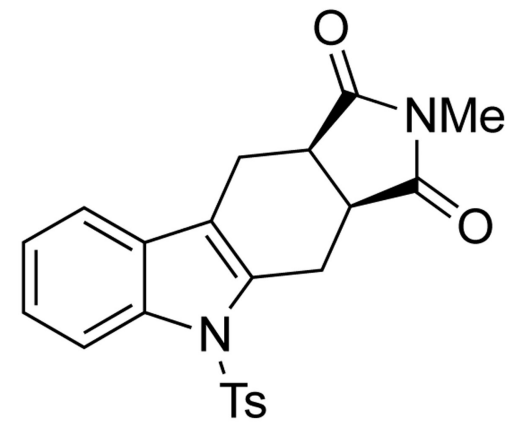

365c: $93 \%$ 

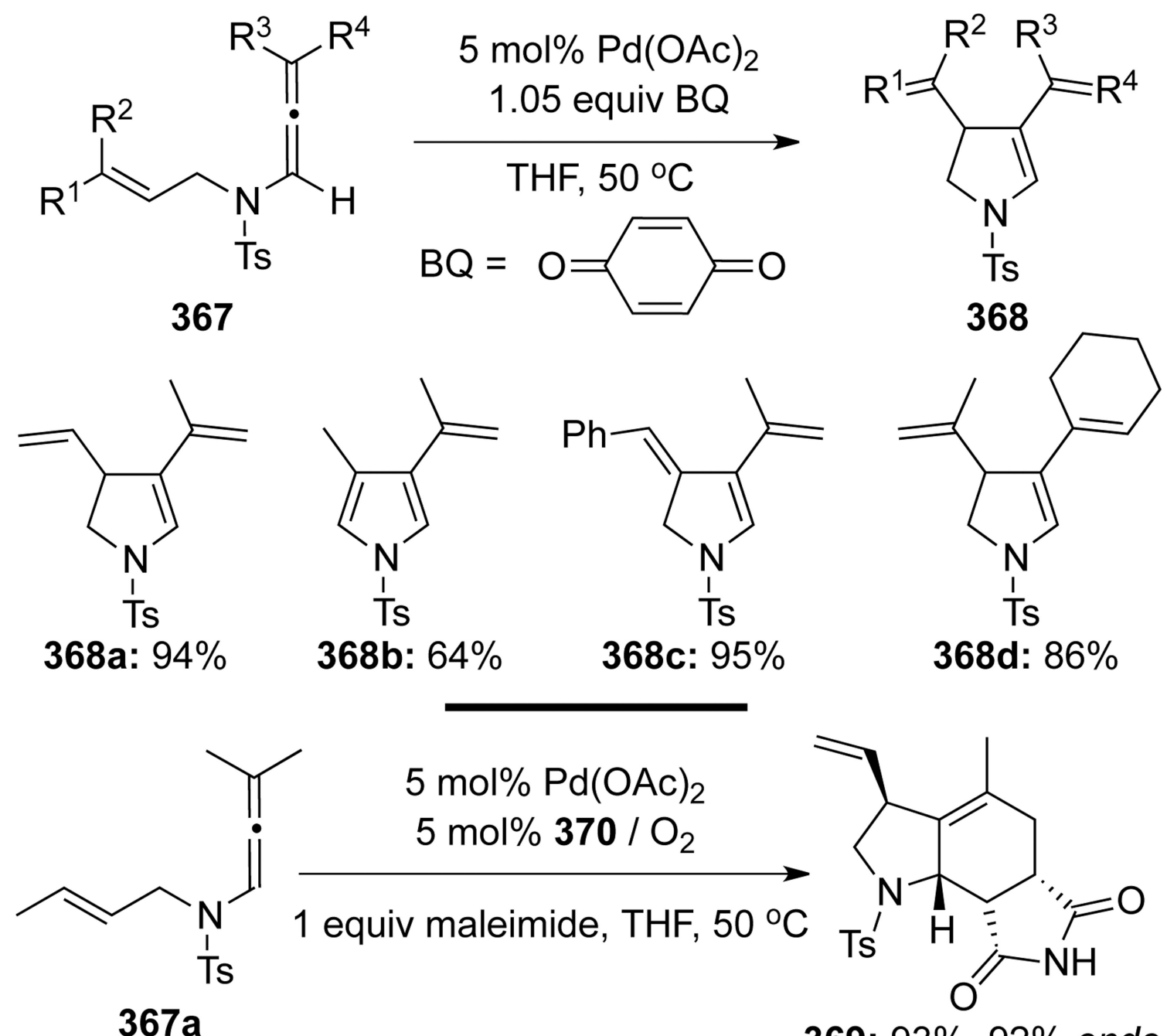
$367 a$

369: $93 \%, 92 \%$ endo<smiles>CCC=C1C=CC(=O)N1</smiles>

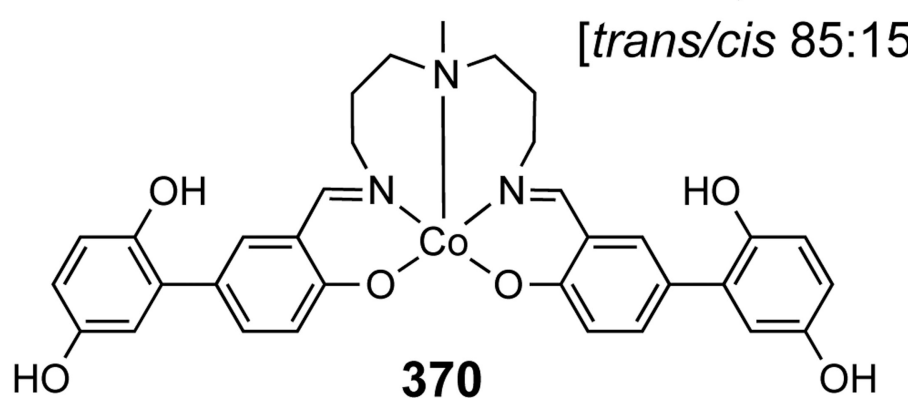

Scheme 98. 
<smiles>[R2]C#CC(C)C1COC(=O)N1C=C=C([R7])C</smiles>
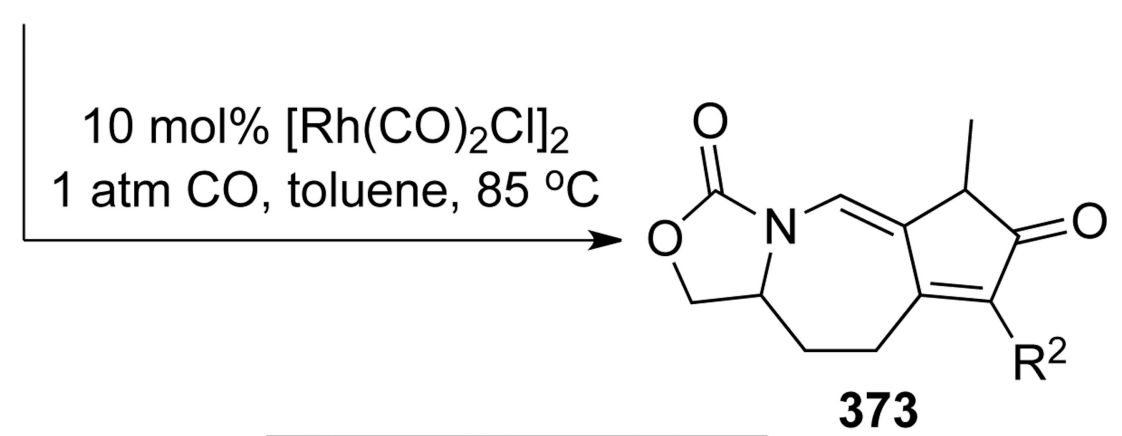<smiles>C=C(C)C1=CN2C(=O)OCC2/C1=C\C</smiles><smiles>C=C(C)C1=CN2C(=O)OCC2C/C1=C/C</smiles>

$\mathrm{R}^{2}$

372a: $72 \%$

372b: $R^{2}=$ TMS [95\%]

372c: $\mathrm{R}^{2}=4-\mathrm{MeOC}_{6} \mathrm{H}_{4}[87 \%]$

372d: $R^{2}=$ TMS [90\%]<smiles>C=CC1=CN2C(=O)OCC2CC1=CC</smiles>

$\mathrm{R}^{2}$

372e: $\mathrm{R}^{2}=4-\mathrm{MeOC}_{6} \mathrm{H}_{4}[73 \%]$<smiles>C=C(C(C)=O)C1=CN2C(=O)OCC2C/C1=C\CC</smiles>

372f: $85 \%$<smiles>[R2]C1=C2CCC3COC(=O)N3C=C2C(C)C1=O</smiles>

373a: $\mathrm{R}^{2}=i-\operatorname{Pr}[75 \%, d r 3: 1]$ 373b: $\mathrm{R}^{2}=\mathrm{TMS}[89 \%, d r$ 3:1] 373c: $\mathrm{R}^{2}=\mathrm{Ph}[75 \%, d r 3.6: 1]$ 


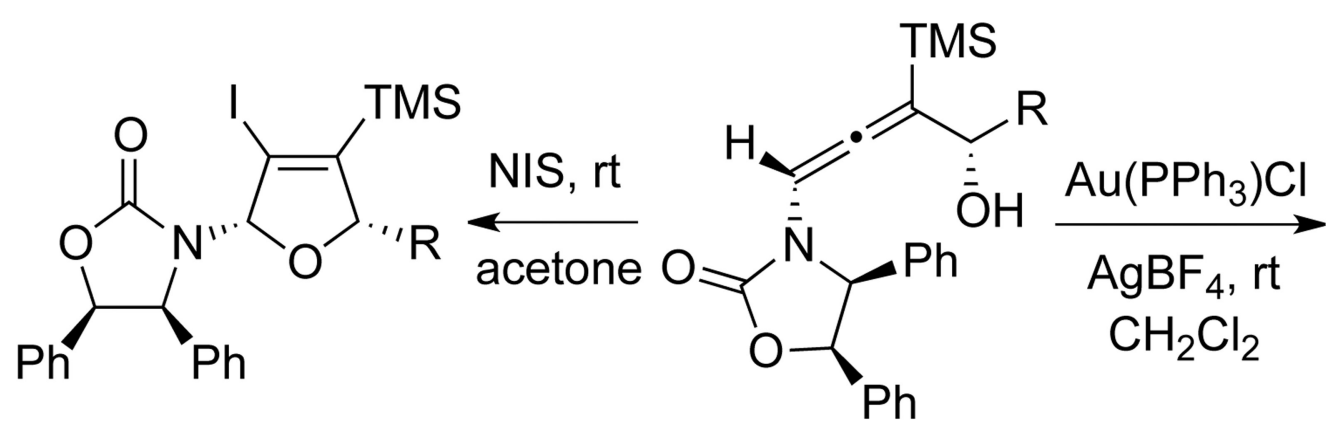

375a: $\mathrm{R}=\mathrm{Ph}[99 \%]$

375b: $\mathrm{R}=i-\operatorname{Pr}[99 \%]$<smiles>CC(Oc1ccccc1)[C@H]1O[C@@H](N2C(=O)O[C@@H](P)[C@H]2P)C(I)=C1[As]</smiles>

375c: $70 \%$

374

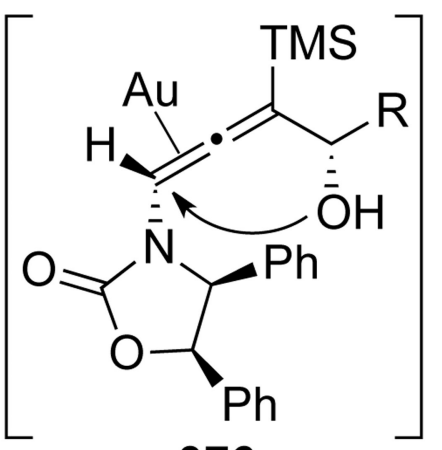

376

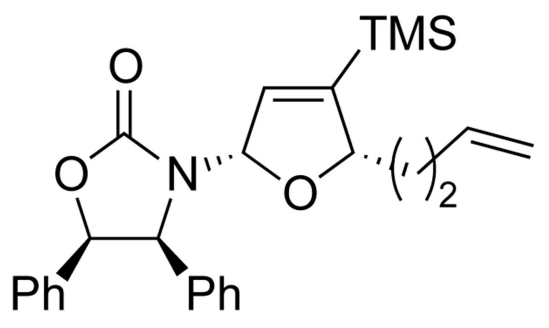

377c: $86 \%$<smiles></smiles>

377a: $\mathrm{R}=\mathrm{Ph}[80 \%]$ 377b: $\mathrm{R}=i-\operatorname{Pr}[87 \%]$

Scheme 100. 


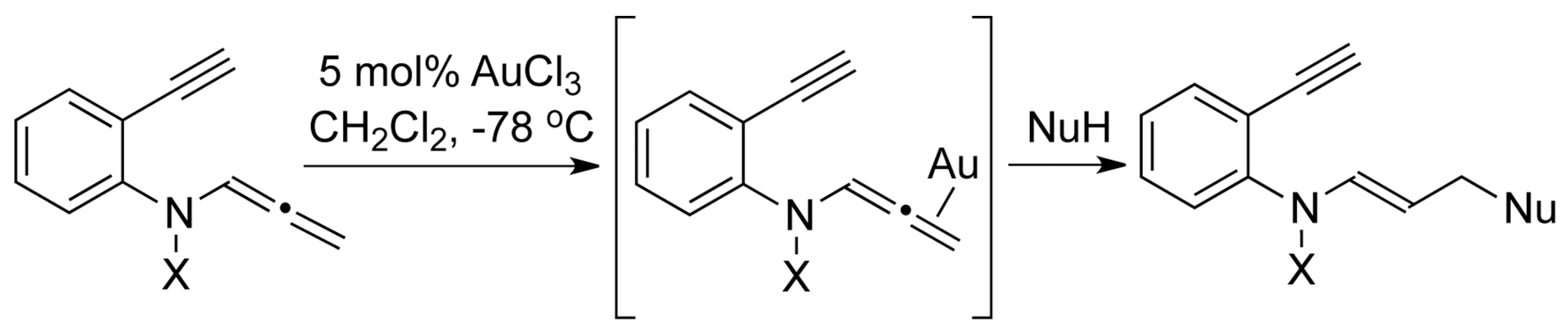

378<smiles>[Y]N1c2ccccc2C=CC(CN)C1[N]</smiles>

383<smiles>CCOCC1C=Cc2ccccc2N([Si])C1OCC</smiles>

383b: $81 \%$<smiles>CCSCC1C=Cc2ccccc2N([Si])C1[Si]C</smiles>

383c: $77 \%$, trans/cis $1: 1$

Scheme 101. 


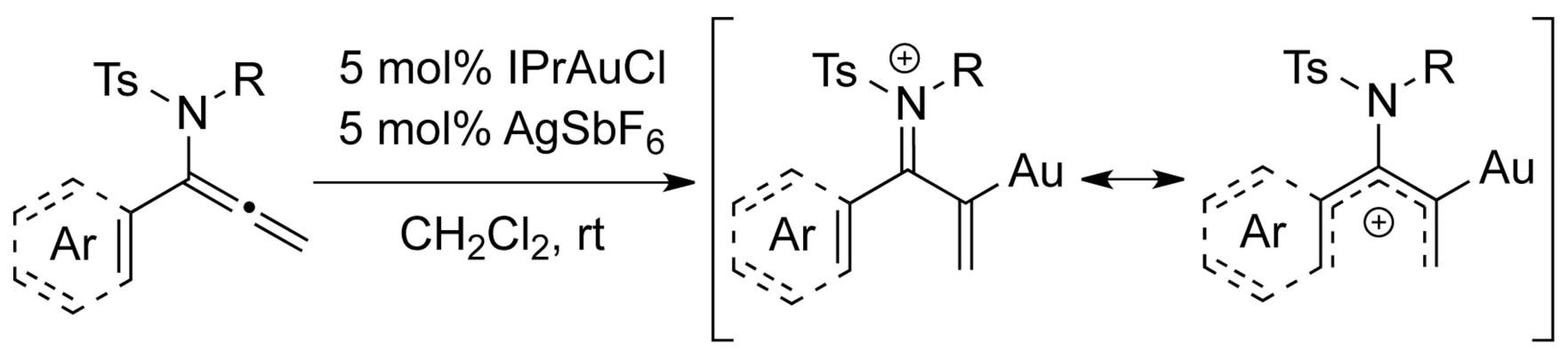

384

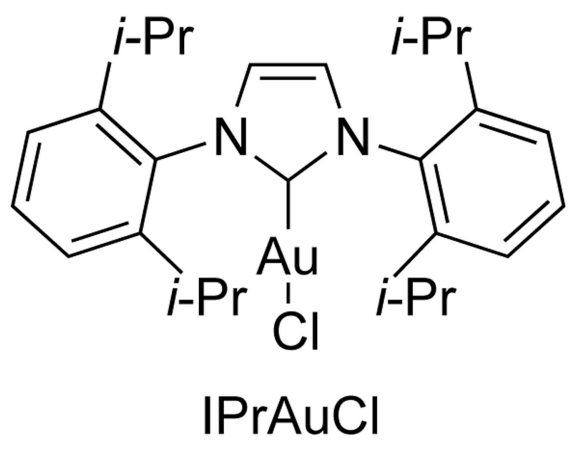

385

\section{ortho selective}

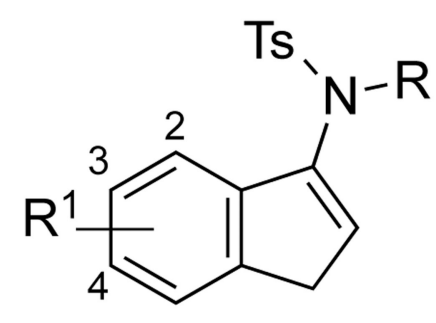

387a: $R=M e, R^{1}=H[93 \%]$

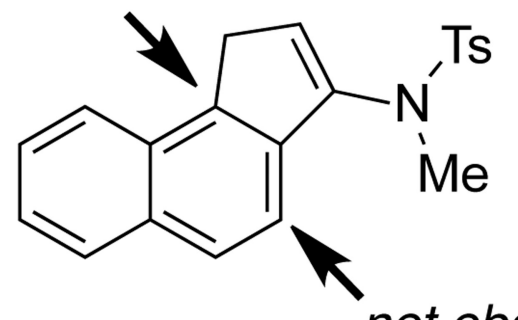

not observed

387e: $97 \%$

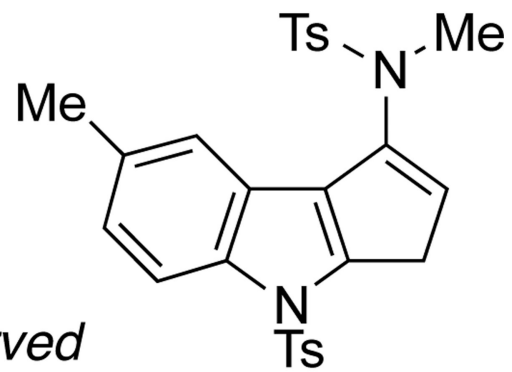

387f: $79 \%$

387b: $R=M e, R^{1}=3-O M e ~[94 \%]$

387c: $R=M e, R^{1}=4-M e[97 \%]$

387d: $R=B u, R^{1}=4-O M e[94 \%]$

Scheme 102. 
<smiles>[R]C(=O)N(C=C=C)CC(C)c1ccccc1I</smiles>
388<smiles>[R]C(=O)N1C=C(C)c2ccccc2C1</smiles>

389a: $R=$ OMe [66\%] 389b: $\mathrm{R}=\mathrm{NMe}_{2}[69 \%]$

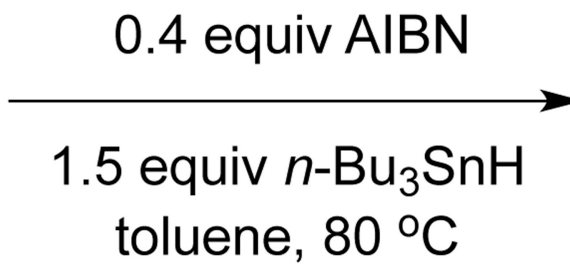<smiles>C=CCCC(=O)N1C=C(C)c2ccccc2C1</smiles>

389c: $55 \%$<smiles>[R]C(=O)N1C=C(C)c2ccccc2C1(C)C</smiles>

389<smiles>[R6]n1cc(C)c2ccccc21</smiles>
389d: $91 \%$

Scheme 103. 
<smiles>C=C=C(C)N1C(=O)OC[C@H]1Pc1ccccc1I</smiles>

390

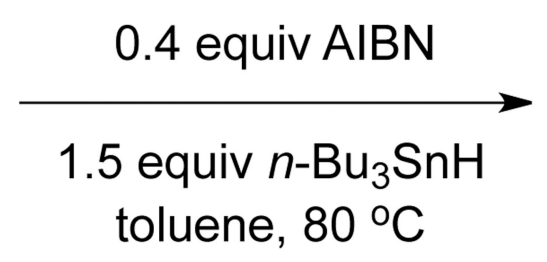
toluene, $80^{\circ} \mathrm{C}$

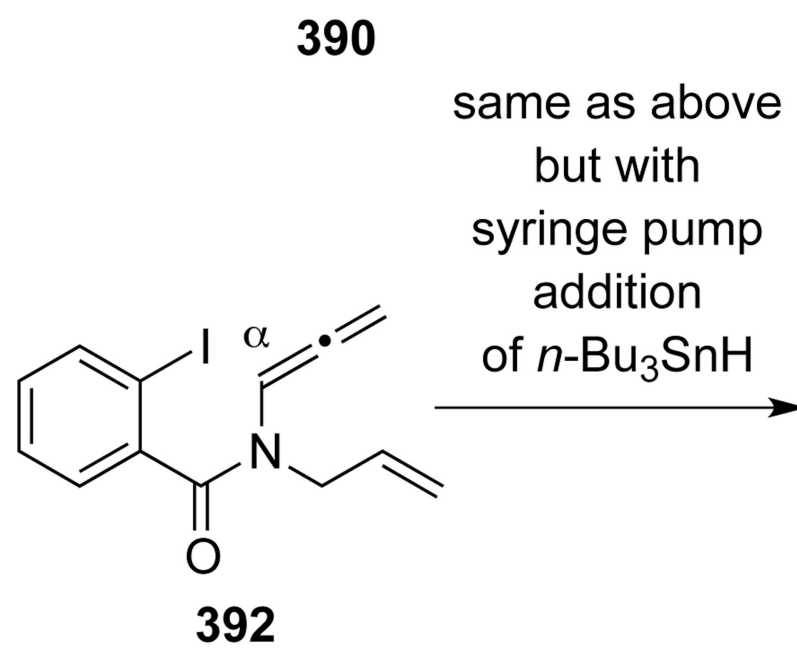

392

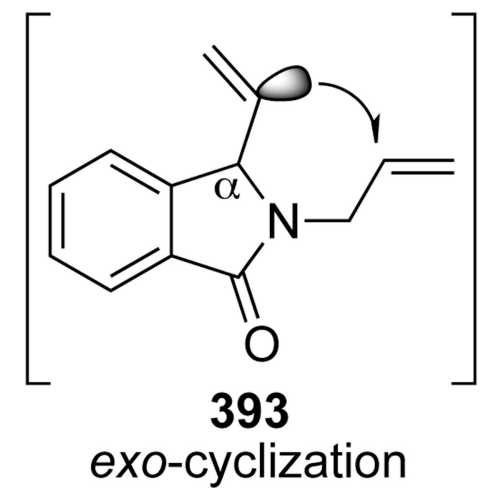

394: $34 \%$

Scheme 104. 

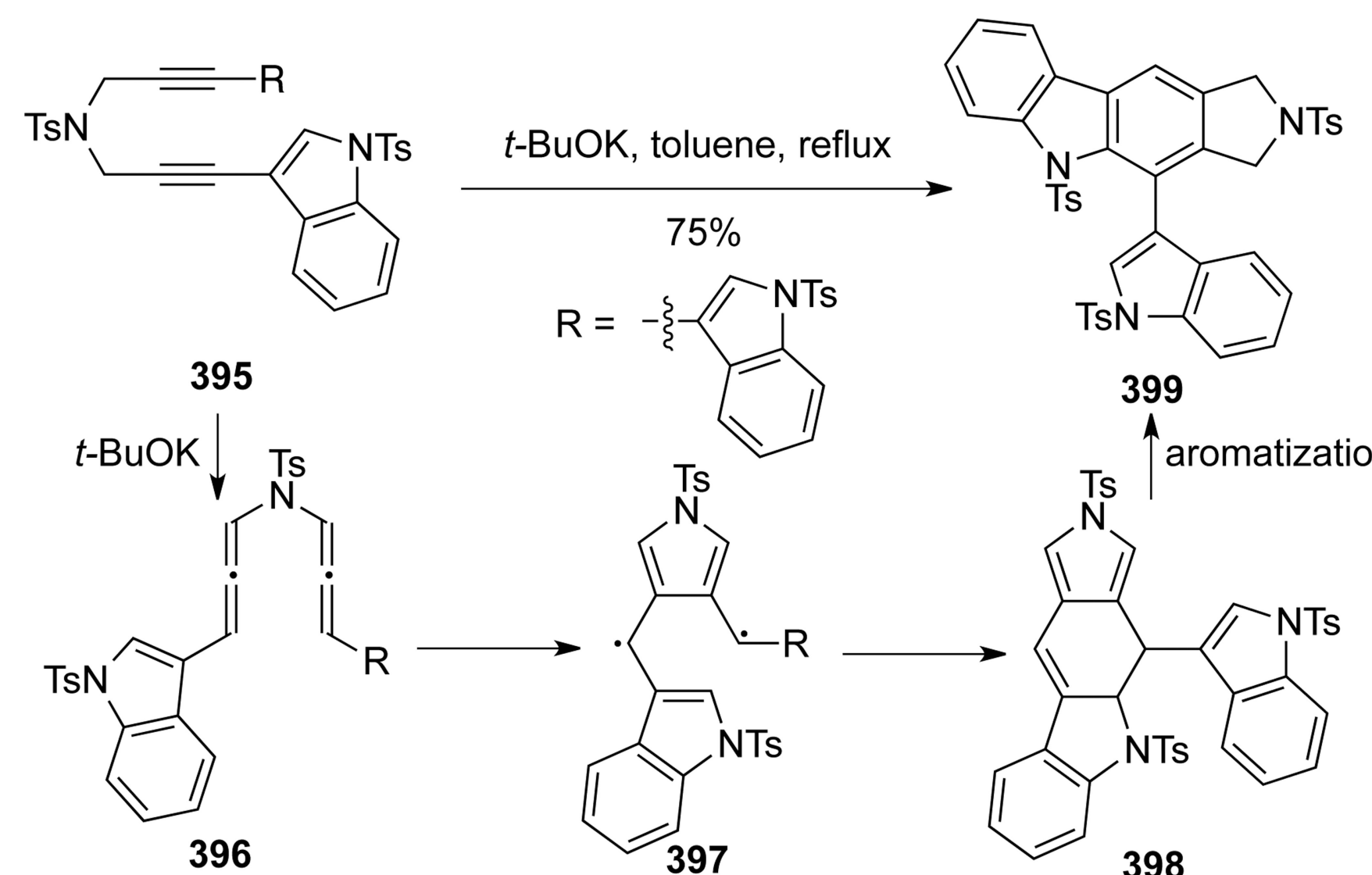

Scheme 105. 
<smiles>[R9]C=CC=C([R])C#CCN([Al])C([R7])=O</smiles><smiles>[R]C(=O)N([Ge])Cc1cc([R2])ccc1[R3]</smiles><smiles>[R]C(=O)N([Al])C=C1CC([R])=CC=C1[R9]</smiles>

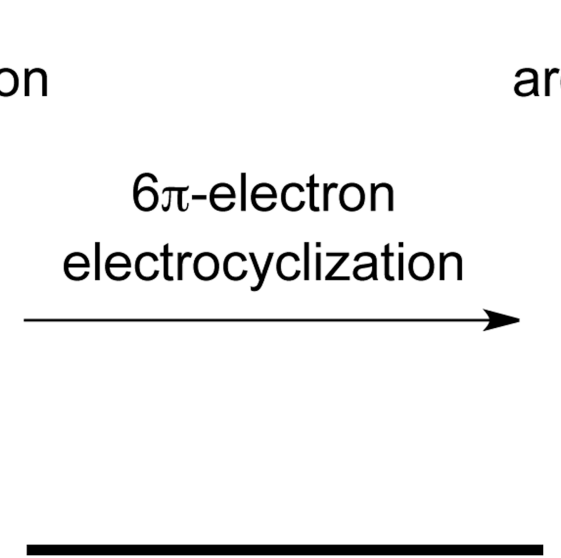

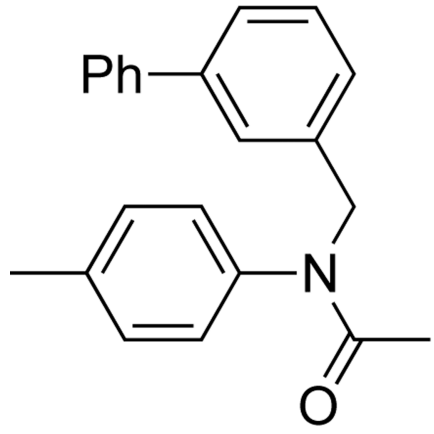

403a: 91\%

Scheme 106.

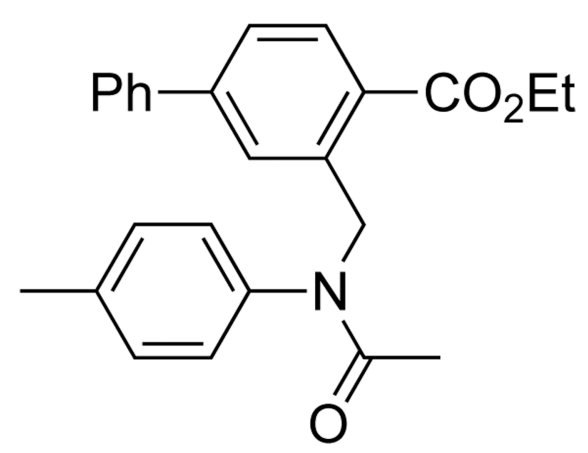

403b: $91 \%$ aromatization $\uparrow$
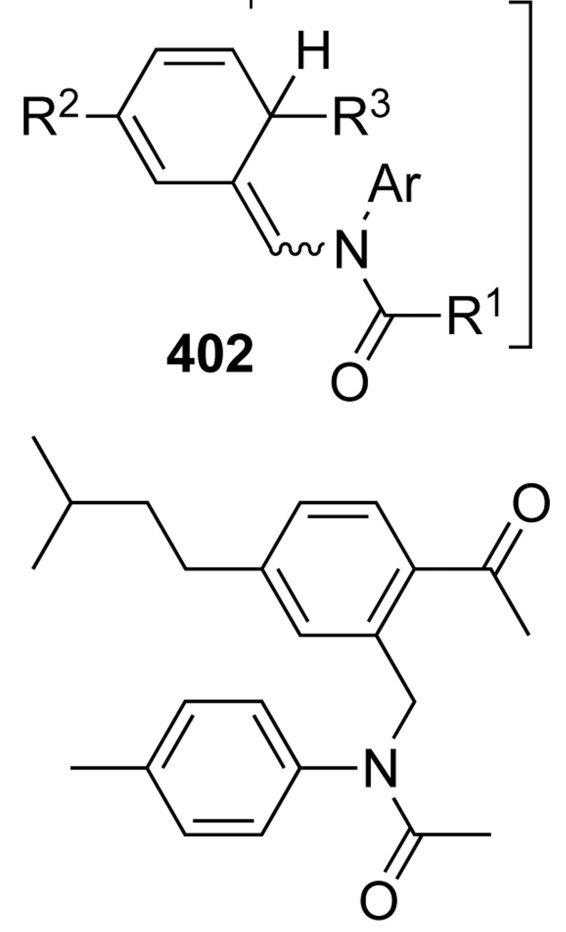

403c: $96 \%$ 
Lu et al.

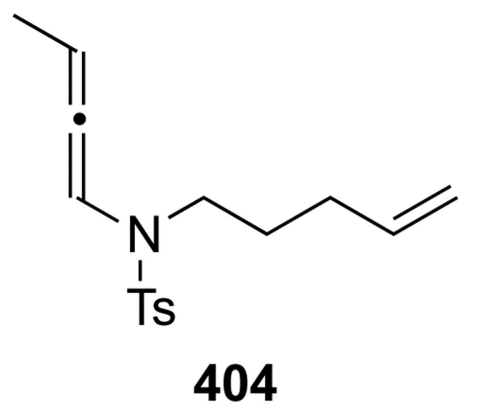

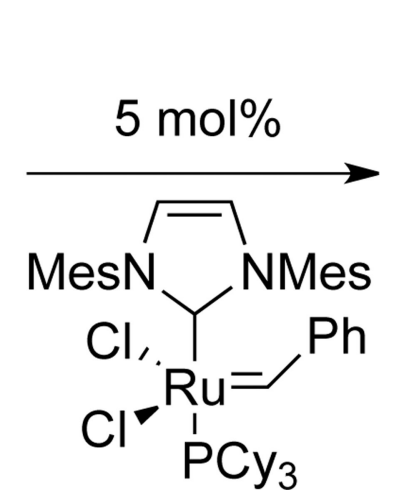

Page 143<smiles>C=CC=CN(C)[As]</smiles>
405 quant<smiles>[As]N1C=CCCC1</smiles>

406: not observed

Scheme 107. 
<smiles>C=C=C(CCCCO)N1C(=O)OC[C@H]1c1ccccc1</smiles>

407

408: epoxyallene

409

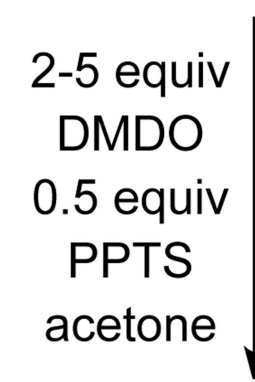<smiles>CCCCC</smiles><smiles>[R]CC(=O)[C@](CC)(OC)N1C(=O)OC[C@H]1P</smiles>
$\mathrm{R}$
2 equiv $m$-CPBA $\quad \mathrm{Ar}=m-\mathrm{Cl}-\mathrm{Bz}$

$\mathrm{NaHCO}_{3}, \mathrm{CH}_{2} \mathrm{Cl}_{2}$

$-78^{\circ} \mathrm{C}$ to rt<smiles>O=C1O[C@](CCCCO)(N2C(=O)OC[C@@H]2P)C(=O)[Al]1</smiles>

412: $58 \%$
$96 \%$ combined

$(411 a: 411 b=1: 3)$

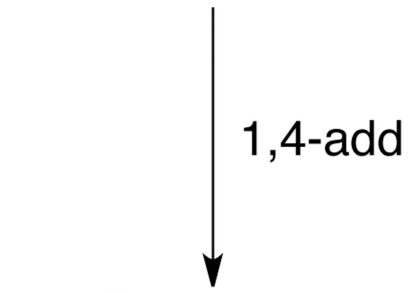

411b: $\mathrm{R}=\mathrm{OH}[d r 3.5: 1]$

Scheme 108. 
<smiles>[R]C(=C=C)N1C(=O)OC([R7])[C@H]1[R2]</smiles>

413
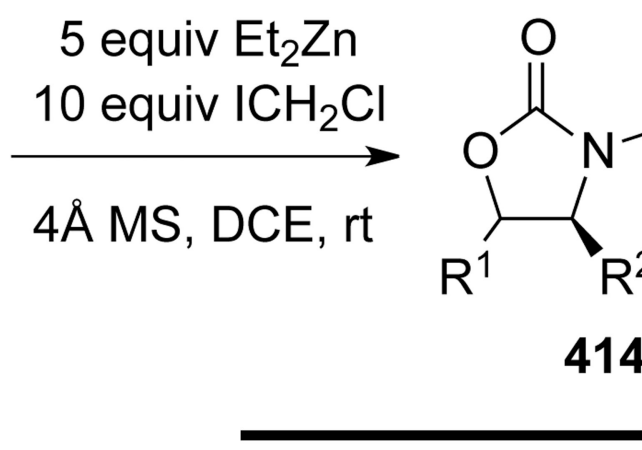

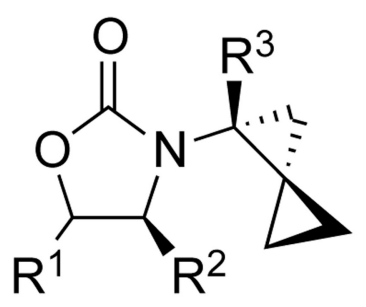

414<smiles>[R]C1OC(=O)N([C@]2([R3])C[C@H]2C)C1[R]</smiles>

415

$\mathrm{R}^{3}=\mathrm{H}$ : bis-cyclopropyl product 414 only<smiles>[R2]C1COC(=O)N1CC12CC1C2</smiles><smiles>[R]C1C(c2ccccc2)OC(=O)N1CC12CC1C2</smiles>

414a: $\mathrm{R}^{2}=\mathrm{Bn}[50 \% ; d r 3: 2]$ 414c: $\mathrm{R}^{2}=\mathrm{Me}[47 \% ; d r 1: 1]$ 414e: 30\%, $d r 2.1: 1$ 414b: $\mathrm{R}^{2}=\mathrm{Ph}[60 \% ; d r 3: 2]$ 414d: $\mathrm{R}^{2}=\mathrm{Ph}[54 \% ; d r 1: 1]$

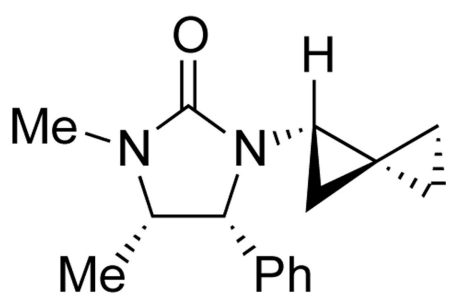

$\mathrm{R}^{3} \neq \mathrm{H}$ : a mixture of mono- and bis-cycloprop products<smiles>O=C1OCCN1C1(Br)CC12CC2</smiles>

414f: $29 \%$<smiles>C=C1CC1(Br)N1CCOC1=O</smiles>

415f: $42 \%$<smiles>CC(C)(C1C[C@H]1P)N1C(=O)OC[C@H]1P</smiles>

414g: 26\%, dr 3.5:1

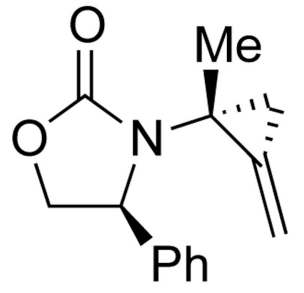

415g: 38\%, dr 3.5:1

Scheme 109. 


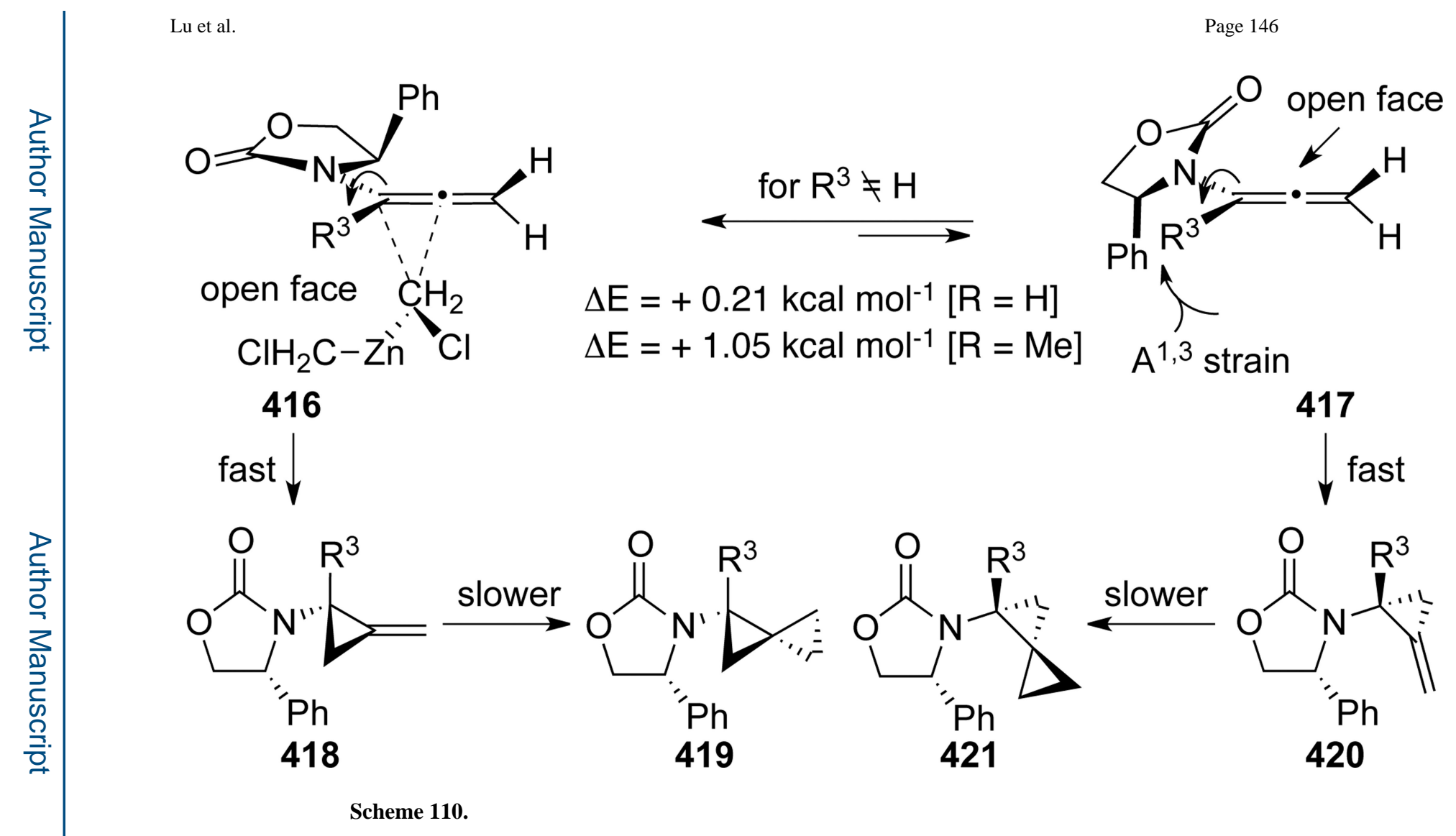


<smiles>[R7]N1C(=O)OCC1=C=C</smiles>

422<smiles>O=C1OCC(=C2CC(c3ccccc3)C2)N1[AsH-]</smiles>

423a: $73 \%$<smiles>[R7]C(=O)N1C(=O)OCC1=C1CC(c2ccccc2)C1</smiles>

423e: $70 \%$<smiles>[R]C#CCC(=O)O[Na]</smiles><smiles>[R]N1C(=O)OCC1=C1CC([R2])(C)C1</smiles>

423

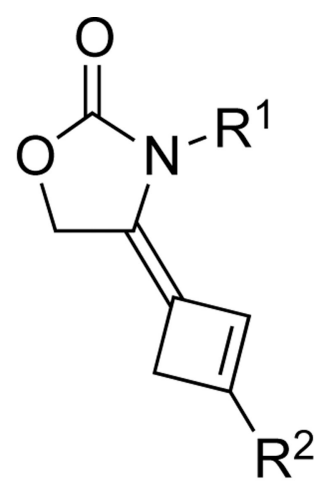

424
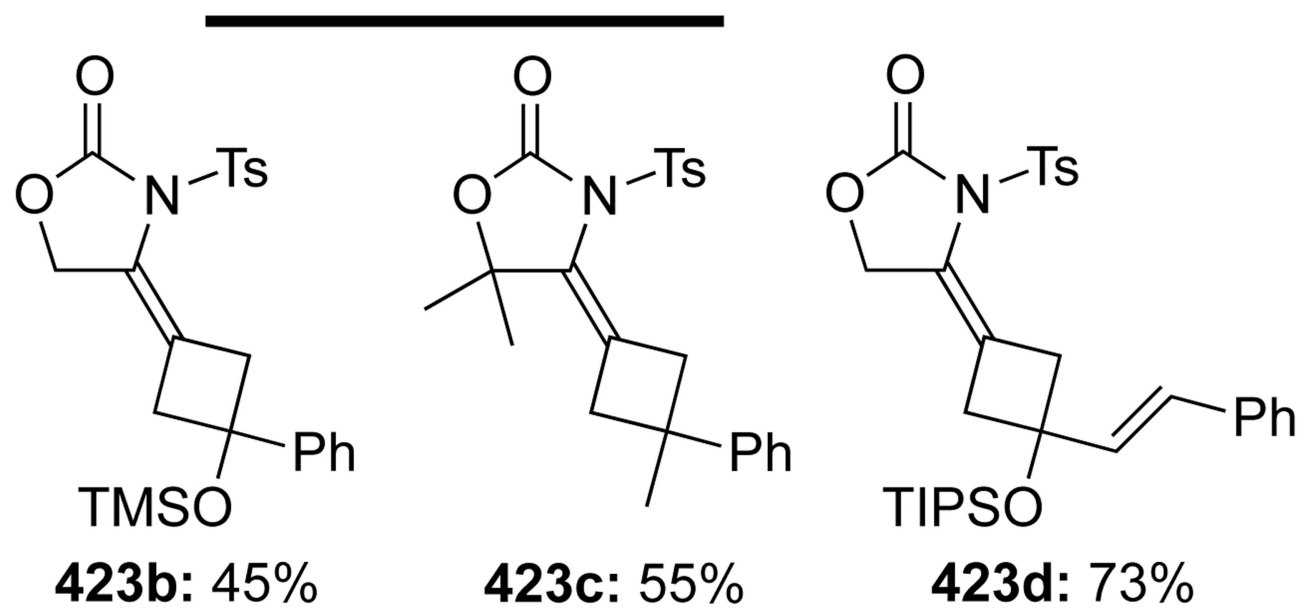

423c: $55 \%$

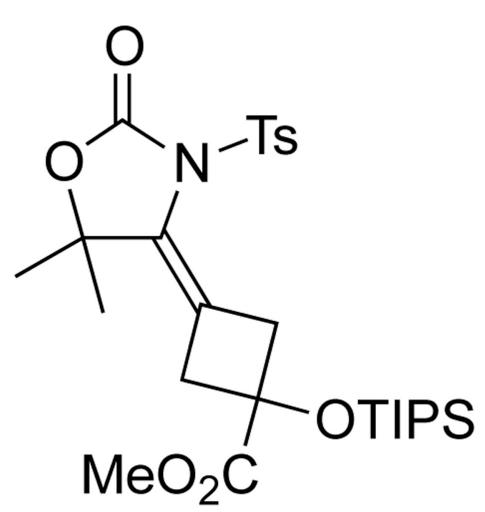

423f: $98 \%$

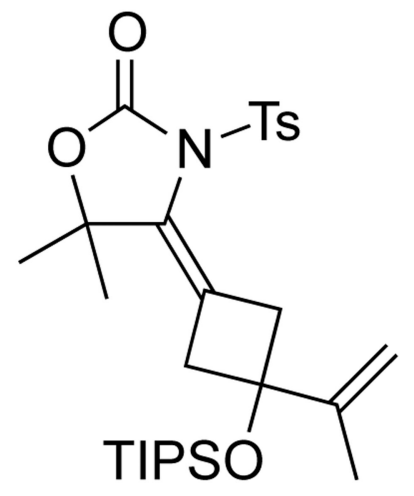

423g: $80 \%$ 423d: $73 \%$

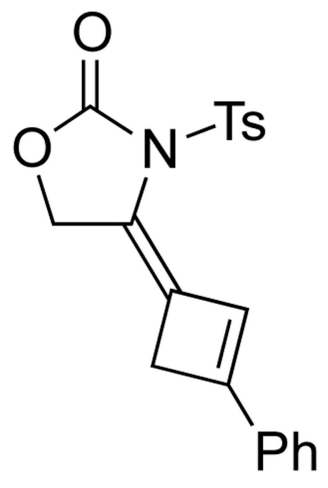

424a: $60 \%$

Scheme 111. 
<smiles>C=C=C1N([As])C(=O)OC1(C)C</smiles>

426: $70 \%$

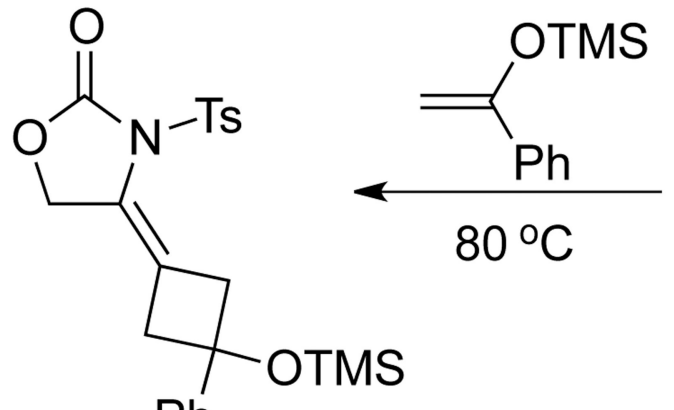

429: $55 \%$
425<smiles>C=C=C1COC(=O)N1[AsH-]</smiles>

428

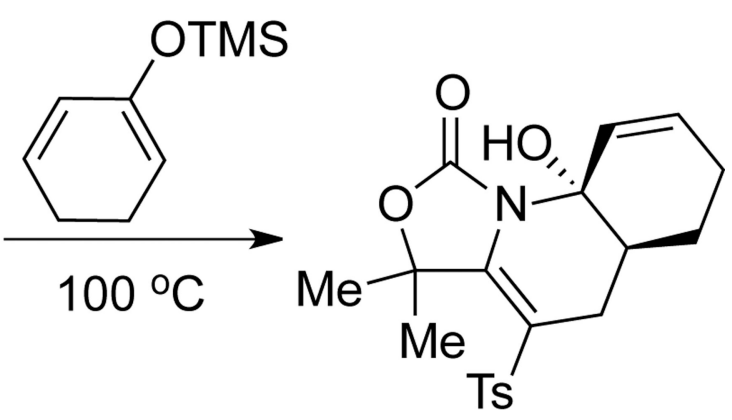

427: $65 \%$

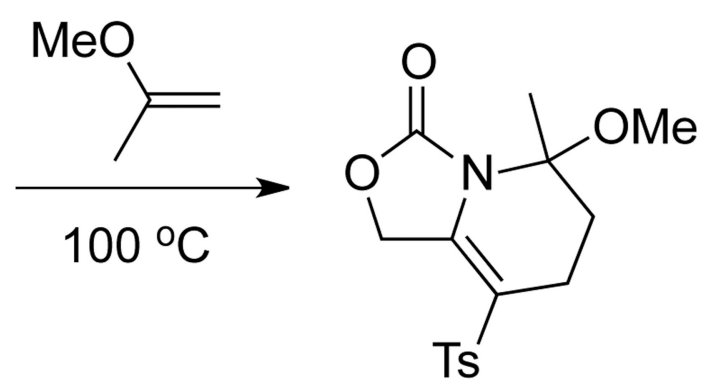

430: $86 \%$

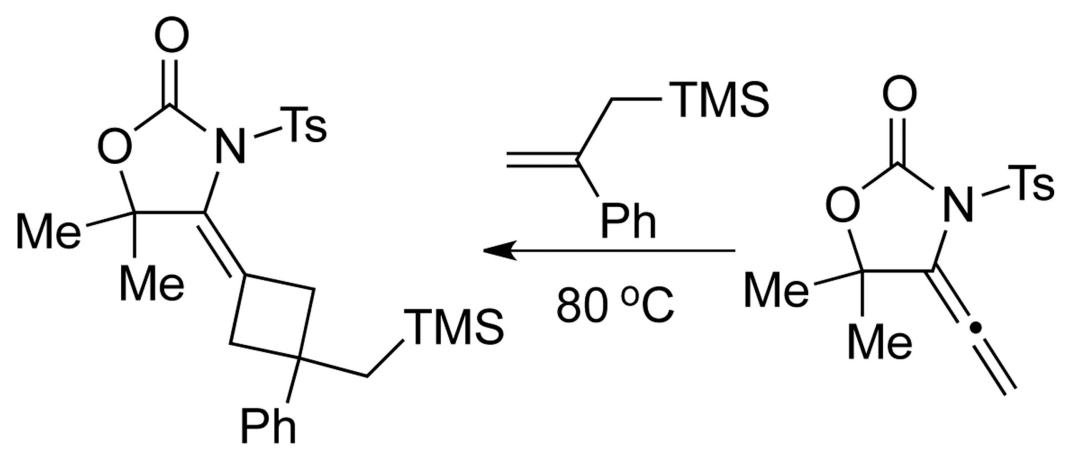

432: $85 \%$

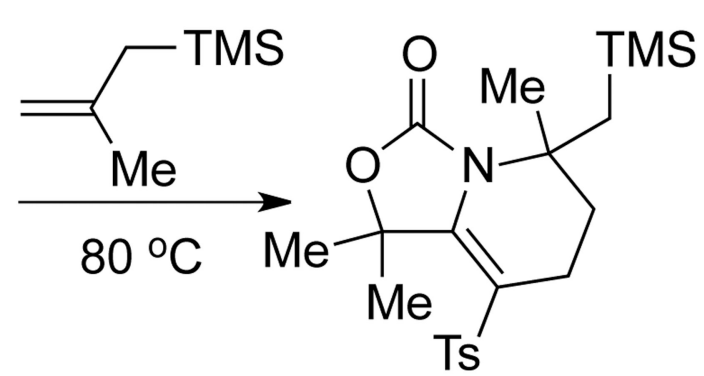

433: $57 \%$

Scheme 112. 


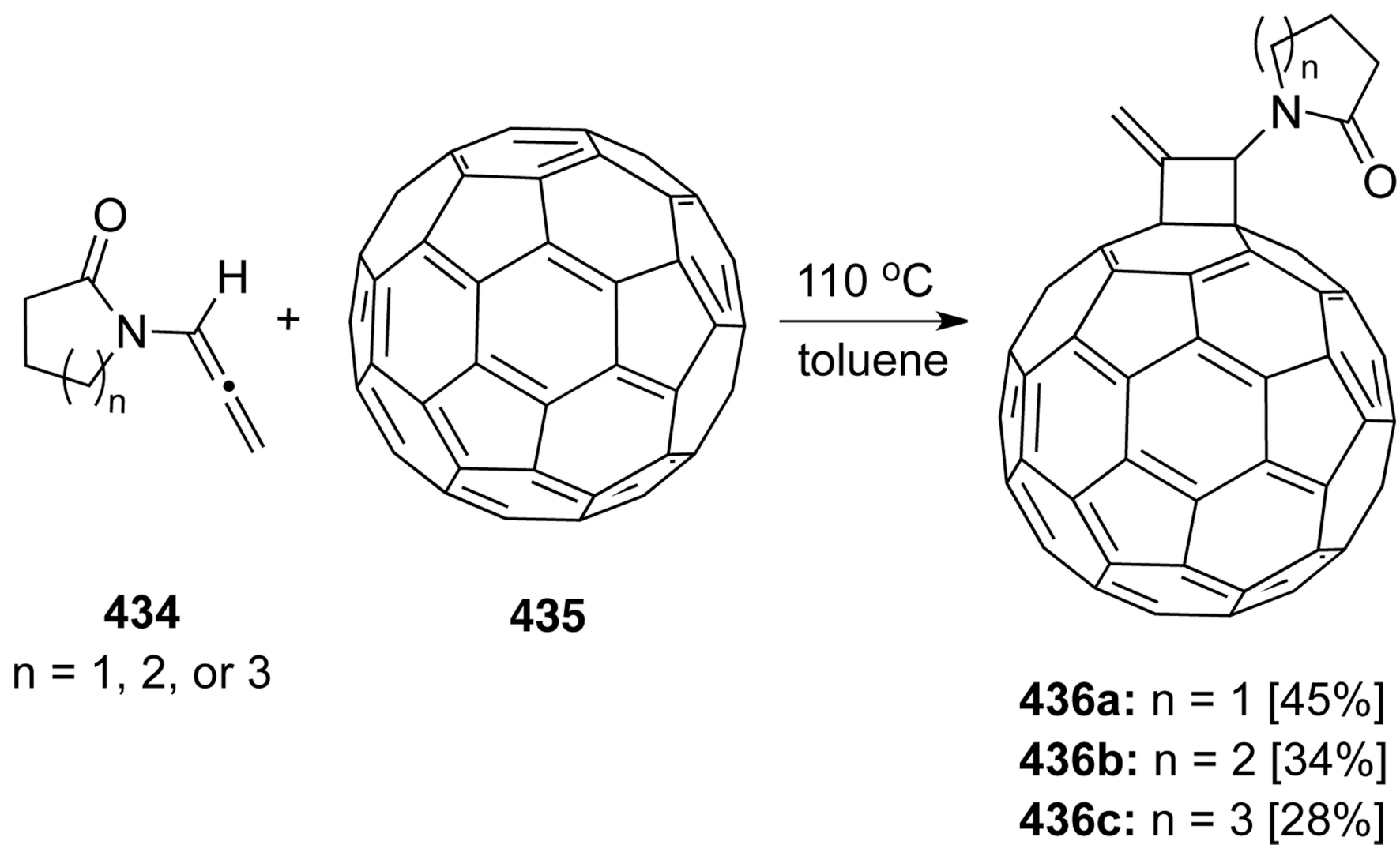

Scheme 113.

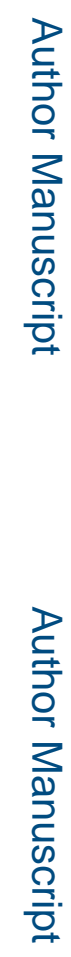


<smiles>[R9]C=C/C=C\[R4]([R5])=S</smiles>
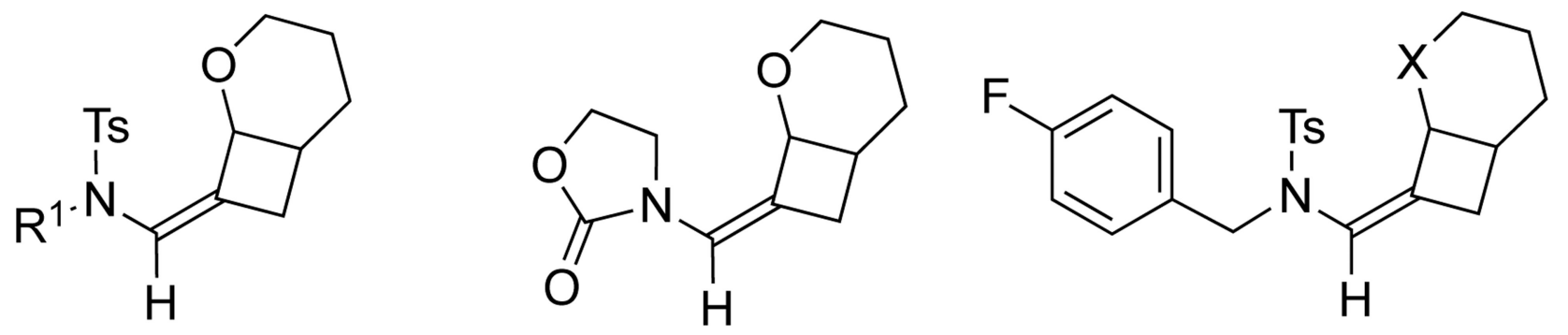

439a: $\mathrm{R}^{1}=n-\mathrm{Bu}[61 \%]$

439c: $82 \%$

439d: $X=O[87 \%]$

439b: $\mathrm{R}^{1}=1,3,5-\mathrm{Me}_{3} \mathrm{C}_{6} \mathrm{H}_{2}[85 \%]$

439e: $X=$ NBoc $[78 \%]$

(1)

$\mathrm{R}$<smiles>CC(C)=C1CCC1c1ccc(C)cc1</smiles>

$\mathrm{H}$

439f: $R=$ OEt [83\%]

439g: $\mathrm{R}=t-\mathrm{Bu}[68 \%]$
$\mathrm{MeO}$<smiles>COC1(C)CCC1=C(C)N([As])Cc1ccc(F)cc1</smiles>

439h: $69 \%$ is

439i: $85 \%$

Scheme 114. 


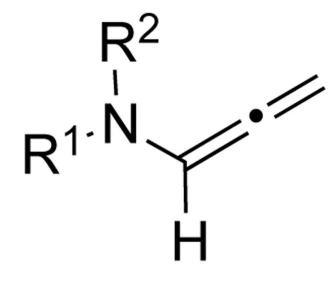

437<smiles></smiles>

440a: $\mathrm{R}=n-\mathrm{Bu}[76 \%]$ 440b: $\mathrm{R}=\mathrm{Ph}[38 \%]$

Scheme 115.
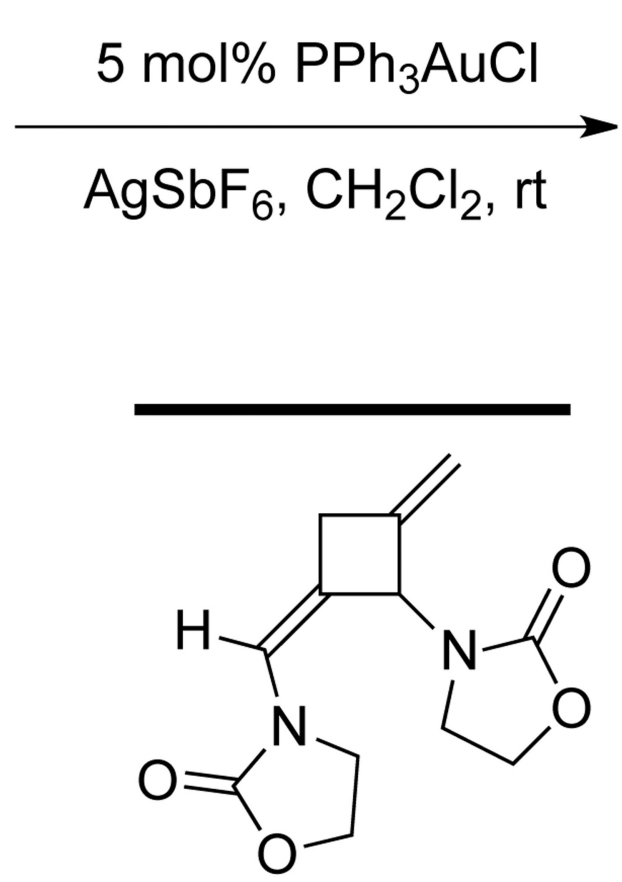

440c: $56 \%$
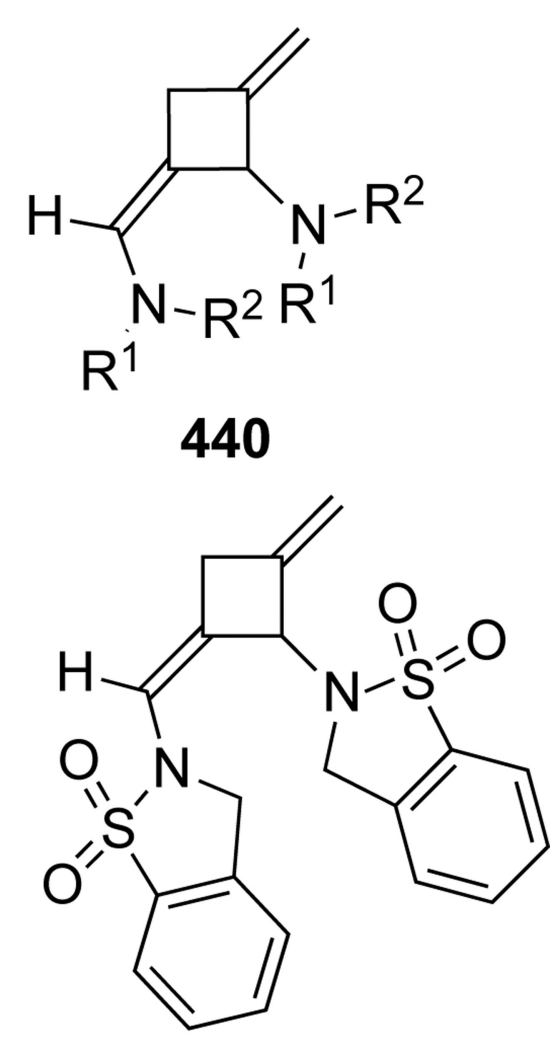

440d: 56\% 


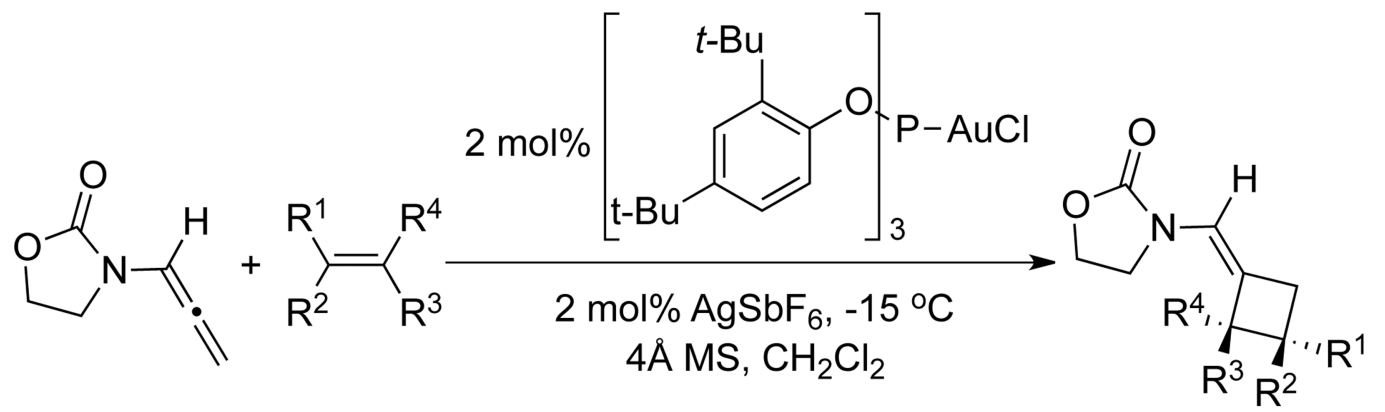

441

442

443<smiles></smiles>

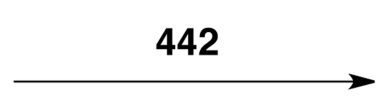<smiles>[R]C1CCC1=CN1CCOC1=O</smiles>

443a: $\mathrm{R}=\mathrm{Ph}[81 \%]$

443b: $\mathrm{R}=\mathrm{o}-\mathrm{MeC}_{6} \mathrm{H}_{4}[96 \%]$<smiles>CC1C/C(=C/N2CCOC2=O)[C@H]1c1ccccc1</smiles>

443c: $79 \%$<smiles>O=C1OCCN1/C=C1/C[C@H]2CCCC[C@]12c1ccccc1</smiles>

443g: $74 \%$

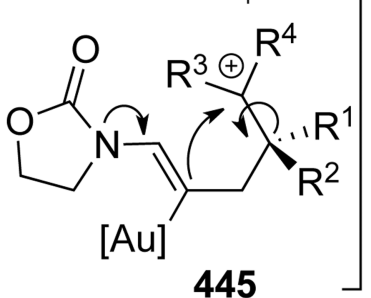<smiles>C[C@]1(c2ccccc2)CCC1=CN1CCOC1=O</smiles>

443d: $77 \%$<smiles>CC1CC(=CN2CCOC2=O)C1</smiles>

443e: $X=O[76 \%]$

443f: $\mathrm{X}=\mathrm{CH}_{2}[71 \%]$

Scheme 116.<smiles>O=C1OCCN1/C=C1/C[C@@H]2CCCN(C(=O)O)[C@H]12</smiles>

443h: $94 \%$ 
<smiles>[R]C=C=C=C([Y7])N([R7])[I-]</smiles><smiles></smiles>

Scheme 117.

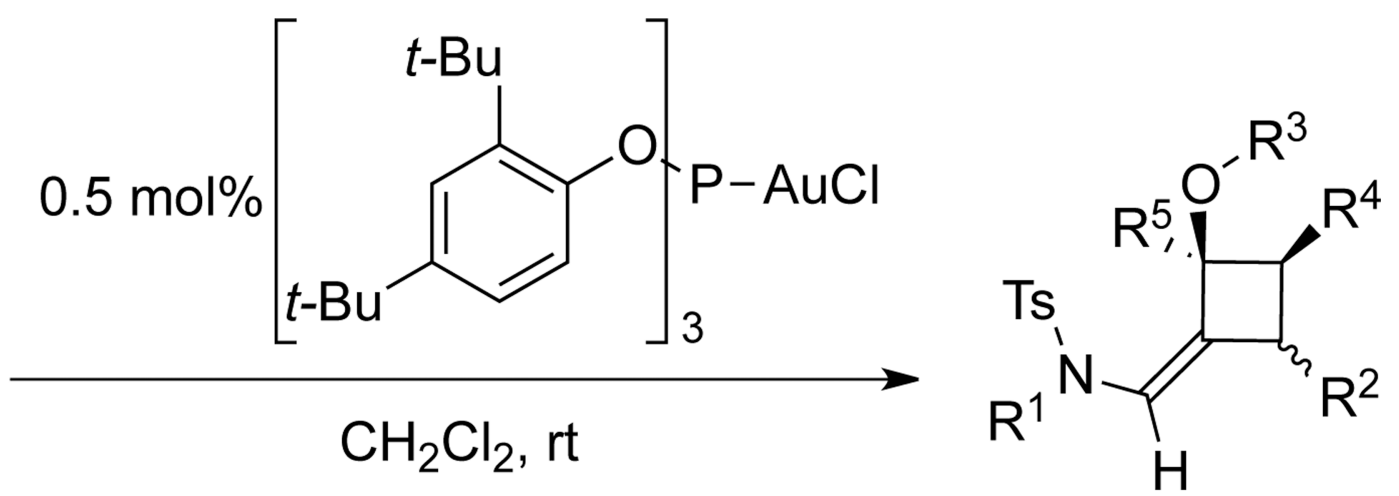

448
447

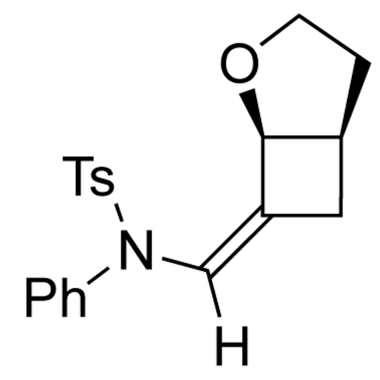

448a: $86 \%$

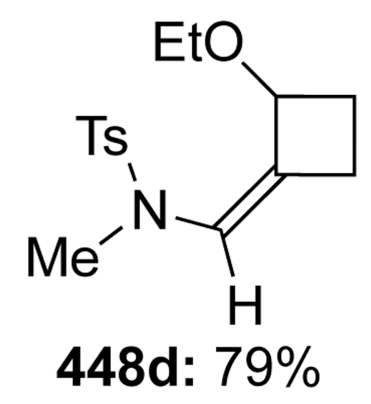

448e: $72 \%, d r 3: 1$
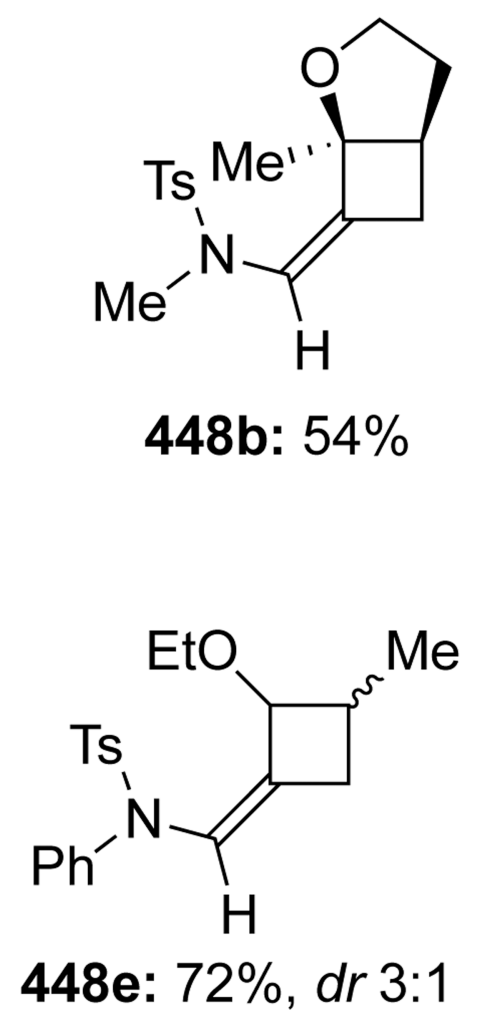

448b: $54 \%$

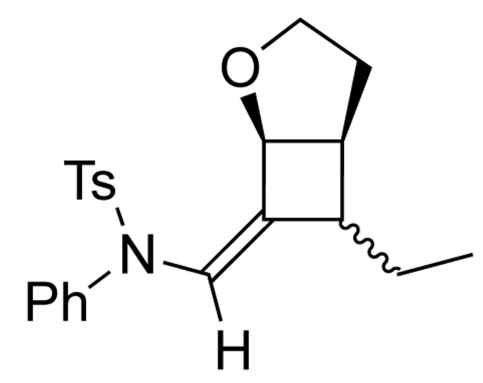

448c: $85 \%, d r 1: 1$

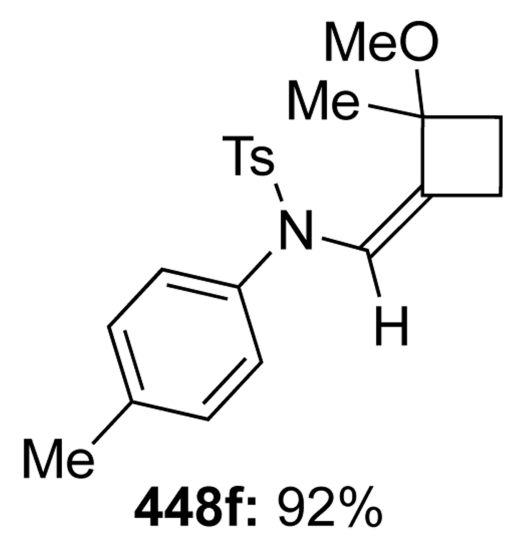




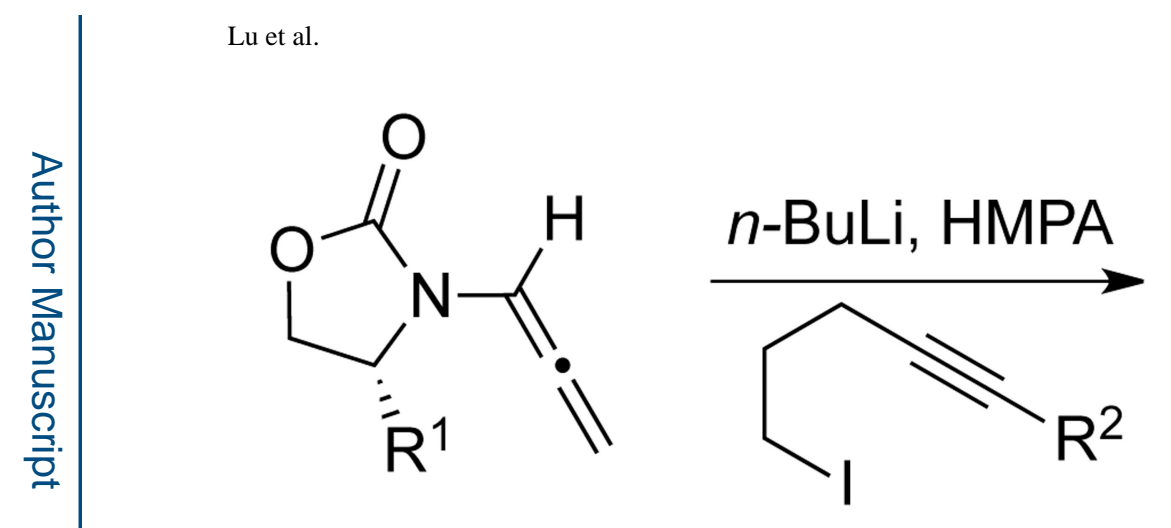

449

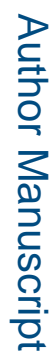

롤

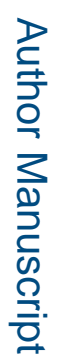

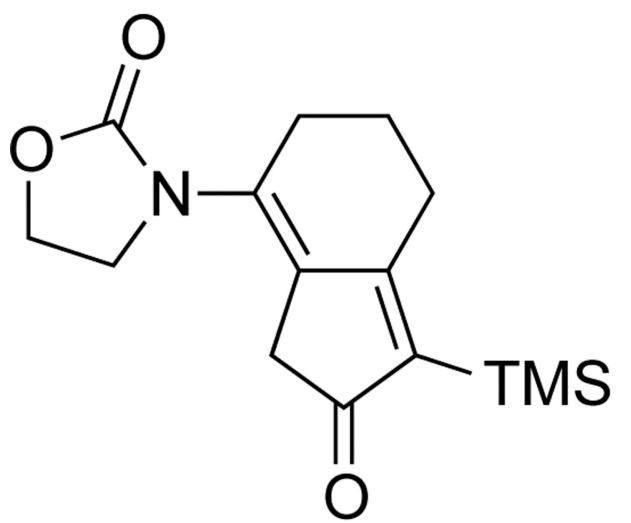

451a: 59\%

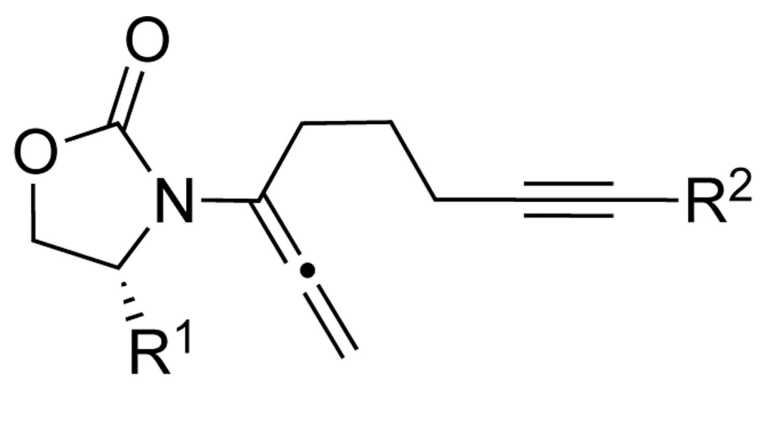

450

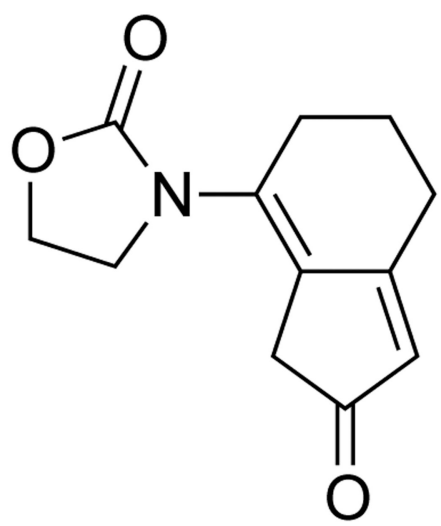

451b: 50\%

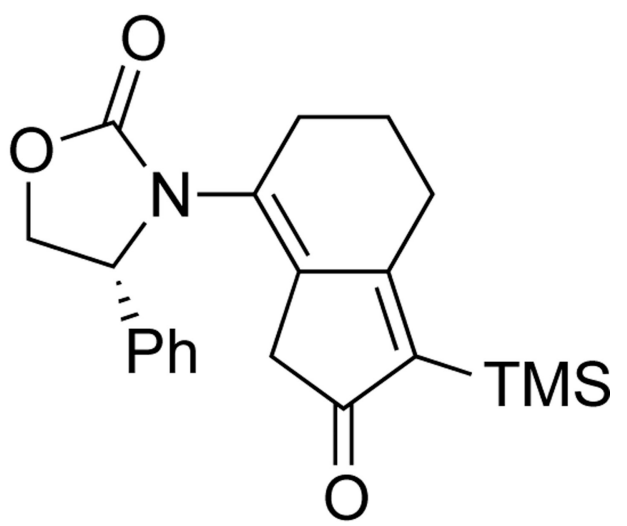

451c: $55 \%$ 
<smiles>[R]c1ccc(N(C)C=C=C)c([R])c1</smiles>

452 Z

1.5 equiv $\mathrm{Co}(\mathrm{CO})_{8}$

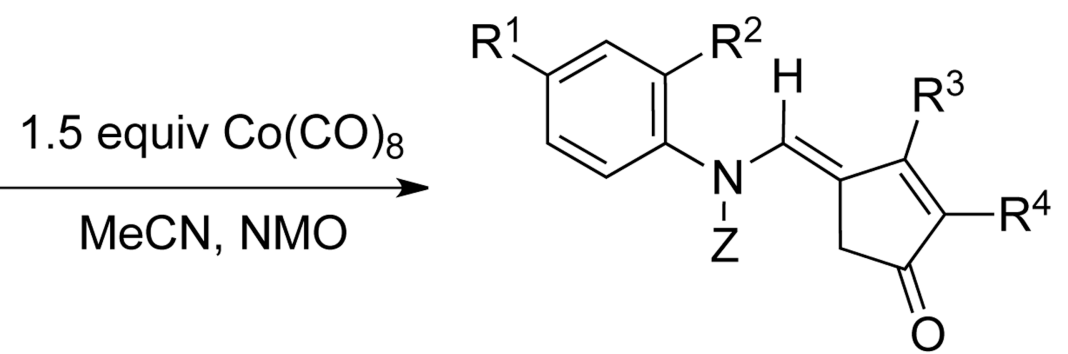<smiles>[R][Z]#C[R]</smiles>
MeCN, NMO

454

MeO

453<smiles>[R3]C1=CC(=O)C/C1=C\N([14CH3])c1ccc(C)cc1</smiles>

454a: $\mathrm{R}^{3}=p$-Tolyl [45\%]<smiles>[Y]c1ccc(N([AlH2])/C=C2\CC(=O)C(CC)=C2CC)cc1</smiles>

454b: $\mathrm{R}^{3}=\mathrm{Bu}[50 \%]$

454c: $X=$ OMe [65\%]

454d: $X=F[61 \%]$

Scheme 119. 
Lu et al.

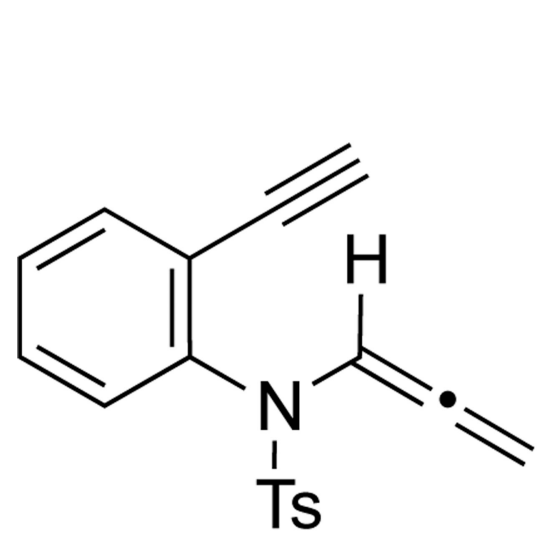

455
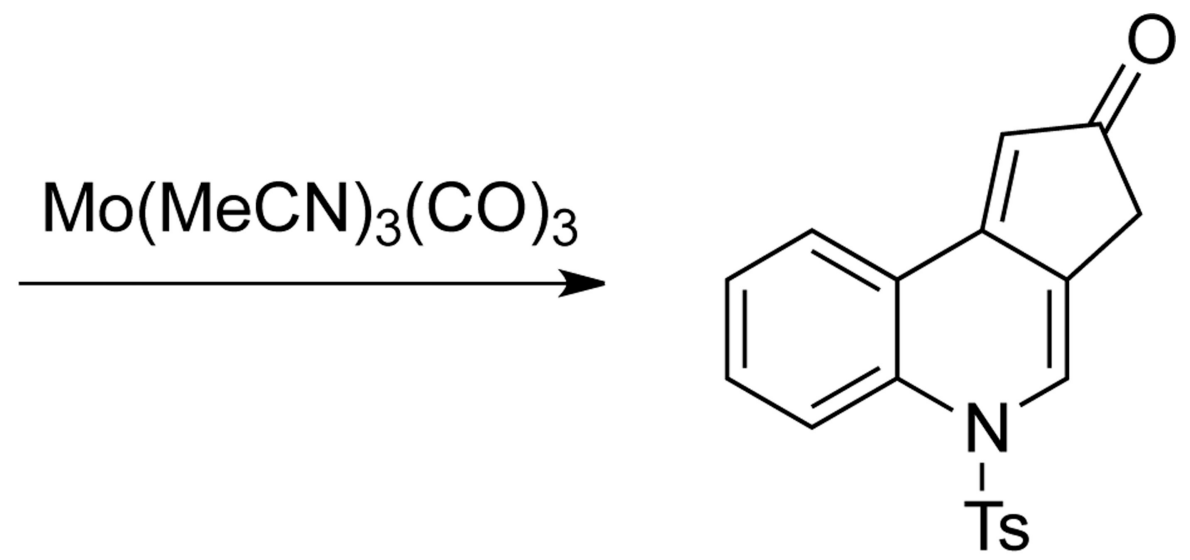

456: $43 \%$

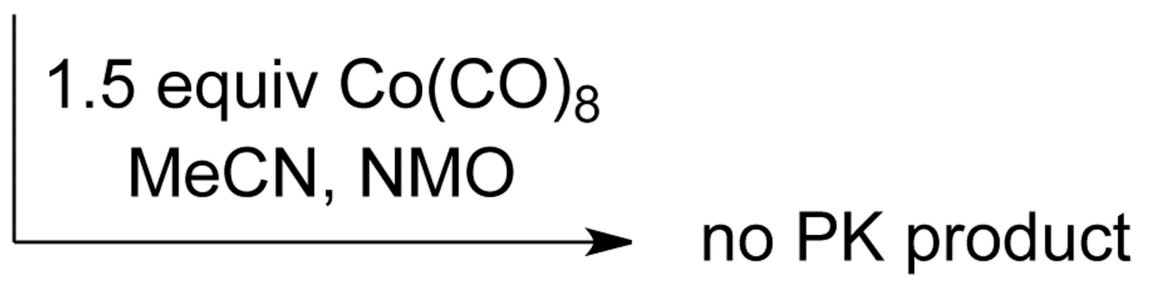

Scheme 120. 


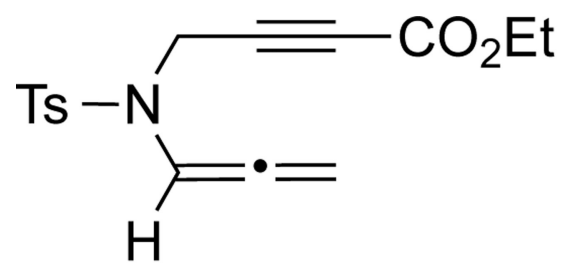

457

Scheme 121.

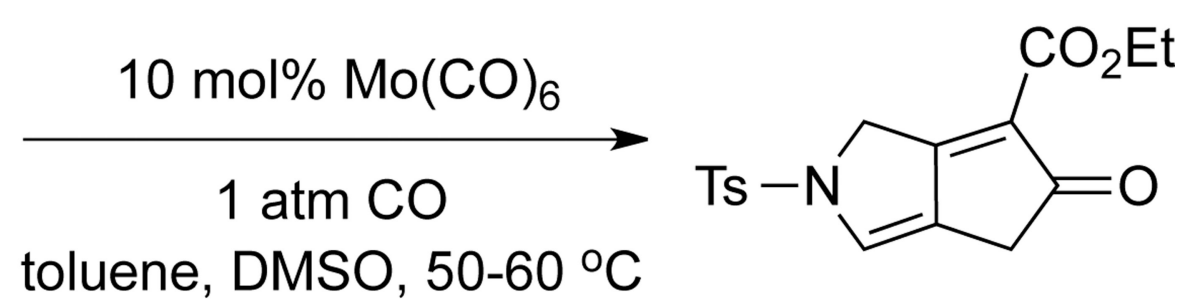

458: $63 \%$ 


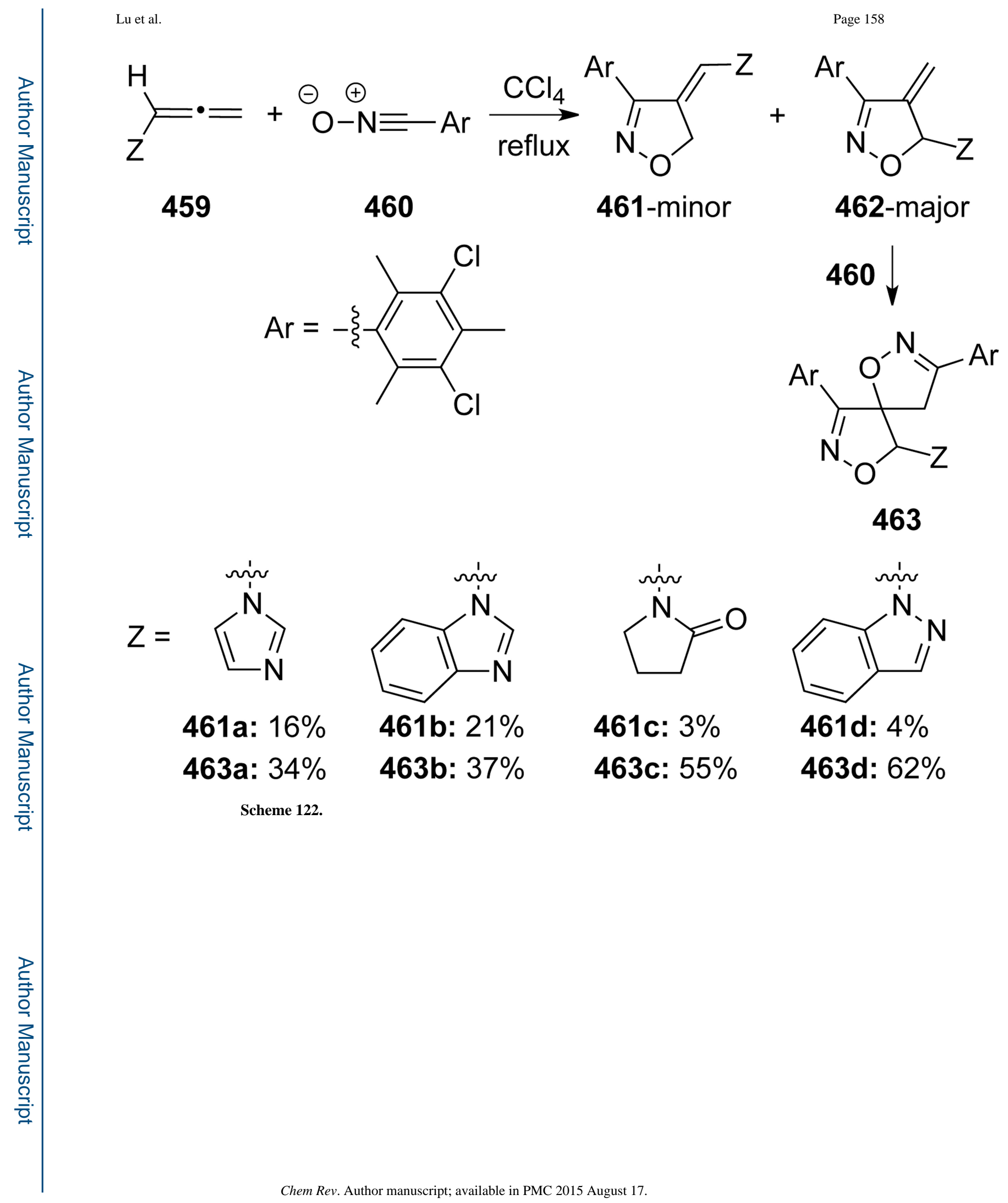


<smiles>[R]C1([R])OC(=O)N([AsH2-])C1=C=C</smiles>

464

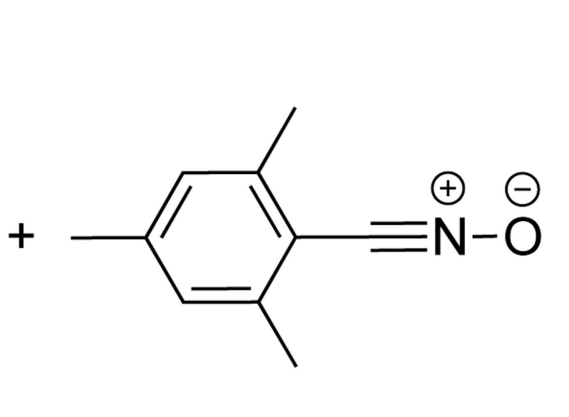

465

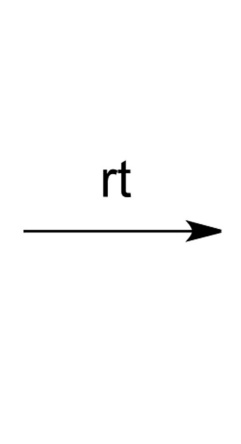

466a: $\mathrm{R}=\mathrm{H}[50 \%]$ 466b: $R=\operatorname{Me~[60\% ]~}$ 466c: $\mathrm{R}=-\left(\mathrm{CH}_{2}\right)_{4}-[66 \%]$

Scheme 123. 


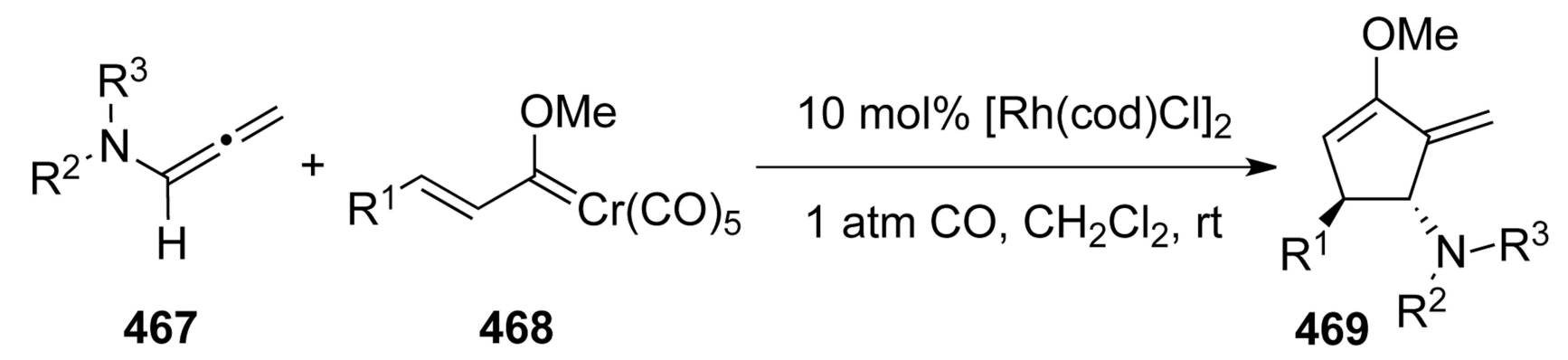<smiles>[R7]C1C=C(OC)C(=C)[C@@H]1N1CCCC1=O</smiles>

469a: $\mathrm{R}^{1}=\mathrm{C}_{6} \mathrm{H}_{5}[78 \%]$ 469b: $R^{1}=2$-furyl [80\%]

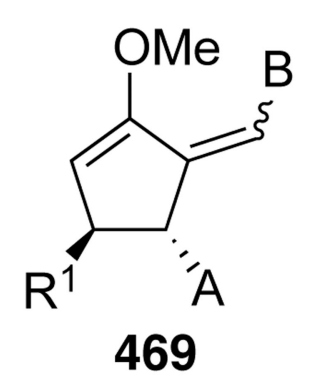<smiles>[B]C=C=CC</smiles>

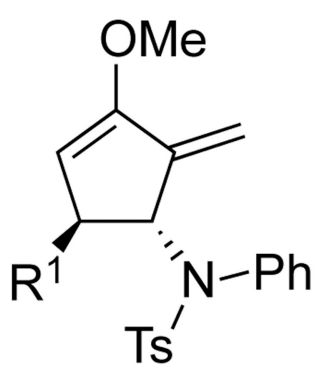

469c: $\mathrm{R}^{1}=\mathrm{C}_{6} \mathrm{H}_{5}[88 \%]$ 469d: $R^{1}=2$-furyl [88\%]

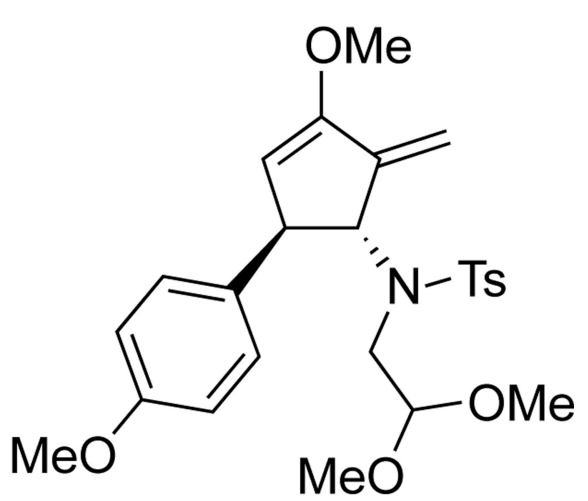

469e: $98 \%$

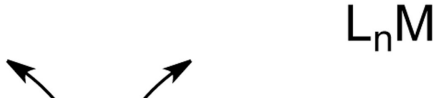

Scheme 124. 


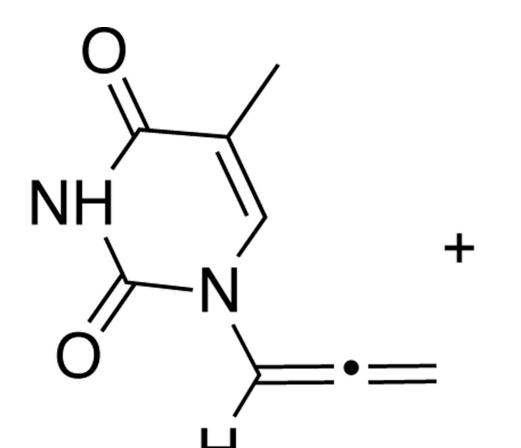

$\mathrm{H}$

471

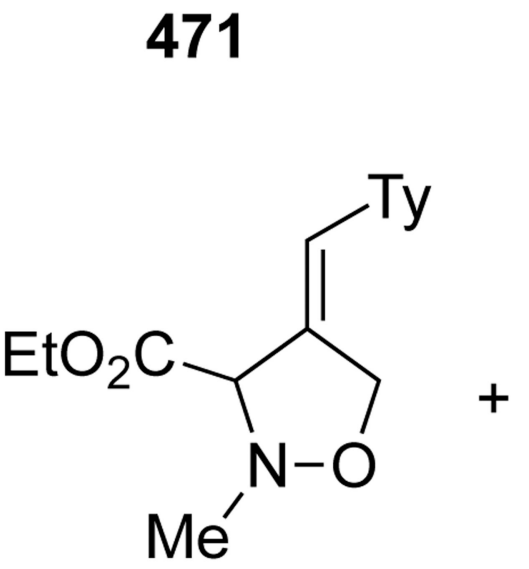

473

472
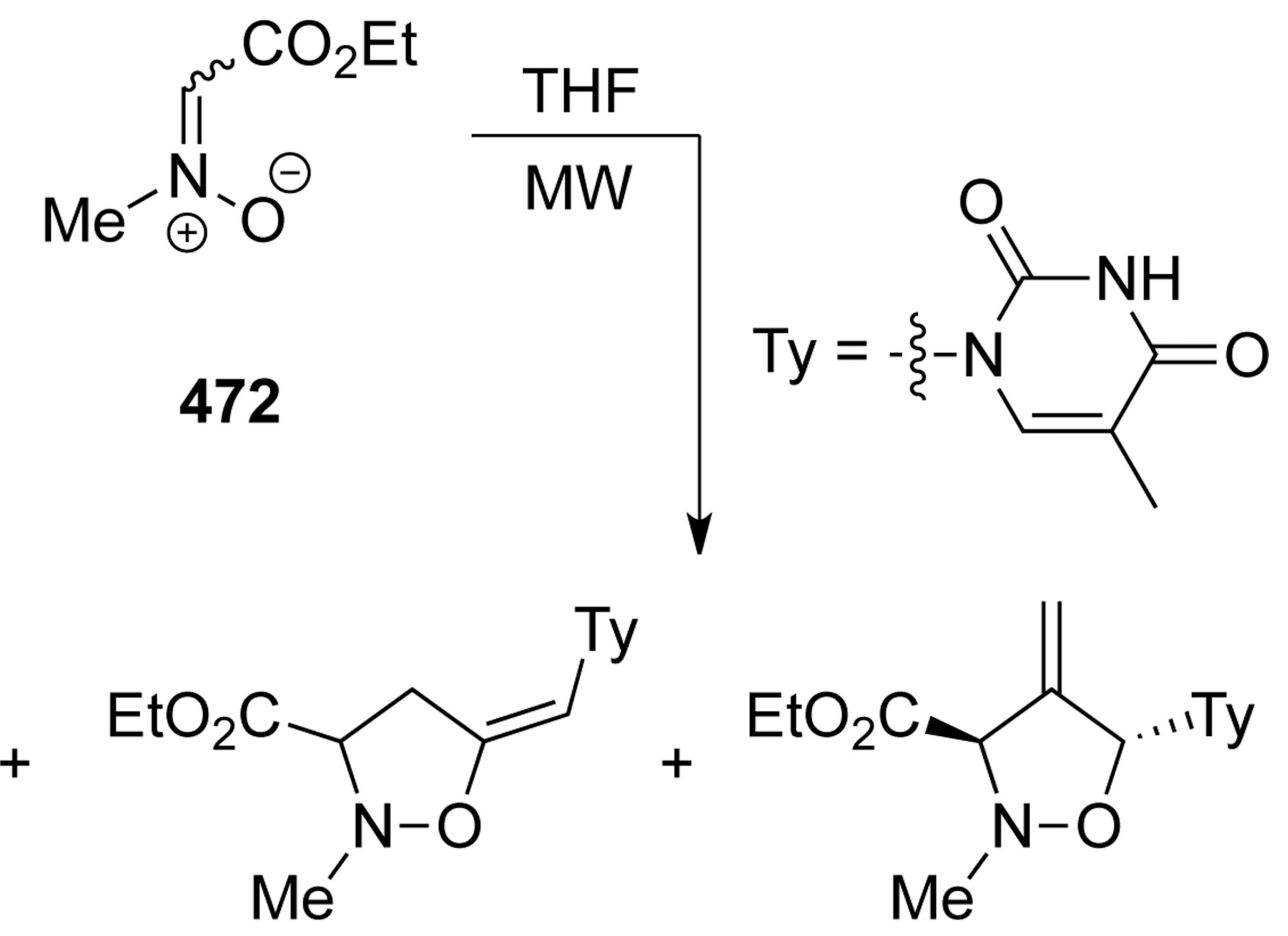

474

475

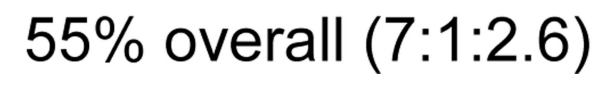

Scheme 125. 
<smiles>BC=C=C(C)CO</smiles>

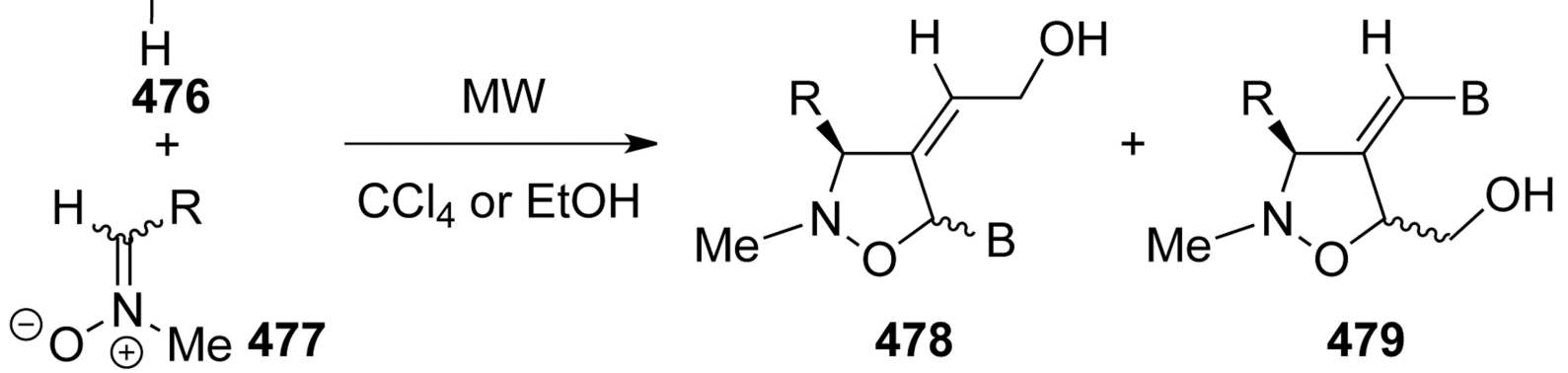

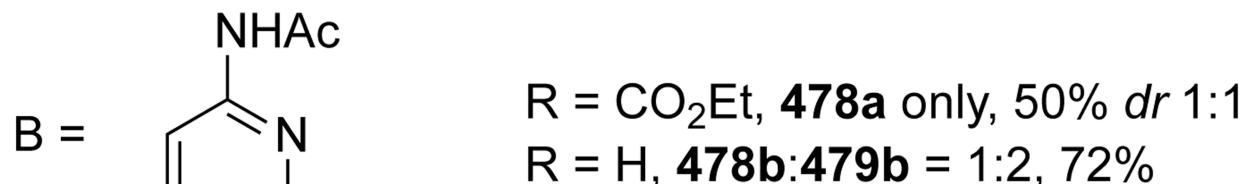

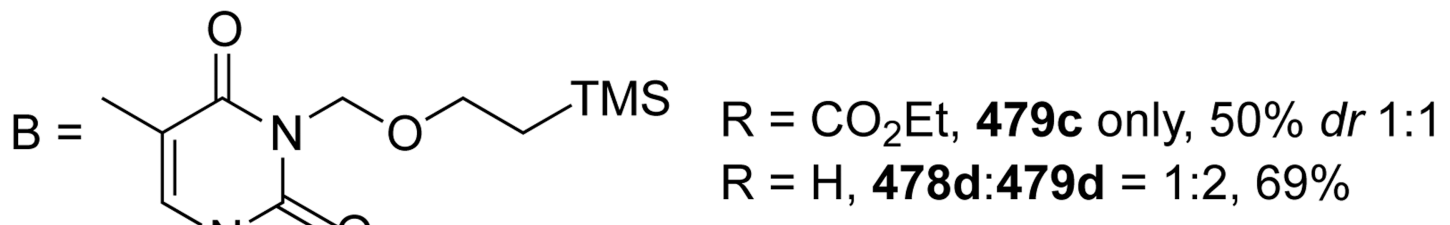

Scheme 126. 
<smiles>[R]C#[R7]C([R])(O)C#C[R]</smiles>

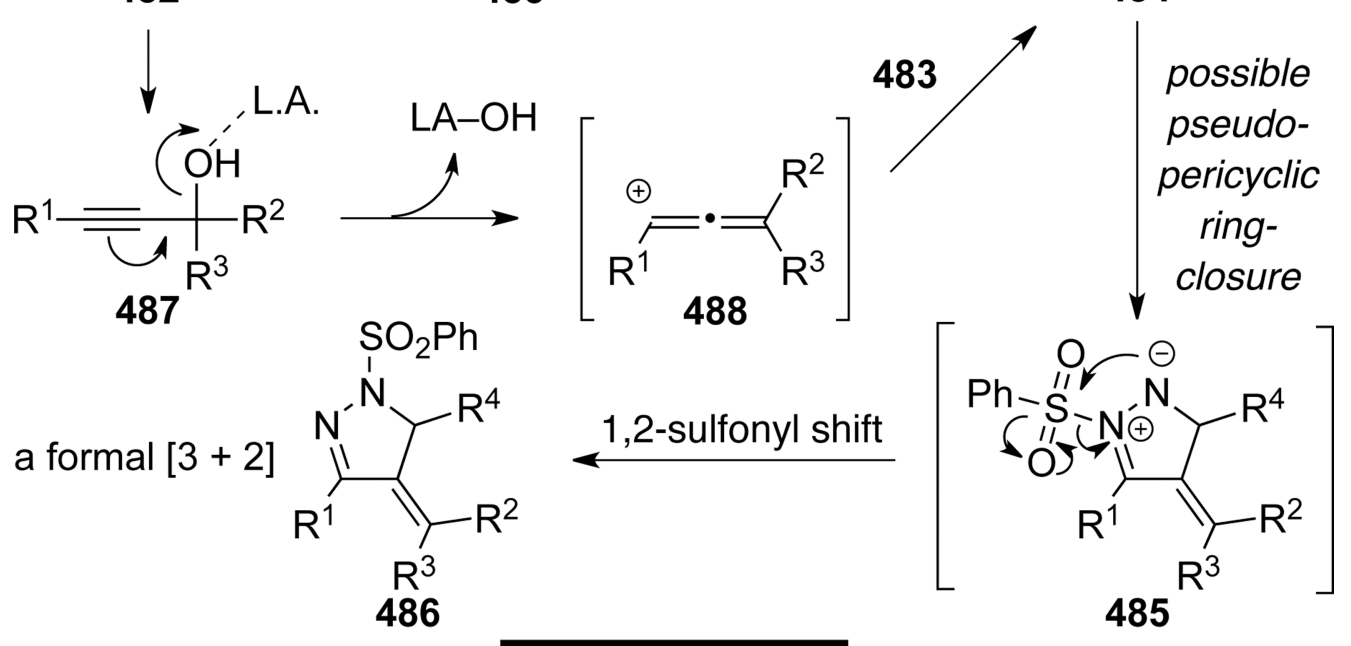<smiles>O=S(=O)(c1ccccc1)N1N=CC(=C(c2ccccc2)c2ccccc2)C1c1ccc(Br)cc1</smiles>

486a: $63 \%$

$\mathrm{PhO}_{2} \mathrm{~S}$<smiles>Cc1ccc(C(=C2C=NNC2c2ccccc2)c2ccc(Cl)cc2)cc1</smiles>

Cl 486d: $72 \%$<smiles>C=C(C(=NP(=O)(O)c1ccccc1)C(=C(c1ccccc1)c1ccccc1)c1ccccc1)c1ccccc1</smiles>

486e: $37 \%$<smiles>C/C(=C1\C=NN(S(=O)(=O)c2ccccc2)C1c1ccc(C)cc1)c1ccccc1</smiles>

486c: $78 \%$

Scheme 127. 
Lu et al.
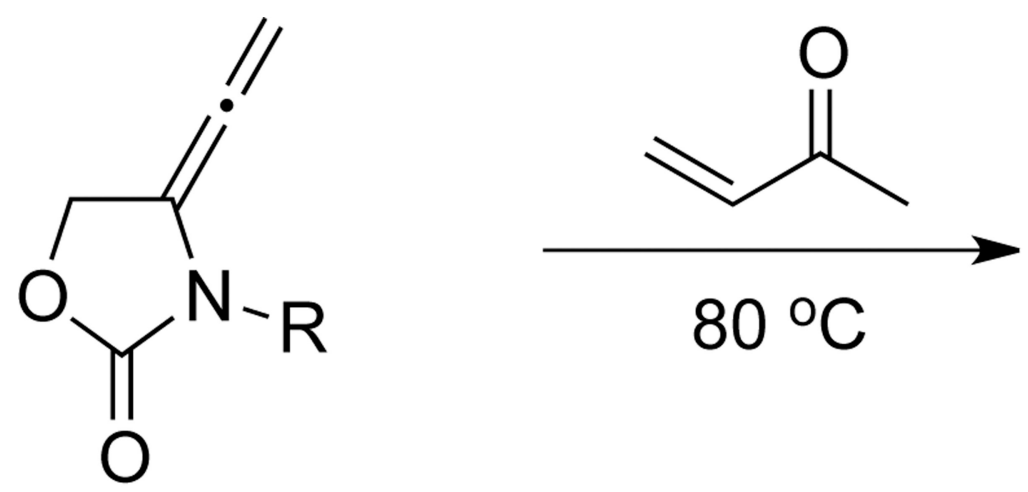

489

Scheme 128.
Page 164

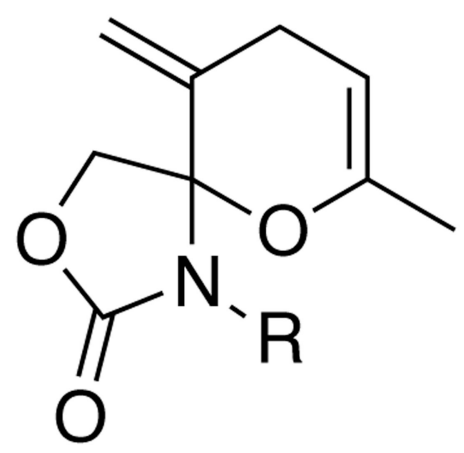

490a: $R=T s$ [86\%] 490b: $R=B z$ [81\%] 
<smiles>[3H]N1C(=O)OC2(CCCC2)C1=C=C</smiles>

491<smiles>[R]C(=O)C(=C)C</smiles>

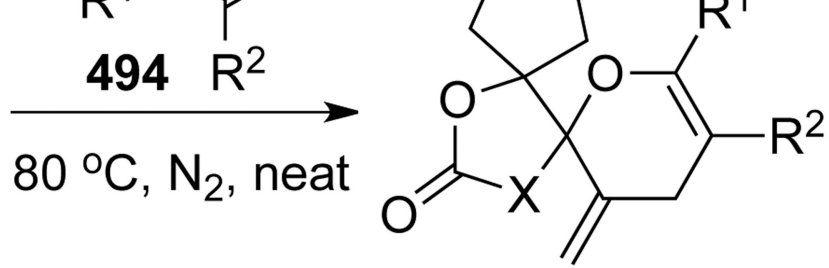

492: $X=N T s$<smiles>[R]C(=O)C1([R])CC(=C2N([AsH-])C(=O)OC23CCCC3)C1</smiles>

493
a: $R^{1}=M e, R^{2}=H \quad 80 \%$
$18 \%$

b: $R^{1}=H, R^{2}=H$

$52 \%$

$44 \%$

c: $R^{1}=R^{2}=M e \quad 40 \%$

$57 \%$

d: $R^{1}=H, R^{2}=M e$

$11 \%$

Scheme 129. 

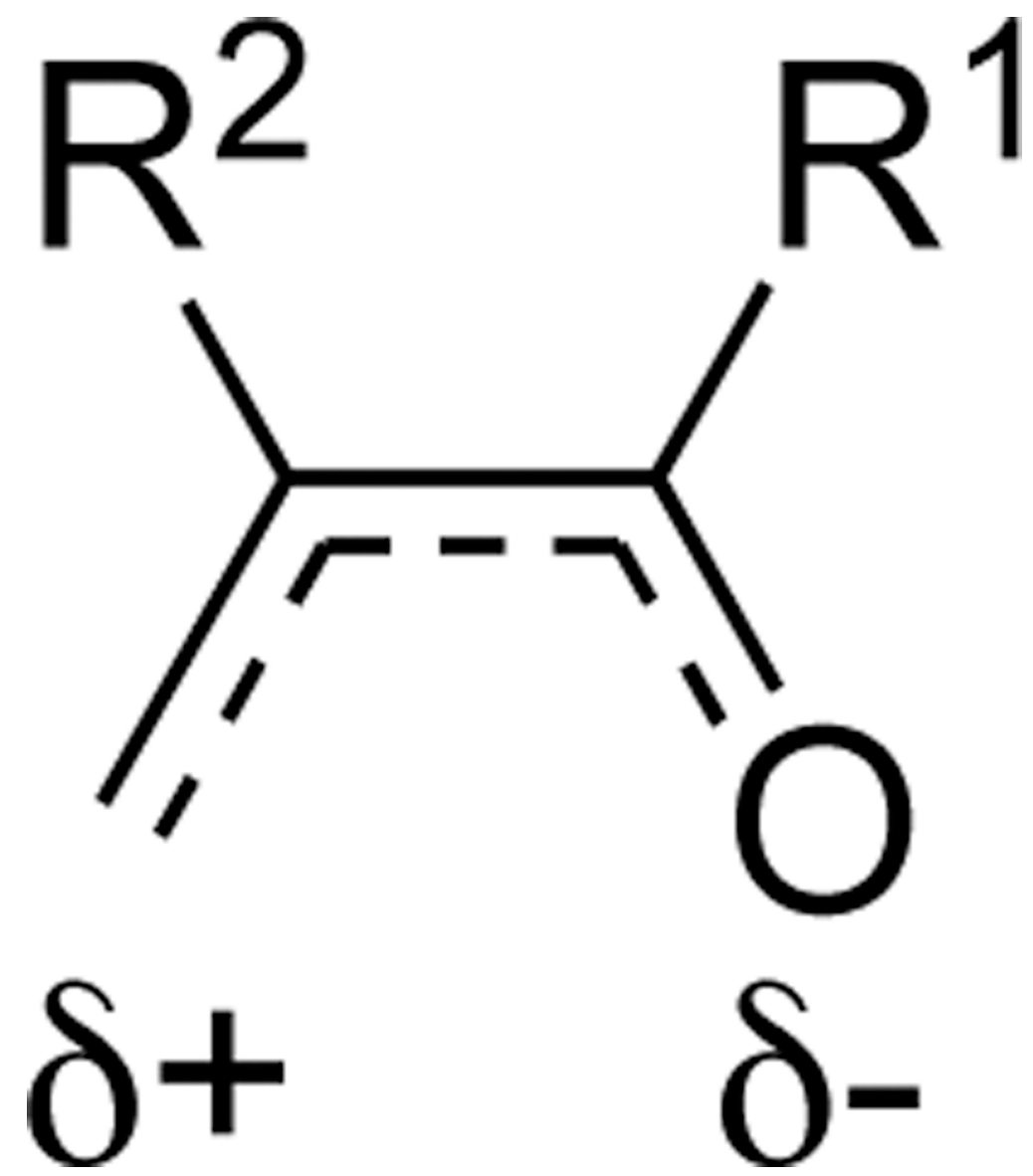

Scheme 130.

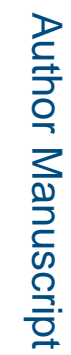




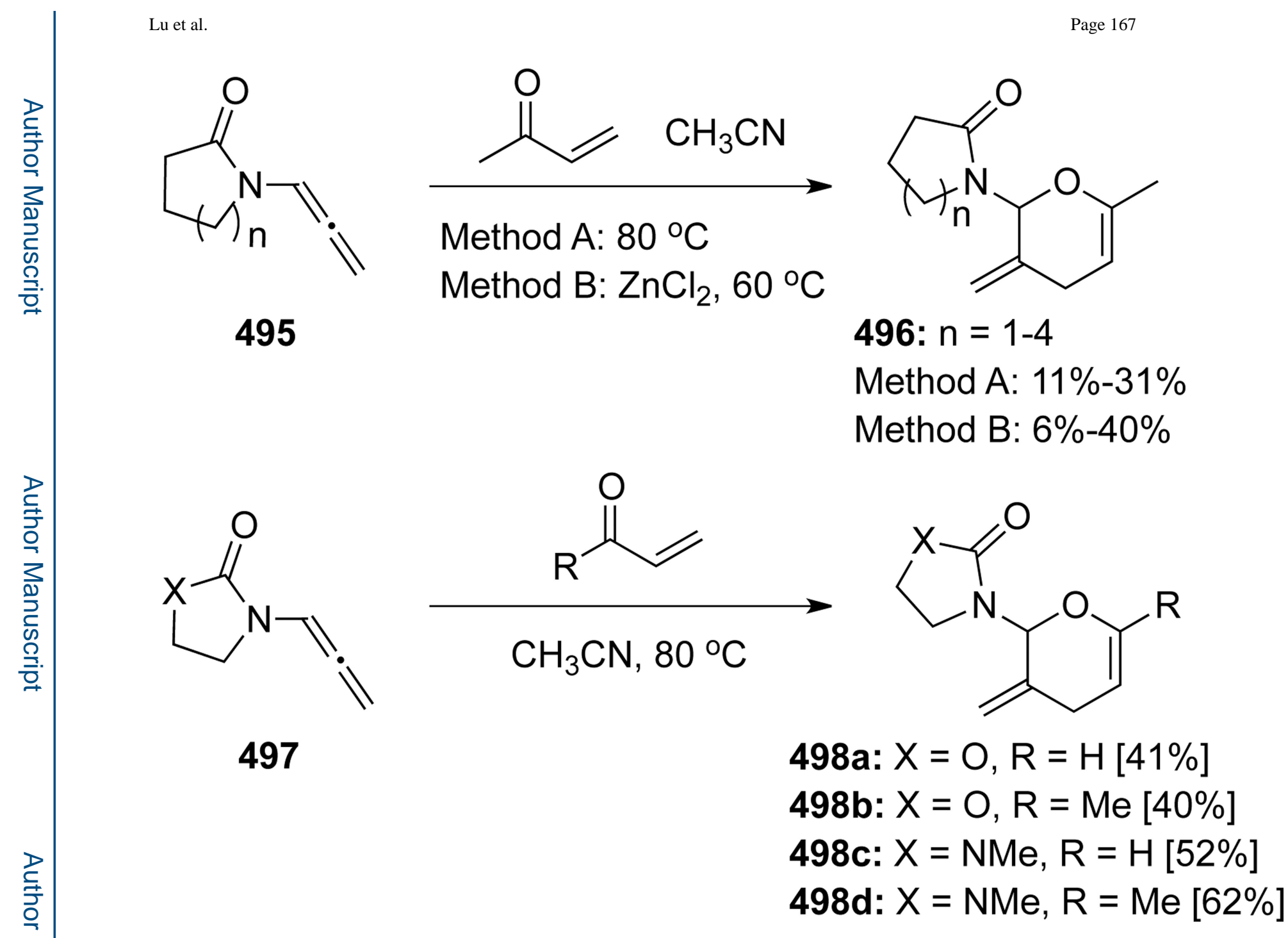

Scheme 131. 
<smiles>[R]C1CC([R2])N(C=C=C)C1=O</smiles>

499<smiles>C=C1CC=CO[C@H]1N1C(=O)N(C)[C@H](C)[C@@H]1P</smiles>

500a: $65 \%$, dr 87:13

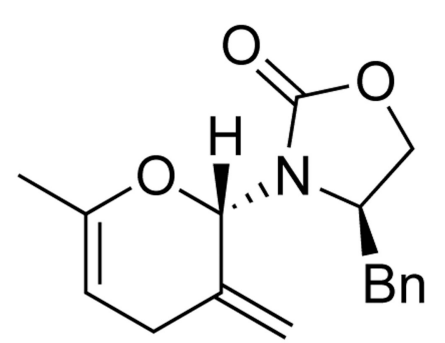

500d: $60 \%$, dr 75:25
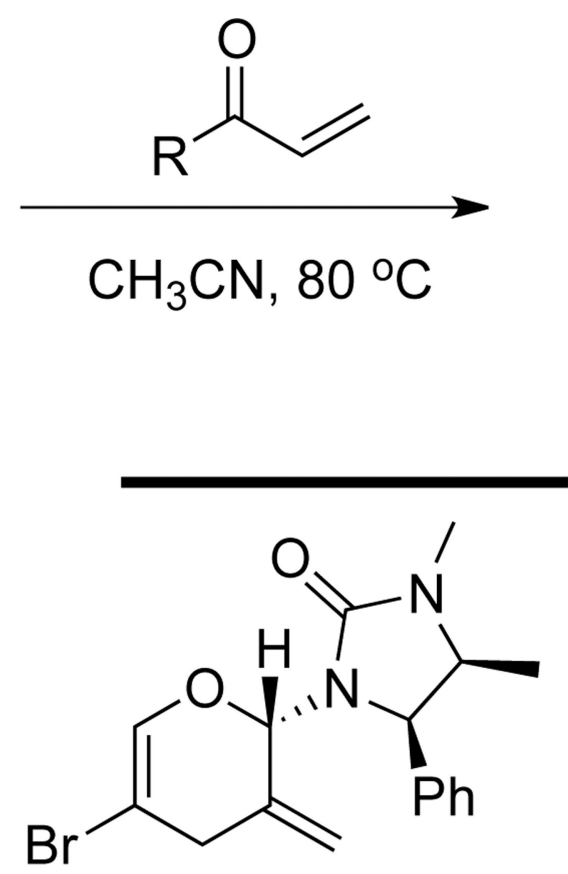

500b: 50\%, $d r 84: 16$<smiles>[X]C(=O)N1[C@@H]2OC([R2])[C@H]1[R2]C([R])=CCC2=C</smiles>

500

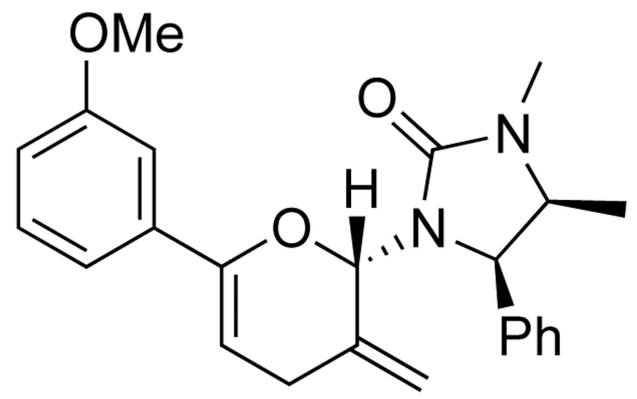

500c: $70 \%, d r \geq 96: 4$

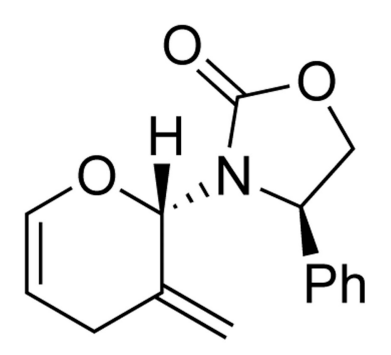

500e: $37 \%$, dr 63:37<smiles>C=C1CC=C(c2cccc3ccccc23)O[C@H]1N1C(=O)N(C)[C@H](C)[C@H]1P</smiles>

500f: $74 \%, d r 94: 6$ Scheme 132. 
<smiles>[R]C1=CCC(=C)[C@H](N2C(=O)N(C)[C@H](C)[C@H]2P)O1</smiles>

500f: $R=1-N a p h$

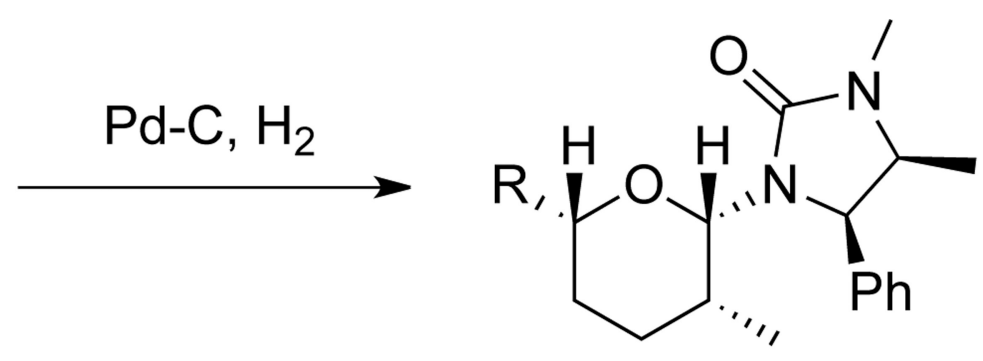

501: $d r \geq 95: 5$

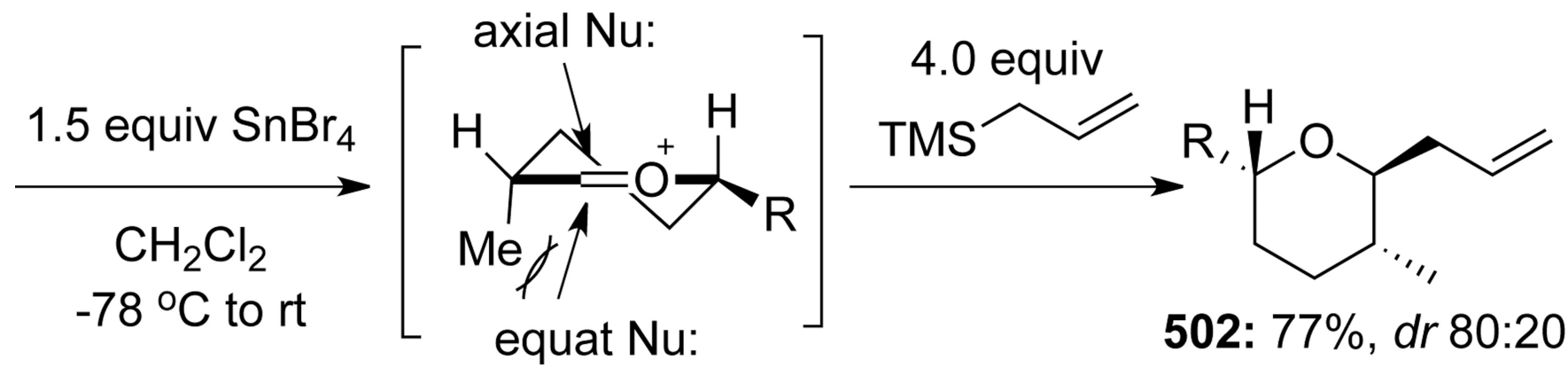

Scheme 133. 
<smiles>[R]C1=CCC(=C)[C@@H](N2C(=O)N(C)[C@H](C)[C@H]2[PH2+])OC1=C(C)C(C)C</smiles>

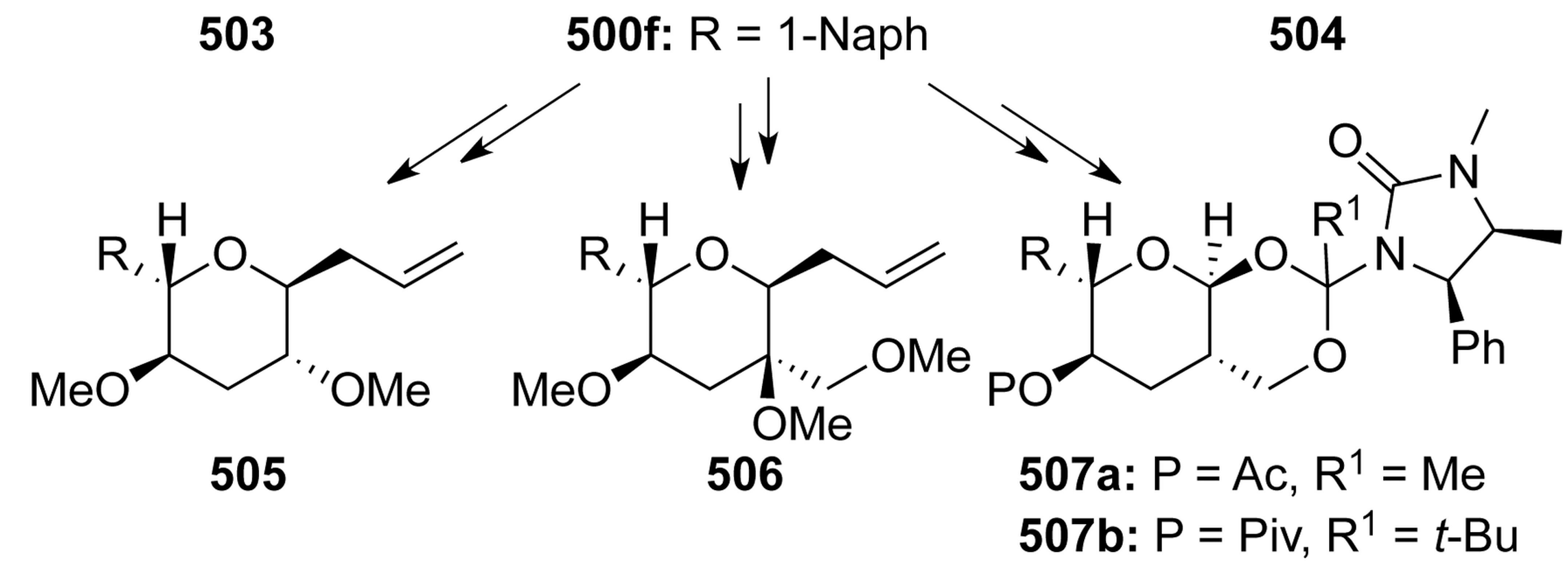

Scheme 134. 
<smiles>C=C(C)C=NS(=O)O</smiles>

508<smiles></smiles>

509

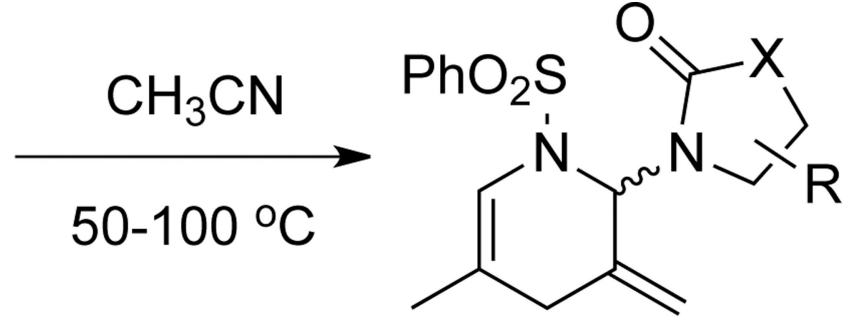

510<smiles></smiles>

510a: 63\%, dr 1:1<smiles>C=C1CC(C)=CN([Pb])[C@H]1N1C(=O)OC[C@H]1P</smiles>

510b: 58\%, $d r 1: 1$ $52 \%$, dr 1.5:1 (PhH)

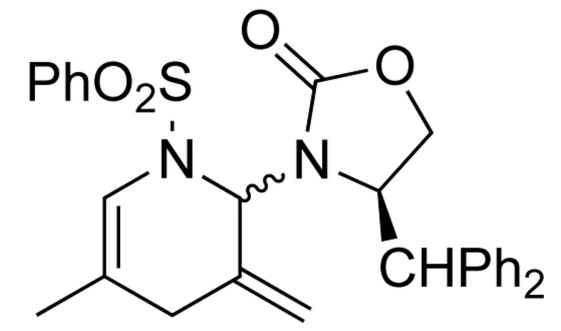

510c: $62 \%, d r 1: 1$

\section{$71 \%$, dr 4.4:1 $\left(\mathrm{CHCl}_{3}\right)$}<smiles>CC1=CN(S(=O)(=O)c2ccccc2)[C@@H]2C(=CC(C)C3N2C(=O)OC3(c2ccccc2)c2ccccc2)C1</smiles>

510d: 53\%, dr 1:1

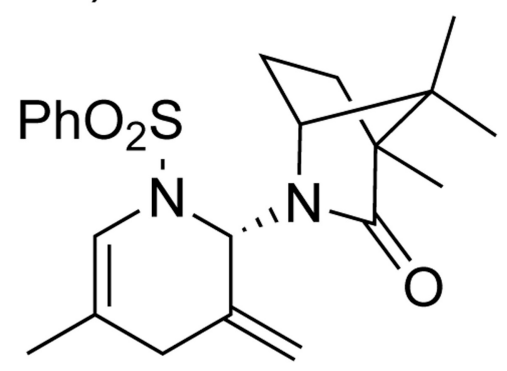

510e: 29\%, dr 3:1

Scheme 135. 
<smiles>[R6]N([SbH2])C=C=C</smiles>

511

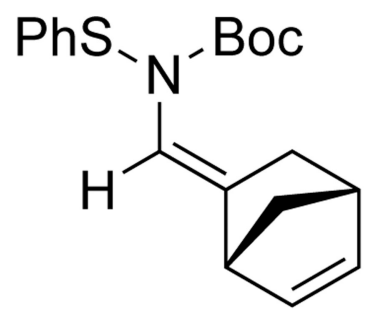

512: $57 \%$
$\mathrm{Cbz} \mathbf{N}^{-\mathrm{PV}}$<smiles>[3H]C=C1C[C@@H]2C=C[C@H]1C2</smiles>

512a: $73 \%$

$\mathrm{Pv}=\mathrm{P}(\mathrm{O})(\mathrm{OEt})_{2}$

Scheme 136. 


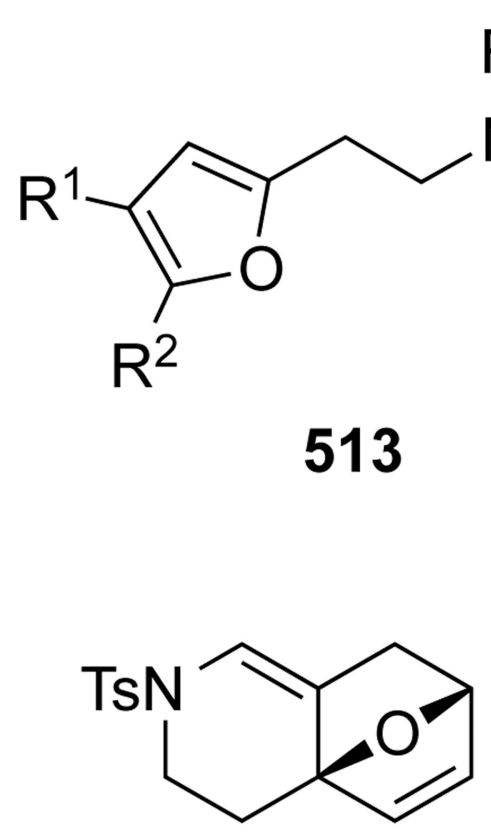

514a: 91\%

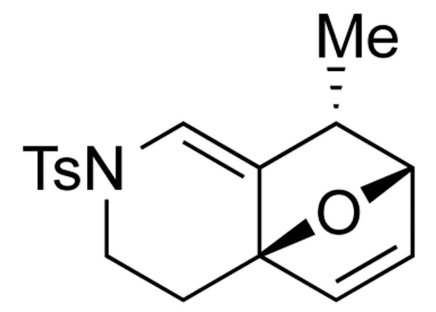

514d: $57 \%, d r$ 3:1

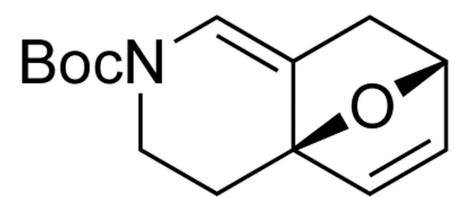

514b: 65\%

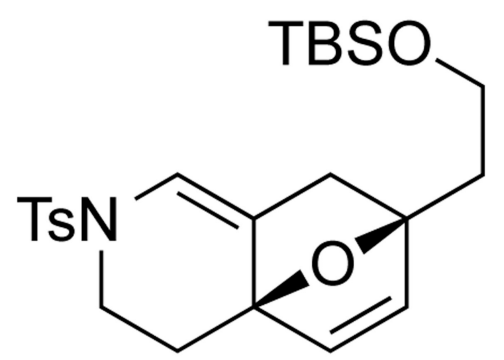

514e: $77 \%$

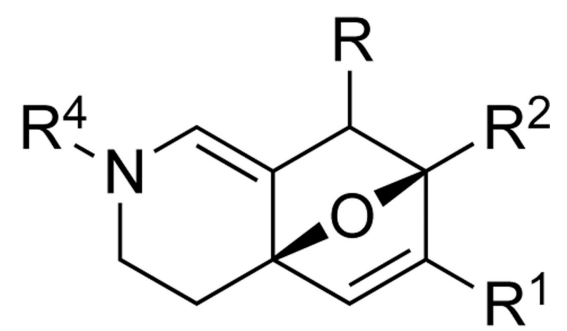

514

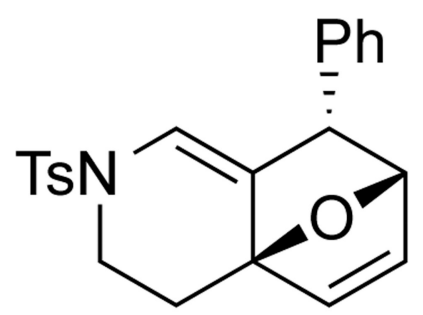

514c: $77 \%$, dr $3: 1$

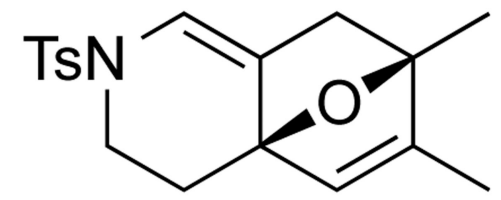

514f: 93\% Scheme 137. 
<smiles>[R]C#CCN(P)CCc1ccc([R7])o1</smiles>
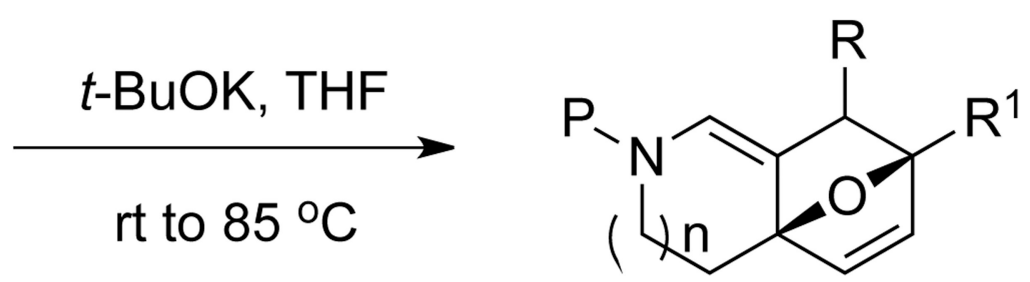

515

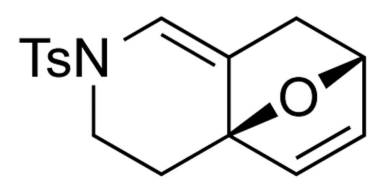

514a: $86 \%$

Scheme 138.

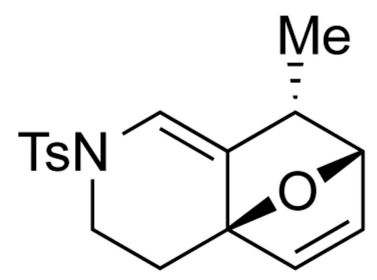

514d: $42 \%, d r 3: 1$ 514e: $63 \%$

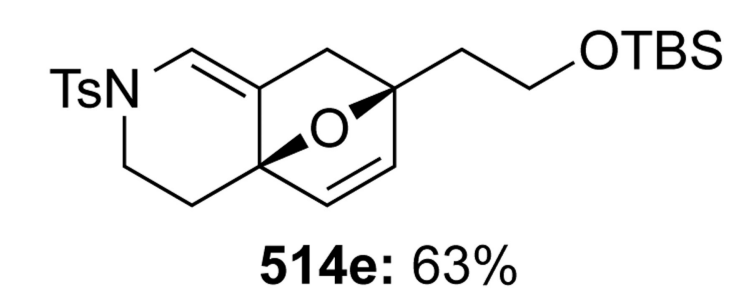

514: $\mathrm{P}=\mathrm{Ts}$ or $p-\mathrm{Ns} ; \mathrm{R}=\mathrm{H}, \mathrm{Me}$ or $\mathrm{Ph}$ $\mathrm{R}^{1}=\mathrm{H}$ or alkyl; $\mathrm{n}=0$ or 1 


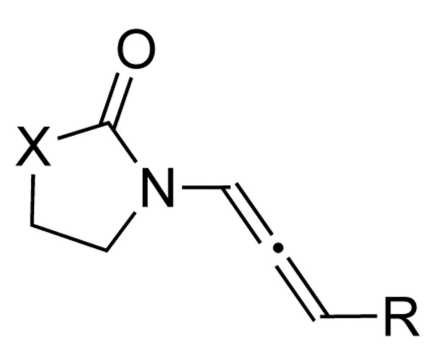

516

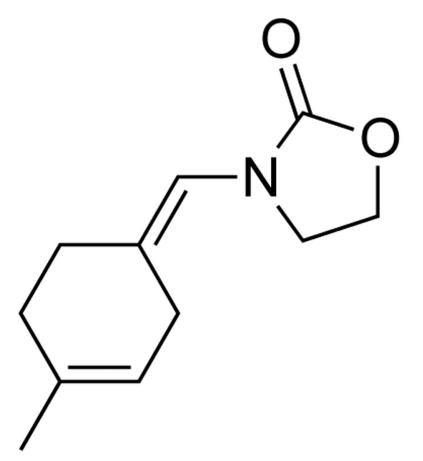

517a: $66 \%, Z: E$ 93:7

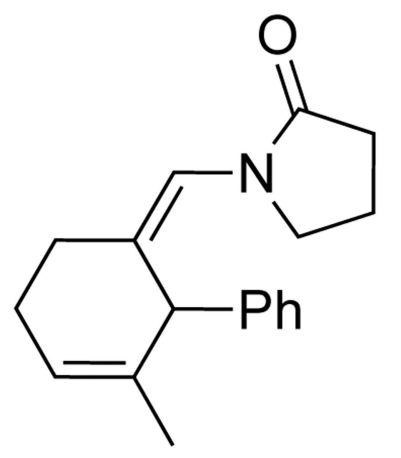

517d: 94\%, Z:E 1:0

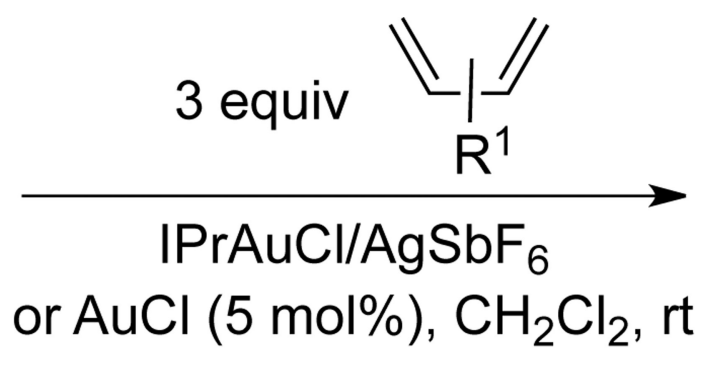

or $\mathrm{AuCl}(5 \mathrm{~mol} \%), \mathrm{CH}_{2} \mathrm{Cl}_{2}$, rt

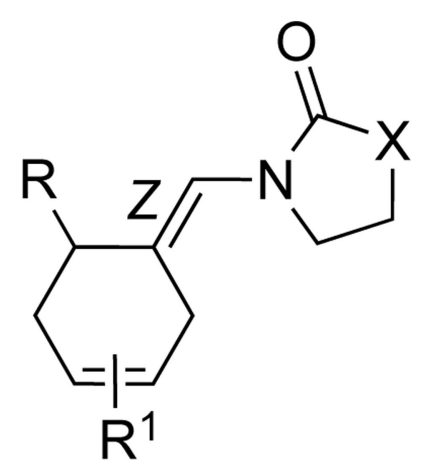

517

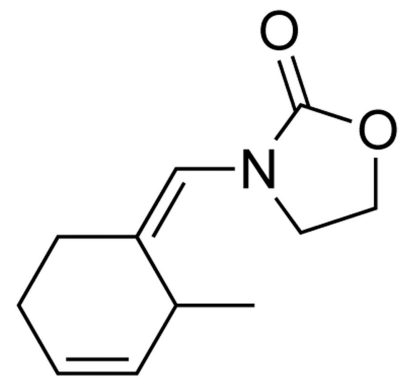

517b: 60\%, Z:E 93:7

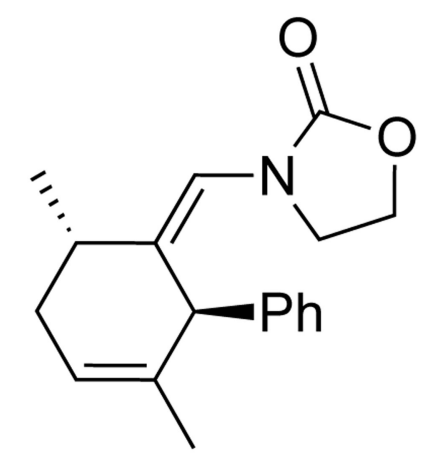

517e: $79 \%, Z: E$ 1:0

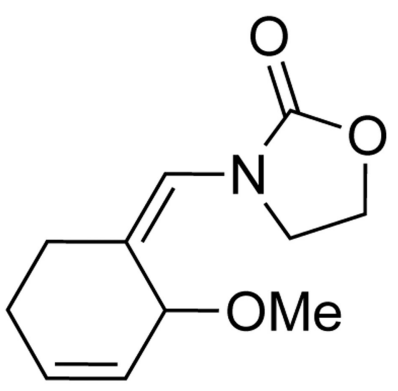

517c: $76 \%, Z: E 1: 0$

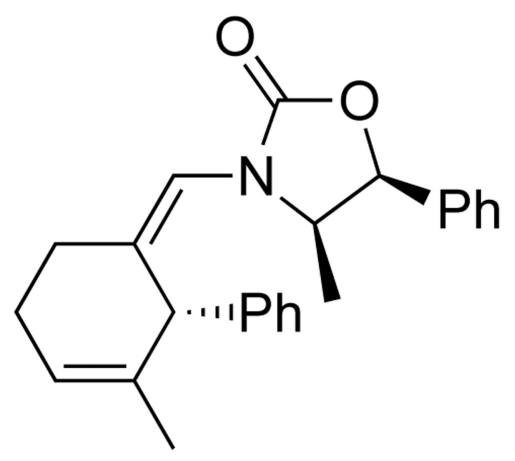

517f: $99 \%$, single isomer

Scheme 139. 


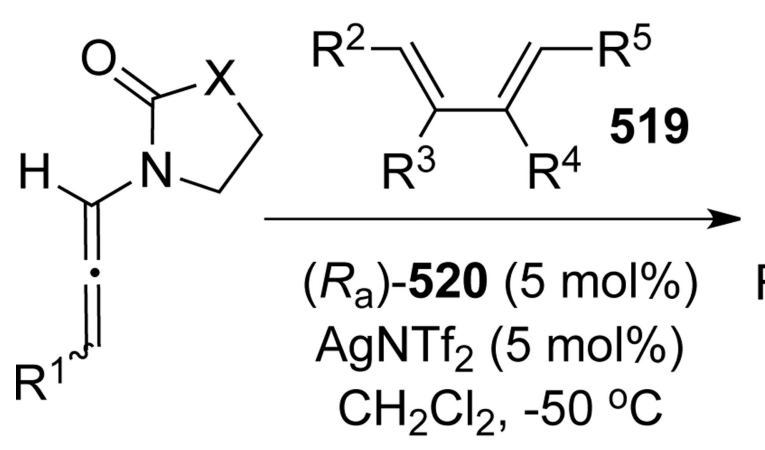

518

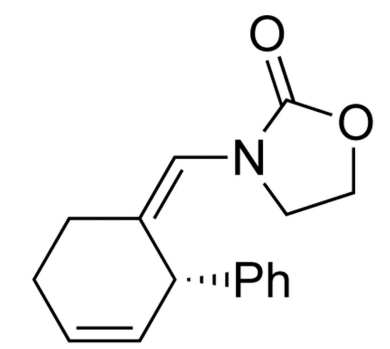

521a: $88 \%$, 99\% ee

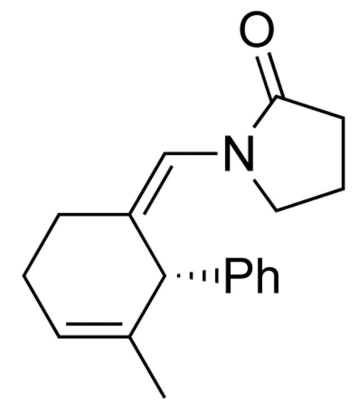

521d: 50\%, 90\% ee

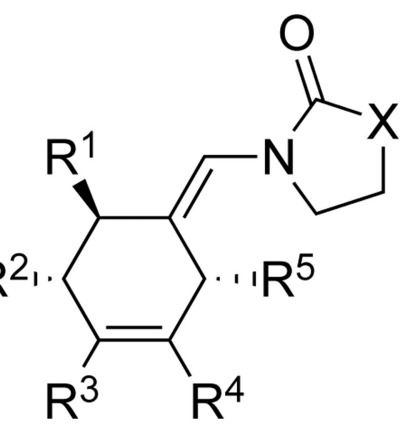

521

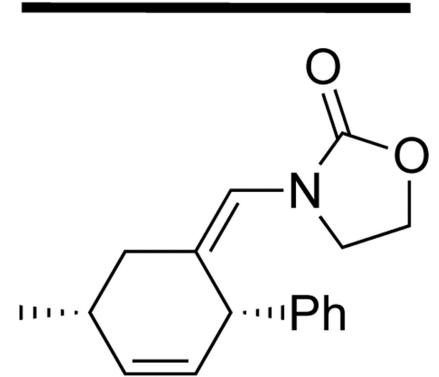

521b: 85\%, 94\% ee

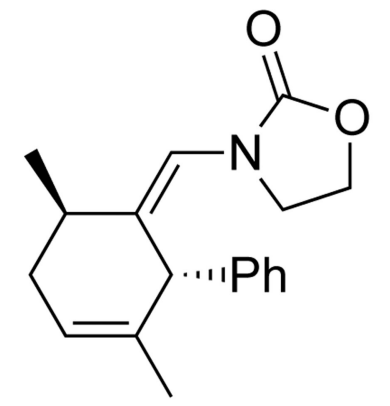

521e: 75\%, $d r 6: 1$ $96 \%$ ee<smiles>[R2]c1ccc2ccccc2c1C1=c2ccccc2=CC2=NN([Al])[C@H](Cl)N21</smiles>

$\left(R_{\mathrm{a}}\right)-520: \mathrm{Ad}=1$-Adamantyl $\mathrm{R}=\mathrm{Me}$ or Cyclohexyl

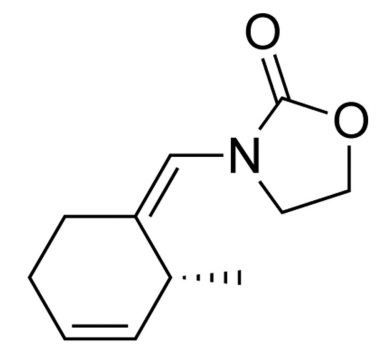

521c: $71 \%, 91 \%$ ee

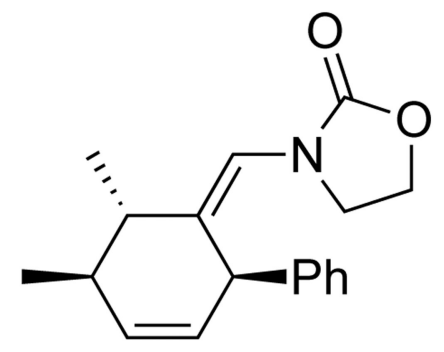

521f: $51 \%, 91 \%$ ee with $\left(S_{a}\right)-520$

Scheme 140. 


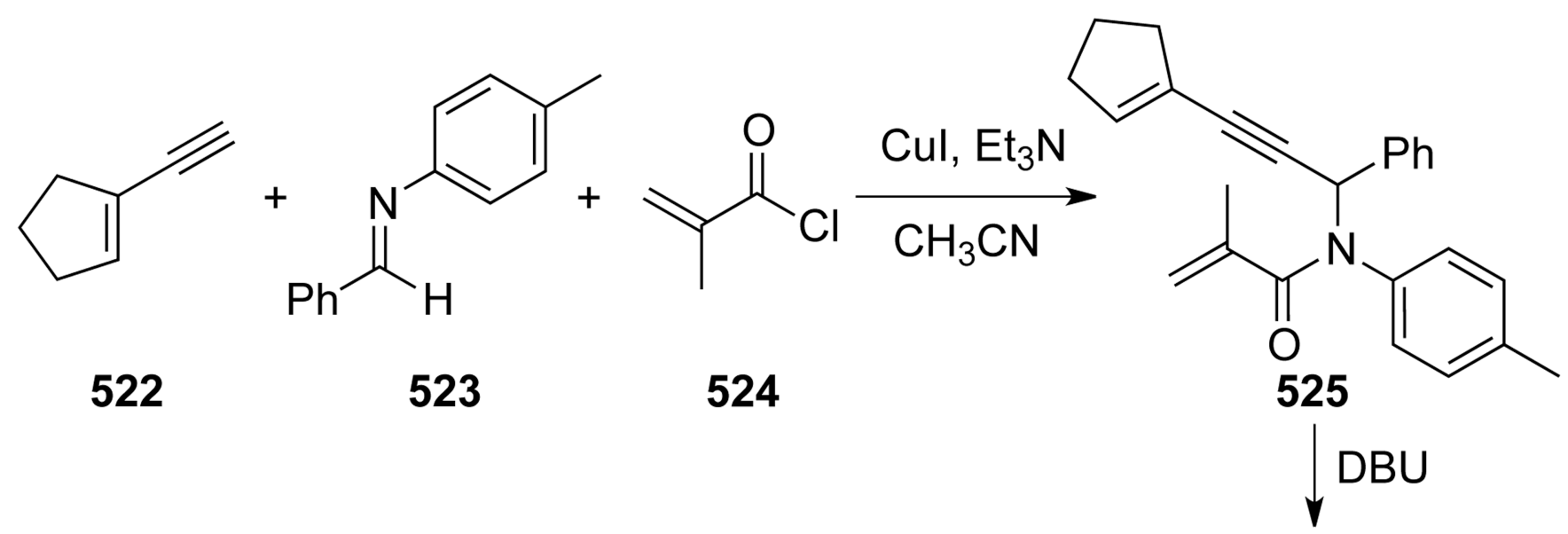<smiles>[Z10]CC(C)C</smiles>

527a: $80 \%$<smiles>C=C(C)C(=O)N(C(=C=CC1=CCCC1)c1ccccc1)c1ccc(C)cc1</smiles>

526

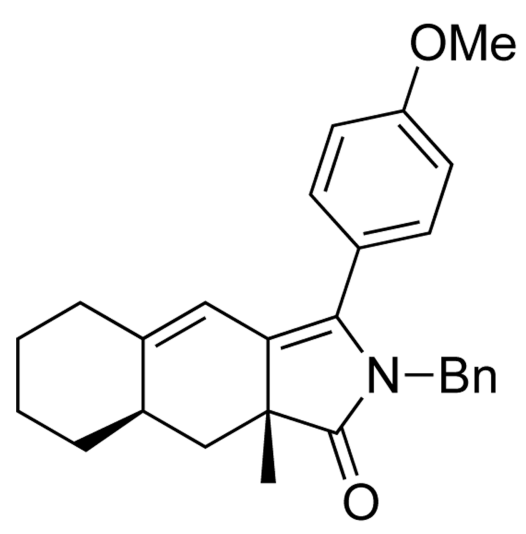

527b: $92 \%$

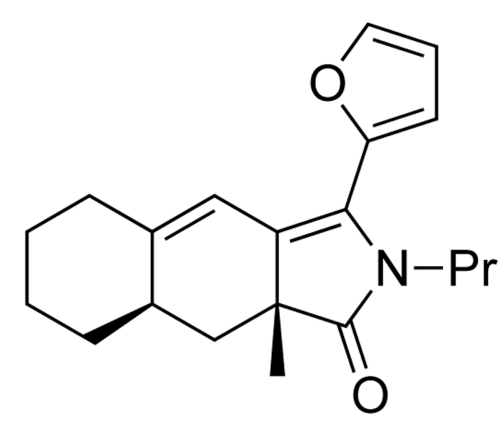

527c: $81 \%$

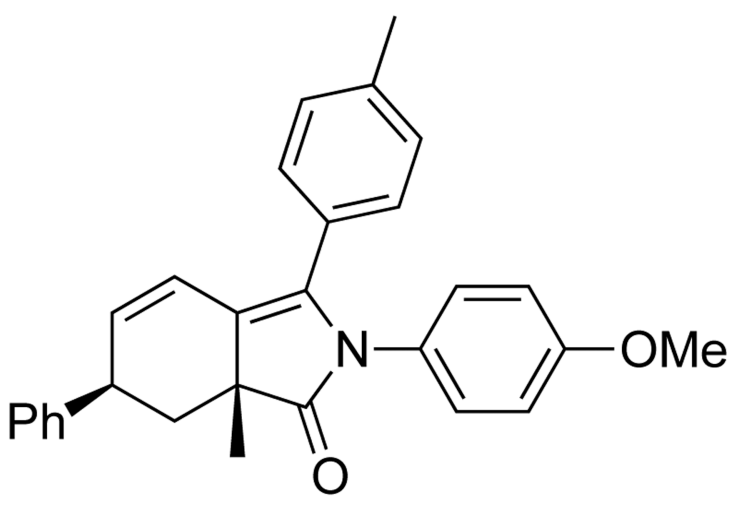

527d: 74\%

Scheme 141. 


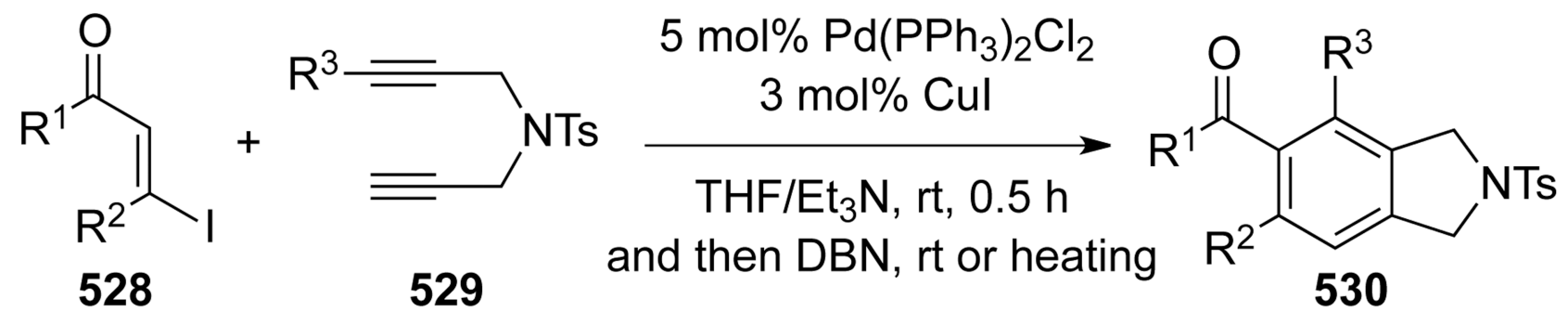

Sonogashira

Coupling

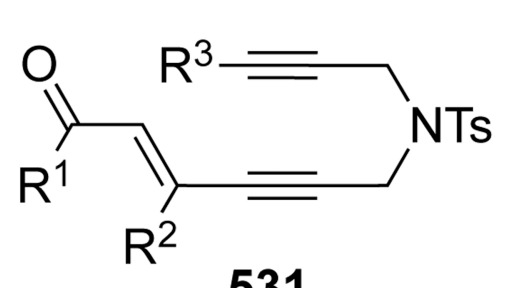

531<smiles>CC1(C)CC(=O)c2c(cc3c(c2-c2ccccc2)CN([S+])C3)C1</smiles>

530a: $72 \%$<smiles>COC(=O)c1ccc2cc3c(c(-c4ccccc4)c2c1)CN(S)C3</smiles>

530d: $62 \%$

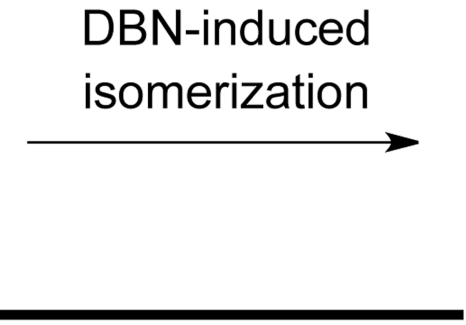<smiles>O=C1CCc2cc3c(c(-c4ccccc4)c21)C[NH+]([S-])C3</smiles>

530b: $62 \%$<smiles>CCCc1c2c(cc3ccc(C(=O)OCC)cc13)CN([S+](=S)[S-])C2</smiles>

530e: 57\%

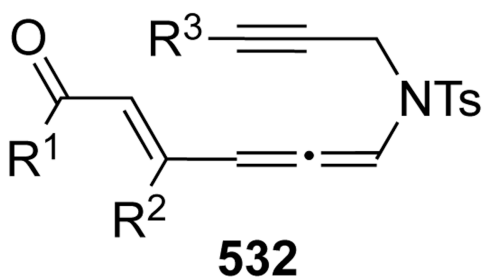<smiles>CCOC(=O)c1ccc2c(c1-c1ccccc1)CN(S)C2</smiles>

530c: $76 \%$

Scheme 142. 


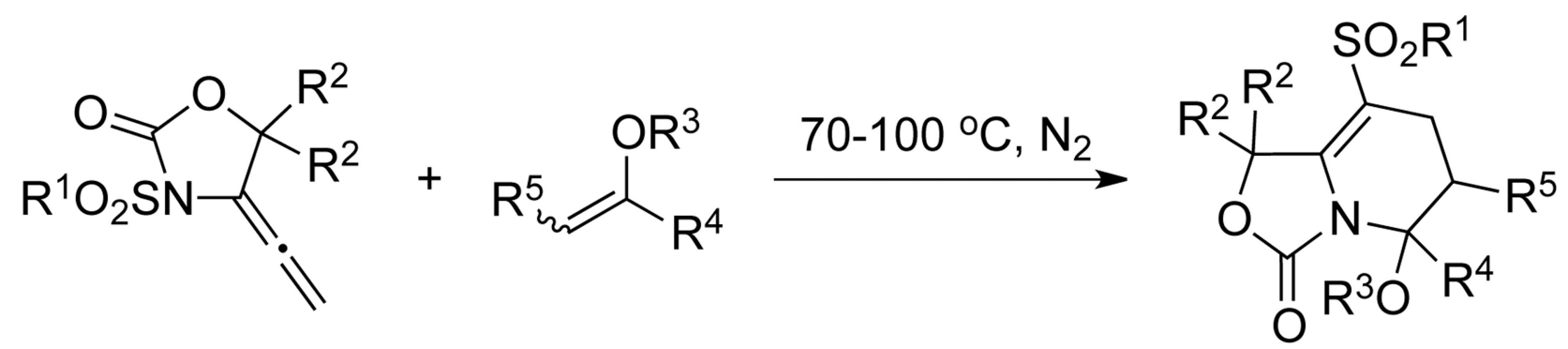

533

534

535

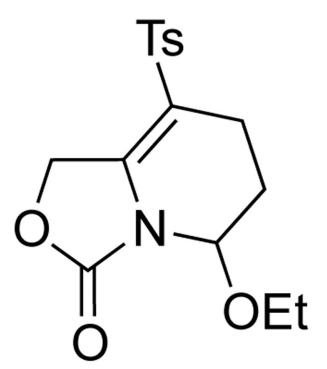

535a: $92 \%$

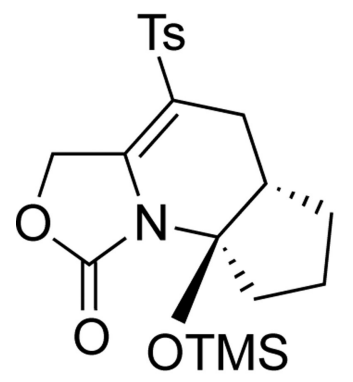

535e: 55\%

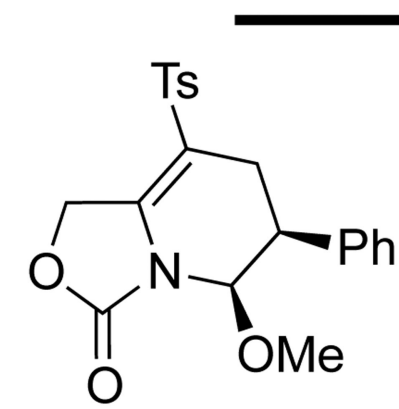

535b: $75 \%$

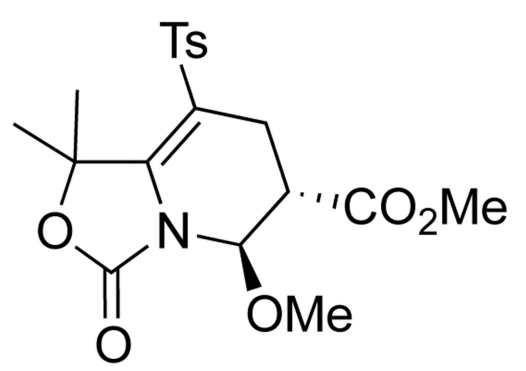

535f: $72 \%$

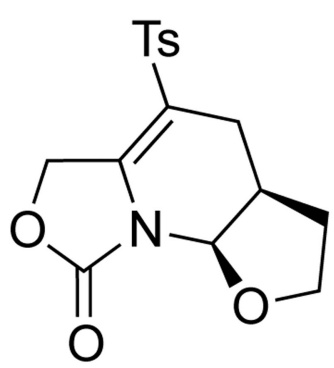

535c: $75 \%$

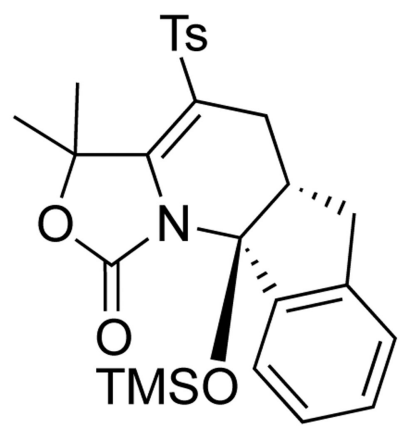

535g: 66\%

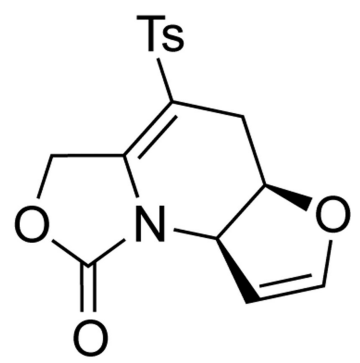

535d: $60 \%$

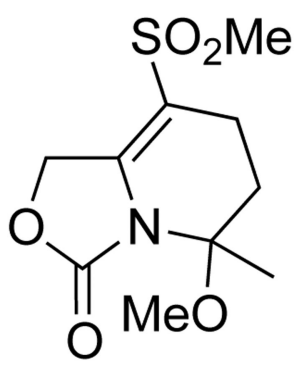

535h: $74 \%$

Scheme 143. 
<smiles>[R]OC=C([R])CC=C1CCC(=C2COC(=O)N2S(=O)(=O)Cl)C1</smiles>

536

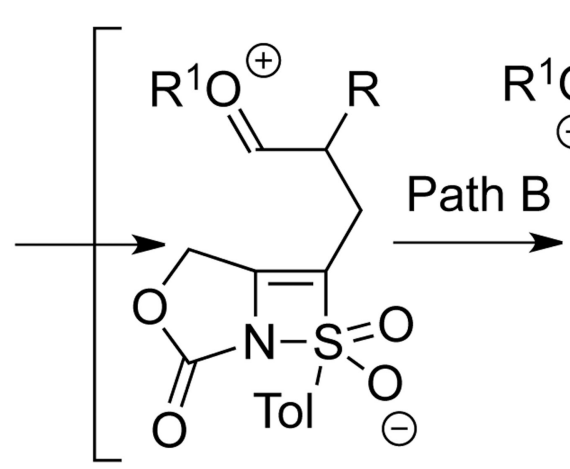

537

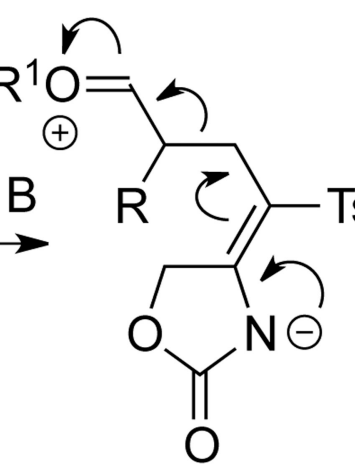

Z-539<smiles>[R]C(C=O)CC([As])=C1COC(=O)N1CC</smiles>

\section{E-539}
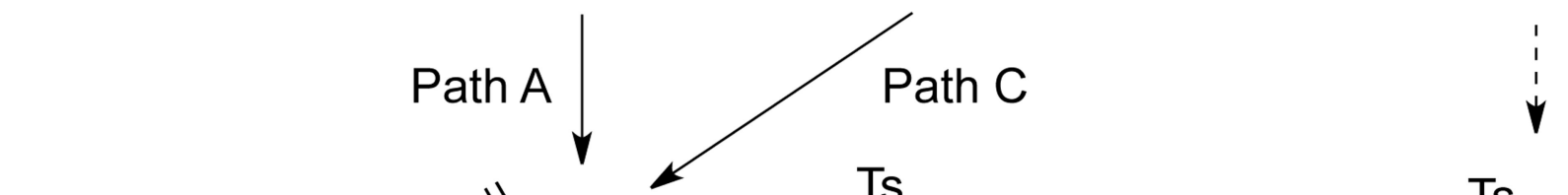<smiles>[R][CH-]C=CO[R]</smiles>

s-cis-538

Z-534

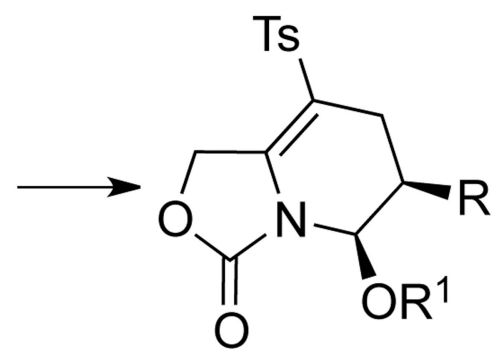

540: cis

Scheme 144. 
Lu et al.

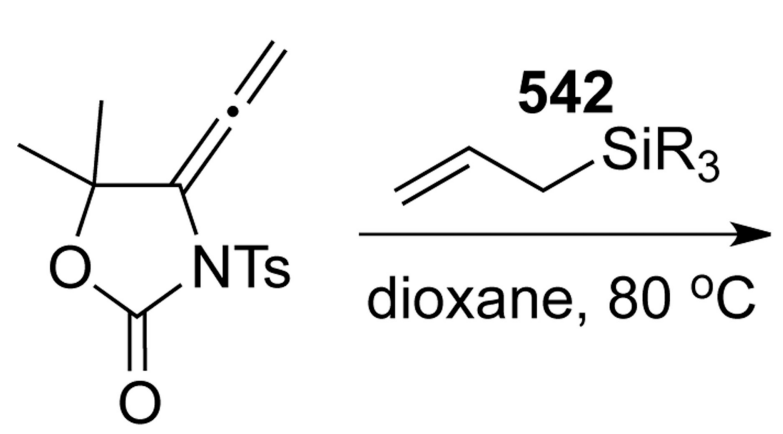

541

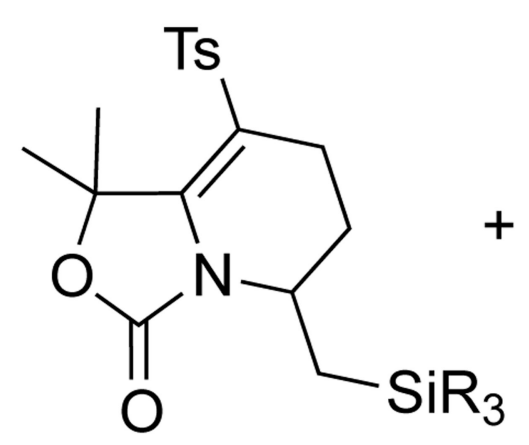

543

542a: $R=M e, 25 \mathrm{~h}$

542b: $\mathrm{R}=i-\operatorname{Pr}, 12 \mathrm{~h}$

542c: $R=P h, 10 h$

542d: $R=O E t, 24 \mathrm{~h}$
$56 \%$

$48 \%$

$40 \%$

0
Page 181

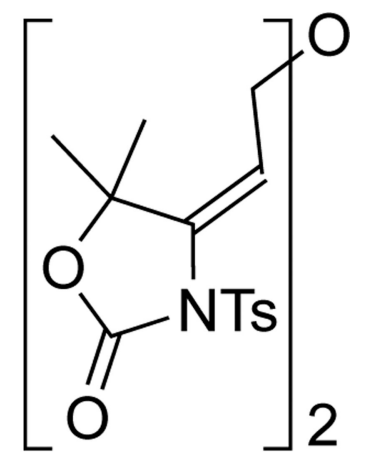

544

$20 \%$

$19 \%$

$10 \%$

nd

Scheme 145. 
<smiles>[R7]C1([R7])OC(=O)N(P)C1=C=C</smiles>

545<smiles>[R7]N1C(=O)OCC12CCc1cc(C)ccc1O2</smiles>

547a: $79 \%$<smiles>Cc1cccc2c1OC1(CC2)COC(=O)N1C(F)(F)F</smiles>

547d: $24 \%$

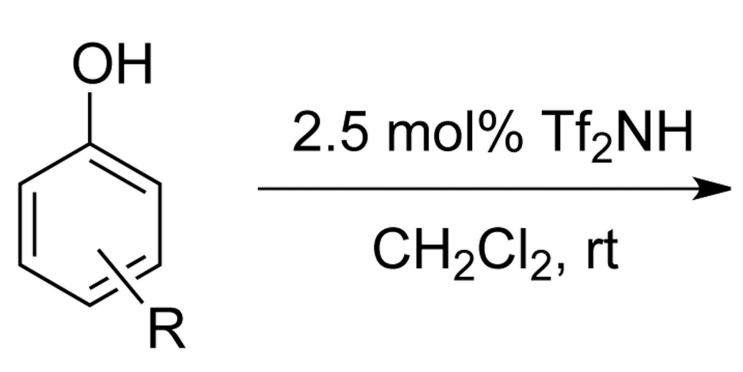

546<smiles>[R]c1cccc2c1OC1(CC2)N(P)C(=O)OC1([R7])[R7]</smiles>

547<smiles>O=C1OCC2(CCc3cc(I)ccc3O2)N1C(F)(F)F</smiles>

547b: $45 \%$<smiles>CN1C(=O)OCC12CCc1ccc3ccccc3c1O2</smiles>

547e: $24 \%$<smiles>O=C1OCC2(CCc3ccc(O)cc3O2)N1[13S]</smiles>

547c: $59 \%$<smiles></smiles>

547f: $73 \%, d r>99: 1$

Scheme 146. 
<smiles>C=C=CN1C(=O)OC[C@H]1Pc1ccccc1</smiles>

548

[O]

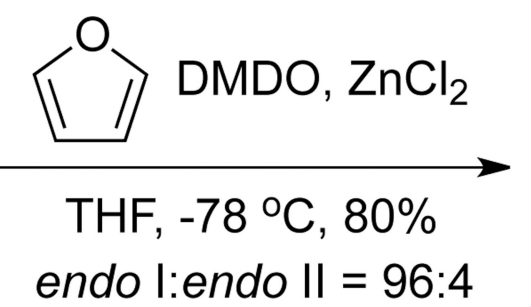

endo I:endo II = 96:4

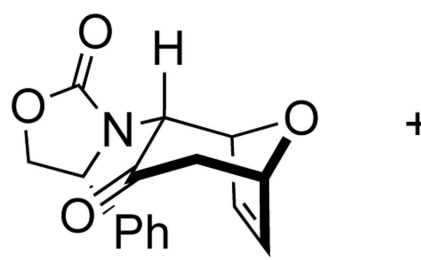

549a: endo-I

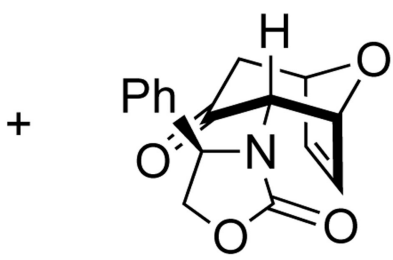

550a: endo-II

But without $\mathrm{ZnCl}_{2}$ :

endo I:endo II = 82:18<smiles>C=C1OC1N1C(=O)OC[C@H]1P(C)OC</smiles><smiles>C=CCOCC</smiles>
nitrogen-stabilized oxyallyl cations<smiles>O=C1OCCN1C1CC2C=CC(C1)C([PH])C2</smiles>

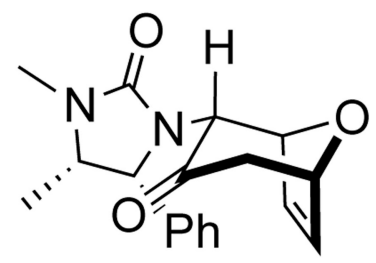<smiles>O=C1OCCN1C1C[C@H]2C=C[C@@H](O2)C1Br</smiles>

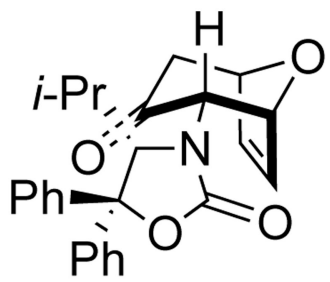

549b: $40 \%$, dr 95:5

$$
\text { 549c: } 60 \% \text {, dr 95:5 549d: 67\%, dr 77:23 549e: 72\%, dr 94:6 }
$$
initially - incorrectly assigned

Scheme 147. 
<smiles>C=C=CN1C(=O)OC[C@H]1Pc1ccccc1</smiles>

548

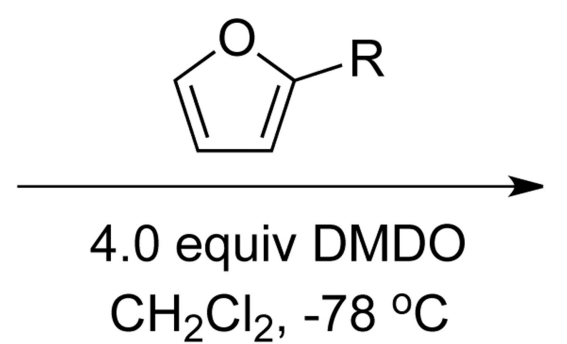

$$
\mathbf{R}=\mathbf{M e}
$$

2.0 equiv $\mathrm{ZnCl}_{2}: 47 \%$ without $\mathrm{ZnCl}_{2}: 54 \%$

$$
\mathbf{R}=\text { COOMe }
$$

2.0 equiv $\mathrm{ZnCl}_{2}: 63 \%$ without $\mathrm{ZnCl}_{2}: 60 \%$

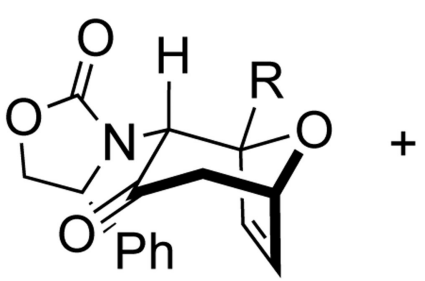

551a: endo-I

95

75

551b: endo-I

30

5

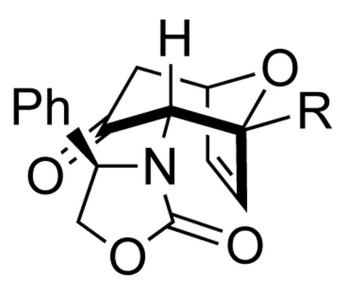

552a: endo-II 5 25

552b: endo-II 70 95 Scheme 148. 


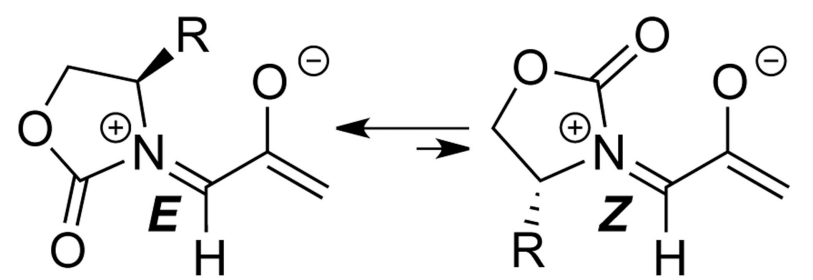

(E)-oxyallyl cation (Z)-oxyallyl cation (preferred)

For $\mathrm{R}=\mathrm{Ph}$ : could not be located

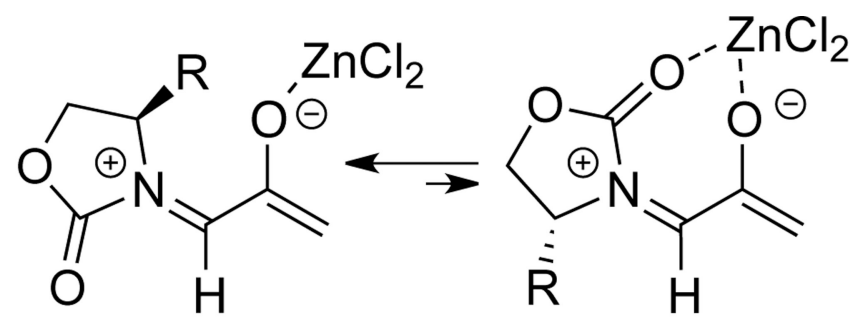

(E)-oxyallyl cation (preferred)
(Z)-oxyallyl cation $\Delta E=6.2 \mathrm{kcal} \mathrm{mol}^{-1}$

Scheme 149. 
$\mathrm{CH}-\pi$ driven/contra sterics

sterically driven
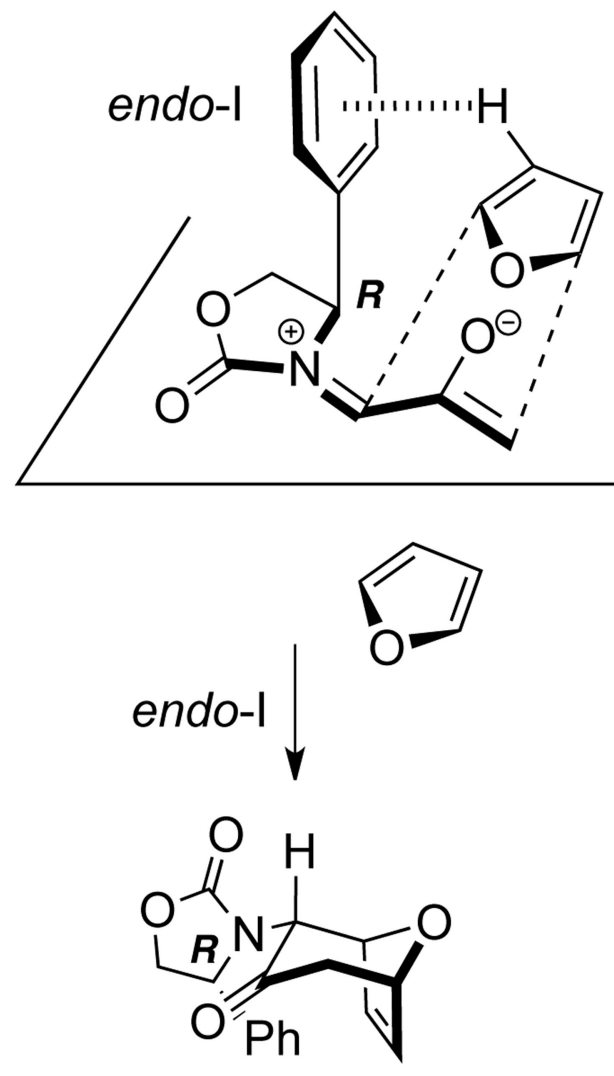

553
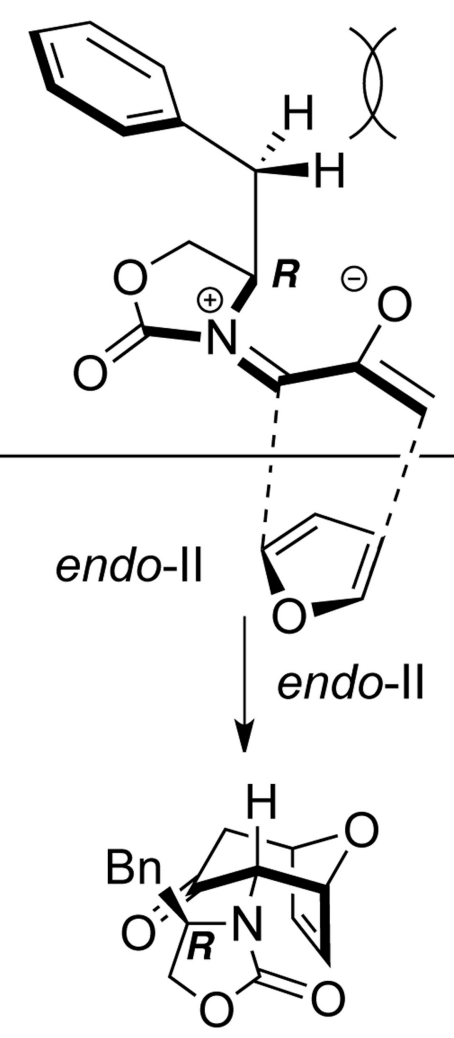

554

endo-I:endo-II = 82:18

endo-I:endo-II = 23:77

$\mathrm{CH}-\pi$ and sterically driven
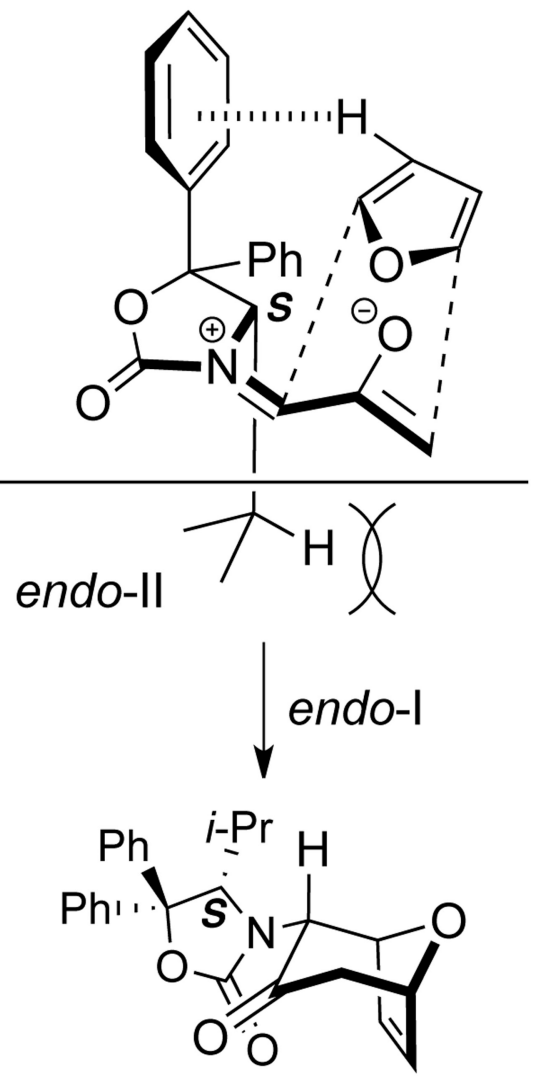

555 Scheme 150. 
<smiles>C=C=CN1CCOC1=O</smiles>

556

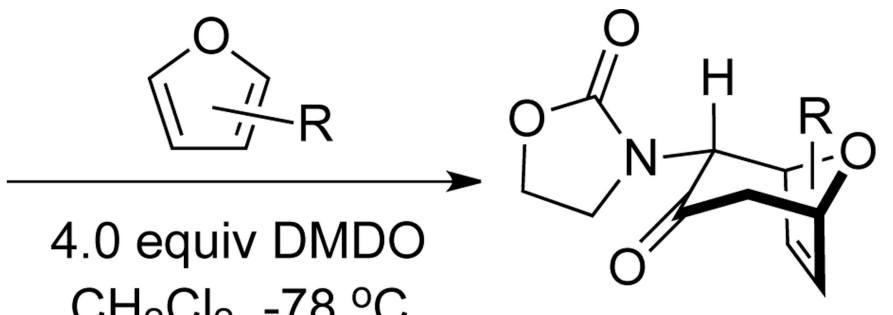

557: syn<smiles>[R][C@H]1C=C[C@@H]2O[C@H]1[C@@H](N1CCOC1=O)C2=O</smiles>

557: anti<smiles>CC1(C)[C@@H]2CC[C@H]1C(=O)O2</smiles>

557a: major syn no additive: $90 \%, 83: 17$ $\mathrm{ZnCl}_{2}: 97 \%, 86: 14$<smiles>CCOC(=O)C1=CC2OC(C1OCC)C(N1CCOC1=O)C2=O</smiles>

557d: major anti no additive: $36 \%$, 9:91 $\mathrm{ZnCl}_{2}: 53 \%, 9: 91$

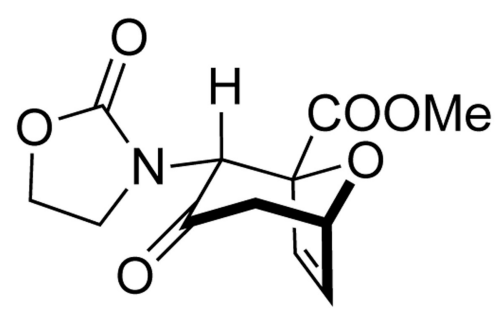

557b: major syn no additive: $41 \%, \geq 95: 5$ $\mathrm{NaClO}_{4}: 67 \%, \geq 95: 5$<smiles>COC[C@H]1O[C@@H]2CC(C)[C@H](C(=O)O2)[C@H]1N1CCOC1=O</smiles>

557e: major syn $\mathrm{ZnCl}_{2}: 65 \%$, $\geq 95: 5$

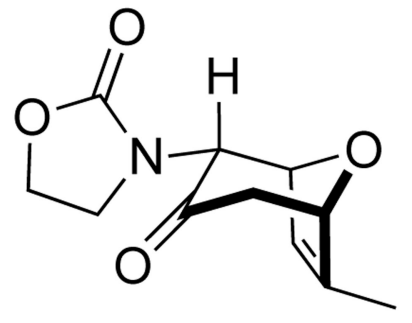

557c: major anti no additive: 95\%, 13:87 $\mathrm{ZnCl}_{2}: 96 \%, 22: 78$

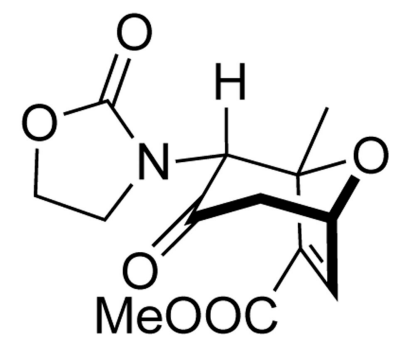

557f: major syn $\mathrm{ZnCl}_{2}: 56 \%$, $\geq 95: 5$

Scheme 151. 
D: electron donating: a steric model less hindered attack
$\mathbf{W}$ : electron withdrawing: an electronic model conjugate addition like

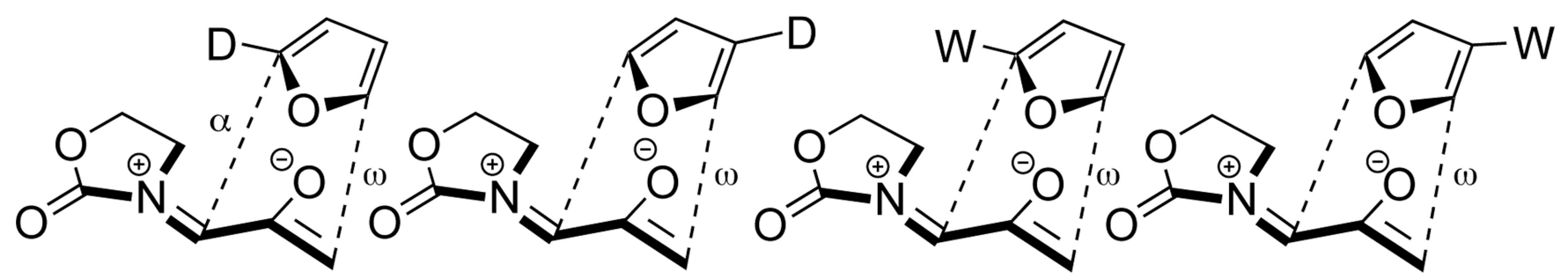

syn: favored

anti: favored

syn: favored

anti: favored nitrogen-stabilzed oxyallyl cations: ambiphilic $w / H O M O=$ enolate-like

Scheme 152. 
<smiles>C=C=CN1C(=O)OC[C@H]1Pc1ccccc1</smiles>

548

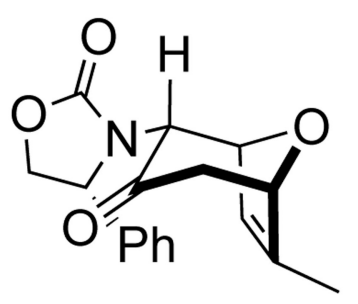

558a: $62 \%, 88: 12$

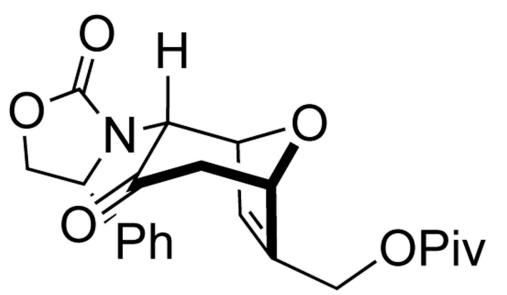

558d: $53 \%$, single isomer

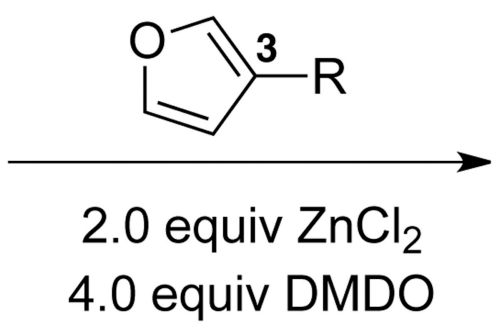

$\mathrm{CH}_{2} \mathrm{Cl}_{2},-78^{\circ} \mathrm{C}$

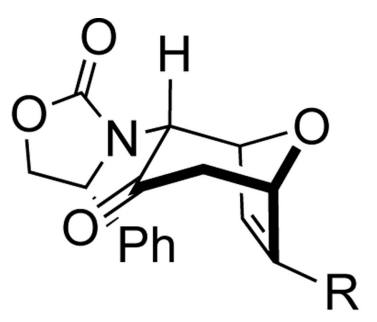

558: major anti-endo-I

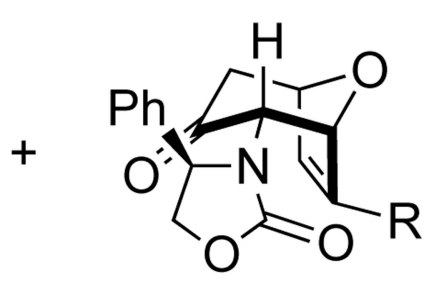

559: minor syn-endo-II

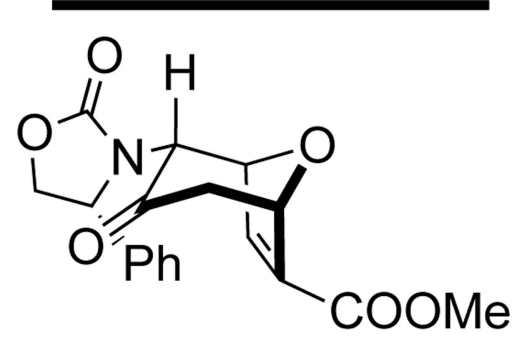

558b: 60\%, 90:10

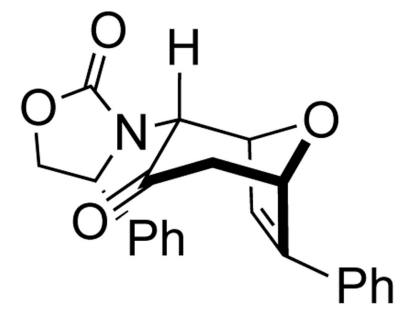

558e: $50 \%, 60: 40$

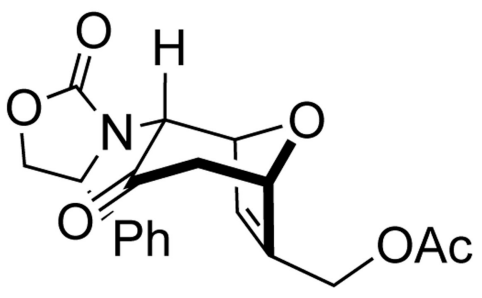

558c: $49 \%, 70: 30$

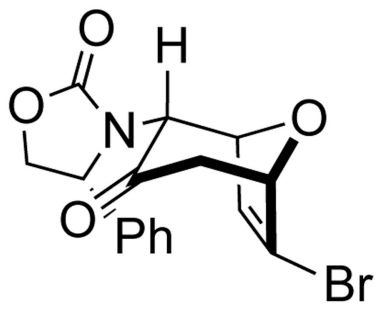

Scheme 153. 
<smiles>C=C=CN1C(=O)OC[C@H]1P</smiles>

548

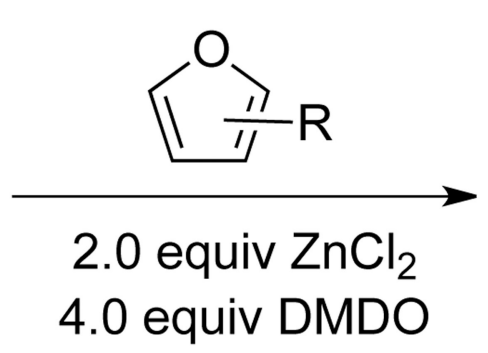

$\mathrm{CH}_{2} \mathrm{Cl}_{2},-78^{\circ} \mathrm{C}$

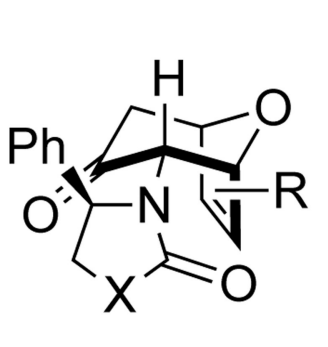

560: syn-endo-II
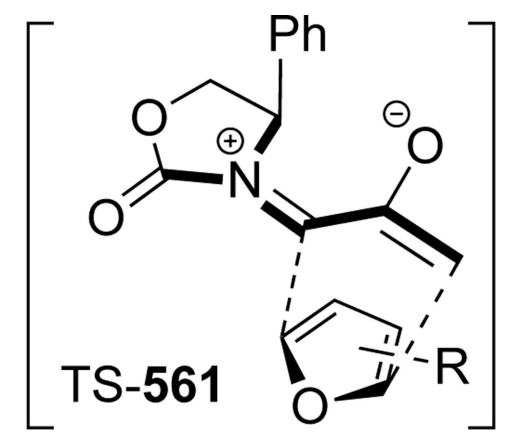

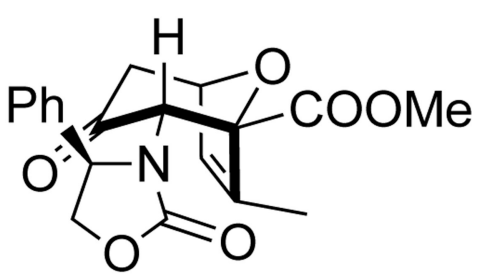

560a: $67 \%$

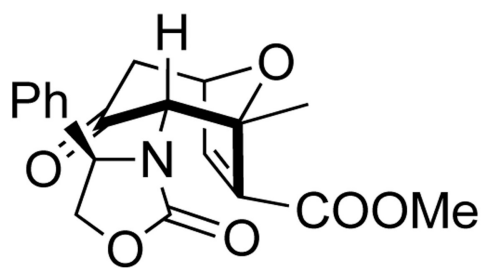

560b: $60 \%$

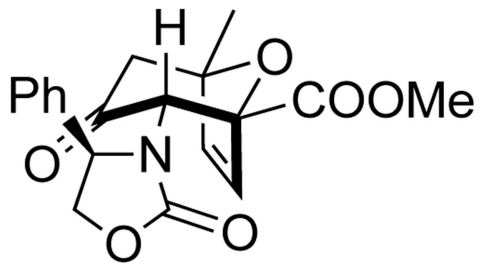

560c: $40 \%$ 
<smiles>[R]CN(C=C=C)C(=O)OCCS(=O)(=O)O</smiles>

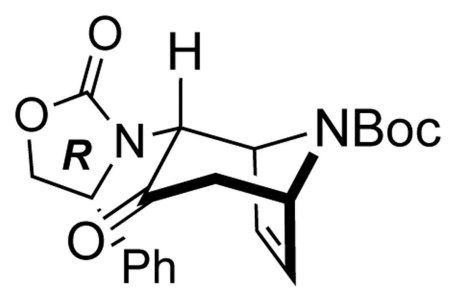

563a: $76 \%$, I:II = 82:18

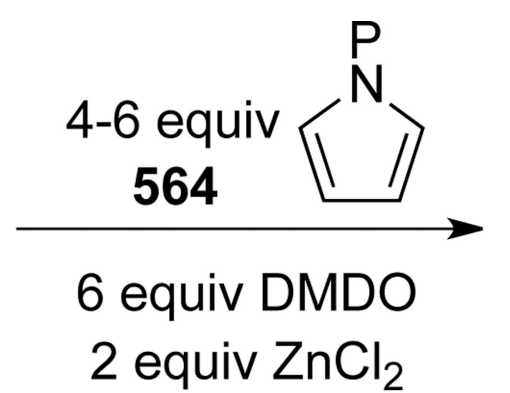

$4 \AA \mathrm{MS}, \mathrm{CH}_{2} \mathrm{Cl}_{2}$<smiles>[R]CN1C(=O)OC[C@@H]1C1CC[C@@H]2CC[C@H]1N2</smiles>

563: endo-I

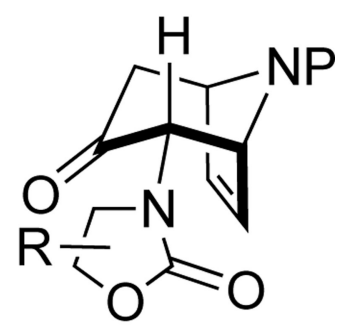

563: endo-II

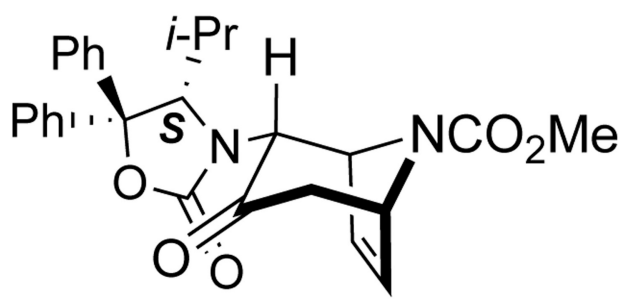

563b (revised): 61\% l: $I I=5: 95$

Scheme 155. 


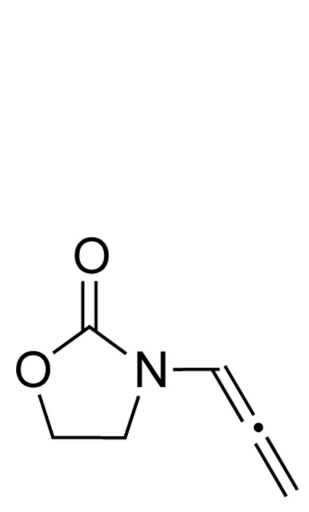

556

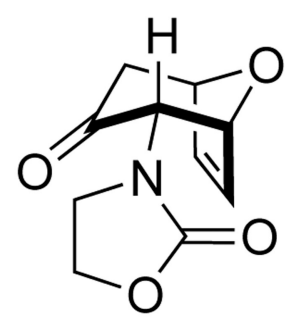

566a: 91\%, $99 \%$ ee<smiles>C[C@H]1N=C(C(C)(C)C2=N[C@@H](c3ccccc3)C(O)O2)OC1c1ccccc1</smiles>

$\mathrm{Ph}$
25 mol\% $\mathrm{CuOTf}_{2}, 9.0$ equiv diene 2-5 equiv DMDO, $4 \AA$ MS additive, acetone $/ \mathrm{CH}_{2} \mathrm{Cl}_{2}$

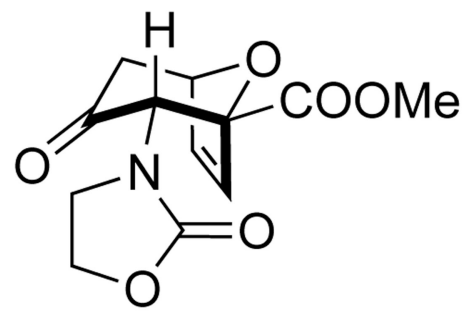

S-557b: $61 \%$, $67 \%$ ee, syn only

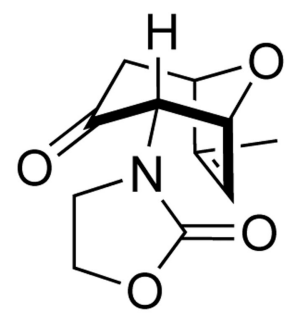

S-557c: $91 \%$, $99 \%$ ee, anti only

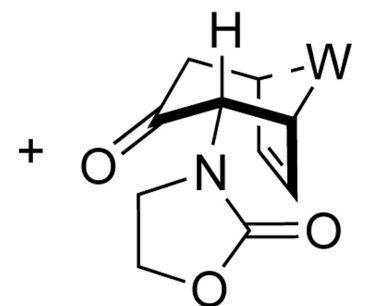

anti-566

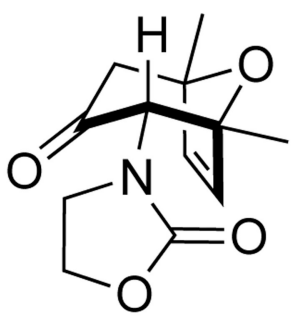

566b: $81 \%$, $36 \%$ ee

Scheme 156. 


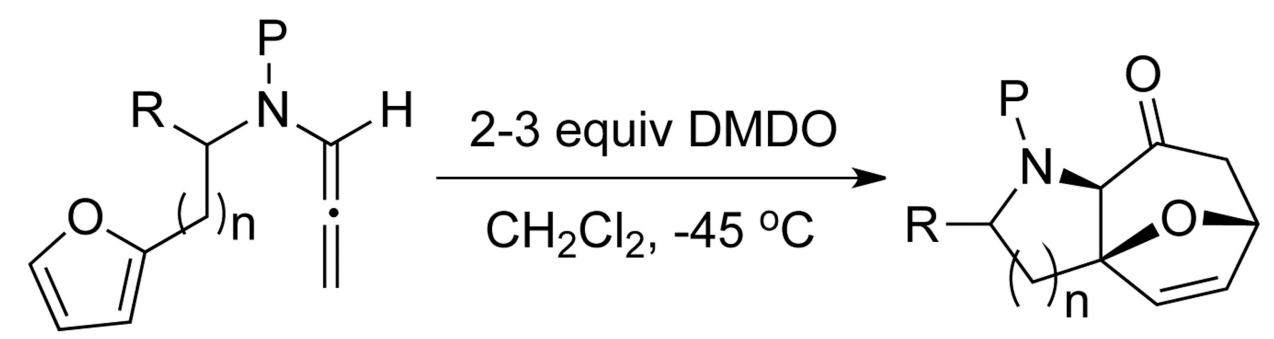

567

568

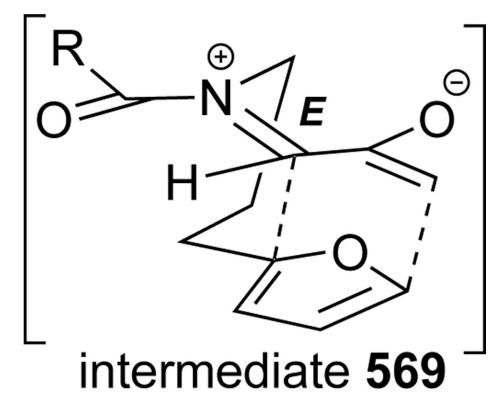

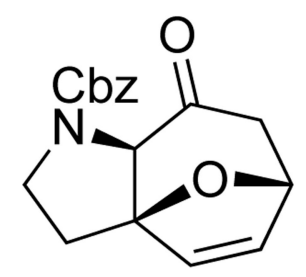

568a: $75 \%$

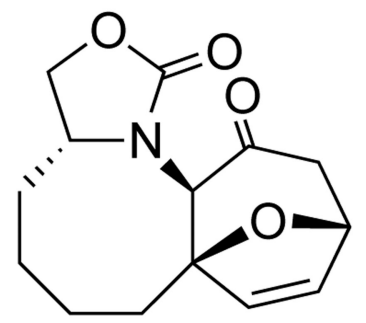

568d: $57 \%, d r 70: 30$

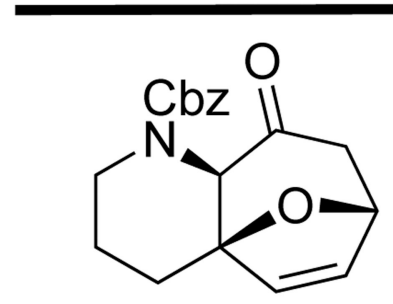

568b: $47 \%, d r 60: 40$

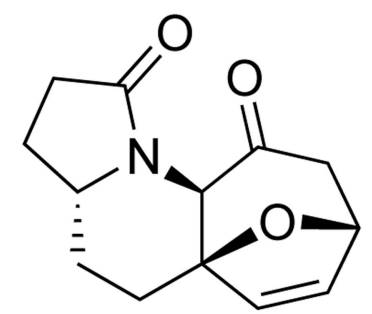

568e: $90 \%, d r 87: 13$

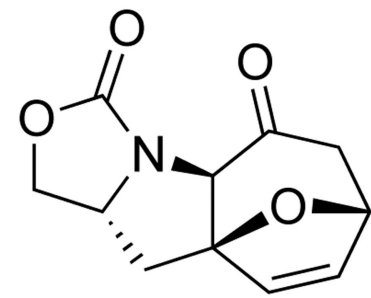

568c: $82 \%, d r 96: 4$

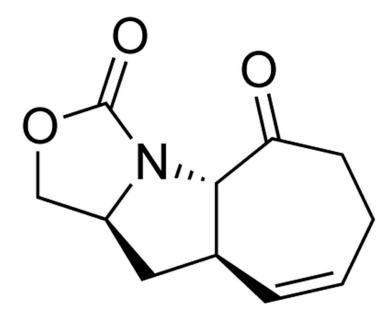

568f: $75 \%, d r 62: 38$

Scheme 157. 


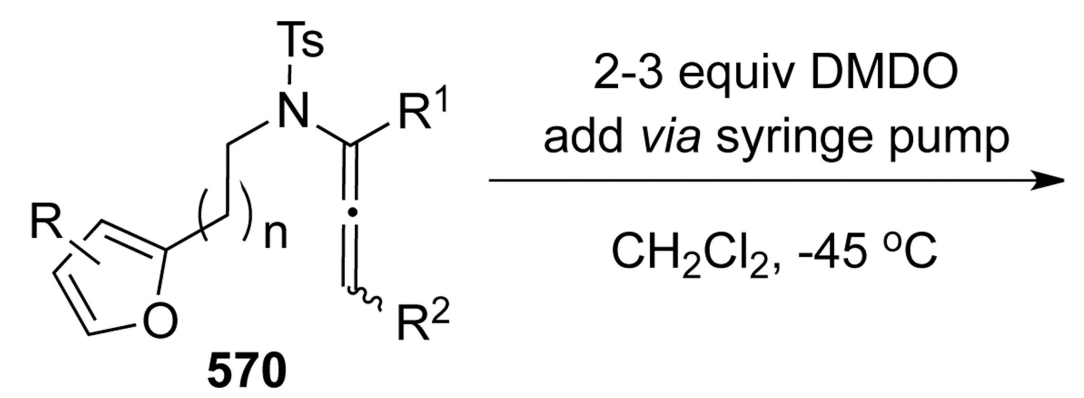

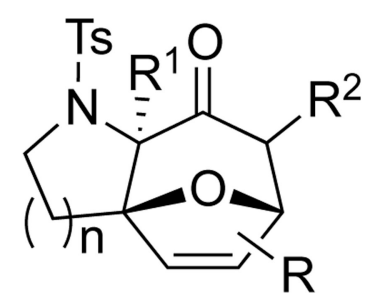

571

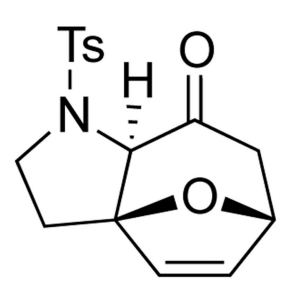

571a: 98\%

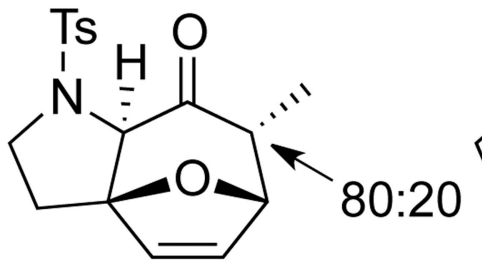

571b: 93\%

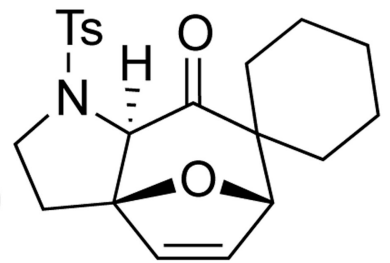

571c: $90 \%$

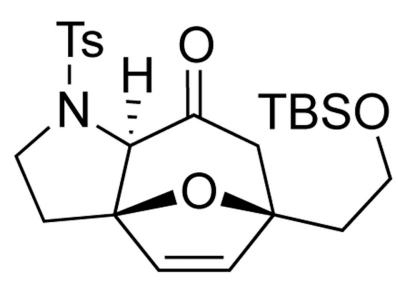

571d: 97\%
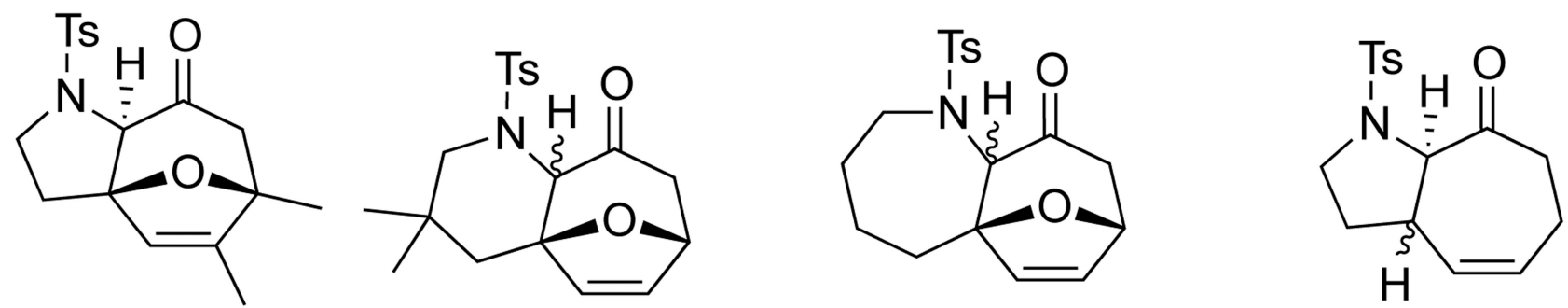

571e: $<5 \% \quad$ 571f: $64 \%$, $d r 90: 10 \quad$ 571g: 17\%, dr 90:10 571h: 73\%, dr 75:25 Scheme 158. 


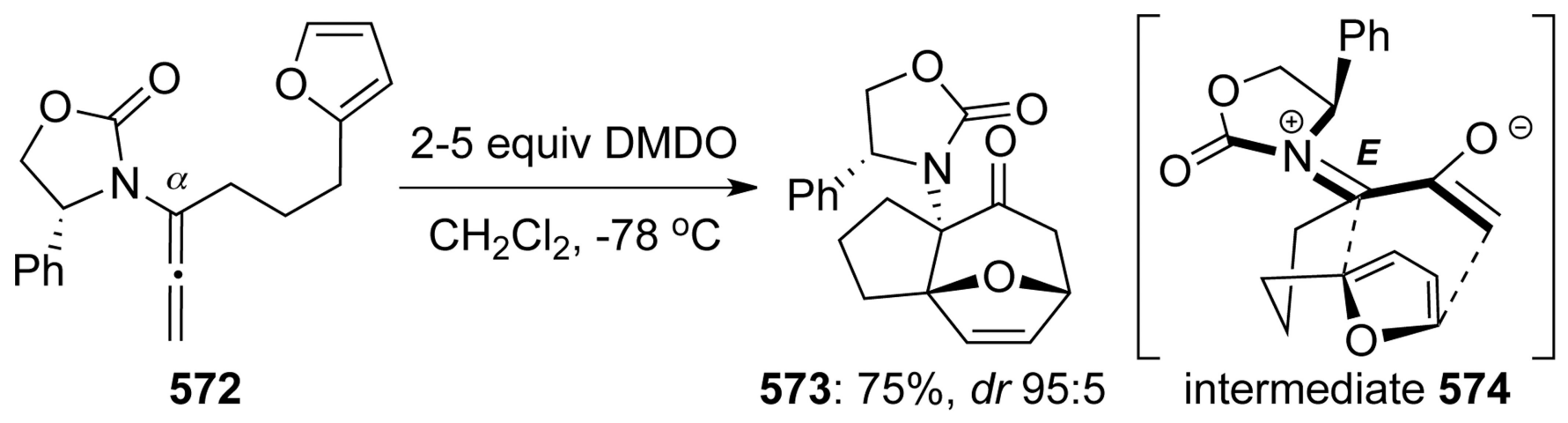<smiles>CCO[C@@H](C=C=CN1C(=O)OC[C@H]1c1ccccc1)C=Cc1ccco1</smiles>

(P)-575: $\mathrm{n}=1$

(M)-575: $\mathrm{n}=1$

576: $\mathrm{n}=2, P: M=1: 1$

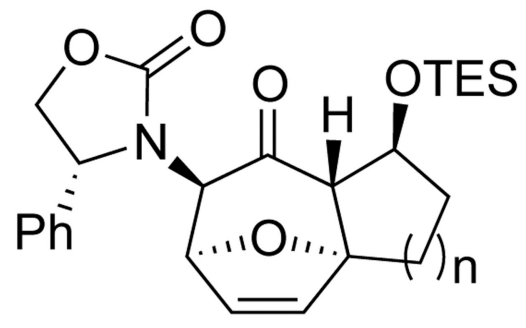

577: $\mathrm{n}=1,60 \%, d r$ 90:10 578: $\mathrm{n}=1,75 \%, d r$ 90:10 579: $\mathrm{n}=2,65 \%, d r 97: 3$

Scheme 159. 
<smiles>[R7]C=C(C=C)N1C[R]([R])COC1=O</smiles><smiles>C=C/C(=C\c1ccccc1)N1CCOC1=O</smiles>

581a: $71 \%$ 6:1 $E / Z(A)$<smiles>C=C/C(=C\P=[In])N1C(=O)OC[C@H]1Br</smiles>

581b:

$$
\begin{aligned}
& 77 \%,>20: 1 E / Z(A) \\
& 87 \%,>20: 1 E / Z(B)
\end{aligned}
$$<smiles>C=CC(=C)N1C(=O)OC[C@H]1Br</smiles>

581c: $69 \%(A)$<smiles>C=C/C(=C\c1ccccc1)N(Cc1ccccc1)C(=O)OC(C)(C)C</smiles>

\section{1d:}

$45 \%,>20: 1 E / Z(\mathrm{~A})$ $61 \%,>20: 1 E / Z(B)$

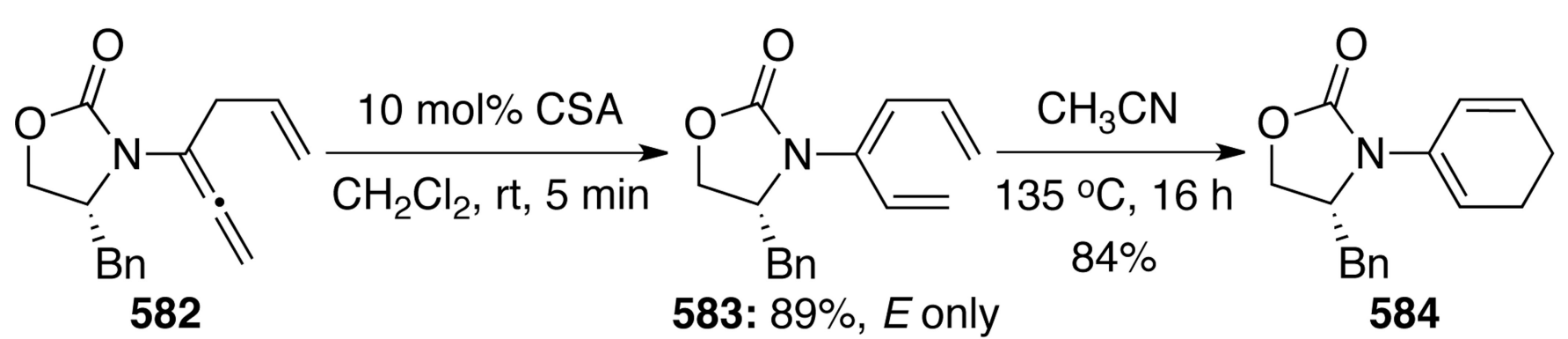
$\mathrm{CH}_{3} \mathrm{CN}, 135^{\circ} \mathrm{C}, 16 \mathrm{~h}$ $43 \%$

Scheme 160. 
<smiles></smiles>

585

586<smiles>[10B]OC(=O)N(Br)/C(C=C)=C/C=C\C</smiles>

586a: $86 \%$

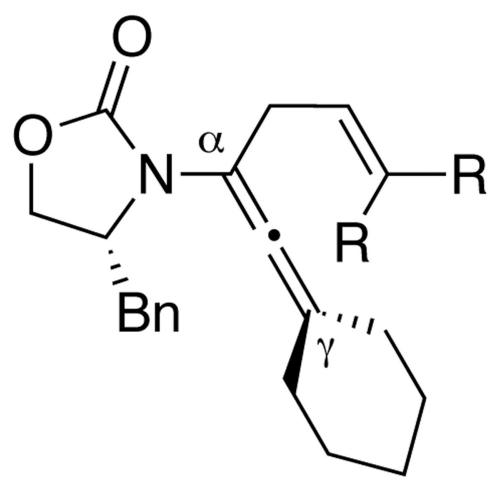

587a: $\mathrm{R}=\mathrm{H}$

587b: $R=M e$

Scheme 161.<smiles>C=C/C(=C\C=C(C)C)N1C(=O)OC[C@@H]1Br</smiles>

586b: $89 \%$

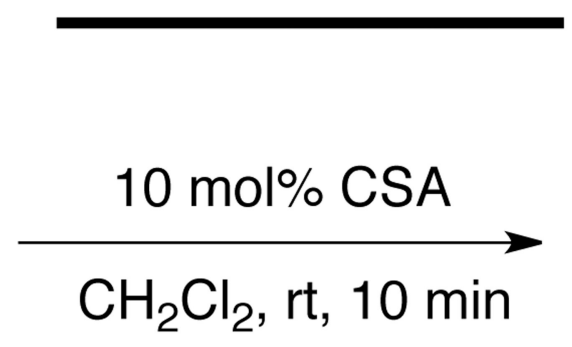

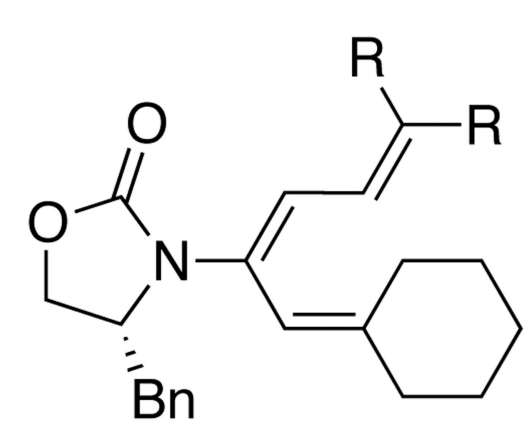

588a: $\mathrm{R}=\mathrm{H}[68 \%]$ 588b: $\mathrm{R}=\mathrm{Me}[80 \%]$ 


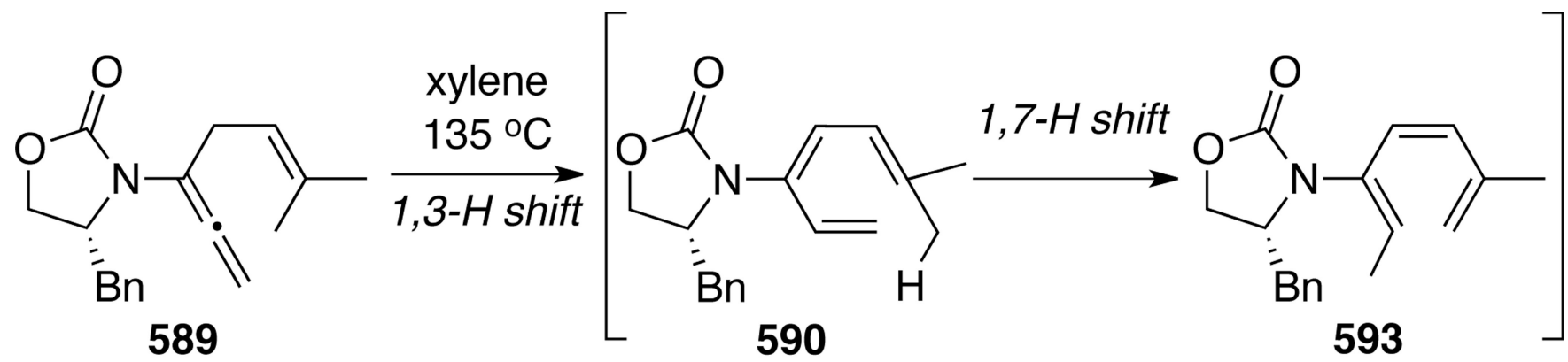

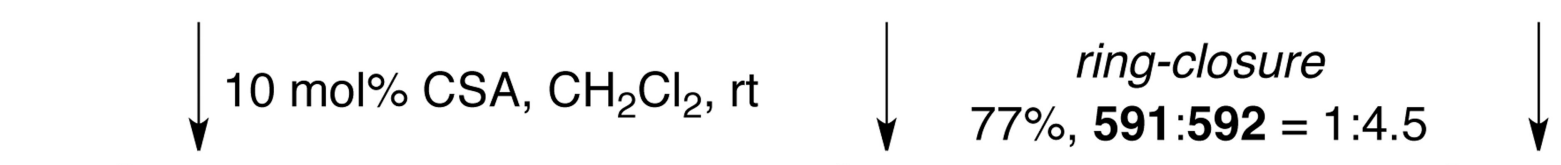

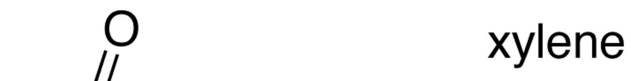<smiles>C=C/C=C(\C=C)N1C(=C)OC[C@@H]1Br</smiles>

590

591<smiles>CC1=CC=C(N2C(=O)OC[C@H]2Br)[C@H](C)C1</smiles>

Scheme 162. 
<smiles>[R]C=CCOCC=C([Z])CC(=C=C)N1C(=O)OC[C@H]1Br</smiles>

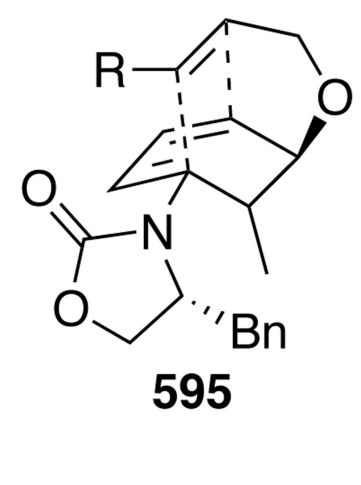

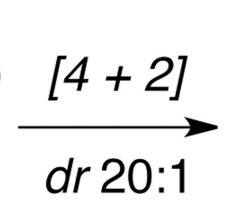<smiles>[R]C1C2C=CC3C1CO[C@@H]3C(C)C2N1C(=O)OC[C@H]1Br</smiles>
596a: $\mathrm{R}=\mathrm{H}$ [55\%] 596b: $\mathrm{R}=\mathrm{Ph}[48 \%]$

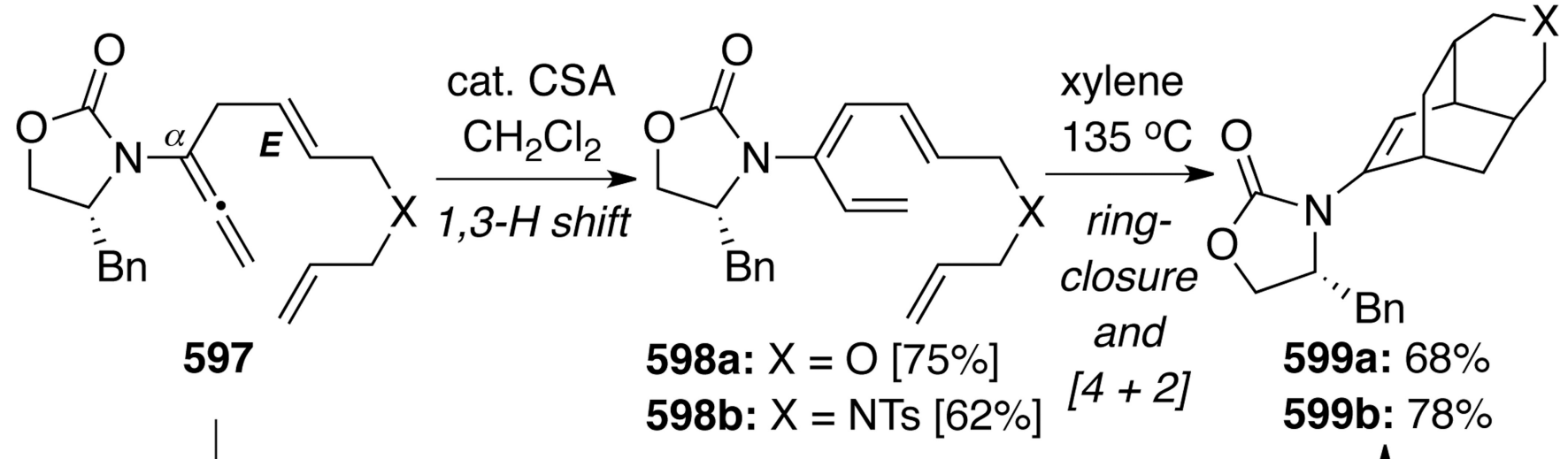

xylene, 135 ○ $\mathrm{C}: \mathrm{X}=\mathrm{O}$ [52\%]; X = NTs [62\%]

Scheme 163. 
<smiles>[R2]C=C(C([Y])=C)N1C[R7]([R10])([H])COC1=O</smiles><smiles>[R]CC(C(=C)C)=[N+](C[R7])C(=O)OC</smiles><smiles>C=C(Br)/C(=C\P=[In])N1C(=O)OC[C@H]1Br</smiles>
601a: $95 \%$<smiles>C=C(Br)/C(=C\C=C\C[OH+])N1C(=O)OC[C@H]1Br</smiles>

601c: $69 \%$<smiles>C=C(I)/C(=C\C=C\CN([13CH3])c1ccccc1)N1C(=O)OC[C@H]1Br</smiles>

601d: $96 \%$<smiles>C=C(Br)/C(=C\C=C\c1ccccc1)N1C(=O)OC[C@H]1Br</smiles>

601b: $87 \%$<smiles>C=C(Br)/C(=C\C1=CCCCC1)N1C(=O)OC[C@H]1Br</smiles>

601e: $42 \%$ 
<smiles>[Y]C(=C)/C(=C\C=C([R2])C)N1C[R7]([H])COC1=O</smiles>
603 604<smiles>O=C1OC[C@@H](Br)N1C1=C(Br)C[C@@H](P)C=C1</smiles><smiles>O=C1OC[C@@H](Br)N1C1=C(Br)C[C@@H](CO[Se])C=C1</smiles>
604a: 95\%, dr 90:10 604b: $79 \%$, dr 88:12<smiles>O=C1OC[C@@H](Br)N1C1=C(I)C[C@@H](CN(P)[As])C=C1</smiles>

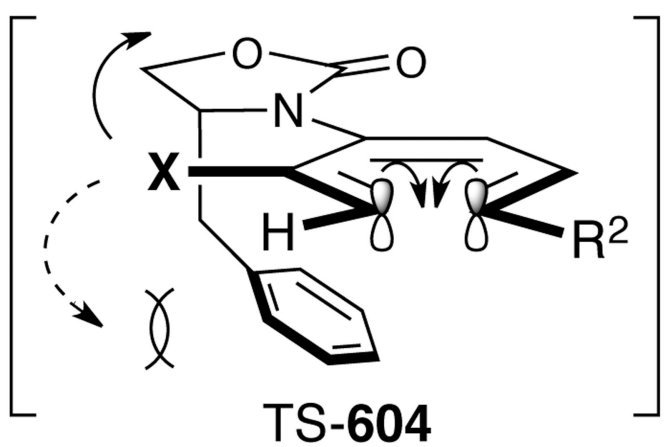

Scheme 165. 


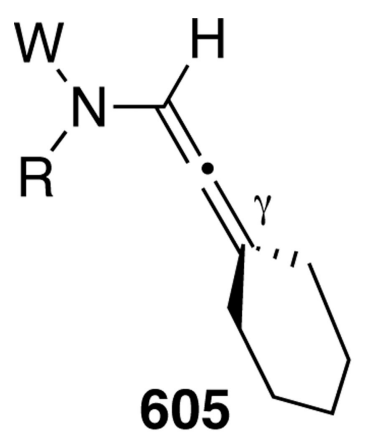

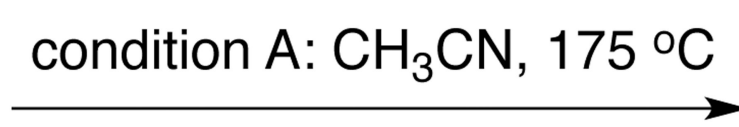

condition B: 10 mol\% CSA $\mathrm{CH}_{2} \mathrm{Cl}_{2}, \mathrm{rt}$

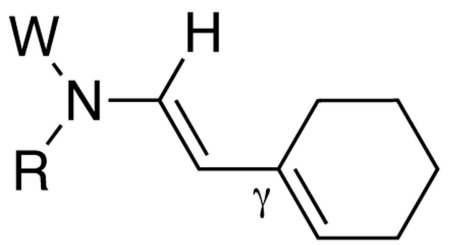

606a: $\mathrm{W}=\mathrm{Ac}, \mathrm{R}=\mathrm{Ph}$ [95\% (A), 90\% (B)] 606b: $\mathrm{W}=\mathrm{Ts}, \mathrm{R}=\mathrm{Bn}$ [96\% (A), 97\% (B)]

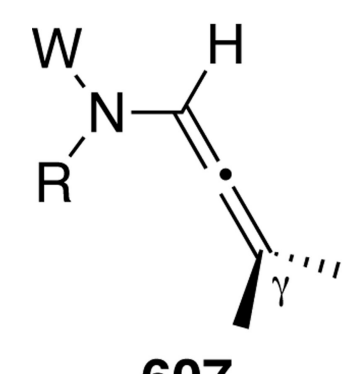

607 condition $\mathrm{A}: \mathrm{CH}_{3} \mathrm{CN}, 135-175^{\circ} \mathrm{C}$

condition B: 10 mol\% CSA

$\mathrm{CH}_{2} \mathrm{Cl}_{2}$, rt

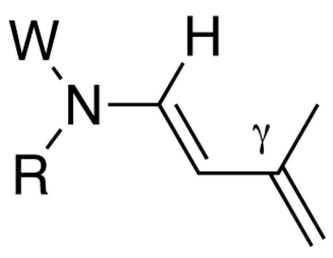

608a: $W=A c, R=P h$ [46\% (A), 97\% (B)] 608b: $W=T s, R=B n$ $[77 \%(A), 99 \%(B)]$

Scheme 166. 


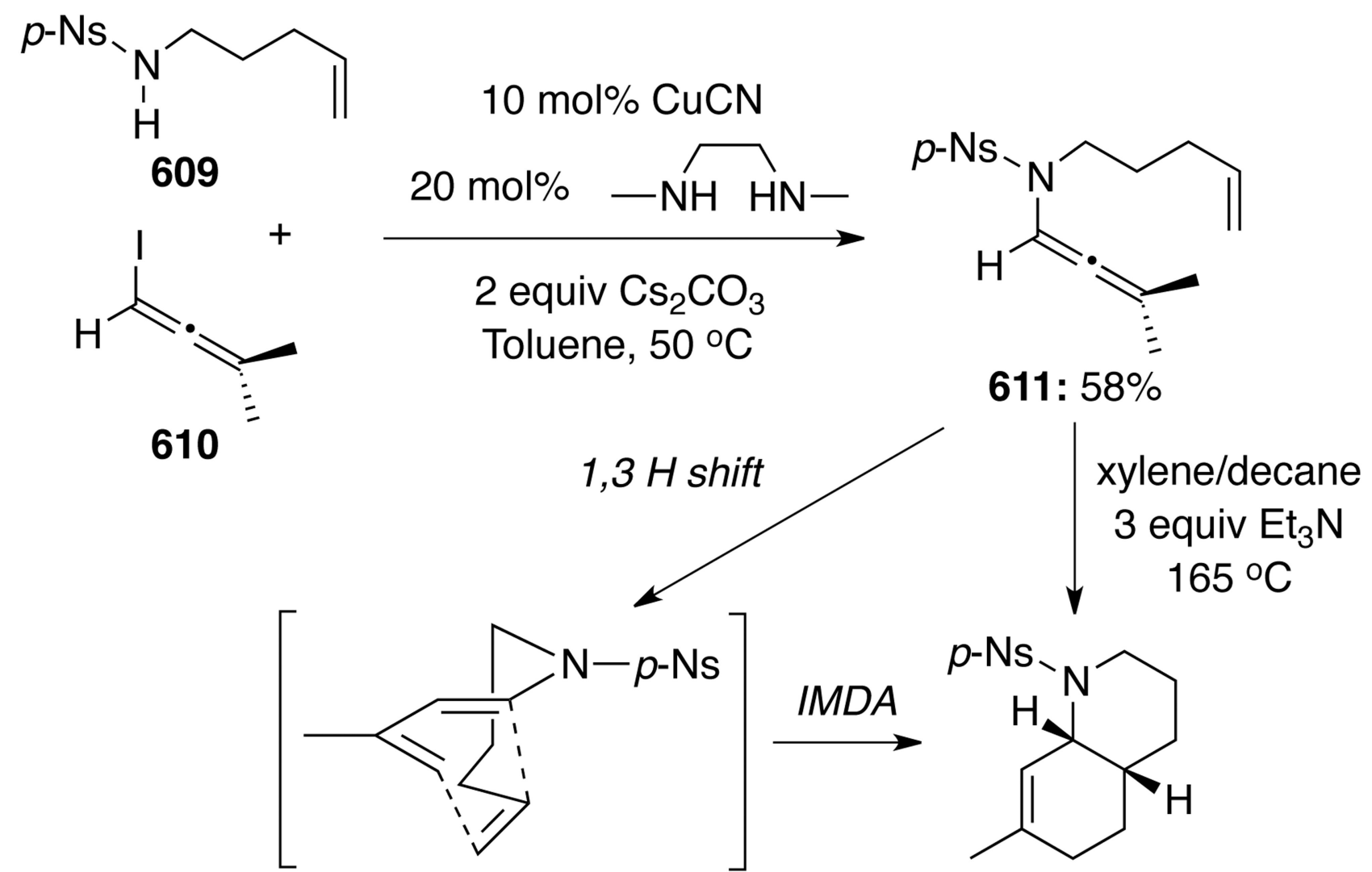

613: endo approach

612a: $76 \%$<smiles>O=[SH](=O)N1CC[C@H]2CCC=C[C@H]21</smiles>

612b: $40 \%$<smiles>O=S(=O)(O)N1CCC[C@H]2C[C@@H]3CCCCC3=C[C@H]21</smiles><smiles>C1=C2CCCC[C@H]2C[C@H]2Cc3ccccc3N(C3CCCC3)[C@H]12</smiles>
$d r 10: 1$ Scheme 167. 


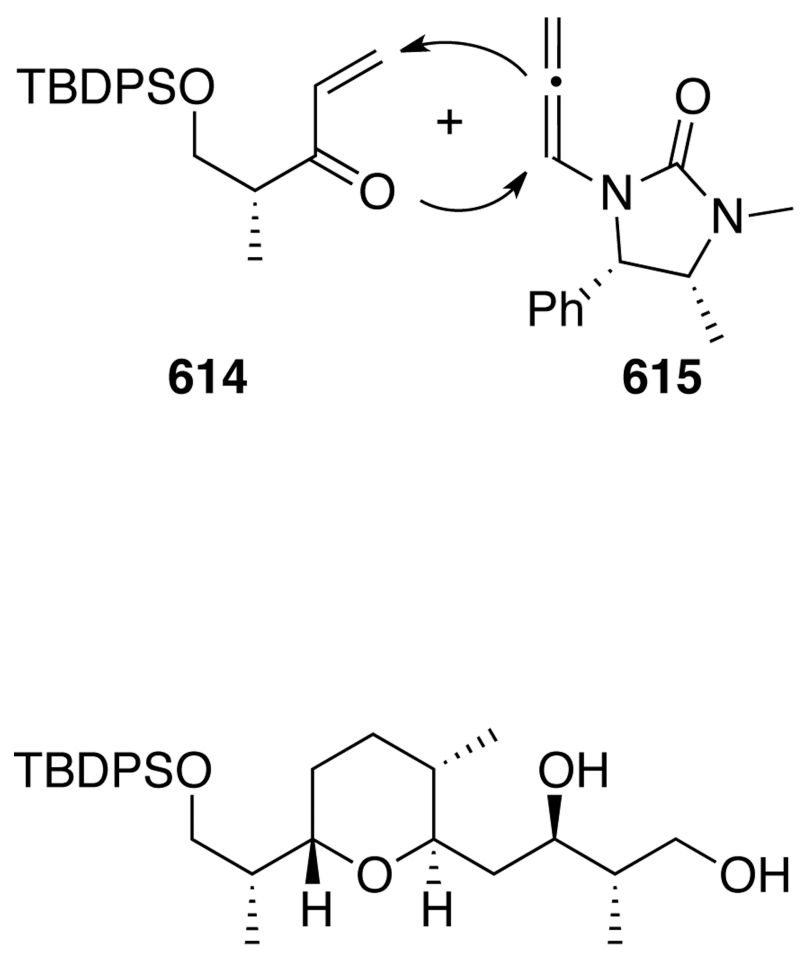

618: Miyashita's intermediate

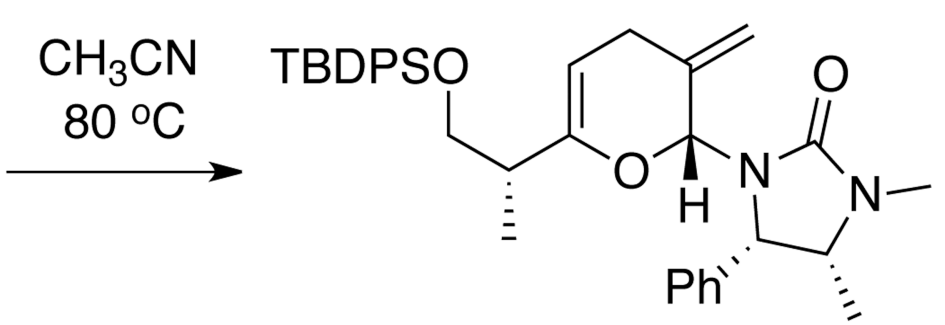

616: $54 \% ; d r>95: 5$

1) $\mathrm{H}_{2}$ (1500 psi), Pt/Alumina 2) $\mathrm{SnBr}_{4}, \mathrm{CH}_{2} \mathrm{Cl}_{2}$

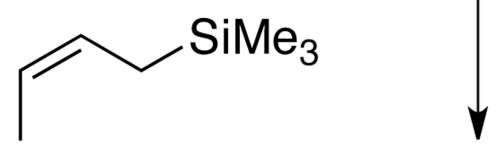<smiles>CCCC(C)/C=C(\C)[C@@H](O)[C@@H](C)/C=C/CC[C@H](O)[C@@H](C)[C@H](O)[C@@H](C)[C@@H](O)C[C@H]1O[C@@H]([C@@H](C)C(=O)O)CC[C@H]1C</smiles>

619: (+)-zincophorin

Scheme 168. 


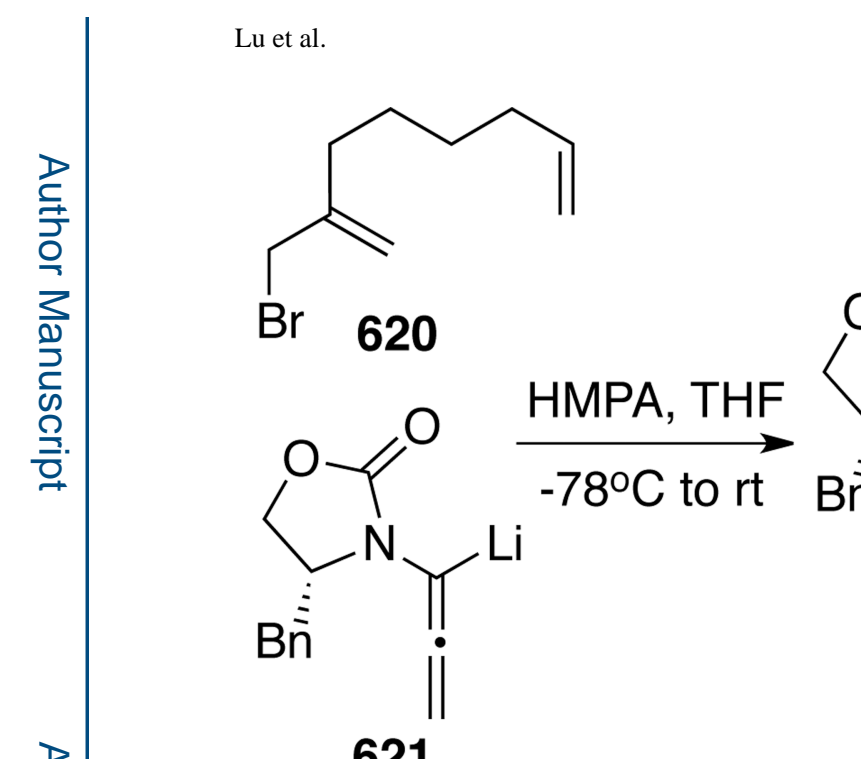

621

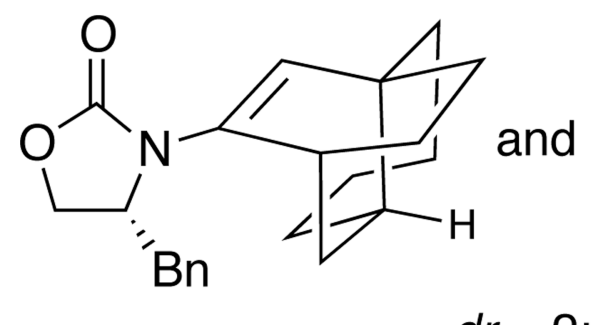

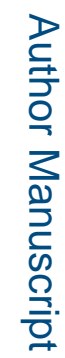

626: endo<smiles>C=C=C(CC(=C)CCCCC=C)N1C(=O)OC[C@H]1Br</smiles>

622: $66 \%$

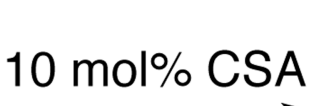
$\mathrm{CH}_{2} \mathrm{Cl}_{2}, \mathrm{rt} \underset{\mathrm{Bn}}{\stackrel{\text { 三 }}{\longrightarrow}}$<smiles>C=CCCCCC(=C)/C=C(\C=C)N1C(=O)OC[C@H]1Br</smiles>

623: $83 \%$

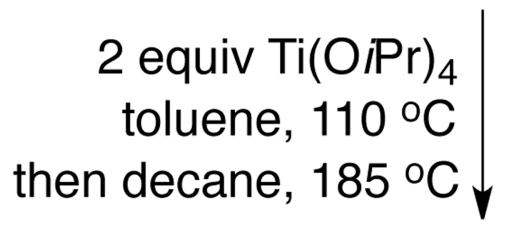

$$
\text { then decane, } 185 \text { o }
$$<smiles>O=C1OC[C@@H](Br)N1C1=CC2CCCC1CC2</smiles>

625: endo-b

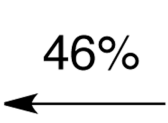<smiles>C=CCCCCC1=CC(N2C(=O)OC[C@H]2Br)=CCC1</smiles>

624: $95 \%$ Scheme 169. 

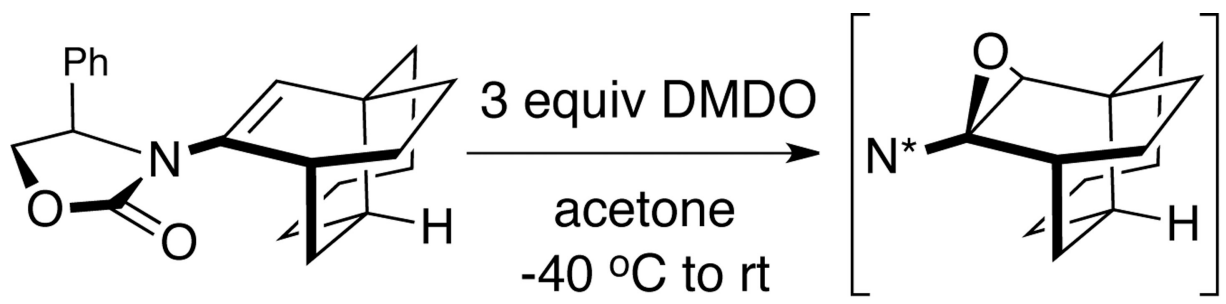

$10 \mathrm{~mol} \% \mathrm{p}-\mathrm{TsOH}$ acetone/ $/ \mathrm{H}_{2} \mathrm{O}$ [3:1], rt 627: $[d r=2: 1]$

628: $\mathrm{N}^{\star}=$ chiral amide

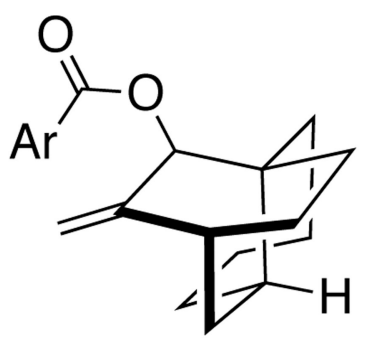
631: $71 \%$ $\mathrm{Ar}=2,4$-dinitro-Ph

$\mathrm{ArCO}_{2} \mathrm{H}$ DCC, DMAP<smiles>CCCO</smiles>
$\mathrm{CH}_{2} \mathrm{Cl}_{2}, \mathrm{rt}$
Scheme 170.
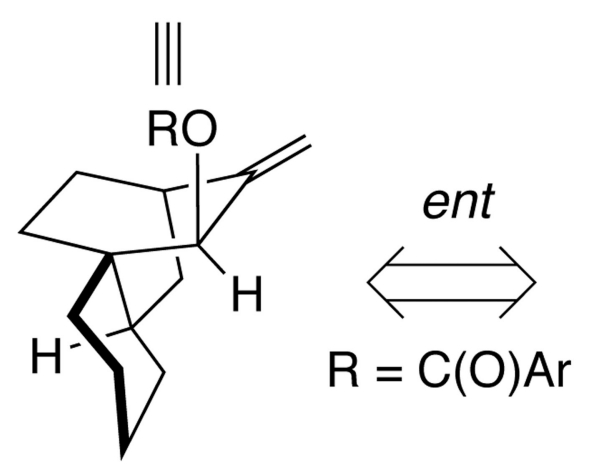

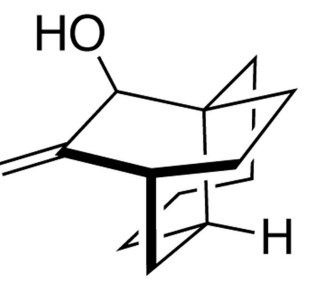

630: $73 \%$
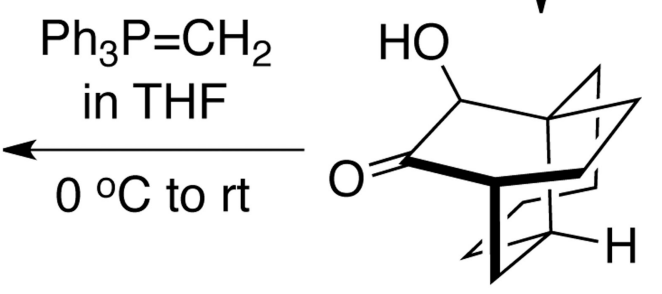

629: $85 \%$ overall
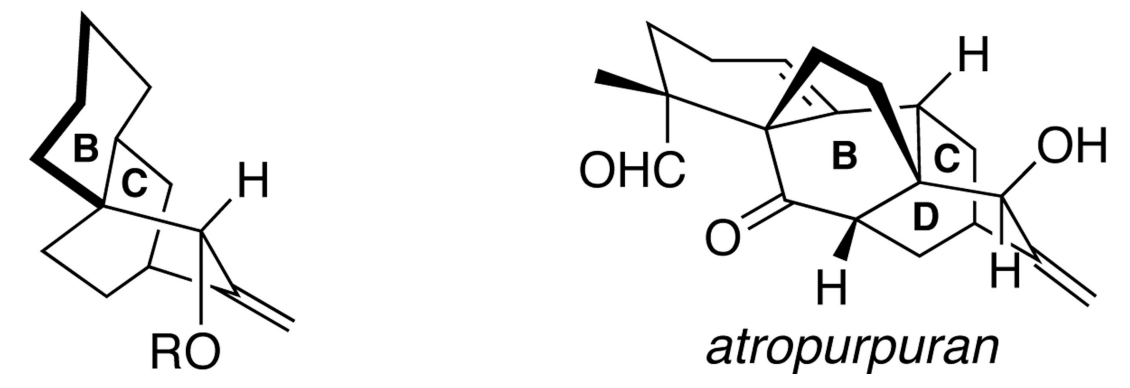


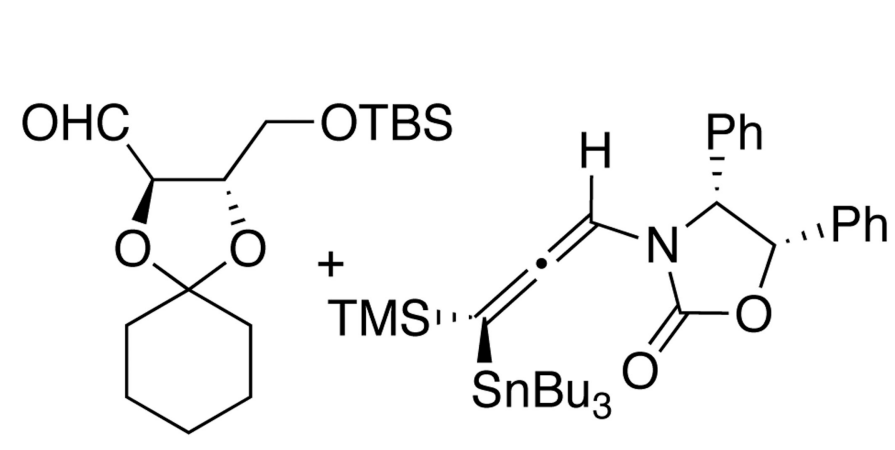

632

633

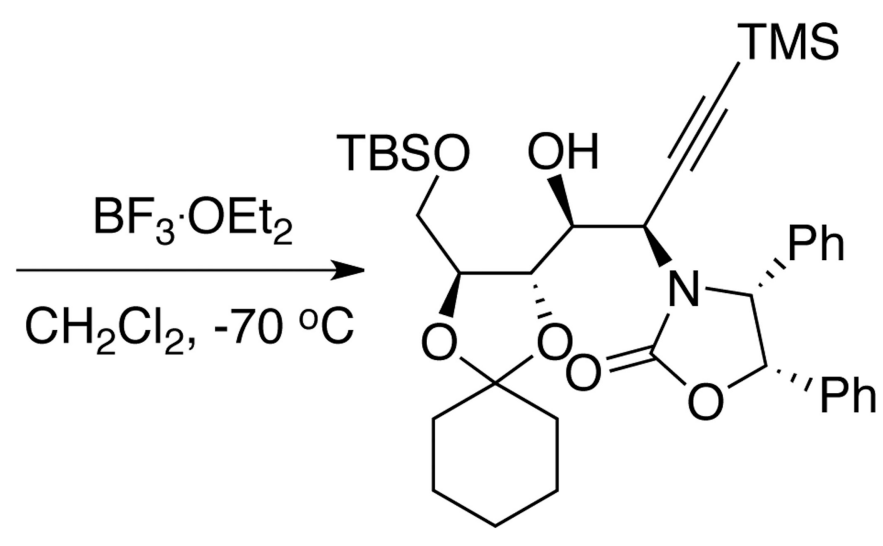

637- $\mathrm{HCl}:$ 1-deoxy-D-galacto-

1) hydroboration/oxidation

2) lactonization

3) auxiliary cleavage

4) deprotection homonojirimycin hydrochloride salt<smiles>OCC[C@H]1NC[C@@H](O)[C@H](O)[C@@H]1O</smiles>

$637-\mathrm{HCl}$
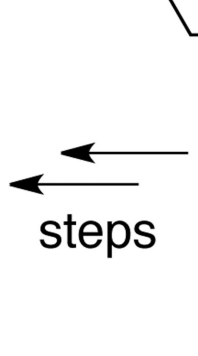

Scheme 171. 
<smiles>C=C=CN(CCc1ccc(OC)c(OC)c1)C(=O)c1ccccc1I</smiles>

638

methylene protoberberine<smiles>C=C1c2ccccc2C(=O)N2CCc3cc(OC)c(OC)cc3C12</smiles>

641: $70 \%$<smiles>C=CC=[N+](CCc1ccc(OC)c(OC)c1)C(=O)c1ccccc1I</smiles>

639<smiles>C=CC1c2cc(OC)c(OC)cc2CCN1C(=O)c1ccccc1I</smiles>

640: $78 \%$

Scheme 172. 


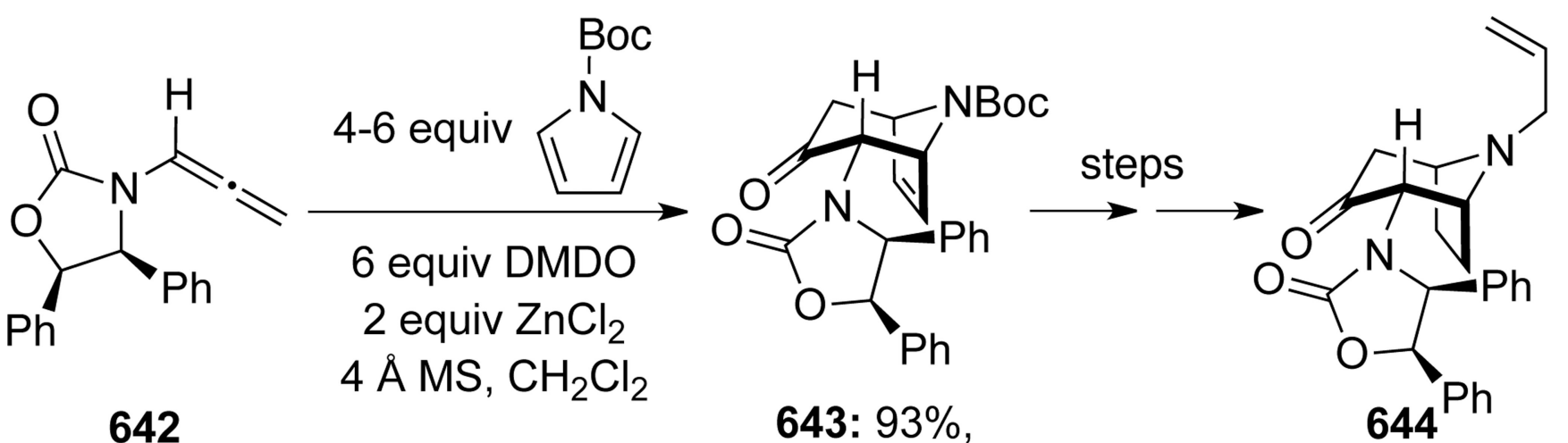

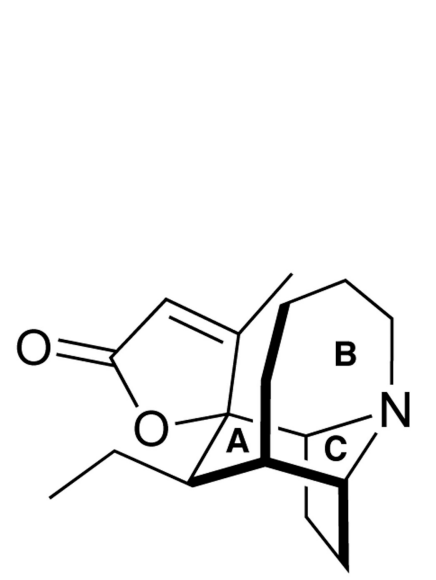

parvineostemonine

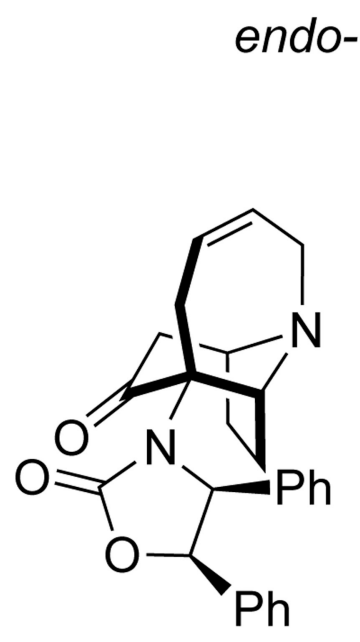

646: $36 \%$
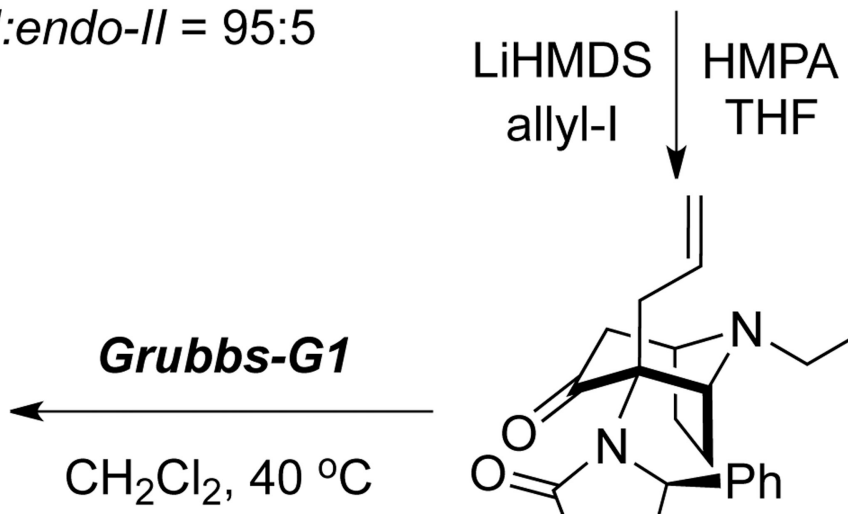

Scheme 173. 
<smiles>CC(C#CN1CCOC1=O)OC(=O)C[Al]CC(=O)OC(=CC(C)c1c[nH]c2ccccc12)N1CCOC1=O</smiles><smiles>CC=C(C)C(OC(=O)CBr)=C1OCCN1C(=O)O</smiles>
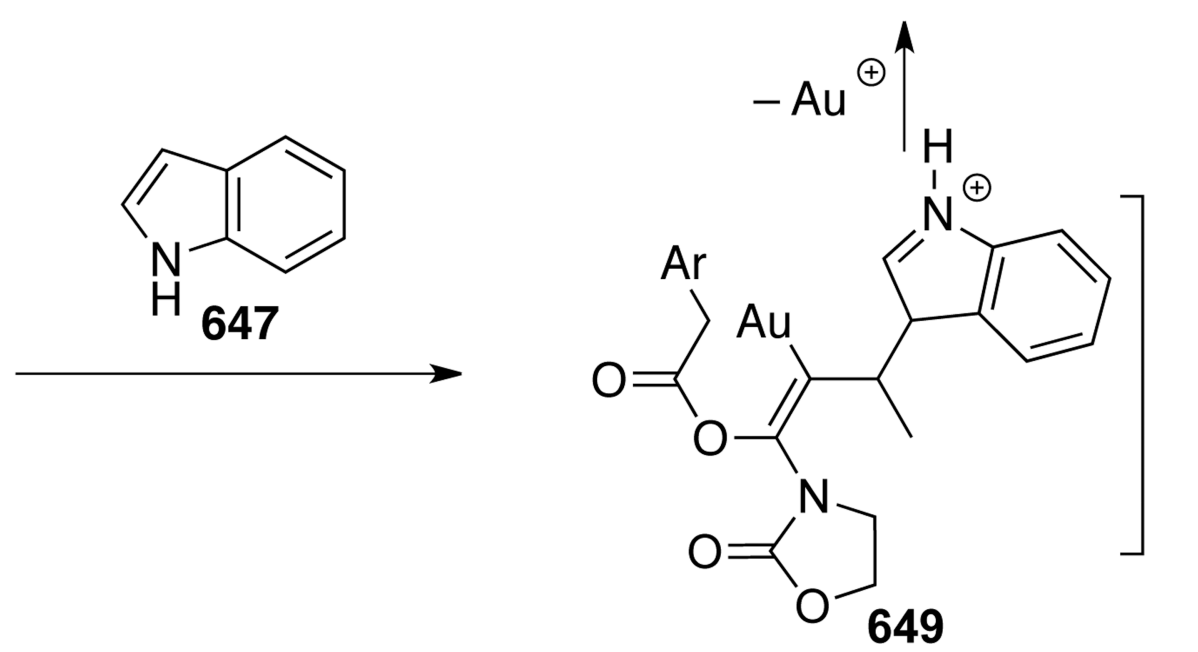

Scheme 174. 
<smiles>C=C=CN1C(=O)c2ccccc2C1=O</smiles>

\section{Method A: $1 \mathrm{~mol}^{\circ} \mathrm{Rh}_{2}(\mathrm{OPiv})_{4}$ \\ $\mathrm{CH}_{2} \mathrm{Cl}_{2}, \mathrm{O}^{\circ} \mathrm{C}$ to $\mathrm{rt}$}

Or: Method B: 1 mol\% $\mathrm{Rh}_{2}(S-I B A Z)_{4}$ $\mathrm{PhH} /$ Mesitylene, $0{ }^{\circ} \mathrm{C}$ to rt<smiles>N#CC(=N[R6](=O)(=O)c1ccccc1)C(=O)O[AsH3]</smiles><smiles>CCOC(=O)[C@H](C#N)CC</smiles><smiles>CC(C)(C)OC(=O)[C@]1(C#N)C/C1=C\N1C(=O)c2ccccc2C1=O</smiles>

653: $95 \%, E / Z>97: 3$ (Method A); 48\%, E/Z97:3, 90\% ee (Method B)

Scheme 175. 